\title{
Brine Contamination to Aquatic Resources from Oil and Gas Development in the Williston Basin, United States
}

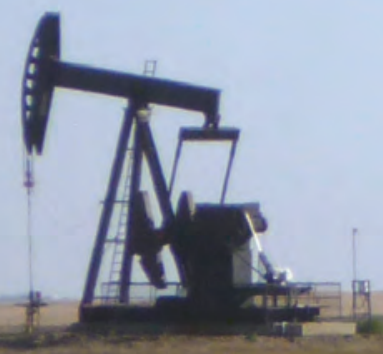

Scientific Investigations Report 2014-5017

U.S. Department of the Interior U.S. Geological Survey 
Covers. Wetland and nearby oil well in Sheridan County, Montana, September 2011. Photographs by Tara Chesley-Preston, U.S. Geological Survey. 


\section{Brine Contamination to Aquatic Resources from Oil and Gas Development in the Williston Basin, United States}

Edited by Robert A. Gleason and Brian A. Tangen

Contributions by Tara L. Chesley-Preston, James L. Coleman, Robert A. Gleason, Seth S. Haines, Karen E. Jenni, Timothy L. Nieman, Zell E. Peterman, Max Post van der Burg, Todd M. Preston, Bruce D. Smith, Brian A. Tangen, and Joanna N. Thamke

Volume comprises chapters A, B, C, and D

Scientific Investigations Report 2014-5017 


\title{
U.S. Department of the Interior SALLY JEWELL, Secretary
}

\section{U.S. Geological Survey Suzette M. Kimball, Acting Director}

\author{
U.S. Geological Survey, Reston, Virginia: 2014
}

For more information on the USGS — the Federal source for science about the Earth, its natural and living resources, natural hazards, and the environment, visit http://www.usgs.gov or call 1-888-ASK-USGS.

For an overview of USGS information products, including maps, imagery, and publications, visit http://www.usgs.gov/pubprod

To order this and other USGS information products, visit http://store.usgs.gov

Any use of trade, firm, or product names is for descriptive purposes only and does not imply endorsement by the U.S. Government.

Although this information product, for the most part, is in the public domain, it also may contain copyrighted materials as noted in the text. Permission to reproduce copyrighted items must be secured from the copyright owner.

Suggested citation:

Gleason, R.A., and Tangen, B.A., eds., 2014, Brine contamination to aquatic resources from oil and gas development in the Williston Basin, United States: U.S. Geological Survey Scientific Investigations Report 2014-5017, 127 p., http://dx.doi.org/10.3133/sir20145017.

ISSN 2328-031X (print)

ISSN 2328-0328 (online)

ISBN 978-1-4113-3782-4 


\section{Acknowledgments}

Funding for this work was provided by the U.S. Geological Survey.

The authors would like to thank Jon Reiten of the Montana Bureau of Mines and Geology and Mickey McCall of the Sheridan County Conservation District for assisting in the collection of water samples and geophysical data and all of the State agency personnel who assisted in the development of the spatial databases. We also thank the attendees of the decision analysis workshop for contributing their time and expertise. Thanks are extended to the following U.S. Fish and Wildlife Service personnel for providing information relating to conservation easements and piping plover critical habitat: Sue Kvas, Chuck Loesch, Will Meeks, Connie Mueller, and Neal Niemuth, as well as Karen Nelson and David Rouse for assistance in collecting geophysical data. Also, special thanks to Jerry Rodriquez and the staff at Medicine Lake National Wildlife Refuge for providing site access and accommodations for field staff. 



\section{Volume Contents}

Brine Contamination to Aquatic Resources from Oil and Gas Development in the

Williston Basin, United States....

by Tara L. Chesley-Preston, James L. Coleman, Robert A. Gleason, Seth S. Haines, Karen E. Jenni, Timothy L. Nieman, Zell E. Peterman, Max Post van der Burg, Todd M. Preston, Bruce D. Smith, Brian A. Tangen, and Joanna N. Thamke

A. Oil and Gas Production, Aquatic Resources, and Brine Contamination in the Williston Basin, United States.

by Brian A. Tangen, Seth S. Haines, Todd M. Preston, and

Joanna N. Thamke

B. Brine Contamination of Prairie Pothole Environments at Three Study Sites in the Williston Basin, United States

by Todd M. Preston, Joanna N. Thamke, Bruce D. Smith, and

Zell E. Peterman

C. Spatial Characterization of Oil and Gas Development and Aquatic Resources in the Williston Basin, United States.

by Brian A. Tangen, Robert A. Gleason, and Tara L. Chesley-Preston

D. Charting a Course Forward-Identifying Research and Decisionmaking

Priorities in the Williston Basin, United States..

by Max Post van der Burg, Karen E. Jenni, Timothy L. Nieman, and James L. Coleman 


\section{Conversion Factors}

SI to Inch/Pound

\begin{tabular}{|c|c|c|}
\hline Multiply & By & To obtain \\
\hline \multicolumn{3}{|c|}{ Length } \\
\hline meter $(\mathrm{m})$ & 3.281 & foot $(\mathrm{ft})$ \\
\hline kilometer (km) & 0.6214 & mile (mi) \\
\hline \multicolumn{3}{|c|}{ Area } \\
\hline square kilometer $\left(\mathrm{km}^{2}\right)$ & 247.1 & acre \\
\hline square kilometer $\left(\mathrm{km}^{2}\right)$ & 0.3861 & square mile $\left(\mathrm{mi}^{2}\right)$ \\
\hline hectare (ha) & 0.003861 & square mile $\left(\mathrm{mi}^{2}\right)$ \\
\hline \multicolumn{3}{|c|}{ Volume } \\
\hline cubic meter $\left(\mathrm{m}^{3}\right)$ & 6.290 & barrel (petroleum, 1 barrel $=42$ gal) \\
\hline liter $(\mathrm{L})$ & 0.2642 & gallon (gal) \\
\hline cubic meter $\left(\mathrm{m}^{3}\right)$ & 264.2 & gallon (gal) \\
\hline cubic meter $\left(\mathrm{m}^{3}\right)$ & 0.0002642 & million gallons (Mgal) \\
\hline cubic meter $\left(\mathrm{m}^{3}\right)$ & 35.31 & cubic foot $\left(\mathrm{ft}^{3}\right)$ \\
\hline \multicolumn{3}{|c|}{ Flow rate } \\
\hline meter per second $(\mathrm{m} / \mathrm{s})$ & 3.281 & foot per second (ft/s) \\
\hline meter per year $(\mathrm{m} / \mathrm{yr})$ & 3.281 & foot per year (ft/yr) \\
\hline \multicolumn{3}{|c|}{ Mass } \\
\hline gram $(\mathrm{g})$ & 0.03527 & ounce, avoirdupois (oz) \\
\hline megagram $(\mathrm{Mg})$ & 1.102 & ton, short $(2,000 \mathrm{lb})$ \\
\hline
\end{tabular}

Temperature in degrees Celsius $\left({ }^{\circ} \mathrm{C}\right)$ may be converted to degrees Fahrenheit $\left({ }^{\circ} \mathrm{F}\right)$ as follows:

${ }^{\circ} \mathrm{F}=\left(1.8 x^{\circ} \mathrm{C}\right)+32$

Specific conductance is given in microsiemens per centimeter at 25 degrees Celsius $(\mu \mathrm{S} / \mathrm{cm}$ at $\left.25^{\circ} \mathrm{C}\right)$.

Apparent conductivity of the soil water matrix is given in millisiemens per meter $(\mathrm{mS} / \mathrm{m})$.

Concentrations of chemical constituents in water are given either in milligrams per liter (mg/L) or micrograms per liter ( $\mu \mathrm{g} / \mathrm{L})$. 


\title{
Brine Contamination to Aquatic Resources from Oil and Gas Development in the Williston Basin, United States
}

\author{
Edited by Robert A. Gleason and Brian A. Tangen
}

\section{Executive Summary}

The Williston Basin, which includes parts of Montana, North Dakota, and South Dakota in the United States and the provinces of Manitoba and Saskatchewan in Canada, has been a leading domestic oil and gas producing region for more than one-half a century. Currently, there are renewed efforts to develop oil and gas resources from deep geologic formations, spurred by advances in recovery technologies and economic incentives associated with the price of oil. Domestic oil and gas production has many economic benefits and provides a means for the United States to fulfill a part of domestic energy demands; however, environmental hazards can be associated with this type of energy production in the Williston Basin, particularly to aquatic resources (surface water and shallow groundwater) by extremely saline water, or brine, which is produced with oil and gas. The primary source of concern is the migration of brine from buried reserve pits that were used to store produced water during recovery operations; however, there also are considerable risks of brine release from pipeline failures, poor infrastructure construction, and flow-back water from hydraulic fracturing associated with modern oilfield operations.

During 2008, a multidisciplinary (biology, geology, water) team of U.S. Geological Survey researchers was assembled to investigate potential energy production effects in the Williston Basin. Researchers from the U.S. Geological Survey participated in field tours and met with representatives from county, State, tribal, and Federal agencies to identify information needs and focus research objectives. Common questions from agency personnel, especially those from the U.S. Fish and Wildlife Service, were "are the brine plumes (plumes of brine-contaminated groundwater) from abandoned oil wells affecting wetlands on Waterfowl Production Areas and National Wildlife Refuges?" and "are newer wells related to Bakken and Three Forks development different than the older, abandoned wells (in terms of potential for affecting aquatic resources)?" Of special concern were the wetland habitats of the ecologically important Prairie Pothole Region, which overlays a part of the Williston Basin and is recognized for the production of a majority of North America's migratory waterfowl.
On the basis of the concerns raised by on-the-ground land managers, as well as findings from previous research, a comprehensive study was developed with the following goals: summarize existing information pertaining to oil and gas production and aquatic resources in the Williston Basin; assess brine plume migration from new and previously studied sites in the Prairie Pothole Region; perform a regional, spatial evaluation of oil and gas production activities and aquatic resources; assess the potential for brine contamination to wetlands and streams; and hold a decision analysis workshop with key stakeholders to discuss issues pertaining to oil and gas production and environmental effects and to identify information gaps and research needs.

This report represents an initial, multidisciplinary evaluation of measured and potential environmental effects associated with oil and gas production in the Williston Basin and Prairie Pothole Region. Throughout this report there are reviews of current knowledge, and discussions relating to data gaps and research needs. On the basis of the information presented, future research needs include: regional geophysical and water-quality assessments to establish baselines for current conditions and estimate the extent of previous brine contamination, investigations into the direct effects of brine to biotic communities, and evaluations to identify the most effective techniques to mitigate brine contamination.

\section{Principal Findings}

\section{Brine Contamination of Prairie Pothole Environments at Three Study Sites in the Williston Basin, United States}

Surface-water and shallow groundwater samples were collected and electromagnetic geophysical surveys were performed at three study sites in the Prairie Pothole Region to assess saline contamination from produced waters (brine) from nearby oil and gas production. Water-quality results indicated that 34 of the 48 samples were moderately or extremely contaminated with brine, and another 7 were potentially 
contaminated. Much of the salinity present in surface water and shallow groundwater during 2009 and 2010 at two of the study sites likely came from buried reserve pits that were installed in the mid- to late-1960s, indicating that contamination can persist for at least four to five decades. Geophysical surveys performed at the three study sites measured elevated apparent conductivity near most of the oilfield facilities. Analysis of groundwater samples confirmed that areas of elevated apparent conductivity were areas of brine-contaminated groundwater. Therefore, interpretation of electromagnetic geophysical data in conjunction with water-quality data provides an effective method to identify brine-contaminated groundwater in the Prairie Pothole Region.

The lateral migration of brine in groundwater appears to be controlled, in part, by the type of near-surface sediments, with observed migration distances of at least 600 and 800 meters in glacial outwash deposits and at least 400 meters in glacial till. The vertical migration of brine in groundwater is also controlled by sediment type and is measurable with geophysical methods. Apparent conductivity decreased substantially with decreasing frequency (depth) where glacial outwash deposits overlie clay-rich, glacial till. No substantial change in apparent conductivity was observed as a function of frequency (depth) in the clay-rich glacial till deposits. Apparent conductivity values increased substantially with depth where silt and clay lacustrine deposits overlie clay-rich glacial till.

Strontium isotope data from samples of produced waters, surface water, and groundwater confirmed that the source of high salinity contamination at the three study sites is brine produced with hydrocarbons. Potential mechanisms for the release of brine in the Williston Basin include discharges from oil and gas wells, tank batteries, reserve pits, and pipelines, as well as illegal dumping.

\section{Spatial Characterization of Oil and Gas Development and Aquatic Resources in the Williston Basin, United States}

A spatial characterization of the Williston Basin and various county-level assessments of the distribution of aquatic resources and oil- and gas-related wells were performed using databases describing wells, wetlands and streams, and critical riparian habitats for a federally threatened bird species. The purpose of the county-level assessments was to identify areas within the Williston Basin that have the greatest likelihood of containing brine-affected aquatic resources. These assessments were founded on the premise that counties with the greatest numbers and densities of wells and aquatic resources would have a greater probability of containing wetlands and streams affected by brine than counties with fewer of these features. Further, counties with more wetlands and streams adjacent to, or in close proximity to, wells were identified. These proximity analyses were performed because aquatic resources in close proximity to oil and gas producing wells are more likely to be affected by brine because of soil and surficial geologic properties that have been shown to limit subsurface brine migration.

The overall spatial characterization identified more than 30,000 oil- and gas-related wells that were permitted and drilled from approximately 1901 to 2011 , nearly 30,000 square kilometers $\left(\mathrm{km}^{2}\right)$ of wetlands, and about 190,000 kilometers $(\mathrm{km})$ of streams within the boundaries of the Williston Basin and Bakken Formation. A majority of the wells were drilled after 1950 and are located primarily on privately owned lands in northeastern Montana and western North Dakota. A proximity analysis performed in the Prairie Pothole Region of the study area identified about 290,000 wetlands covering almost $1,800 \mathrm{~km}^{2}$, more than $7,000 \mathrm{~km}$ of streams, and nearly $80 \mathrm{~km}^{2}$ of piping plover (Charadrius melodus) critical habitat within $1.6 \mathrm{~km}$ of oil- and gas-related wells, an observed distance of subsurface brine migration over time through some coarsegrained glacial outwash soils. About one-third of all wetlands in the Prairie Pothole Region part of the Williston Basin are located within $1.6 \mathrm{~km}$ of oil and gas wells, demonstrating the considerable vulnerability of these aquatic resources to brine contamination in the region. Similar analyses were performed using only oil and gas wells completed prior to 1980, the approximate date when associated reserve pits were required to be lined. Additionally, a more focused proximity analysis identified greater than 1,200 oil and gas wells, greater than $80,000 \mathrm{~km}^{2}$ of wetlands, and nearly $3,000 \mathrm{~km}$ of streams on or adjacent to U.S. Fish and Wildlife Service lands in the Prairie Pothole Region part of the study area. Lastly, it was determined that a $1.6-\mathrm{km}$ radial buffer around wells intersected greater than 3,500 U.S. Fish and Wildlife Service conservation easement contracts in the Prairie Pothole Region of the Williston Basin.

This spatial characterization, along with information presented in chapter B of this report, lays the foundation for understanding the potential for past and current oil and gas production to affect the vast aquatic resources within the Williston Basin. With the county-level assessments, an initial step was taken towards identifying areas of the Williston Basin and Prairie Pothole Region with the greatest number of oil and gas wells and aquatic resources. This information can be used to focus monitoring efforts and scientific studies for assessing potential contamination of aquatic resources from oil and gas development. Further, the information provided in this report, along with the identification of important data gaps, can help guide future efforts to perform more formal risk assessments of oil and gas production to aquatic resources.

\section{Charting a Course Forward-Identifying Research and Decisionmaking Priorities in the Williston Basin, United States}

A formal decision analysis workshop was held in Bismarck, North Dakota, during April 2011. Although performed within the context of the work described in previous chapters of this report, the overarching goal of this workshop was to 
frame the issues surrounding natural resource management and conservation decisionmaking with regard to oil and gas development within the Williston Basin. This decision analysis framework provides a clearer understanding of the decision context and provides guidance on how future applied scientific studies will provide the most value to decisionmakers. Additionally, this framework will clarify means to effectively communicate information about oil and gas development to those decisionmakers.

This chapter outlines the process used to develop the decision analysis framework. During the workshop, participants completed a modeling exercise designed to illustrate how oil well siting decisions might affect wetland and agricultural resources. While this exercise was not intended to inform an actual decision, it did highlight a number of issues that need to be addressed in moving forward with a more detailed analysis. These issues include making sure that all relevant stakeholders are represented in the analysis, properly defining the scale and extent of the problem, and assessing the value of resolving critical uncertainties regarding effects of oil and gas development. Charting a clear course forward, using decision analysis tools, will provide direction for continuing studies about oil and gas development that are decision relevant within the Williston Basin. 



\section{Oil and Gas Production, Aquatic Resources, and Brine Contamination in the Williston Basin, United States}

By Brian A. Tangen, Seth S. Haines, Todd M. Preston, and Joanna N. Thamke

Chapter A of

Brine Contamination to Aquatic Resources from Oil and Gas Development in the Williston Basin, United States

Edited by Robert A. Gleason and Brian A. Tangen

Scientific Investigations Report 2014-5017 
Suggested citation:

Gleason, R.A., and Tangen, B.A., eds., 2014, Brine contamination to aquatic resources from oil and gas development in the Williston Basin, United States: U.S. Geological Survey Scientific Investigations Report 2014-5017, 127 p.,

http://dx.doi.org/10.3133/sir20145017.

Suggested citation for this chapter:

Tangen B.A., Haines, S.S., Preston, T.M. and Thamke, J.N., 2014, Oil and gas production, aquatic resources, and brine contamination in the Williston Basin, United States, chap. A of Gleason, R.A., and Tangen, B.A., eds., Brine contamination to aquatic resources from oil and gas development in the Williston Basin, United States: U.S. Geological Survey Scientific Investigations Report 2014-5017, p. 5-20. 


\section{Contents}

Synopsis .
Oil and Gas Production in the Williston Basin
Geology
Produced Waters
Aquatic Resources
Prairie Pothole Region
Brine Contamination
Ecological Effects of Oil and Gas Production
Remediation of Brine Contamination

\section{Figures}

A-1. Map showing the Williston Basin, Bakken Formation, and

Prairie Pothole Region 



\title{
Oil and Gas Production, Aquatic Resources, and Brine Contamination in the Williston Basin, United States
}

\author{
By Brian A. Tangen, ${ }^{1}$ Seth S. Haines, ${ }^{1}$ Todd M. Preston, ${ }^{2}$ and Joanna N. Thamke ${ }^{1}$
}

\section{Synopsis}

The Williston Basin is an intracratonic basin that underlies parts of Montana, North Dakota, and South Dakota in the United States, and Manitoba and Saskatchewan in Canada. The Williston Basin has been a top domestic oil-producing region since the 1960s. Recent oil and gas assessments have identified substantial reserves associated with the DevonianMississippian Bakken and underlying Devonian Three Forks Formations, and the region is currently in the midst of a major oil boom triggered by advances in oil and gas recovery technologies and high oil prices. Past research detailing contamination of surface waters and groundwater by produced waters (brine), in conjunction with observed increases in oil and gas development and spills of highly saline brine, has raised concerns about possible effects of oil and gas production to sensitive aquatic resources. The primary source of concern is the migration of brine from buried reserve pits that were used to store produced waters during recovery operations; however, there also are considerable risks of brine release from pipeline failures, poor infrastructure construction, and enhanced hydraulic connectivity between abandoned well bores and modern oil and gas operations from hydraulic fracturing.

Overlying the northeastern half of the Williston Basin is the Prairie Pothole Region (PPR), which includes critical wetland breeding and nesting habitats for a large proportion of North America's waterfowl. The PPR is most often recognized for its vast number of pothole wetlands, with water chemistry that is highly variable and often differs significantly from brines in terms of salinity and ionic composition. The plant and invertebrate communities of pothole wetlands, which are critical to the provisioning of various ecosystem services, can be sensitive to salinity levels as well as specific salts (Gleason and others, 2009), and there are concerns over the ecological effects of brine contamination to these systems; however, there has been very little research pertaining to the direct effects of brines to biotic communities, especially in the Williston Basin.

The United States has a long history of oil and gas production, and there are standard methods for the remediation of

\footnotetext{
${ }^{1}$ U.S. Geological Survey
}

${ }^{2}$ Parallel, Inc. brine-affected soils and groundwater, but there are no standard guidelines for remediating surface waters such as pothole wetlands. In addition to data gaps associated with the effects of brine to biotic communities, studies are needed to identify and evaluate remediation techniques for closed-basin surface waters such as pothole wetlands.

\section{Oil and Gas Production in the Williston Basin}

The Williston Basin Province has been the subject of numerous U.S. Geological Survey (USGS) oil and gas resource assessments in recent years (Anna and others, 2008; Pollastro and others, 2008b; Gaswirth and others, 2013), and detailed descriptions of the geology and hydrocarbon-producing formations are widely available (Sandberg, 1962; Peterson, 1995; Thamke and Craigg, 1997; Iampen and Rostron, 2000; Anna and others, 2008; Pollastro and others, 2008b; Anna and others, 2011; Gaswirth and others, 2013). The current oil development boom produces from the Bakken Formation and the underlying Three Forks Formation. The Bakken Formation is composed of shale and other rock types deposited during the Devonian and Mississippian periods and the USGS estimated that the portion of the Bakken Formation located in the United States (fig. A-1) contains 3,649 million barrels of oil (MMBO), 89 billion cubic meters $\left(\mathrm{m}^{3}\right)$ of gas $(\mathrm{BCMG})$, and 246 million barrels of natural gas liquids that are recoverable with existing technologies (Gaswirth and others, 2013). The Three Forks Formation is composed of Devonian dolostone, mudstone, and anhydrite. The portion located in the United States is estimated to contain 3,734 MMBO, $101 \mathrm{BCMG}$, and 281 million barrels of natural gas liquids (Gaswirth and others, 2013). Each of the aforementioned assessment quantities is the mean value of a probability distribution function that expresses the uncertainty inherent in the associated measurements and methods. These formations in the Williston Basin have been identified as one of the world's greatest potential oil and gas reserves, with estimated volumes comparable to those of many leading oil-producing nations (Durham, 2010).

Oil and gas production in the Williston Basin began prior to the 1920s with gas production in the Cedar Creek anticline 


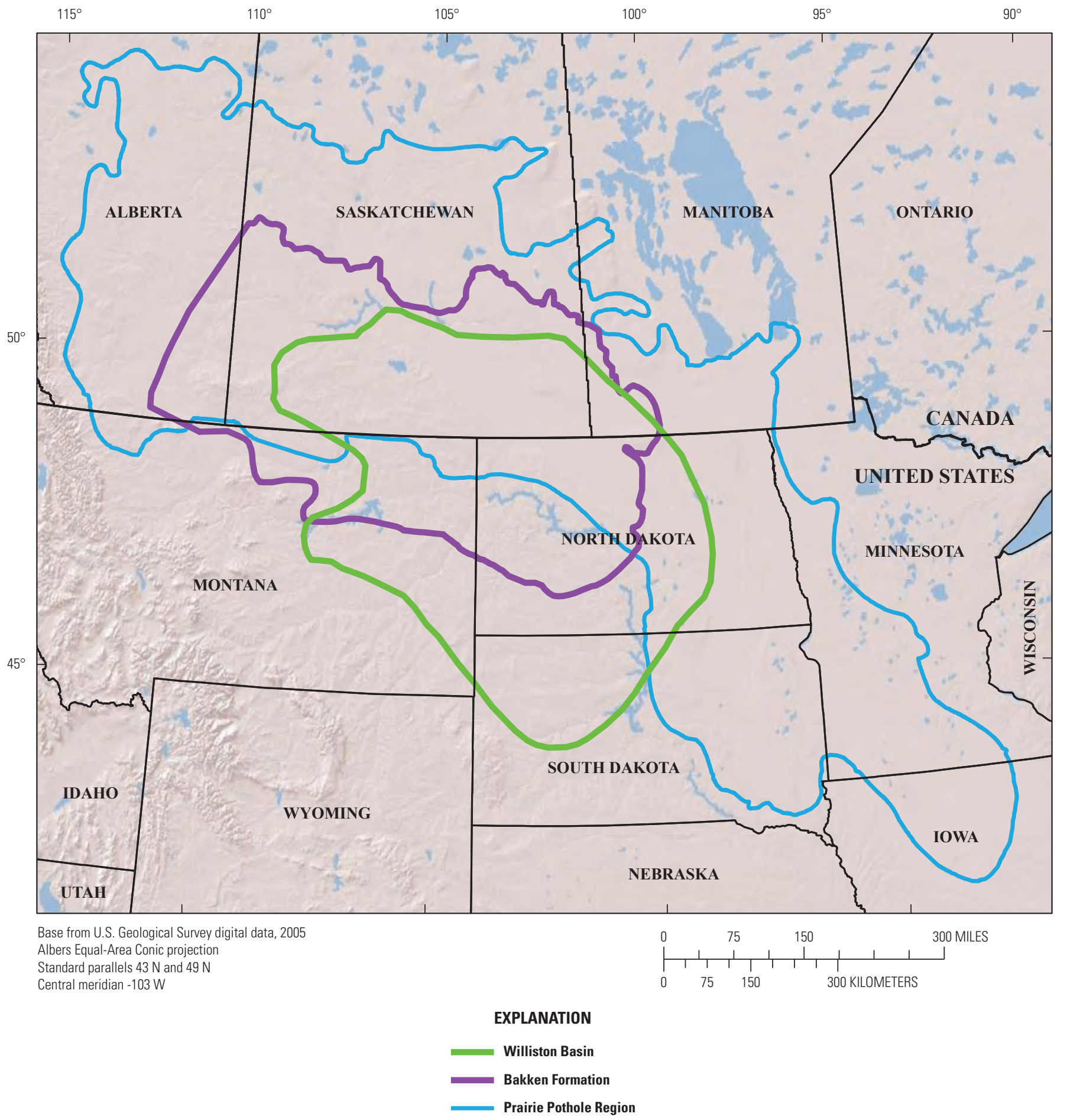

Figure A-1. The Williston Basin, Bakken Formation, and Prairie Pothole Region. 
area of Montana. Production increased substantially during the 1950s, with major oil discoveries throughout the basin (Gerhard and others, 1991; Peterson, 1995). These discoveries largely focused on the Mississippian Madison Group, though discoveries in the subsequent decades targeted other strata, and wells in the Williston Basin often produce oil and gas from several formations.

The Bakken Formation is generally considered the primary source rock for much of the hydrocarbons in the Williston Basin (Gerhard and others, 1991). In recent years, however, the Bakken Formation has become an exploration target, largely because of technological advances that make possible the extraction of large quantities of oil from this shale/sandstone formation. The development of high-precision horizontal drilling facilitates precise targeting of the sandstone middle member of the Bakken Formation along well bores that extend laterally up to approximately 3 kilometers $(\mathrm{km})$. These wells are productive because of the development of sophisticated methods for hydraulic fracturing that create permeable fracture networks in low-permeability rocks. Hydraulic fracturing is a procedure in which large quantities of water (commonly $3,785-37,850 \mathrm{~m}^{3}$ per well), sand, and a suite of chemicals are pumped under high pressure into the well bore. Hydraulic fracturing has been used for decades to improve well productivity, and contamination as a direct result has rarely been documented (DiGiulio and others, 2011; Papoulias and Velasco, 2013). Recent technological advances have vastly enhanced hydraulic fracturing's effectiveness and stimulated its widespread use, particularly in the production of oil and gas from formations that would otherwise be too impermeable for economic production.

Since 2001, the Bakken Formation has been the primary target for new wells drilled in the Williston Basin. The number of wells drilled has increased each year and at least 756 wells in the Bakken Formation were drilled in the North Dakota and Montana parts of the basin in 2010 (IHS Energy, 2011). It is anticipated that as many as 1,800 new wells per year over the next 10 years may be completed in the Bakken Formation in North Dakota (Schuh, 2010; Dyke and others, 2011). The rapid rate of development in the Williston Basin brings associated infrastructure such as roads, transportation pipelines, storage facilities, and well casings.

\section{Geology}

The Williston Basin is a structural sedimentary, intracratonic depression that formed in the North American craton during Ordovician time, likely because of interaction between two Archean shear systems (Gerhard and others, 1991; Peterson, 1995; Pollastro and others, 2008a). The Williston Basin underlies a large part of the northern Great Plains in the United States and extends into the Canadian provinces of Manitoba and Saskatchewan. In the United States, the Williston Basin occupies 249,703 square kilometers $\left(\mathrm{km}^{2}\right)$ and includes parts of Montana, North Dakota, and South Dakota (fig. A-1). The Canadian part of the basin covers $102,057 \mathrm{~km}^{2}$. The basin is generally dish-shaped (sedimentary rocks are thickest in the center and thinner toward the edges), with approximately 5,400 meters (m) of Cambrian through Tertiary strata (Gerhard and others, 1991). During the Paleozoic, deposition was largely dominated by carbonates; Mesozoic and Cenozoic deposition included considerably more clastic processes. Hydrocarbon generation and production has largely occurred in the deeper sedimentary strata, principally those that were deposited during the Paleozoic.

Overall, the Williston Basin is characterized by slight topographic relief (Peterson, 1995), with surficial sediments consisting mainly of materials transported by erosional processes such as glaciation and running water. The northeastern part of the basin is primarily a glacial till plain deposited during multiple Pleistocene glaciations, and the southwestern part is generally characterized by rolling plains, buttes, and badlands formed during the late Cretaceous and Tertiary periods (Eyles and Menzies, 1983; Bluemle, 2000). The glaciated northeastern part of the Williston Basin (PPR; fig. A-1) was the focus of the field studies described in Chapter B of this report; the following paragraphs provide an overview of the surficial geology of this focal area.

At the end of the Pleistocene, stagnation and ablation processes including melt-out, fluvial outwash, sediment slumping, and melt-water lake formation left behind a widespread ground moraine, which despite local variations in textural and mineralogical properties can be laterally homogenous over large geographic areas (Fullerton and others, 2004). The near-surface stratigraphy is a complex three-dimensional mixture of poorly sorted glacial till, fine-grained glaciolacustrine deposits, and coarse-grained glacial outwash channel deposits (Grisak and Cherry, 1975; Miall, 1983; Hendry, 1988; Fullerton and others, 2004). Glacial till consists primarily of clay-loam soils, outwash is characterized by sand and gravel, and lacustrine deposits are made up of silt, clay, and finegrained sand. Glacial outwash is relatively permeable, and till and lacustrine deposits often form aquitards, with secondary, vertical fractures accounting for most of the water movement (Grisak and Cherry, 1975; Reiten and Tischmak, 1993).

Lands covered by glacial sediments in this region are part of the PPR (fig. A-1). The landscape of the PPR is characterized by ice-decay features, hummocky topography, poorly developed drainages, and hundreds of thousands of depressional wetlands, which are often referred to as prairie potholes (see section, "Prairie Pothole Region"). Key physiographic regions of the PPR are the Missouri Coteau, Prairie Coteau, and Glaciated Plains (Bluemle, 2000; Gleason and Laubhan, 2008). The Glaciated Plains region was formed principally as a result of ground-moraine processes that created a gently rolling landscape, and the Missouri and Prairie Coteaux were formed by stagnant and dead-ice moraines that created a rugged area of closely spaced hills and depressions (Bluemle, 2000). The study sites described in Chapter B of this report were within the Missouri Coteau. 


\section{Produced Waters}

A major environmental challenge facing the energy industry is the handling and disposal of the substantial volume of brine that is produced with oil and gas during drilling and production (Wanty, 1997; Gorman, 1999). In general, brine is defined as having a total dissolved solids (TDS) concentration greater than 35,000 milligrams per liter (mg/L) (Kalkhoff, 1993); however, brine from the Williston Basin has some of the highest TDS levels (greater than $450,000 \mathrm{mg} / \mathrm{L}$ ) in the United States (Otton, 2006). Typically, the ratio of brine to oil and gas produced is at least 2 to 1 in traditional oil wells, but much larger proportions are common, and the fraction of brine produced increases as the amount of recoverable oil is reduced (Veil and others, 2004). For example, in 1993, oil production in the United States resulted in the extraction of 2.5 billion barrels of crude oil and 25 billion barrels of produced waters (Wanty, 1997). On the basis of these estimates, approximately 10 barrels of brine are produced per barrel of oil extracted using traditional methods. Consequently, production of brine is the major potential environmental contamination hazard associated with oil and gas production within the Williston Basin.

Disposal methods of brine in the United States have varied historically. Prior to the 1960s and 1970s, discharge of brine to streams, oceans, and unlined reserve or evaporation pits was unregulated, resulting in both onsite and offsite contamination of surface waters and groundwater throughout the United States (McMillion, 1965; Baker and Brendecke, 1983; Murphy and others, 1988; Kalkhoff, 1993; Gorman, 1999). Similarly, previous studies in the Williston Basin have identified brine contamination of surface waters (Reiten and Tischmak, 1993; Thamke and Craigg, 1997; Nelson, 2006; Rouse and others, 2013), soils (Lang and Doll, 1983; Beal and others, 1987; Murphy and others, 1988), and groundwater (Levings, 1984; Payne and Reiten, 1991; Reiten and Tischmak, 1993; Thamke and Craigg, 1997; Thamke and Midtlyng, 2003; Smith and others, 2006; Peterman and others, 2010; Preston and others, 2013; Rouse and others, 2013).

The main source of historical contamination in the Williston Basin is attributed to inappropriate handling of brine and drilling fluids associated with reserve pits, which are dug at each well location to store produced fluids (Murphy and Kehew, 1984; Beal and others, 1987; Reiten and Tischmak, 1993). Guidelines enacted during the 1970s require that these reserve pits are lined with plastic to reduce the potential of offsite contamination; however, prior to these regulations, pits were unlined and prone to the leaching of brine. More recently (2012), the State of North Dakota established rules prohibiting usage of reserve pits for storage of fluids generated during well completion (North Dakota Century Code, 2013). At present, the most common disposal practice of produced waters in the Williston Basin is through injection into deep geologic formations where the fluids are far removed from surface waters or shallow aquifers. Nevertheless, there are inherent risks of contamination from brine associated with modern recovery operations. Sources of brine releases include breaks in transport pipelines, leaks or unregulated discharges from storage tanks or tanker trucks, and failures of well casings and aging infrastructure (Reiten and Tischmak, 1993; Thamke and Craigg, 1997).

Current exploration and production focuses mainly on the Bakken Formation, which generally contains less formational water than other Williston Basin geologic units. However, flow-back water (hydraulic fracturing fluids that return to the surface when well production is initiated) can present similar storage and disposal challenges, and there is the potential for releases during the tanker-truck transport of the 3,785-18,925 $\mathrm{m}^{3}$ of fracturing fluid to develop each well; thus, while the greatest potential for contamination is from the legacy unlined reserve pits, other potential sources are associated with aging oilfield infrastructure and with current production activities.

\section{Aquatic Resources}

\section{Prairie Pothole Region}

Overlying the northeastern part of the Williston Basin is the PPR (fig. A-1), which spans approximately $770,000 \mathrm{~km}^{2}$ in the north-central United States and south-central Canada. The PPR is characterized by abundant wetland habitats (prairie potholes) that are associated with the production of the majority of North America's waterfowl. In total, about $283,850 \mathrm{~km}^{2}$ of the PPR overlie the Williston Basin or the Bakken Formation; more than a quarter of this area is in the United States. Pothole wetlands, which are described in detail by Kantrud and others (1989) and van der Valk (1989), also are recognized for numerous ecosystem services provided to society including outdoor recreation, wildlife habitat, sequestration of atmospheric carbon, and floodwater storage (Gleason and others, 2008, 2011). Prairie potholes, along with streams and manmade stock ponds, also function as important water sources for livestock and crop irrigation in much of the semiarid Williston Basin.

Historically, the PPR was composed of short-, mixed-, and tall-grass prairie that contained countless isolated wetlands and streams. Currently, land use in the region is dedicated primarily to agricultural production, and a majority of the original wetlands have been lost or altered (Dahl, 1990; Dahl and Johnson, 1991; Gleason and Laubhan, 2008). Because of the land-use effects on these vital habitats such as draining, sedimentation, and additions of agri-chemicals, many public and private conservation organizations are focused on protecting existing wetlands and restoring affected sites. In addition to these obvious land-use effects on wetlands, there are several environmental threats associated with oil and gas production.

The primary risk to surface water and shallow groundwater from oil and gas production in the Williston Basin is the addition of highly saline brine. Effects of brine spills to soils are often evident as barren salt scars, but direct contamination 
of wetlands and streams can go unnoticed. Brine from point sources such as unlined reserve pits can migrate undetected in shallow groundwater over large distances before discharging to surface-water habitats, and brine can accumulate over time in discharge wetlands that are typically low points in the landscape. Because many wetlands lose most of their water through evapotranspiration, the flushing rate of any contaminant that enters the system is low. Additional risks to environmental resources include routine operational activities such as truck and pipeline transport that can lead to accidental spills and road and infrastructure construction that can result in habitat fragmentation and increased sedimentation.

Prairie wetlands and lakes are distinguished by extreme variability in their ionic composition and salinity (TDS and specific conductance) levels (Mitten and others, 1968; Stewart and Kantrud, 1972; Gorham and others, 1983; Swanson and others, 1988; LaBaugh, 1989). Salinity levels often differ considerably among pothole wetlands and lakes and can vary temporally on a seasonal and yearly scale within a single site. Swanson and others (1988) reported that specific conductance from one pothole wetland ranged from 522 to 7,700 microsiemens per centimeter $(\mu \mathrm{S} / \mathrm{cm})$ between wet and dry years, and Hammer (1978) described a Canadian lake where salinity increased by 80 percent within a season. Further, Mitten and others (1968) reported variances in 5-year mean salinity values of approximately 80 percent $(23,100-127,000$ parts per million [ppm]) and 90 percent $(6,500-60,700 \mathrm{ppm})$ from opposing ends of two North Dakota lakes where water exchange is limited.

The primary sources of water for pothole wetlands are spring snowmelt and direct precipitation and runoff during the growing season; evapotranspiration is responsible for the majority of water loss. Climate of the PPR varies along a northwest-to-southeast gradient (Euliss and others, 1999), with precipitation and temperature increasing toward the southeast. While some pothole wetlands contain water throughout most years, a large proportion of these systems dry up seasonally because annual evapotranspiration exceeds precipitation. The topographic position in the landscape also affects salinity and ionic composition as some potholes receive inputs from the groundwater (groundwater discharge sites), whereas others function as groundwater recharge or flow-through sites (Winter, 1989; Winter and Rosenberry, 1995); thus, wetland salinity and ionic composition at any point in time is governed by natural physical processes such as the timing and total amount of precipitation, evaporation, and dilution, as well as interactions with the shallow groundwater system (Winter, 1977).

\section{Chemistry of Surface Water, Shallow Groundwater, and Brine}

Numerous investigations of PPR wetlands have included measures of salinity because of its influence on ecosystem ecology and the composition of the biotic communities. Pothole wetlands are known for their unique vegetation (Stewart and Kantrud, 1971, 1972) and invertebrate (Euliss and others, 1999) communities, which can be sensitive to salinity (Stewart and Kantrud, 1972; Swanson and others, 1988; Euliss and others, 1999; Gleason and others, 2009). Wetlands of this region have concentrations of dissolved solids that encompass the gradient from fresh to saline (LaBaugh, 1989), and in some cases, salinity levels exceed that of seawater. Specific conductance values reported for wetlands and lakes of the Williston Basin and PPR range from 30 to $73,000 \mu \mathrm{S} / \mathrm{cm}$, although most sites were lower than 20,000 $\mu \mathrm{S} / \mathrm{cm}$ (Gorham and others, 1983; Swanson and others, 1988; Euliss and Mushet, 2004; Tangen and others, 2013). Despite the elevated salinities that can occur, often because of late-season evapoconcentration, specific conductance for most prairie pothole wetlands does not exceed 10,000 $\mu \mathrm{S} / \mathrm{cm}$ and is often less than $1,000 \mu \mathrm{S} / \mathrm{cm}$ (LaBaugh and Swanson, 2003; Euliss and Mushet, 2004; Anteau and Afton, 2008; Badiou and others, 2011). Streams throughout the North Dakota part of the Williston Basin have mean TDS concentrations around $1,000 \mathrm{mg} / \mathrm{L}$, with values that rarely exceed 2,000 mg/L (North Dakota Department of Health, unpublished data, 2012; U.S. Geological Survey, unpublished data, 2012). Additionally, Gorham and others (1983) suggest that, in some cases, shallow groundwater in the Dakotas may have TDS levels as high as 3,000 mg/L.

Various investigations have documented that the primary cations present in prairie wetlands are calcium, magnesium, sodium $\left(\mathrm{Na}^{+}\right)$, and potassium; primary anions are bicarbonate $\left(\mathrm{HCO}_{3}^{-}\right)$, sulfate $\left(\mathrm{SO}_{4}^{2-}\right)$, and chloride $\left(\mathrm{Cl}^{-}\right)$(Gorham and others, 1983; Swanson and others, 1988; LaBaugh, 1989; LaBaugh and Swanson, 2003). Swanson and others (1988) identified 7 water types on the basis of the ionic composition of 178 prairie lakes located in south-central North Dakota: calcium bicarbonate, magnesium bicarbonate, sodium bicarbonate, magnesium sulfate, sodium sulfate, sodium chloride $(\mathrm{NaCl})$, and magnesium chloride. Of these lake types, a majority were classified as $\mathrm{SO}_{4}^{2-}\left(62.4\right.$ percent) and $\mathrm{HCO}_{3}^{-}$(33.1 percent) dominated, while only a small proportion were identified as being $\mathrm{Cl}^{-}$(4.5 percent) dominated (Swanson and others, 1988).

Otton (2006) depicts brine from areas of the Williston Basin as having some of the highest TDS concentrations in the United States. However, the chemistry of produced brines is dependent on the location within the Williston Basin and the producing geologic formation(s). For example, Iampen and Rostron (2000) reported that TDS concentrations of Williston Basin brines can range from less than $30,000 \mathrm{mg} / \mathrm{L}$ on the east and southwest flanks to greater than $380,000 \mathrm{mg} / \mathrm{L}$ throughout the deeper parts of the basin. Reiten (1991) reported a mean TDS value of nearly $320,000 \mathrm{mg} / \mathrm{L}$, and Thamke and Craigg (1997) reported TDS concentrations as large as $201,000 \mathrm{mg} / \mathrm{L}$ for Williston Basin brine samples from wells producing predominately from the Mississippian-aged Madison Formation in northeastern Montana. A mean TDS value of approximately $245,000 \mathrm{mg} / \mathrm{L}$ (maximum value of 540,500 mg/L) was calculated using data from over 2,100 oil and gas wells (representing approximately 7,600 samples) producing from numerous 
formations throughout North Dakota (North Dakota Geological Survey, 2002). Moreover, Williston Basin brines often are characterized as being chloride dominated (Reiten, 1991; Reiten and Tischmak, 1993; Thamke and Craigg, 1997; Iampen and Rostron, 2000). As a comparison, pothole wetlands are typically $\mathrm{SO}_{4}^{2-}$ and $\mathrm{HCO}_{3}^{-}$systems with reported salinity values ranging from less than 500 to $70,000 \mu \mathrm{S} / \mathrm{cm}$ (Swanson and others, 1988). Using a model $(\mu \mathrm{S} / \mathrm{cm}=2,289+0.68 \mathrm{TDS})$ presented by Swanson and others (1988), the maximum specific conductance value of $70,000 \mu \mathrm{S} / \mathrm{cm}$ converts to a TDS value of $99,575 \mathrm{mg} / \mathrm{L}$. However, $70,000 \mu \mathrm{S} / \mathrm{cm}$ is unusually high, and specific conductance values ranging from 1,000 to $10,000 \mu \mathrm{S} / \mathrm{cm}$ are considered typical (Swanson and others 1988; LaBaugh and Swanson, 2003; Euliss and Mushet, 2004; Anteau and Afton, 2008; Badiou and others, 2011). This range converts to a TDS of less than $11,340 \mathrm{mg} / \mathrm{L}$ and is significantly less than the values reported for Williston Basin brines.

\section{Brine Contamination}

\section{Ecological Effects of Oil and Gas Production}

There is growing public concern over potential contamination of aquatic resources associated with oil and gas production in the Williston Basin. Numerous studies have demonstrated the effects of brine contamination on the environment (Beal and others, 1987; Reiten, 1991; Reiten and Tischmak, 1993; Thamke and Craigg, 1997), but there is a dearth of information pertaining to the effects of oil and gas production on biological communities, especially those communities associated with aquatic resources. Notable exceptions include a literature review of the effects of energy development on ungulates (for example, deer, elk, pronghorn) in Montana (Hebblewhite, 2008), and a report by Dyke and others (2011) detailing the effects of oil and gas activities on fish and wildlife in North Dakota and the citizens that utilize those resources. Both of these studies relied primarily on existing information (population surveys, habitat requirements, technical reports), and Hebblewhite (2008) concluded that rigorous experiments specifically designed to evaluate the effects of energy development were needed.

Hereafter discussions primarily focus on potential effects of brine contamination to biotic communities associated with wetlands and streams; however, other ecological effects are associated with oil and gas production activities such as pad and road construction, infrastructure development, and increased water usage and vehicle traffic (Hebblewhite, 2008; Dyke and others, 2011). For example, pad or road construction can result in the filling in or increased sedimentation of wetlands, and new road networks can disrupt migration routes and fragment habitat critical to a multitude of taxa including ungulates, grassland-dependent birds, and predators. Increased traffic leads to a greater frequency of vehicle collisions with all manner of wildlife, from small rodents, amphibians, snakes, and birds to large ungulates and predators. Increased disturbance and human presence can also stress wildlife during vulnerable times of the year such as nesting, calving, and winter (Hebblewhite, 2008; Dyke and others, 2011). The enormous amounts of water required for hydraulic fracturing (up to $37,850 \mathrm{~m}^{3}$ per well) also can affect recreational lakes, shallow aquifers (Fischer, 2013), and agricultural irrigation.

There is a lack of scientific information describing the ecological effects of brines on aquatic resources in the Williston Basin. Despite this, assumptions regarding the potential effects of brine on water quality and biotic community structure can be made based on differences in water chemistry between surface and produced waters and the broad suite of literature describing effects of salinity to biotic communities. In general, comparisons of existing data have shown that salt concentrations of Williston Basin brines are significantly greater than the surface water and shallow groundwater of the region (see section, "Chemistry of Surface Water, Shallow Groundwater, and Brine"); thus, the addition of brine to wetlands, streams, and shallow aquifers has the potential to increase salinity. The available water chemistry information further suggests that the ionic composition is quite different between natural and produced waters, with produced waters having much greater $\mathrm{Cl}^{-}$concentrations than most natural surface waters; in fact, Pennak (1989) states that $\mathrm{NaCl}$ concentrations in fresh waters seldom exceed 5 percent of the TDS. On the basis of this information, it is reasonable to assume there is some potential for highly saline brine to raise the salinity levels and to alter the composition of salts in natural aquatic systems. Both of these factors have been shown to affect aquatic biota (Burnham and Peterka, 1975; Swanson and others, 1984; Mount and others, 1997; Zalizniak and others, 2006). Significant inputs of brine could also make water unsuitable for domestic livestock and wildlife, which often rely on natural wetlands and streams or manmade stock ponds for drinking water. The effect of brine contamination to biotic communities, however, would be highly variable depending on factors such as the relative amount of brine introduced to the system, background salt type and concentration, the composition of the biota, and the relation between the wetland and groundwater (recharge, flow through, discharge).

The relation between biotic communities and salinity has been examined in great detail (Poljakoff-Mayber, 1975; Jennings, 1976; Wollheim and Lovvorn, 1995; Parida and Das, 2005; Kefford and others, 2007; Nielsen and others, 2007; Gleason and others, 2009), and most freshwater organisms are restricted to salinity levels that do not exceed $10,000 \mathrm{mg} / \mathrm{L}$ (Pennak, 1989; Wetzel, 2001). Salinity influences plant and invertebrate community composition (Stewart and Kantrud, 1972; Hammer and Heseltine, 1988; Hammer and others, 1990; Gleason and others, 2009) and at certain levels has been shown to reduce survival rates, growth, and development of ducklings (Swanson and others, 1984; Mitcham and Wobeser, 1988; Moorman and others, 1991; DeVink and others, 2005). Williston Basin brines are characterized not only by high salinity levels but by the dominant ions $\mathrm{Na}^{+}$and $\mathrm{Cl}^{-}$. Elevated 
$\mathrm{NaCl}$ concentrations can reduce the germination success of salt-tolerant plants (Baskin and Baskin, 1998), and increased sodicity can affect soil structure, thus impairing plant growth (Bohn and others, 2001; Gleason and others, 2009).

In addition to the overall efforts relating salinity to biotic communities, there have been numerous investigations of the toxicity of produced waters to organisms associated with aquatic ecosystems in other oil and gas producing areas. For example, brines from petroleum production in Texas were found to be toxic to the salt-tolerant sheepshead minnow (Cyprinodon variegatus) when diluted with seawater to a salinity of approximately $52,000 \mathrm{mg} / \mathrm{L}$ (Andreasen and Spears, 1983), and survival and reproduction of a freshwater water flea (Ceriodaphnia dubia) were affected when exposed to water collected downstream from a Wyoming oilfield (Boelter and others, 1992). Rattner and others (1995) also identified nonlethal effects, such as reduced liver weight, to western sandpipers (Calidris mauri) that were attributed to chronic exposure to brine in Texas.

\section{Remediation of Brine Contamination}

There are a variety of approaches that are employed to remediate brine and hydrocarbon spills throughout the country; however, there is little guidance or relevant scientific research pertaining to remediation in the Williston Basin, especially with regards to surface water and groundwater. Most remediation efforts are focused on affected soils where vegetation no longer grows because of increased $\mathrm{Cl}^{-}$concentrations. One conventional practice for remediation of brine-affected soils is excavation and removal; however, this dig-and-haul method is expensive and not practical over a large geographic area. The excess $\mathrm{Na}^{+}$typically associated with brine causes clays to swell, reducing permeability and decreasing the downward movement of water; consequently, one of the primary goals of remediation is to increase soil permeability in order to encourage leaching of $\mathrm{Na}^{+}$from the root zone, thereby promoting revegetation. Perhaps the most common method for increasing permeability is to treat affected soils with a calcium-based salt, such as gypsum, with the goal of replacing the $\mathrm{Na}^{+}$in the clay matrix (De Jong, 1982; Liang and others, 1995; Merrill and others, 1990; Bohn and others, 2001). This cation exchange increases infiltration and enhances the leaching of $\mathrm{Na}^{+}$from the upper soil profile. Although this type of treatment is effective for enhancing plant growth at affected sites, ions leached from the upper soil profile could still be transported to wetlands through shallow groundwater flow.

In addition to chemical treatments, alternative soil-remediation methods include tillage, irrigation, incorporation of various soil amendments (organic soil, manure, hay, sand, fertilizer), phytoremediation, and installation of subsurface drainage tile or downslope trenches to enhance lateral transport and intercept contaminated water (Korphage and others, 2003; Harris and others, 2005; Sublette and others, 2005). Tillage and the addition of soil amendments increase soil permeability through direct disturbance and the mixing of porous materials with tight clays. Similarly, establishment of salt-tolerant plants enhances permeability through the root zone, and these plants can also fix salts in their leaves and stems. Recently developed methodologies include the use of hydraulic fracturing of soils to enhance water recovery for desalinization and disposal (Robertson and others, 2006).

In addition to affecting soils, brine often contaminates the shallow groundwater system. The most common technique employed to remediate brine-affected groundwater is the pump-and-treat method, which consists of pumping contaminated water to the surface where it is treated and reinjected (Keely, 1989). The relative success and time involved to achieve site remediation using these various approaches differs according to factors such as soil properties (porosity and permeability), amount and concentration of brine introduced, precipitation, and groundwater flow paths and velocities.

In a review of publications pertaining to brine remediation, Vavrek and others (2004) identified information relating to brine spills, site characteristics, and restoration success as primary information gaps and suggested that phytoremediation is a feasible alternative to the dig-and-haul method, and assessments of recovered plant communities may be the best way to evaluate remediation and restoration of affected soils in the long term. Within the Williston Basin, especially in the PPR, contamination of wetlands is a primary concern. Hence, in addition to addressing data gaps related to remediation of contaminated soils and groundwater, baseline research is required to identify and evaluate remediation approaches for surface waters.

\section{Summary}

The Williston Basin has a long-standing history of oil and gas production and is in the midst of a modern oil boom made possible by advancements in drilling technologies, which allow for the recovery of oil from deep, low-permeability geologic formations. Along with the many economic benefits associated with oil and gas production, there are potential environmental effects linked to legacy reserve pits, modern recovery operations, fluid transport by tanker trucks and pipelines, and infrastructure construction. The Prairie Pothole Region has been widely recognized for its freshwater habitats, which have potential to be chemically and biologically altered by contamination from brine produced in the Williston Basin. Although brine contamination has been identified in areas of the Williston Basin, little research has been performed to assess potential ecological effects or to evaluate remediation techniques. Therefore, monitoring and research are required to identify contamination and any associated ecologic effects, as well as to determine the most appropriate ways to remediate contaminated sites. 


\section{References}

Andreasen, J.K., and Spears, R.W., 1983, Toxicity of Texan petroleum well brine to the sheepshead minnow (Cyprinodon variegatus), a common estuarine fish: Bulletin of Environmental Contamination and Toxicology, v. 30, p. $277-283$.

Anna, L.O., Pollastro, R.M., Gaswirth, S.B, Lewan, M.D., Lillis, P.G., Roberts, L.N.R., Schenk, C.J., Charpentier, R.R., Cook, T.A., and Klett, T.R., 2008, Assessment of undiscovered oil and gas resources of the Williston Basin Province of North Dakota, Montana, and South Dakota, 2008: U.S. Geological Survey Fact Sheet 2008-3092, 2 p.

Anna, L.O., Pollastro, Richard, and Gaswirth, S.B., 2011, Williston Basin Province-Stratigraphic and structural framework to a geologic assessment of undiscovered oil and gas resources, chap. 2 in U.S. Geological Survey Williston Basin Province Assessment Team, Assessment of undiscovered oil and gas resources of the Williston Basin Province of North Dakota, Montana, and South Dakota, 2010: U.S. Geological Survey Digital Data Series 69-W, 17 p.

Anteau, M.J., and Afton, A.D., 2008, Amphipod densities and indices of wetland quality across the upper-Midwest, USA: Wetlands, v. 28, p. 184-196.

Badiou, P., McDougal, R., Pennock, D., and Clark, B., 2011, Greenhouse gas emissions and carbon sequestration potential in restored wetlands of the Canadian prairie pothole region: Wetlands Ecology and Management, v. 19, p. 237-256.

Baker, F.G., and Brendecke, C.M., 1983, Seepage from oilfield brine disposal ponds in Utah: Ground Water, v. 21, p. $317-324$

Baskin, C.C., and Baskin, J.M., 1998, Seeds-Ecology, biogeography, and evolution of dormancy and germination: San Diego, Calif., Academic Press, 666 p.

Beal, W.A., Murphy, E.C., and Kehew, A.E., 1987, Migration of contaminants from buried oil-and-gas drilling fluids within the glacial sediments of north-central North Dakota: North Dakota Geological Survey, Report of Investigation No. 86,43 p.

Bluemle, J.P., 2000, The face of North Dakota-The geologic story ( $3 \mathrm{~d}$ ed.): Bismarck, North Dakota Geological Survey Educational Series 26.

Boelter, A.M., Lamming, F.N., Farag, A.M., and Bergman, H.L., 1992, Environmental effects of saline oil-field discharges on surface waters: Environmental Toxicology and Chemistry, v. 11, p. 1187-1195.
Bohn, H.L., McNeal, B.L., and O’Connor, G.A., 2001, Saltaffected soils, in Bohn, H.L., McNeal, B.L., and O'Connor, G.A., eds., Soil Chemistry (3d ed.): New York, N.Y., John Wiley and Sons, p. 281-301.

Burnham, B.L., and Peterka, J.J., 1975, Effects of saline water from North Dakota lakes on survival of fathead minnow (Pimephales promelas) embryos and sac fry: Journal of the Fisheries Resources Board of Canada, v. 32, p. 809-812.

Dahl, T.E., 1990, Wetland losses in the United States, 1780s to 1980s: Washington, D.C., U.S. Department of the Interior, Fish and Wildlife Service.

Dahl, T.E., and Johnson, C.E., 1991, Status and trends of wetlands in the coterminous United States, mid-1970s to mid1980s: Washington, D.C., U.S. Department of the Interior, Fish and Wildlife Service.

De Jong, E., 1982, Reclamation of soils contaminated by sodium chloride: Canadian Journal of Soil Science, v. 62, p. 351-364.

DeVink, J-M.A., Gilchrist, H.G., and Diamond, A.W., 2005, Effects of water salinity on growth and survival of common eider (Somateria mollissima) duckings: The Auk, v. 122, p. 523-529.

DiGiulio, D.C., Wilkin, R.T., Miller, C., and Oberley, G., 2011, Draft investigation of ground water contamination near Pavillion, Wyoming: U.S. Environmental Protection Agency Draft Report, EPA 600/R/00-0000, 121 p., accessed July 1, 2013, at http://www2.epa.gov/region8/draftinvestigation-ground-water-contamination-near-pavillionwyoming.

Durham, L.S., 2010, Bakken fractures yield the goods, oil shale takes turn in spotlight: American Association of Petroleum Geologists Explorer, v. 31, p. 34-36, accessed November 1, 2013, at http://www.aapg.org/explorer/2010/10oct/ index.cfm.

Dyke, S., Fryda, D., Kleyer, D., Williams, J., Hosek, B., Jensen, W., Johnson, S., Robinson, A., Ryckman, F., Stillings, B., Szymanski, M., Tucker, S., and Wiedmann, B., 2011, Potential impacts of oil and gas development on select North Dakota natural resources; a report to the director: North Dakota Game and Fish Department, 120 p.

Euliss, N.H., Jr., and Mushet, D.M., 2004, Impacts of water development on aquatic macroinvertebrates, amphibians, and plants in wetlands of a semi-arid landscape: Aquatic Ecosystem Health \& Management, v. 7, p. 73-84. 
Euliss, N.H., Jr., Wrubleski, D.A., and Mushet, D.M., 1999, Wetlands of the Prairie Pothole Region: Invertebrate species composition, ecology, and management, in Batzer, D.P., Rader, R.B., and Wissinger, S.A., eds., Invertebrates in Freshwater Wetlands of North America: Ecology and Management: New York, N.Y., John Wiley and Sons, p. 471-514.

Eyles, N., and Menzies, J., 1983, The subglacial landsystem, in Eyles, N., ed., Glacial Geology: Toronto, Pergamon Press, p. 19-71.

Fischer, K., 2013, Groundwater flow model inversion to assess water availability in the Fox Hills-Hell Creek aquifer: North Dakota State Water Commission Water Resources Investigation No. 54, $325 \mathrm{p}$.

Fullerton, D.S., Colton, R.B., Bush, C.A., and Straub, A.W., 2004, Map showing spatial and temporal relations of mountain and continental glaciations in the Northern Plains, primarily in northern Montana and northwestern North Dakota: Pamphlet to accompany U.S. Geological Survey Scientific Investigations Map 2843.

Gaswirth, S.B., Marra, K.R., Cook, T.A, Charpentier, R.R., Gautier, D.L., Higley, D.K., Klett, T.R., Lewan, M.D., Lillis, P.G., Schenk, C.J., Tennyson, M.E., and Whidden, K.J., 2013, Assessment of undiscovered oil resources in the Bakken and Three Forks Formations, Williston Basin Province, Montana, North Dakota, and South Dakota, 2013: U.S. Geological Survey Fact Sheet 2013-3013, 4 p., http://pubs. usgs.gov/fs/2013/3013/.

Gerhard, L.C., Anderson, S.B., and Fischer, D.W., 1991, Petroleum geology of the Williston Basin, in Leighton, M., Kolata, D., Oltz, D., and Eidel, J., eds., Petroleum geology of interior cratonic basins: American Association of Petroleum Geologists, Memoir 51, p. 507-559.

Gleason, R.A., Euliss, N.H., Jr., Tangen, B.A., Laubhan, M.K., and Browne, B.A., 2011, USDA conservation program and practice effects on wetland ecosystem services in the Prairie Pothole Region: Ecological Applications, v. 21, Supplement, p. S65-S81.

Gleason, R.A., and Laubhan, M.K., 2008, Background and approach to quantification of ecosystem services, in Gleason, R.A., Laubhan, M.K., and Euliss, N.H., Jr., eds., Ecosystem services derived from wetland conservation practices in the United States Prairie Pothole Region with an emphasis on the U.S. Department of Agriculture Conservation Reserve and Wetlands Reserve Programs: U.S. Geological Survey Professional Paper 1745, p. 3-14.
Gleason, R.A., Laubhan, M.K., and Euliss, N.H., Jr., eds., 2008, Ecosystem services derived from wetland conservation practices in the United States Prairie Pothole Region with an emphasis on the U.S. Department of Agriculture Conservation Reserve and Wetlands Reserve Programs: U.S. Geological Survey Professional Paper 1745, 58 p.

Gleason, R.A., Tangen, B.A., Laubhan, M.K., Finocchiaro, R.G., and Stamm, J.F., 2009, Literature review and database of relations between salinity and aquatic biota-Applications to Bowdoin National Wildlife Refuge, Montana: U.S. Geological Survey Scientific Investigations Report 20095098, 76 p.

Gorham, E., Dean, W.E., and Sanger, J.E., 1983, The chemical composition of lakes in the north-central United States: Limnology and Oceanography, v. 28, p. 287-301.

Gorman, H.S., 1999, Efficiency, environmental quality, and oil field brines - The success and failure of pollution control by self-regulation: Business History Review, v. 73, p. 601-640.

Grisak, G.E., and Cherry, J.A., 1975, Hydrologic characteristics and response of fractured till and clay confining a shallow aquifer: Canadian Geotechnical Journal, v. 12, p. 513-515.

Hammer, U.T., 1978, The saline lakes of Saskatchewan III., chemical characterization: Internationale Revue der gesamten Hydrobiologie und Hydrographie, v. 63, p. 311- 335.

Hammer, U.T., and Heseltine, J.M., 1988, Aquatic macrophytes in saline lakes of the Canadian prairies: Hydrobiologia, v. 158, p. 101-116.

Hammer, U.T., Sheard, J.S., and Kranabetter, J., 1990, Distribution and abundance of littoral benthic fauna in Canadian prairie saline lakes: Hydrobiologia, v. 197, p. 173-192.

Harris, T.M., Tapp, J.B., and Sublette, K.L., 2005, Remediation of oil-field brine-impacted soil using a subsurface drainage system and hay: Environmental Geosciences, v. 12, p. 101-113.

Hebblewhite, M., 2008, A literature review of the effects of energy development on ungulates - Implications for central and eastern Montana: Miles City, Montana, Report prepared for Montana Fish, Wildlife and Parks, 125 p.

Hendry, M.J., 1988, Hydrogeology of clay till in a Prairie region of Canada: Ground Water, v. 26, p. 607-614.

Iampen, H.T., and Rostron, B.J., 2000, Hydrogeochemistry of pre-Mississippian brines, Williston Basin, Canada-USA: Journal of Geochemical Exploration, v. 69-70, p. 29-35.

IHS Energy, 2011, U.S. well production file on CD-ROM, IHS Energy, Houston, Texas. 
Jennings, D.H., 1976, The effects of sodium chloride on higher plants: Biological Reviews, v. 51, p. 453-486.

Kalkhoff, S.J., 1993, Brine contamination of ground water and streams in the Baxterville oil field area, Lamar and Marion Counties, Mississippi: U.S. Geological Survey WaterResources Investigations Report 93-4147, 37 p.

Kantrud, H.A., Krapu, G.L., and Swanson, G.A., 1989, Prairie basin wetlands of the Dakotas - A community profile:

U.S. Fish and Wildlife Service Biological Report 85 (7.28), $116 \mathrm{p}$.

Keely, J.F., 1989, Performance evaluations of pump-andtreat remediations: U.S. Environmental Protection Agency, EPA/540/4-89/005, 19 p.

Kefford, B.J., Nugegoda, D., Zalizniak, L., Fields, E.J., and Hassell, K.L., 2007, The salinity tolerance of freshwater macroinvertebrate eggs and hatchlings in comparison to their older life-stages - A diversity of responses: Aquatic Ecology, v. 41, p. 335-348.

Korphage, M.L., Langhus, B.G., and Campbell, S., 2003, Applied phyto-remediation techniques using halophytes for oil and brine spill scars: Final report prepared by ALL Consulting for the Kansas Corporation Commission, online report, accessed June 1, 2011, at http://www.netl.doe.gov/ technologies/oil-gas/publications/EP/15328FinalRpt.pdf.

LaBaugh, J.W., 1989, Chemical characteristics of water in northern prairie wetlands, in van der Valk, A., ed., Northern Prairie Wetlands: Ames, Iowa State University Press, p. 56-90.

LaBaugh, J.W., and Swanson, G.A., 2003, Spatial and temporal variability in specific conductance and chemical characteristics of wetland water and in water column biota in the wetlands in the Cottonwood Lake area, in Winter, T.C., ed., Hydrological, chemical, and biological characteristics of a prairie pothole wetland complex under highly variable climate conditions - the Cottonwood Lake area, east-central North Dakota: U.S. Geological Survey Professional Paper 1675 , p. 35-53.

Lang, K.J., and Doll, E.C., 1983, Salt distribution around a buried brine disposal pit: North Dakota State University, Land Reclamation Research Center, Technical Report No. 1, $10 \mathrm{p}$.

Levings, G.W., 1984, Reconnaissance evaluation of contamination in the alluvial aquifer in the East Poplar oil field, Roosevelt County, Montana: U.S. Geological Survey Water Resources Investigations Report 84-4174, 33 p.
Liang, J., Karamanos, R.E., and Moir, M.E., 1995, The influence of brine contamination and phosphogypsum amendments on soil chemical properties and plant response: Communications in Soil Science and Plant Analysis: v. 26, p. 1033-1057.

McMillion, L.G., 1965, Hydrologic aspects of disposal of oilfield brines in Texas: Ground Water, v. 3, p. 36-42.

Merrill, S.D., Lang, K.J., and Doll, E.C., 1990, Contamination of soil with oilfield brine and reclamation with calcium chloride: Soil Science, v. 150, p. 469-475.

Miall, A.D., 1983, Glaciofluvial transport and deposition, in Eyles, N., ed., Glacial Geology, Toronto, Pergamon Press, p. 168- 183.

Mitcham, S.A., and Wobeser, G., 1988, Effects of sodium and magnesium sulfate in drinking water on mallard ducklings: Journal of Wildlife Diseases, v. 24, p. 30-44.

Mitten, H.T., Scott, C.H., and Rosene, P.G., 1968, Chemical quality of surface waters in Devils Lake Basin North Dakota, 1952-60: U.S. Geological Survey Water-Supply Paper 1859-B, $42 \mathrm{p}$.

Moorman, A.M., Moorman, T.E., Baldassarre, G.A., and Richard, D.M., 1991, Effects of saline water on growth and survival of mottled duck ducklings in Louisiana: Journal of Wildlife Management, v. 55, p. 471-476.

Mount, D.R., Gulley, D.D., Hockett, J.R., Garrison, T.D., and Evans, J.M., 1997, Statistical models to predict the toxicity of major ions to Ceriodaphnia dubia, Daphnia magna, and Pimephales promelas (fathead minnows): Environmental Toxicology and Chemistry, v. 16, p. 2009-2019.

Murphy, E.C., and Kehew, A.E., 1984, The effect of oil and gas well drilling fluids on shallow groundwater in western North Dakota: North Dakota Geological Survey, Report of Investigation No. 82, 156 p.

Murphy, E.C., Kehew, A.E., Groenewold, G.H., and Beal, W.A., 1988, Leachate generated by an oil-and-gas brine pond site in North Dakota: Ground Water, v. 26, p. 31-38.

Nelson, K.J., 2006, Impacts of oil exploration and production to the northeast Montana Wetland Management District: U.S. Fish and Wildlife Service, Region 6 Environmental Contaminants Program Investigations Report, Project 6N51.

Nielsen, D.L., Brock, M.A., Petrie, R., and Crossle, K., 2007, The impact of salinity pulses on the emergence of plant and zooplankton from wetland seed and egg banks: Freshwater Biology, v. 52, p. 784-795.

North Dakota Century Code, 2013, Title 38-Mining and gas and oil production, accessed July 1, 2013, at $h t t p: / / w w w$. legis.nd.gov/cencode/t38.html. 
North Dakota Geological Survey, 2002, Catalog of water chemistries (as of March 7, 2002), accessed June 1, 2011, at https://www.dmr.nd.gov/ndgs/Extractable_Files/watercat. asp.

Otton, J.K., 2006, Environmental aspects of produced-water salt releases in onshore and coastal petroleum-producing areas of the conterminous U.S.-A bibliography: U.S. Geological Survey Open-File Report 2006-1154, 223 p.

Papoulias, D.M., and Velasco, A.L., 2013, Histopathological analysis of fish from Acorn Fork Creek, Kentucky, exposed to hydraulic fracturing fluid releases: Southeastern Naturalist, v. 12, p. 92-111.

Parida, A.K., and Das, A.B., 2005, Salt tolerance and salinity effects on plants- A review: Ecotoxicology and Environmental Safety, v. 60, p. 324-349.

Payne, S.M., and Reiten, J.C., 1991, Impacts of oil field wastes on soil and ground water in Richland County, Montana, Part III-Hydrogeologic conditions and ground water quality at an oil well reserve pit, Richland County, Montana: Montana Bureau of Mines and Geology Open-File Report 237- C, 120 p.

Pennak, R.W., 1989, Fresh-water invertebrates of the United States-Protozoa to mollusca (3d ed.): New York, N.Y., John Wiley and Sons, 628 p.

Peterman, Z.E., Thamke, J.N., Futa, K., and Oliver, T.A., 2010, Strontium isotope detection of brine contamination in the East Poplar oil field, Montana: U.S. Geological Survey Open-File Report 2010-1326, 20 p.

Peterson, J.A., 1995, Williston Basin Province (031): U.S. Geological Survey, 1995 National Assessment of United States Oil and Gas Resources, accessed June 1, 2011, at http://certmapper.cr.usgs.gov/data/noga95/prov31/text/ prov31.pdf.

Poljakoff-Mayber, A., 1975, Morphological and anatomical changes in plants as a response to salinity stress, in Poljakoff-Mayber, A., and Gale, J., eds., Plants in saline environments: New York, Heidelberg, Berlin, Springer-Verlag, $p$. 97-117.

Pollastro, R.M., Roberts, L.N.R., Cook, T.A., and Lewan, M.D., 2008a, Assessment of undiscovered technically recoverable oil and gas resources of the Bakken Formation, Williston Basin, Montana and North Dakota, 2008: U.S. Geological Survey Open-File Report 2008-1353, 3 sheets.
Pollastro, R.M., Cook, T.A., Roberts, L.N.R., Schenk, C.J., Lewan, M.D., Anna, L.O., Gaswirth, S.B., Lillis, P.G., Klett, T.R., and Charpentier, R.R., 2008b, Assessment of undiscovered oil resources in the Devonian-Mississippian Bakken Formation, Williston Basin Province, Montana and North Dakota, 2008: U.S. Geological Survey Fact Sheet 2008-3021, 2 p.

Preston, T.M., Chesley-Preston, T.L., and Thamke, J.N., 2013, A GIS-based vulnerability assessment of brine contamination to aquatic resources from oil and gas development in eastern Sheridan County, Montana: Science of the Total Environment, http://dx.doi.org/10.1016/j. scitotenv.2013.09.027.

Rattner, B.A., Capizzi, J.L., King, K.A., LeCaptain, L.J., and Melancon, M.J., 1995, Exposure and effects of oilfield brine discharges on western sandpipers (Calidris mauri) in Nueces Bay, Texas: Bulletin of Environmental Contamination and Toxicology, v. 54, p. 683-689.

Reiten, J.C., 1991, Impacts of oil field wastes on soil and ground water in Richland County, Montana, Part I-Overview: Montana Bureau of Mines and Geology Open-File Report 237-A, $25 \mathrm{p}$.

Reiten, J.C., and Tischmak, T., 1993, Appraisal of oil field brine contamination in shallow ground water and surface water, eastern Sheridan County, Montana: Billings, Mont., Montana Bureau of Mines and Geology Open-File Report 260, 296 p., 2 sheets.

Robertson, C., Ratiu, I., and Bures, G.H., 2006, In-situ remediation of brine impacted soils and groundwater using hydraulic fracturing, desalinization, and recharge wells: Proceedings of the 2006 Remediation Technologies Symposium, accessed June 1, 2011, at http://www.esaa-events.com/ remtech/2006/default.htm.

Rouse, D.R., Nelson, K.J., and Reiten, J.C., 2013, Impacts of oil exploration and production to the Northeast Montana Wetland Management District: Montana Bureau of Mines and Geology Open-File Report 620, 264 p., 1 sheet. (Also available at http://www.mbmg.mtech.edu/mbmgcat/public/ ListCitation.asp?pub_id=31635\&.)

Sandberg, C.A., 1962, Geology of the Williston Basin, North Dakota, Montana, and South Dakota, with reference to subsurface disposal of radioactive wastes: U.S. Geological Survey Open-File Report 62-115, 148 p.

Schuh, W.M., 2010, Water appropriation requirements, current water use, \& water availability for energy industries in North Dakota, a 2010 summary: North Dakota State Water Commission, Water Resources Investigation No. 49. 
Smith, B.D., Thamke, J.N., Cain, M.J., Tyrrell, C., and Hill, P.L., 2006, Helicopter electromagnetic and magnetic survey maps and data, East Poplar oil field area, Fort Peck Indian Reservation, northeastern Montana, August 2004: U.S. Geological Survey Open-File Report 2006-1216, 23 p.

Stewart, R.E., and Kantrud, H.A., 1971, Classification of natural ponds and lakes in the glaciated prairie region: U.S. Fish and Wildlife Service Resource Publication 92, 57 p.

Stewart, R.E., and Kantrud, H.A., 1972, Vegetation of prairie potholes, North Dakota, in relation to quality of water and other environmental factors: U.S. Geological Survey Professional Paper 585- D, $36 \mathrm{p}$.

Sublette, K.L., Moralwar, A., Ford, L., Duncan, K., Thoma, G., and Brokaw, J., 2005, Remediation of a spill of crude oil and brine without gypsum: Environmental Geosciences, v. 12, p. 115-125.

Swanson, G.A., Adomaitis, V.A., Lee, F.B., Serie, J.R., and Shoesmith, J.A., 1984, Limnological conditions influencing duckling use of saline lakes in south-central North Dakota: Journal of Wildlife Management, v. 48, p. 340-349.

Swanson, G.A., Winter, T.C., Adomaitis, V.A., and LaBaugh, J.W., 1988, Chemical characteristics of prairie lakes in south-central North Dakota-Their potential for influencing use by fish and wildlife: U.S. Fish and Wildlife Service Fish and Wildlife Technical Report 18, 44 p.

Tangen, B.A., Gleason, R.A., and Stamm, J.F., 2013, A model for evaluating effects of climate, water availability, and water management on wetland impoundments - A case study on Bowdoin, Long Lake, and Sand Lake National Wildlife Refuges: U.S. Geological Survey Scientific Investigations Report 2013-5114, 37 p., http://pubs.usgs.gov/ sir/2013/5114/.

Thamke, J.N., and Craigg, S.D., 1997, Saline-water contamination in Quaternary deposits and the Poplar River, East Poplar oil field, northeastern Montana: U.S. Geological Survey Water-Resources Investigations Report 97-4000, 37 p.

Thamke, J.N., and Midtlyng, K.S., 2003, Ground-water quality for two areas in the Fort Peck Indian Reservation, northeastern Montana, 1993-2000: U.S. Geological Survey WaterResources Investigations Report 03-4214, 54 p. van der Valk, A., ed., 1989, Northern Prairie Wetlands: Ames, Iowa State University Press.

Vavrek, M.C., Hunt, H. Colgan, W., and Vavrek, D.L., 2004, Status of oil brine spill site remediation: Proceedings of the 11th Annual International Petroleum Environmental Conference, accessed June 1, 2011, at http://ipec.utulsa.edu/ Conf2004/Papers/vavrek_hunt_colgan_vavrek.pdf.

Veil, J.A., Puder, M.G., Elcock, D., Redweik, R.J., Jr., 2004, A white paper describing produced water from production of crude oil, natural gas, and coal bed methane: Prepared for the U.S. Department of Energy, National Energy Technology Laboratory by Argonne National Laboratory, Argonne, Ill., $79 \mathrm{p}$.

Wanty, R.B., 1997, USGS research on saline waters co-produced with energy resources: U.S. Geological Survey Fact Sheet 003-97, 3 p.

Wetzel, R.G., 2001, Limnology, lake and river ecosystems (3d ed.): San Diego, Calif., Academic Press, 1006 p.

Winter, T.C., 1977, Classification of the hydrologic settings of lakes in the north central United States: Water Resources Research, v. 13, p. 753-767.

Winter, T.C., 1989, Hydrologic studies of wetlands in the northern prairie, in van der Valk, A., ed., Northern Prairie Wetlands: Ames, Iowa State University Press, p. 16-54.

Winter, T.C., and Rosenberry, D.O., 1995, The interaction of ground water with prairie pothole wetlands in the Cottonwood Lake area, east-central North Dakota, 1979-1990: Wetlands, v. 15, p. 193-211.

Wollheim, W.M., and Lovvorn, J.R., 1995, Salinity effects on macroinvertebrate assemblages and waterbird food webs in shallow lakes of the Wyoming high plains: Hydrobiologia, v. 310 , p. $207-223$.

Zalizniak, L., Kefford, B.J., and Nugegoda, D., 2006, Is all salinity the same? I. The effect of ionic compositions on the salinity tolerance of five species of freshwater invertebrates: Marine and Freshwater Research, v. 57, p. 75-82. 


\section{Brine Contamination of Prairie Pothole Environments at Three Study Sites in the Williston Basin, United States}

By Todd M. Preston, Joanna N. Thamke, Bruce D. Smith, and Zell E. Peterman

Chapter B of

Brine Contamination to Aquatic Resources from Oil and Gas Development in the Williston Basin, United States

Edited by Robert A. Gleason and Brian A. Tangen

Scientific Investigations Report 2014-5017 
Suggested citation:

Gleason, R.A., and Tangen, B.A., eds., 2014, Brine contamination to aquatic resources from oil and gas development in the Williston Basin, United States: U.S. Geological Survey Scientific Investigations Report 2014-5017, 127 p.,

http://dx.doi.org/10.3133/sir20145017.

Suggested citation for this chapter:

Preston, T.M., Thamke, J.N., Smith, B.D., Peterman, Z.E., 2014, Brine contamination of prairie pothole environments at three study sites in the Williston Basin, United States, chap. B of Gleason, R.A., and Tangen, B.A., eds., Brine contamination to aquatic resources from oil and gas development in the Williston Basin, United States: U.S. Geological Survey Scientific Investigations Report 2014-5017, p. 21-62. 


\section{Contents}

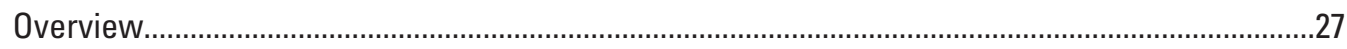

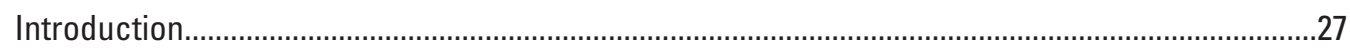

Brine Chemistry in the Williston Basin ...............................................................................2

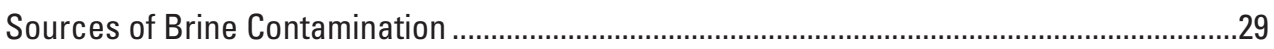

Identification of Brine Contamination ..................................................................................30

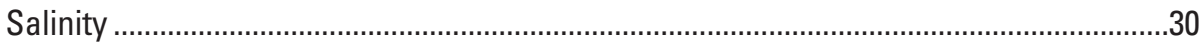

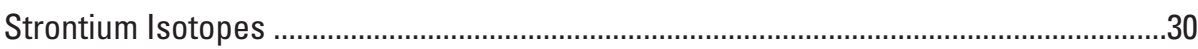

Electromagnetic Properties …………………………...............................................

Study Sites and Previous Research ....................................................................................

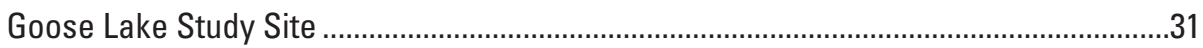

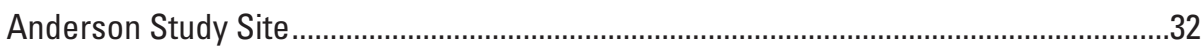

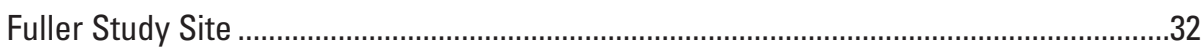

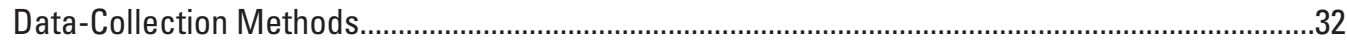

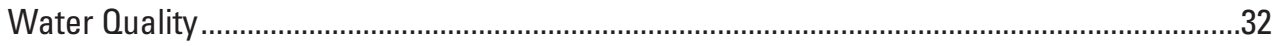

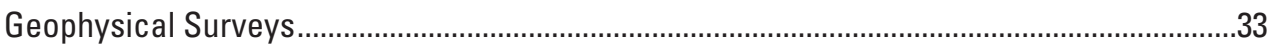

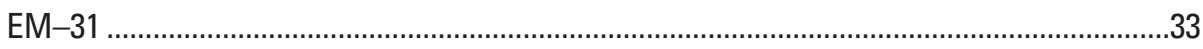

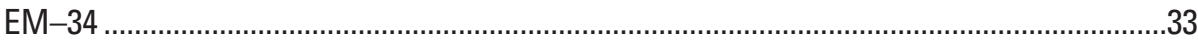

GEM-2

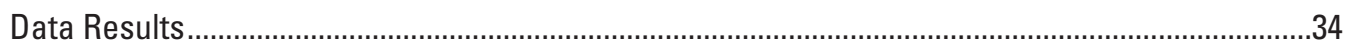

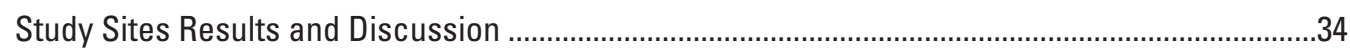

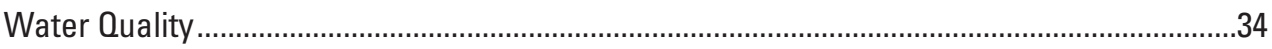

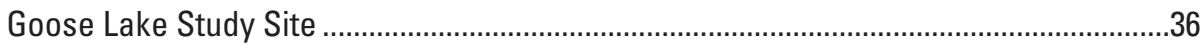

Anderson Study Site............................................................................................... 41

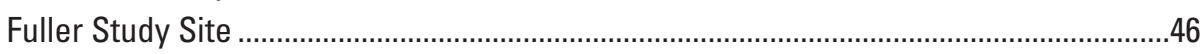

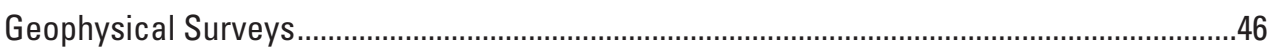

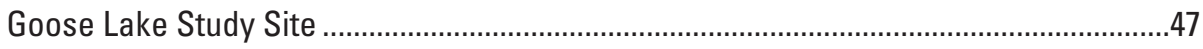

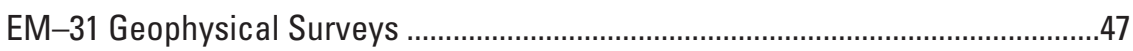

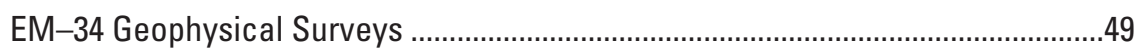

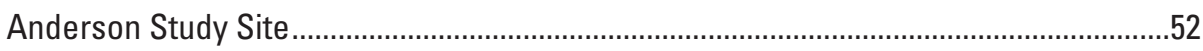

EM-31 Geophysical Surveys ........................................................................

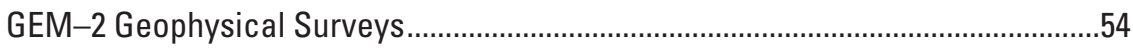

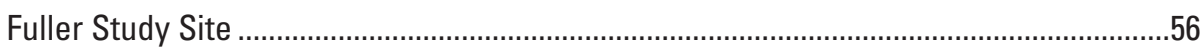

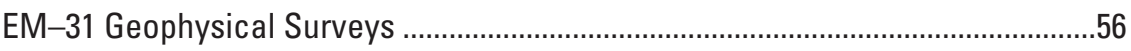

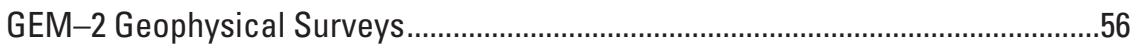

Summary —Brine Contamination of Prairie Pothole Environments in the Williston Basin .............59

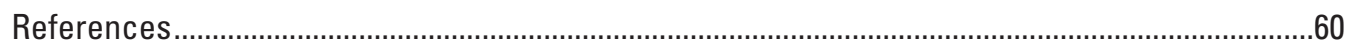




\section{Figures}

B-1. Map showing location of the three study sites and the extent of the Williston Basin, Bakken Formation, and the Prairie Pothole Region....

B-2. Graph showing sodium/chloride molar ratio compared to contamination index for 96 water-quality samples and 5 brine samples.

B-3. Maps showing Goose Lake study site showing the location of water samples, oil wells, tank battery, National Wetlands Inventory wetlands, and the Rabenberg Waterfowl Production Area, and the 1989 contamination index values, 2009 contamination index values, and the change in contamination index values.

B-4. Graph showing strontium concentration compared to $87 \mathrm{Sr} / 86 \mathrm{Sr}$ values for water samples from all three study sites: Goose Lake, Anderson, and Fuller .41

B-5. Graph showing contamination index values of surface water and groundwater samples from 1989, 2006, and 2009 plotted by distance from the most upgradient brine source in the northern groundwater-flow path at the Goose Lake study site .......42

B-6. Graph showing contamination index values of surface water and groundwater samples from 1989, 2005, and 2009 plotted by distance from the most upgradient brine source in the southern groundwater-flow path at the Goose Lake study site.......43

B-7. Maps showing Anderson study site showing the location of water samples, oil wells, tank batteries, National Wetlands Inventory wetlands, and the Anderson Waterfowl Production Area, and the 2004-5 contamination index values, 2010 contamination index values, and the change in contamination index values.

B-8. Graph showing contamination index values of surface water and groundwater samples from 2004-5 and 2010 plotted by distance from the most upgradient brine source in the groundwater-flow path at the Anderson study site

B-9. Map showing uller study site showing the locations of water samples, oil well 01057, tank battery, National Wetlands Inventory wetlands, the Fuller Waterfowl Production Area boundary, and the contamination index values from 2010.

B-10. Map showing Goose Lake study site showing the location of water samples, oil wells, tank battery, National Wetlands Inventory wetlands, and the Rabenberg Waterfowl Production Area, as well as the 2005-6 contamination index values and apparent conductivity results from the 2004 EM-31 geophysical surveys..

B-11. Map showing Goose Lake study site showing the location of water samples, oil wells, tank battery, National Wetlands Inventory wetlands, and the Rabenberg Waterfowl Production Area, as well as the 2009 contamination index values and apparent conductivity results from the 2009 EM-31 geophysical surveys.....

B-12. Maps showing Goose Lake study site showing the location of water samples, oil wells, tank battery, National Wetlands Inventory wetlands, and the Rabenberg Waterfowl Production Area, as well as 2009 contamination index values and apparent conductivity results from the 2009 EM-34 10-meter (m) horizontal dipole, 20-m horizontal dipole, and 40-m horizontal dipole geophysical surveys.

B-13. Maps showing Goose Lake study site showing the location of water samples, oil wells, tank battery, National Wetlands Inventory wetlands, and the Rabenberg Waterfowl Production Area, as well as 2009 contamination index values and apparent conductivity results from the 2009 EM-34 10-meter $(\mathrm{m})$ vertical dipole, 20-m vertical dipole, and 40-m vertical dipole geophysical surveys

B-14. Map showing Anderson study site showing the location of water samples, oil wells, tank battery, National Wetlands Inventory wetlands, and the Anderson Waterfowl Production Area, as well as the 2004-5 contamination index values and apparent conductivity results from the 2004 EM-31 geophysical surveys. 
B-15. Map showing Anderson study site showing the location of water samples, oil wells, tank batteries, National Wetlands Inventory wetlands, and the Anderson Waterfowl Production Area, as well as the 2010 contamination index values and apparent conductivity results from the $2010 \mathrm{EM}-31$ geophysical surveys.

B-16. Maps showing Anderson study site showing the location of water samples, oil wells, tank batteries, National Wetlands Inventory wetlands, and the Anderson Waterfowl Production Area, as well as 2010 contamination index values and apparent conductivity results from the 2010 GEM-2 geophysical surveys for the 93,030 hertz $(\mathrm{Hz}), 47,970 \mathrm{~Hz}$, and $1,530 \mathrm{~Hz}$ frequencies ..

B-17. Map showing Fuller study site showing the location of water samples, oil well 01057, tank battery, National Wetlands Inventory wetlands, and the Fuller Waterfowl Production Area boundary, as well as the 2010 contamination index values and apparent conductivity results from the 2010 EM-31 geophysical survey ....57

B-18. Maps showing Fuller study site showing the location of water samples, oil well 01057, tank battery, National Wetlands Inventory wetlands, and the Fuller Waterfowl Production Area boundary, as well as 2010 contamination index values and apparent conductivity results from the 2010 GEM-2 geophysical surveys for the 93,030 hertz $(\mathrm{Hz}), 47,970 \mathrm{~Hz}$, and $1,530 \mathrm{~Hz}$ frequencies

\section{Tables}

B-1. Summary of water-quality data for the Goose Lake study site, Sheridan County, Montana

B-2. Summary of water-quality data for the Anderson study site, Sheridan County, Montana

B-3. Summary of water-quality data for the Fuller study site, Williams County, North Dakota. 



\title{
Brine Contamination of Prairie Pothole Environments at Three Study Sites in the Williston Basin, United States
}

\author{
By Todd M. Preston, ${ }^{1}$ Joanna N. Thamke, ${ }^{2}$ Bruce D. Smith, ${ }^{2}$ and Zell E. Peterman ${ }^{2}$
}

\section{Overview}

This chapter describes field investigations examining produced water (brine) contamination of surface water and shallow groundwater resources at three study sites within the Prairie Pothole Region (PPR) and Williston Basin. Previous research on brine contamination was performed at two of these sites by the Montana Bureau of Mines and Geology (MBMG) or the U.S. Fish and Wildlife Service (USFWS), and results from these studies are presented with recent U.S. Geological Survey (USGS) results to examine the temporal changes in brine contamination. In order to better discuss the results from these multiple studies, information on brine chemistry in the Williston Basin, sources of brine contamination, identification of brine contamination, as well as descriptions of the three study sites and previous research are presented in the "Introduction." The "Data-Collection Methods" section describes the collection and analysis of water-quality and geophysical data. The "Data Results" section lists the published sources for all data from the water-quality sample analyses and geophysical surveys. The "Study Sites Results and Discussion" describes the extent and magnitude of brine contamination at each of the three study sites based on these data, as well as provides information on the fate and transport of brine contamination in geologic settings common to the PPR of the Williston Basin.

\section{Introduction}

The Williston Basin is located in the Northern Great Plains (fig. B-1) and has been a leading domestic oil and natural gas producing region for more than one-half a century. Rapid oil and gas development is currently occurring from deep formations such as the Bakken and Three Forks Formations to meet current and future energy needs. Large volumes of brine, defined as very saline water with greater than 35,000 milligrams per liter ( $\mathrm{mg} / \mathrm{L})$ of total dissolved solids (TDS) (Kalkhoff, 1993), are produced along with the oil. Saline

${ }^{1}$ Parallel, Inc.

${ }^{2}$ U.S. Geological Survey drilling fluids are also composed of halite and other minor salts and are often used to prevent the dissolution of numerous evaporite beds, which are encountered while drilling deep oil and gas wells in the Williston Basin. Brine and drilling fluids have historically been placed in reserve pits and ponds or disposed of through injection wells into deep formations. Handling, storage, and disposal of brine in the Williston Basin have resulted in contamination of surface water and groundwater resources (Murphy, 1983; Murphy and Kehew, 1984; Beal and others, 1987; Murphy and others, 1988; Reiten and Tischmak, 1993; Thamke and Craigg, 1997; Peterman and others, 2010; Preston and others, 2013; Rouse and others, 2013). Brine contamination from produced waters and drilling fluids often results in marked changes in the chemistry of surface water and groundwater (Reiten and Tischmak, 1993). These changes can affect primary productivity in aquatic systems, degrade and destroy domestic and stock water resources, and cause declines in crop production or loss of arable acreage.

Geology and climate often control the length and extent of contamination, unless remediation action is taken. For example, at an oilfield in Alabama, highly permeable sediments and high precipitation rapidly decreased brine contamination in groundwater during a 10-year period (Powell and others, 1973). However, in the semiarid PPR, which is predominately underlain by relatively low permeability clayrich tills, contamination from the 1960s is still evident and is expected to persist for tens to hundreds of years (Murphy and others, 1988; Preston, 2011).

\section{Brine Chemistry in the Williston Basin}

The brine chemistry of an individual deep formation in the intracratonic Williston Basin is influenced by the origin of the brine, subsequent diagenetic processes, and regional and local hydrogeology (Iampen and Rostron, 2000; Warren, 2010). Local and basinwide variations affect the subsurface spatial distribution of brine chemistry. Three pre-Mississippian brine zones, developed in response to basinwide, topographically controlled groundwater flow initiated by Laramide uplifts to the west (Bachu and Hitchon, 1996), can be differentiated in the Williston Basin based on major-ion chemistry (Iampen and Rostron, 2000). The recharge zone, located along the western 


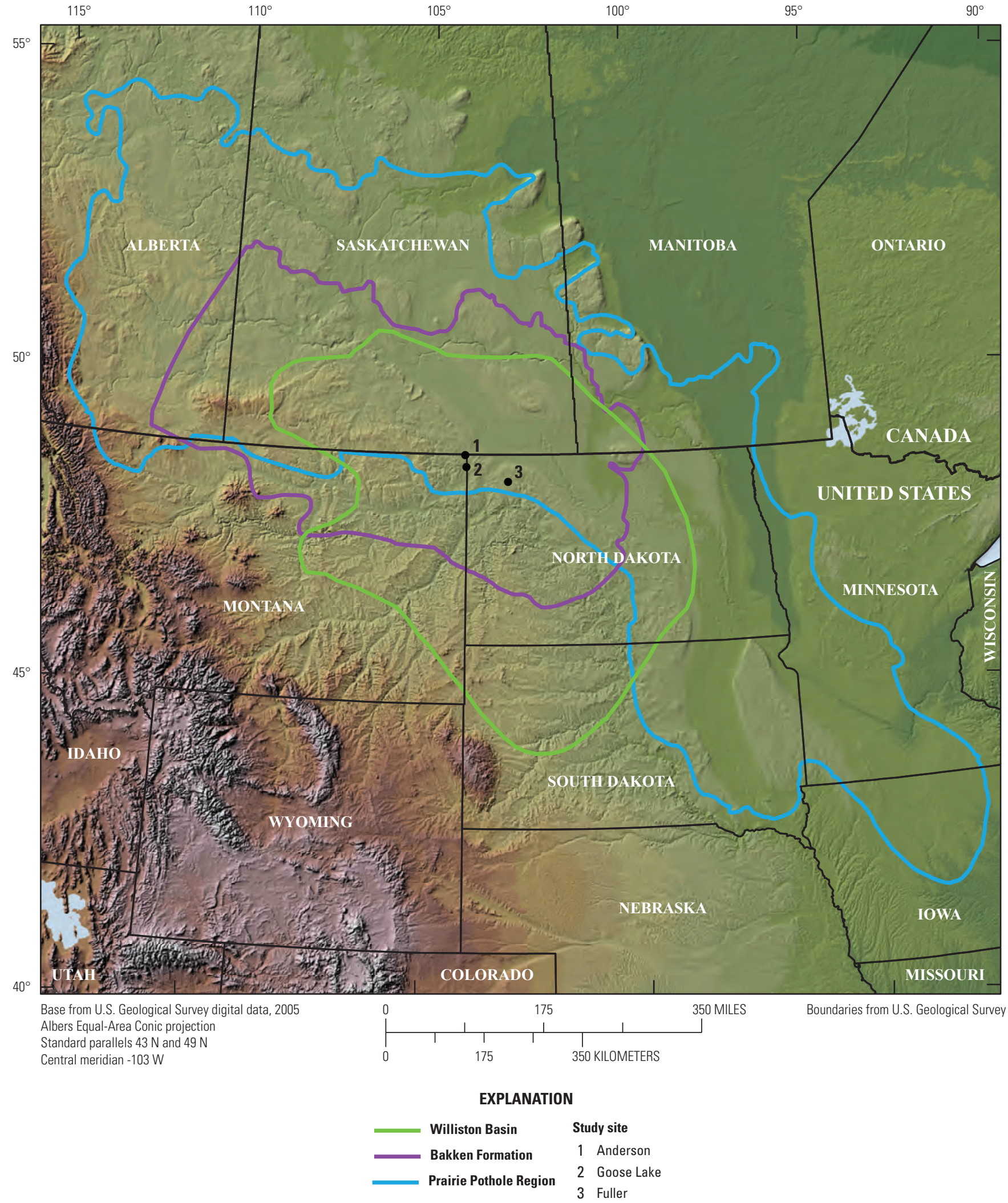

Figure B-1. Location of the three study sites and the extent of the Williston Basin, Bakken Formation, and the Prairie Pothole Region. 
edge of the Williston Basin, is brackish calcium $\left(\mathrm{Ca}^{2+}\right)$-sulfate $\left(\mathrm{SO}_{4}^{2-}\right)$ dominated water with average TDS values less than $30,000 \mathrm{mg} / \mathrm{L}$. The central zone is a slow moving to stagnant sodium $\left(\mathrm{Na}^{+}\right)-\mathrm{Ca}^{2+}$-chloride $(\mathrm{Cl})$ brine with anomalously low $\mathrm{SO}_{4}^{2-}$ and TDS values greater than $300,000 \mathrm{mg} / \mathrm{L}$. The northern zone is $\mathrm{Na}^{+}-\mathrm{Cl}^{-}$brine with TDS values between 100,000 and $200,000 \mathrm{mg} / \mathrm{L}$ (Iampen and Rostron, 2000). Unlike many other intracratonic basins, oxygen and hydrogen isotopic compositions in pre-Mississippian Williston Basin brines do not systematically increase with depth (Rostron and Holmden, 2003). Much of the oil and gas production in the Williston Basin occurs within the stagnant groundwater-flow system in the central zone and produced waters are extremely saline. Iampen and Rostron (2000) documented an average TDS concentration of $300,000 \mathrm{mg} / \mathrm{L}$ from 50 actively producing oil wells, with some samples exceeding $380,000 \mathrm{mg} / \mathrm{L}$.

\section{Sources of Brine Contamination}

The primary source of brine contamination throughout the Williston Basin appears to be from historical storage and disposal of brine and drilling mud in unlined reserve pits that were prone to seepage (Murphy, 1983; Murphy and Kehew, 1984; Beal and others, 1987; Reiten and Tischmak, 1993; Rouse and others, 2013). Reserve pits were typically excavated at each oil well site to separate drilling mud and cuttings as well as to store and evaporate brine. The average reserve pit measured 46 meters $(\mathrm{m})$ long by $18 \mathrm{~m}$ wide by $3 \mathrm{~m}$ deep and contained between 1,529 and 2,549 cubic meters $\left(\mathrm{m}^{3}\right)$ of saltsaturated drilling fluid (Murphy and Kehew, 1984). In addition to reserve pits, other potential sources of brine contamination could include uncontained discharges (dumping), injection well failures, corrosion of abandoned production and injection well casings, and breaks in pipelines that transport oil and brine to treatment and injection facilities (Reiten and Tischmak, 1993; Thamke and Craigg, 1997; Preston, 2011). While the majority of contamination documented to date appears to be from preexisting reserve pits, the potential exists for new releases of brine and oil in the PPR, with contamination from these releases likely to increase because of the rapid development of the Bakken and Three Forks Formations and aging oilfield infrastructure. For example, 1,696 incidents involving the release of oil, brine, or other contaminants were reported to the North Dakota Department of Health between November 1, 2012, and November 11, 2013. Of these incidents, 1,305 were contained releases that remained within the boundaries of the production or exploration facility, and 391 were uncontained releases that overflowed the boundaries of the facility or leaked from a facility pipeline (North Dakota Department of Health web site, accessed January 2014, at $h t t p: / / w w w$. ndhealth.gov/ehs/spills/).

The rate of brine movement from abandoned, unlined reserve pits depends on the initial quantity of salt produced at a given site, hydraulic conductivity of the sediments, topography, and precipitation (Murphy and others, 1988). The average reserve pit is estimated to contain 236 megagrams of salt derived from produced waters and drilling muds upon burial (Reiten and Tischmak, 1993). Soluble salts and exchangeable $\mathrm{Na}^{+}$ions were the main constituents added to drilling mud and are the most detrimental to plants and soils (Moseley, 1983). The hydraulic conductivity of glacial sediments varies considerably depending on the type of material (glacial outwash compared to glacial till) and can range from $1.2 \times$ $10^{-3}$ to $1 \times 10^{-12}$ meters per second $(\mathrm{m} / \mathrm{s})$ (Schwartz and Zhang, 2003). Investigations of brine contamination from an oilfield site within glacial till sediments in North Dakota determined that pore waters within the saturated and unsaturated zones below reserve pits abandoned for 10 to 25 years had the same ionic composition as the waters contained in the reserve pits (Murphy and others, 1988). $\mathrm{Cl}^{-}$ions move significantly slower than the average groundwater-flow velocity in fractured till because of diffusion of the solutes into the porous media of the till (Grisak and others, 1980). Average annual precipitation in the Williston Basin is small, and major recharge events are limited, which results in minimal natural flushing of brine contamination. As a result, it is estimated that brine contamination from reserve pits in the Williston Basin will persist for tens to hundreds of years (Murphy and others, 1988; Preston, 2011).

Strategies for the storage and disposal of brine and drilling fluids in the Williston Basin have changed through time with the recognition of the environmental damage caused by historic construction and reclamation processes of evaporation and reserve pits (Murphy and Kehew, 1984). Although the regulations pertaining to reserve pits are determined by each individual state and province, the general practices and timing of environmental regulations were likely similar across much of the Williston Basin; therefore, the focus of the following discussion is only on reserve pits in North Dakota. The majority of the older reserve pits were constructed without any lining because prior to 1974, the Oil and Gas Regulatory Division of the North Dakota Industrial Commission did not have the authority to require the use of an artificial or synthetic liner (Beal and others, 1987); but, after 1974, liners were often only required if the reserve pit was located in permeable sediments (for example, glacial outwash deposits). The use of plastic liners was not mandated until 1982 or 1983 (Cody VanderBusch, Reclamation Specialist, North Dakota Industrial Commission Department of Mineral Resources Oil and Gas Division, written commun., March 4, 2013).

Just as construction practices have changed through time, so have reclamation processes. However, in most onsite pit reclamation scenarios, the low viscosity liquid is first pumped out for reuse in another well or transported to an injection well, leaving behind a saline slurry, which is then buried. During reclamation in the 1950s and 1960s, excavated materials were gradually added from the sides of the pit, covering the remaining slurry. Because of the small area of the reserve pit and inability of the fluids to desiccate rapidly, pit reclamation could take anywhere from 1 month to 1 year. More recently, unlined and plastic-lined reserve pits were often reclaimed by the trenching method, which greatly reduced the time required 
for reclamation. In this method, trenches were dug that emanated from the reserve pit, and excavated material was added from the side, forcing the saline slurry to drain outward into the unlined trenches where it was then buried (Beal and others, 1987). The use of trenching for pit reclamation was discontinued by 1992 or 1993 (Cody VanderBusch, Reclamation Specialist, North Dakota Industrial Commission Department of Mineral Resources Oil and Gas Division, written commun., March 4, 2013). In unlined and trenched reserve pits, the buried saline slurry is in direct contact with the underlying sediments and capable of leaching into the shallow groundwater system. Once trenching was discontinued, reclamation of reserve pits in North Dakota required the plastic liner to be folded over the reserve pit and then capped with clay; however, the liners could be ripped or punctured as they are manipulated with heavy machinery.

Alternative strategies to the use of reserve pits to store brine and drilling fluids are available and are now required in the North Dakota portion of the Williston Basin. Reserve pits (now called drilling pits) can only accept solid or stabilized fly-ash drill cuttings and no liquids as of April 2012 (North Dakota Oil and Gas Division, 2013). These rules apply to all wells drilled deeper than $1,524 \mathrm{~m}$ and include all the major oil producing units such as the Bakken and Three Forks Formations. Tanker trucks replace the reserve pit during these "pitless" drilling operations and perform the separation of drilling fluids and cuttings, which can allow for the recycling of the drilling mud. The use of "pit-less" drilling eliminates one of the most pervasive potential sources of brine contamination in the Williston Basin.

\section{Identification of Brine Contamination}

Several methods have been used to identify brine contamination to surface water and shallow groundwater resources within the Williston Basin. Geochemical methods are useful because brine often alters salinity and strontium isotope ratios in surface water and shallow groundwater. Geophysical methods are used to determine increases in the electromagnetic conductance of soil and shallow groundwater from brine. These methods were integral in determining the presence and magnitude of brine contamination at the three study sites described in this report.

\section{Salinity}

The salinity of surface water and shallow groundwater in the PPR is distinctly different than the salinity of deep formational groundwater produced during oil and gas development. The water quality of surface water and shallow groundwater is often controlled by the hydrologic position within the landscape, with TDS generally increasing from areas of recharge to areas of discharge (Swanson and others, 2003). Consequently, surface water and shallow groundwater in discharge areas are often enriched in $\mathrm{SO}_{4}^{2-}$ and bicarbonate and depleted in $\mathrm{Cl}^{-}$, resulting in $\mathrm{SO}_{4}^{2-}$ and carbonate dominated water (Custer, 1976). In contrast, deep formational groundwater in the Williston Basin (brine) is enriched in $\mathrm{Cl}^{-}$and $\mathrm{Na}^{+}$. Although TDS values can be large in surface water and shallow groundwater, as well as in the deep formational groundwater, the differences in major-ion chemistry allow for identification of surface water and shallow groundwater contaminated by brine.

Uncontaminated and brine-contaminated surface water and shallow groundwater can be quickly and easily distinguished in northeastern Montana by using a rapid assessment method developed by Reiten and Tischmak (1993). This rapid assessment method uses a contamination index (CI) that is defined as the ratio of $\mathrm{Cl}^{-}$concentration in milligrams per liter to specific conductance in microsiemens per centimeter $(\mu \mathrm{S} /$ $\mathrm{cm}$ ) in a water sample. The CI allows for field or laboratory determination of $\mathrm{Cl}^{-}$contamination in waters ranging from fresh to extremely saline. Additionally, CI values remain relatively stable in groundwater wells that develop vertical density gradients. Surface water and shallow groundwater with a CI value greater than 0.035 was empirically determined to be contaminated by brine in eastern Sheridan County, Mont. (Reiten and Tischmak, 1993; Jon Reiten, Senior Research Professor/Hydrogeologist, Montana Bureau of Mines and Geology, written commun., August 13, 2013); however, this value likely varies throughout the Williston Basin depending on background $\mathrm{Cl}^{-}$concentrations, local soil conditions, precipitation, and evapotranspiration. Two of the three study sites discussed in this chapter are located in eastern Sheridan County, Mont., and the other is located approximately 75 kilometers $(\mathrm{km})$ to the east in Williams County, N. Dak., where soil types and precipitation and evapotranspiration rates are similar. Therefore, the use of the 0.035 value to indicate brine contamination is considered applicable at all three study sites.

\section{Strontium Isotopes}

Strontium ( $\mathrm{Sr}$ ) isotopes can be used to identify the presence of small amounts of brine (Peterman and others, 2010). Strontium is an alkaline-earth element closely following $\mathrm{Ca}^{2+}$ in the geochemical cycle with a $\mathrm{Ca}^{2+} / \mathrm{Sr}$ ratio of about 100 to 200 in most surface water and shallow groundwater and approximately 30 in saline formation waters. The strontium- 87 isotope $\left({ }^{87} \mathrm{Sr}\right)$ is the daughter of rubidium- 87 through beta decay with a half-life of about 49 billion years. The relative abundance of the other isotopes, strontium- 84 , strontium- 86 $\left({ }^{86} \mathrm{Sr}\right)$, and strontium- 88 , are invariant as they do not fractionate appreciably in nature. Consequently, the ${ }^{87} \mathrm{Sr} /{ }^{86} \mathrm{Sr}$ ratio is an extremely useful parameter for determining water-rock interaction, mixing of waters of different origins, and degree of hydrologic isolation among units (for example, cross flow and stratigraphic compartmentalization).

Values of ${ }^{87} \mathrm{Sr} /{ }^{86} \mathrm{Sr}$ in past and present sea water are well known (McArthur and others, 2001). Saline formation waters were likely formed by evaporation of seawater, dissolution of evaporates, or long-term water-rock interaction (Kharaka and Hanor, 2003). Surface water and shallow groundwater in the 
PPR will dissolve Sr from the near-surface rocks and unconsolidated material. The Late Cretaceous Bearpaw/Pierre Shale, which occurs throughout the Williston Basin, has an average ${ }^{87} \mathrm{Sr} /{ }^{86} \mathrm{Sr}$ value of $0.7150 \pm 0.0050$ (U.S. Geological Survey, unpub. data, 2013). The overlying Late Cretaceous sandstones and Early Tertiary rocks likely would have even larger values because of detritus derived in part from Precambrian source rocks fluvially transported from the west and southwest. Glacial deposits in the northern part of the Williston Basin likely will have elevated ${ }^{87} \mathrm{Sr} /{ }^{86} \mathrm{Sr}$ ratios because of a component of crystalline rock derived from the Canadian Shield located to the northeast. In addition to unique ${ }^{87} \mathrm{Sr} /{ }^{86} \mathrm{Sr}$ signatures, brines in the Williston Basin have very large $\mathrm{Sr}$ concentrations typically up to $1,000 \mathrm{mg} / \mathrm{L}$ or more (Peterman and others, 2012). Thus, exceedingly small amounts of brine in surface water and shallow groundwater in the PPR of the Williston Basin can be detected with $\mathrm{Sr}$ isotopes.

\section{Electromagnetic Properties}

Electromagnetic (EM) surveys measure the cumulative electrical properties of pore water and the soil matrix and are capable of detecting differences in salinity in the saturated and vadose zones. The basic operation of EM instrumentation involves two coils, a transmitter and receiver coil, separated by a known distance. The transmitter coil is energized with an alternating current, inducing small currents in the earth, which in turn create a secondary magnetic field. The receiver coil senses the primary and secondary magnetic fields and converts the time-varying signals into electrical conductivity. Electromagnetic readings are expressed as apparent conductivity, which is an integration of all the subsurface material sensed by the equipment. Enhanced subsurface characterization is obtained by changing the dipole orientation or the coil spacing, resulting in different depth integration curves and exploration depths (McNeill, 1980). However, the effective exploration depth decreases for all EM equipment as the conductivity of the medium decreases (Greenhouse and Slaine, 1986).

Saline groundwater will have larger apparent conductivity than fresh groundwater in electromagnetic surveys (Reiten and Tischmak, 1993; Thamke and Craigg, 1997). Textural composition, soil saturation, and water salinity can affect apparent conductivity values, with increasing clay, water content, and salinity causing increasing apparent conductivity. However, in the semiarid climate of northeastern Montana, soil salinity is likely the most dominant variable contributing to apparent conductivity (Corwin and Lesch, 2005). In areas of similar clay and water content, the salinity of groundwater and soil primarily affects apparent conductivity values (Reiten and Tischmak, 1993). Naturally saline and brine-contaminated groundwater and soil can both result in elevated apparent conductivity, so the availability of groundwater chemistry data is important to differentiate between the two types of salinity.

\section{Study Sites and Previous Research}

The PPR was formed by Pleistocene glaciations, and the three study sites were selected to represent the primary glacial deposits within the PPR (fig. B-1). Additionally, the selection of study sites was based on proximity to Federal lands, presence of oilfield activity, and previous research that indicated brine contamination. In-depth surficial geology was determined from maps produced by Reiten and Tischmak (1993) of eastern Sheridan County, Mont., that delineated areas of glacial till, glacial outwash, and glaciolacustrine deposits. The Goose Lake site represents coarse-grained, glacial outwash deposits within and adjacent to a USFWS Waterfowl Production Area (WPA). Several oil-production wells and a tank battery (a collection of storage tanks designed to separate oil and brine) are within the Goose Lake site. Research at the Goose Lake site began in 1989. The Anderson site represents clay-loam glacial till deposits within a WPA. There are several oil-production wells and a tank battery within the Anderson site. Research at the Anderson site began in 2004. Analysis of the eastern Sheridan County surficial geology map failed to identify a site with oilfield activity within glaciolacustrine deposits; therefore, the search was expanded to western North Dakota. The Fuller site was identified from surficial geology maps produced by the North Dakota Geological Survey and represents silt and clay glaciolacustrine deposits within and adjacent to a WPA. The Fuller site contains an oil-production well and a tank battery. No previous research had been conducted at the Fuller site. All three study sites are located in the Missouri Coteau portion of the PPR.

\section{Goose Lake Study Site}

Potential sources of brine to surface water and shallow groundwater resources at the Goose Lake site consist of two active (during 2009) and six abandoned oil wells and associated reserve pits, transport lines, and a tank battery. A transport line, located along the northern section line that leads to the tank battery, ruptured in 2006 and discharged an unknown volume of oil and brine onto the land surface.

Glacial stagnation processes have resulted in an approximately $5 \mathrm{~m}$ thick undulating blanket of moderately well sorted to very poorly sorted silty sand and gravel outwash deposits that overlie a basal confining bed of relatively impermeable, pebbly clay loam (till). Additionally, there are locally interbedded and mantling deposits of silt and clay from glacial and modern lacustrine environments (Reiten and Tischmak, 1993). The outwash deposits are saturated beneath the modern drainages and wetlands and are unsaturated below topographic rises, creating unconfined aquifer conditions in the saturated outwash deposits (Reiten and Tischmak, 1993).

In total, the Goose Lake study site includes 39 monitoring wells and 19 wetlands where field parameters or water samples were collected during 1988, 1989, 1990, 2004, 2005, 2006, 2009, or 2011. The MBMG installed 35 monitoring wells, the USFWS installed two wells in 2005, and the USGS 
installed two additional wells in 2011 for a separate study. All monitoring wells are located near potential sources of brine or along potential groundwater-flow paths. A sample of the produced waters was collected from the tank battery in 2009 . All water-quality samples were analyzed for major ions and a subset of samples were analyzed for trace elements and $\mathrm{Sr}$ isotopes. Discussion of water-quality samples collected at the Goose Lake study site will focus solely on 18 monitoring wells and 11 wetlands sampled by the MBMG $(1988,1989$, or 1990) or the USFWS $(2004,2005$, or 2006), as well as the USGS (2009).

\section{Anderson Study Site}

Potential sources of brine contamination in surface water and shallow groundwater resources at the Anderson site consist of five active and abandoned oil wells and associated reserve pits, transport lines, and a tank battery within the Anderson WPA. Additionally, there are six active and abandoned oil wells with associated reserve pits and another tank battery adjacent to the WPA.

Glacial stagnation processes have resulted in a layer of clay-rich pebbly loam (glacial till), at least $13 \mathrm{~m}$ thick at the deepest groundwater-monitoring well, and underlying much of the Anderson study site. In some parts of the study site, the till is mantled by moderately well sorted to very poorly sorted silty sand and gravel outwash deposits, or glaciolacustrine sediments. However, all groundwater-monitoring wells are completed in glacial till. As with the majority of glacial tills in the PPR, the till at the Anderson study site is unsaturated and oxidized in the near surface and saturated and unoxidized at depth.

In total, the Anderson study site includes 15 monitoring wells and 10 wetlands where field parameters or water samples were collected during 2004, 2005, 2010, or 2011. The MBMG and USFWS installed 13 monitoring wells during 2004, and the USGS installed two monitoring wells in 2011 for a separate study. All monitoring wells are located adjacent to potential sources of brine or along potential groundwaterflow paths. A sample of the produced waters was collected from the tank battery in 2010. All water-quality samples were analyzed for major ions, and a subset of samples were analyzed for trace elements and $\mathrm{Sr}$ isotopes. Discussion of the Anderson site water-quality data focuses solely on analytical results from 10 monitoring wells and 5 wetlands sampled by the USFWS (2004 or 2005) and the USGS (2010).

\section{Fuller Study Site}

Potential sources of brine to surface water and shallow groundwater resources at the Fuller study site consist of one abandoned oil well and associated reserve pit, transport lines, and a tank battery. Additionally, there are several active and abandoned oil wells and associated reserve pits located upgradient from the sampled sites.
Glacial stagnation processes at the Fuller study site have resulted in collapsed lake plain deposits within a low-relief ground moraine. The lake plain, or glaciolacustrine deposits, consist primarily of silt and clay that are at least $2 \mathrm{~m}$ thick at the deepest groundwater-monitoring well. The surrounding ground moraine consists primarily of till. Both monitoring wells were completed in the shallow glaciolacustrine deposits.

The Fuller study site includes two monitoring wells, a reservoir, a wetland below the reservoir, and three oil-production wells that were sampled during 2010. Two temporary monitoring wells were installed and sampled by the USGS during June 2010 along potential groundwater-flowpaths downgradient from potential sources of brine contamination. The well casings were removed, and the boreholes were filled by the USGS in late summer 2010. Water-quality samples were collected from a reservoir upgradient and a wetland downgradient from the tank battery adjacent to the Fuller WPA. Water-quality samples also were collected during 2010 from the tank battery adjacent to the WPA as well as two additional oil/brine separation tanks in close proximity to the WPA that receive oil and brine from wells producing from the Bakken Formation. Water samples were analyzed for major ions, trace elements, and $\mathrm{Sr}$ isotopes.

\section{Data-Collection Methods}

\section{Water Quality}

Surface-water and groundwater sample-collection methods used by the USGS during 2009-10 are described in Preston and others (2012) and summarized below. Water-quality data from three different time periods and studies are presented in this chapter: 1989 research by the MBMG, 2004-6 research by the MBMG and USFWS, and 2009-10 research by the USGS. The MBMG analytical procedures follow U.S. Environmental Protection Agency methods for inorganic constituent analysis (J. LaFave, Senior Research Hydrogeologist, Montana Bureau of Mines and Geology, oral commun., May 1, 2009). Samples submitted to the USGS National Water Quality Laboratory (NWQL) were analyzed using the methods described by Fishman (1993) for major ions, selected trace elements, and iodide and bromide. Strontium isotope analyses were performed during 2009-10 at the USGS Yucca Mountain Project Branch Strontium Isotope Laboratory (now USGS Crustal Geophysics and Geochemistry Center's Strontium Isotope Laboratory) using methods summarized by Peterman and others (1985).

The accuracy of laboratory determined $\mathrm{Cl}^{-}$concentrations and specific conductance values from MBMG's Analytical Laboratory are reported to be within 10 percent, but variability could be as high as 20 percent because of dilution (Steve McGrath, Organic Chemist, Montana Bureau of Mines and Geology Analytical Laboratory, written commun., May 1, 2009). Similarly, measurement accuracies were likely within 
5 percent for water samples analyzed at the NWQL. This accuracy estimate is based on data from the USGS Branch of Quality Systems inorganic blind sample program, which continuously runs double blind, environmental matrix based (from natural water samples as opposed to a deionized water based synthetic matrix samples) samples with known concentrations on most of the analytical equipment at NWQL. For example, during June 2009, when water samples from the Goose Lake study site were analyzed, the maximum standard errors for $12 \mathrm{Cl}^{-}$and 14 specific conductance blind samples were 4.9 and 4.0 percent, respectively (data available from $h t t p: / / b q s$. usgs.gov). Similar errors were reported for the timeframes when samples from the Anderson and Fuller study sites were analyzed.

Field measurements were made at numerous wetlands at the Goose Lake site throughout 1989-90 and 2004-5 and at the Anderson site throughout 2004-5. Field data were collected using the same procedures and equipment in 1989-90 and 2004-5 with $\mathrm{Cl}^{-}$concentrations determined using QuanTab Cl- Titrators, numbers 1175 (range 60-480 parts per million [ppm] $\mathrm{Cl}^{-}$) or 1176 (range $300-6,000 \mathrm{ppm} \mathrm{Cl}^{-}$), and specific conductance determined with a YSI Model 30 probe. Parts per million is equivalent to milligrams per liter for pure water at 3.89 degrees Celsius (Hem, 1985) and can be used only as a general comparison to milligrams per liter for all other waters. $\mathrm{Cl}^{-}$concentrations ranging from 60 to $6,000 \mathrm{ppm}$ were read directly from the titrator strip, while samples with higher $\mathrm{Cl}^{-}$concentrations required dilution with deionized water. Field $\mathrm{Cl}^{-}$concentrations and specific conductance data were used to estimate $\mathrm{CI}$ values when water samples were not submitted to an analytical laboratory.

\section{Geophysical Surveys}

Complete descriptions of geophysical data-collection methods and apparent conductivity measurements are provided in Preston and others (2012) and summarized below. Geophysical data presented in this chapter are from surveys performed with a Geonics EM-31 by the MBMG and the USFWS during 2004 and a Geonics EM-31, Geonics EM-34, and a Geophex GEM-2 by the USGS during 2009-10. The apparent conductivity data required spatial interpolation for visual display using ArcGIS 9.3.1 for the EM-31 and EM-34 data and GEOSOFT Oasis for the GEM-2 data. Spatial interpolation in ArcGIS 9.3.1 was performed using the inverse distance weighting function on a neighborhood of three points and default power of two. Spatial interpolation in GEOSOFT Oasis was performed using minimum curvature. The spatially interpolated surface created in ArcGIS 9.3.1 is a rectangle with dimensions based on the furthest data points in each cardinal direction. Therefore, to provide data only in areas with sufficient geophysical control, these spatially interpolated surfaces were clipped to buffers created around the measurement points. All buffers were between 25 and $75 \mathrm{~m}$.

\section{EM-31}

A Geonics EM-31 was used to measure apparent conductivity and delineate the lateral extent of brine-contaminated groundwater plumes (referred to as brine plumes hereafter) at all three study sites. All EM-31 surveys were performed in the vertical dipole mode, which has an exploration depth of approximately $6 \mathrm{~m}$. EM-31 surveys were conducted at the Goose Lake study site in July 2004 and September and October 2009. Surveys were also performed at the Goose Lake study site by the MBMG in 1989, but the original data has been lost and attempts to georectify the images in Reiten and Tischmak (1993) proved unsuccessful. At the Anderson study site, EM-31 surveys were performed in July and September 2004 and October 2010. The EM-31 surveys at the Fuller study site were performed in October 2010. No previous geophysical surveys had been performed at the Fuller site for comparison with the 2010 survey.

Background apparent conductivities were determined from several (greater than 15) measurements in areas upgradient from oilfield facilities at each study site during all years. Apparent conductivity values less than approximately 30 millisiemens per meter $(\mathrm{mS} / \mathrm{m})$ are considered representative of background conductivity at the Goose Lake and Anderson study sites. Background apparent conductivity values were slightly higher at the Fuller study site, in the range of 25-50 $\mathrm{mS} / \mathrm{m}$, with the higher values likely because of the greater clay content of the glaciolacustrine deposits.

\section{EM-34}

A Geonics EM-34 was used in September 2009 to measure apparent conductivity, characterize the three-dimensional geometry of brine plumes, and examine the potential for stratigraphic controls on the transport of contaminated groundwater at the Goose Lake study site. Apparent conductivity measurements were collected at 10-, 20-, and 40-m intercoil spacings in the horizontal and vertical dipole orientations. Exploration depths in the horizontal dipole orientation for the 10-, 20-, and 40-m intercoil spacings are 7.5, 15, and $30 \mathrm{~m}$, respectively. Respective exploration depths for the vertical dipole orientation are 15, 30, and $60 \mathrm{~m}$; however, the horizontal dipole mode receives the majority of the signal from immediately below the land surface compared to roughly 0.4 times the intercoil spacings in the vertical dipole mode (McNeill, 1980). Therefore, even though the exploration depths may be equal, the horizontal dipole mode receives much more of its signal from shallower depths in the subsurface relative to the vertical dipole mode.

Background apparent conductivity measurements for all dipole orientations and intercoil spacing combinations were determined from several (greater than 10) measurements in areas upgradient from oilfield facilities. In the horizontal dipole orientation, measurements below approximately 20 , 25 , and $40 \mathrm{mS} / \mathrm{m}$ are considered representative of background conductivity for the 10-, 20-, and 40-m intercoil spacings, 
respectively. In the vertical dipole orientation, measurements below approximately 25,35 , and $40 \mathrm{mS} / \mathrm{m}$ are considered representative of background conductivity for the 10-, 20-, and $40-\mathrm{m}$ intercoil spacings, respectively.

\section{GEM-2}

A Geophex GEM-2 was used in October 2010 to measure apparent conductivity, characterize the three dimensional geometry of brine plumes, and examine the potential for stratigraphic controls on the transport of contaminated groundwater at the Anderson and Fuller study sites. Apparent conductivity measurements were collected from seven frequencies; however, only the results from three frequencies (93,030, 47,970, and 1,530 hertz [Hz]) that span the range of exploration depths are presented in this chapter. Exploration depths for the 93,030, 47,970, and 1,530 Hz frequencies are 2, 4 , and $7 \mathrm{~m}$, respectively.

Background conductivity at each frequency was determined as the mean value from the survey data. The respective background conductivity values for 93,030, 47,970, and 1,530 $\mathrm{Hz}$ frequencies were 114,150 , and $140 \mathrm{mS} / \mathrm{m}$, respectively, at the Anderson study site and 86,109 , and $101 \mathrm{mS} / \mathrm{m}$, respectively, at the Fuller study site.

\section{Data Results}

Results for the various studies discussed in this chapter are published in several sources described below. For the Goose Lake study site, field parameters and analytical results for all water samples are available from the following sources: MBMG samples collected during 1988, 1989, or 1990 in Reiten and Tischmak (1993), USFWS samples collected during 2004, 2005, or 2006 in Rouse and others (2013), and USGS samples collected during 2009 in table 1-1 of Preston and others (2012). Geophysical data collected by the USFWS in 2006 and by the USGS in 2009 are located in table 1-4 of Preston and others (2012).

For the Anderson study site, field parameters and analytical results for all water samples are available from the following sources: USFWS samples collected during 2004 or 2005 in Rouse and others (2013) and USGS samples collected during 2010 in table 1-2 of Preston and others (2012). Geophysical data collected by the USFWS in 2004 and by the USGS in 2010 are located in table 1-4 of Preston and others (2012).

Analytical results for water samples collected by the USGS in 2010 at the Fuller study site are located in table 1-3 of Preston and others (2012). Geophysical data collected by the USGS in 2010 are located in table 1-4 of Preston and others (2012).

In order to facilitate the following discussion, summary water-quality data containing site name, $\mathrm{Cl}^{-}$concentration, specific conductance, $\mathrm{Na}^{+} / \mathrm{Cl}^{-}$molar ratio, and $\mathrm{CI}$ values are presented for the Goose Lake study site (table B-1), the Anderson study site (table B-2), and the Fuller study site (table B-3).

\section{Study Sites Results and Discussion}

In the following discussion and accompanying figures, the names of individual oil wells at the three study sites are identified by the "unique well identifier" number from the American Petroleum Institute (API) well number. API numbers are in the following format 11-222-33333-44-55 with the first two digits being the State code, the next three being the county code, the five-digit number in the middle being the unique well identifier, the next two digits being the directional side track code, and the last two digits being the event sequence code. The State and county codes for Sheridan County, Mont., and Williams County, N. Dak., are 25-091 and 33-105, respectively. Oilfield site numbers used by Reiten and Tischmak (1993) are in parentheses following the API unique well identifier in the discussion of the Goose Lake site. For example, the oil well with the API well number 25091210560000, located in Sheridan County, Mont., and labeled oilfield site 128 by Reiten and Tischmak (1993), is labeled 21056 (128) in this report.

\section{Water Quality}

The quality of surface water and shallow groundwater at the three study sites is highly variable and is dependent on location relative to sources of brine contamination. Sodium, magnesium, bicarbonate, $\mathrm{SO}_{4}{ }^{2-}$, and $\mathrm{Cl}^{-}$are the common dominant ions in uncontaminated and contaminated water at these sites. $\mathrm{Na}^{+}$and $\mathrm{Cl}^{-}$are the dominant ions in the brine. The CI developed by Reiten and Tischmak (1993) using field and analytical $\mathrm{Cl}^{-}$and specific conductivity was used and expanded upon with $\mathrm{Na}^{+}$to identify brine contamination at the three study sites. Figure B-2 shows the distribution of $\mathrm{Na}^{+} / \mathrm{Cl}^{-}$molar ratio, $\mathrm{CI}$ value, and $\mathrm{Cl}^{-}$concentration for 96 samples from tables B-1, B-2, and B-3; 25 samples from Reiten and Tischmak (1993) that were not collected at the Goose Lake study site; 35 samples from Eisenlohr and others (1972); and 21 samples from LaBaugh and Swanson $(1992,2003)$. Samples from Eisenlohr and others (1972) and LaBaugh and Swanson $(1992,2003)$ are in areas with little or no oil development and represent background water-quality conditions for the PPR. Information about the sampled sites was used to select thresholds for water classification. The majority of background samples have CI values below 0.035 (green horizontal line, fig. B-2) and plot to the right of the $1: 1 \mathrm{Na}^{+} / \mathrm{Cl}^{-}$molar ratio (black vertical line, fig. B-2) indicating water chemistry that is dominated by the presence of $\mathrm{Na}^{+}$. In contrast, all but 1 of the 87 water samples with CI values above 0.1 (orange horizontal line, fig. B-2) plot to the left of the $1: 1 \mathrm{Na}^{+} / \mathrm{Cl}^{-}$molar ratio line indicating a distinct shift in the molar ratio towards 


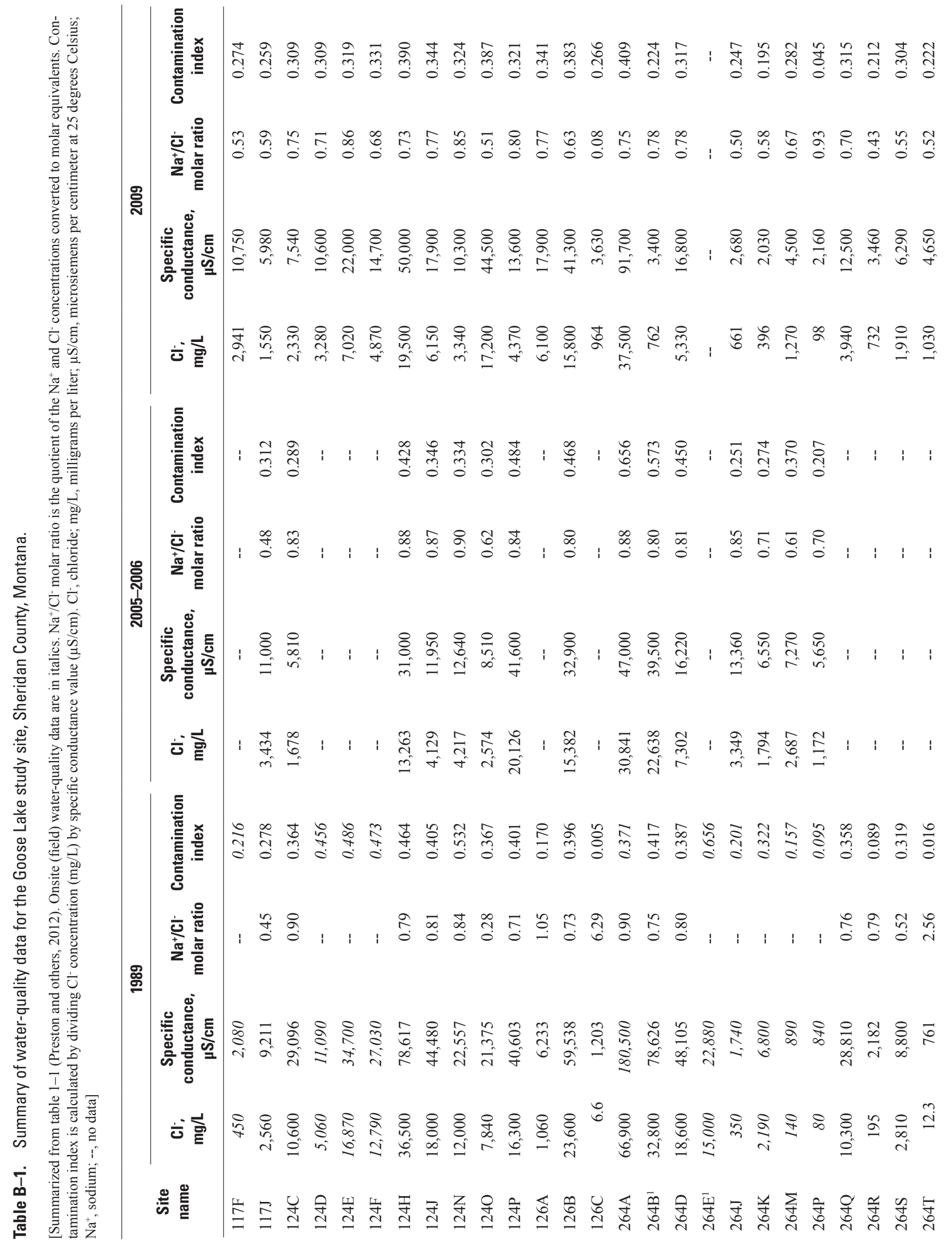




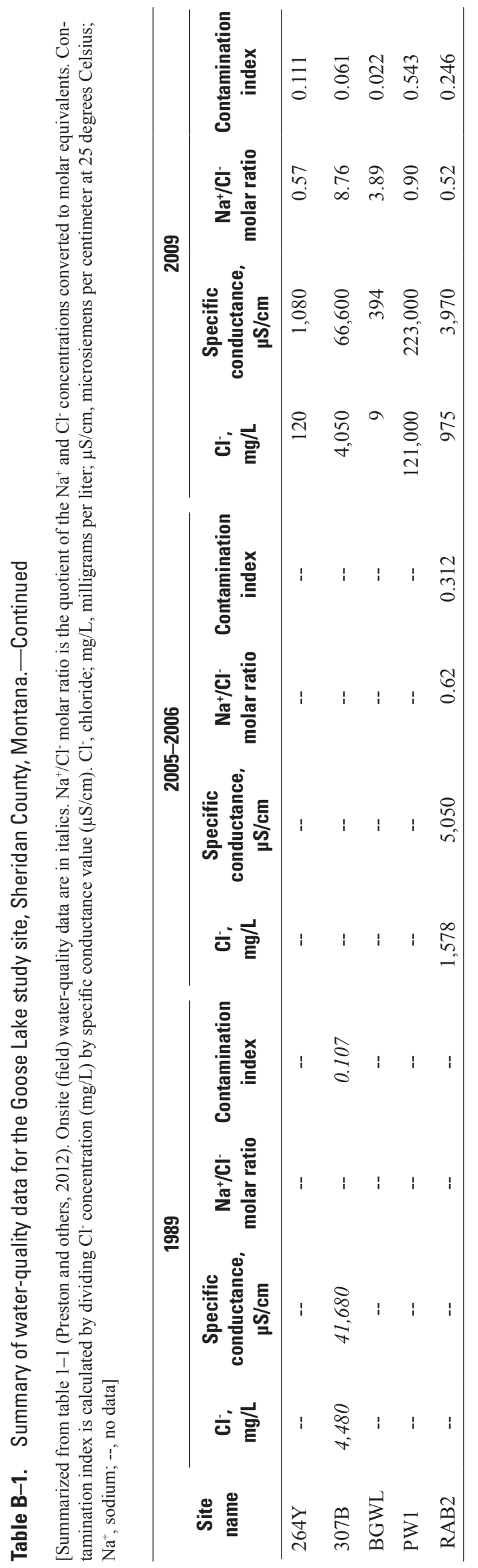

$\mathrm{Cl}^{-}$dominance in water with $\mathrm{CI}$ values above 0.1 and provide strong evidence of brine contamination. It should be noted that 6 of the 18 samples with CI values between 0.035 and 0.1 are in areas with little or no oil development; however, these samples were collected further south and east of the three study sites and, as discussed previously, the higher CI value may be because of regional changes across the PPR and Williston Basin.

To better define the water quality in the PPR, a combination of CI value, $\mathrm{Cl}^{-}$concentration, and $\mathrm{Na}^{+} / \mathrm{Cl}^{-}$molar ratio was used to classify uncontaminated water and three levels of contaminated water (fig. B-2). Uncontaminated water has CI values less than $0.035, \mathrm{Cl}^{-}$concentrations generally less than 250 $\mathrm{mg} / \mathrm{L}$, and $\mathrm{Na}^{+} / \mathrm{Cl}^{-}$molar ratios generally above 1 . Potentially contaminated water has $\mathrm{CI}$ values between 0.035 and $0.1, \mathrm{Cl}^{-}$ concentrations generally less than $10,000 \mathrm{mg} / \mathrm{L}$, and $\mathrm{Na}^{+} / \mathrm{Cl}^{-}$ molar ratios generally less than 10 . Moderately contaminated water has $\mathrm{CI}$ values between 0.1 and $0.35, \mathrm{Cl}^{-}$concentrations generally between 250 and $10,000 \mathrm{mg} / \mathrm{L}$, and $\mathrm{Na}^{+} / \mathrm{Cl}^{-}$molar ratios generally less than 1 . Extremely contaminated water has $\mathrm{CI}$ values greater than $0.35, \mathrm{Cl}^{-}$concentrations generally between 10,000 and $100,000 \mathrm{mg} / \mathrm{L}$, and $\mathrm{Na}^{+} / \mathrm{Cl}^{-}$molar ratios less than 1 . The five brine samples had CI values greater than $0.543, \mathrm{Cl}^{-}$concentrations greater than $109,000 \mathrm{mg} / \mathrm{L}$, and $\mathrm{Na}^{+} /$ $\mathrm{Cl}^{-}$molar ratios less than 1 .

\section{Goose Lake Study Site}

Water was collected during 1989 from monitoring wells $126 \mathrm{C}$ and 264T within the study site and during 2009 from a wetland (BGWL) adjacent to the study site and upgradient from potential brine sources to represent background (CI less than 0.035) water for comparison with water samples that were collected from potentially contaminated wetlands and wells. Background $\mathrm{Cl}^{-}$concentrations were low in samples collected from these three sources and did not exceed $13 \mathrm{mg} / \mathrm{L}$. Nearly all other major-ion and trace-element concentrations in the background water samples were much lower than the concentrations in the contaminated water samples. In 2009, water (PW1) was collected to determine the chemistry of the brine from an oil/brine separation tank located at the tank battery (264) within the study area that receives oil and brine from wells producing from the Ratcliffe Formation.

Monitoring wells with background water samples in 1989 had become moderately contaminated by 2009 (table B-1). Well $126 \mathrm{C}$ is adjacent to a pipeline break that occurred in 2006. In 1989, the $\mathrm{Cl}^{-}$concentration and CI value of water from $126 \mathrm{C}$ were $6.6 \mathrm{mg} / \mathrm{L}$ and 0.005 , respectively. By 2009 , the $\mathrm{Cl}^{-}$concentration and $\mathrm{CI}$ value measured in water from this well were $964 \mathrm{mg} / \mathrm{L}$ and 0.266 , indicating that brine had affected the groundwater quality at this site. Well 264T is along a groundwater-flow path mapped by Reiten and Tischmarck (1993) that flows from the tank battery to West Goose Lake, a large saline lake that occupies a topographically low point and is the likely groundwater discharge area for the Goose Lake study site. The respective $\mathrm{Cl}^{-}$concentration and CI 
Table B-2. Summary of water-quality data for the Anderson study site, Sheridan County, Montana.

[Summarized from table 1-2 (Preston and others, 2012). Onsite (field) water-quality data are in italics. $\mathrm{Na}^{+} / \mathrm{Cl}^{-}$molar ratio is the quotient of the $\mathrm{Na}^{+}$and $\mathrm{Cl}^{-}$concentrations converted to molar equivalents. Contamination index is calculated by dividing $\mathrm{Cl}^{-}$concentration (mg/L) by specific conductance value $(\mu \mathrm{S} / \mathrm{cm})$. $\mathrm{Cl}^{-}$, chloride; $\mathrm{mg} / \mathrm{L}$, milligrams per liter; $\mu \mathrm{S} / \mathrm{cm}$, microsiemens per centimeter at 25 degrees Celsius; $\mathrm{Na}^{+}$, sodium; ,-- no data]

\begin{tabular}{|c|c|c|c|c|c|c|c|c|}
\hline \multirow[b]{2}{*}{$\begin{array}{c}\text { Site } \\
\text { name }\end{array}$} & \multicolumn{4}{|c|}{ 2004-2005 } & \multicolumn{4}{|c|}{2010} \\
\hline & $\begin{array}{l}\mathrm{Cl} \\
\mathrm{mg} / \mathrm{L}\end{array}$ & $\begin{array}{c}\text { Specific } \\
\text { conductance, } \\
\mu \mathrm{S} / \mathrm{cm}\end{array}$ & $\begin{array}{c}\mathrm{Na}^{+} / \mathrm{Cl}^{-} \\
\text {molar ratio }\end{array}$ & $\begin{array}{l}\text { Contamination } \\
\text { index }\end{array}$ & $\begin{array}{l}\mathrm{Cl} \\
\mathrm{mg} / \mathrm{L}\end{array}$ & $\begin{array}{c}\text { Specific } \\
\text { conductance, } \\
\mu \mathrm{S} / \mathrm{cm}\end{array}$ & $\begin{array}{c}\mathrm{Na}^{+} / \mathrm{Cl}^{-} \\
\text {molar ratio }\end{array}$ & $\begin{array}{l}\text { Contamination } \\
\text { index }\end{array}$ \\
\hline A-1MW & 4.59 & 902 & 16.70 & 0.005 & 7.05 & 1,300 & 14.11 & 0.005 \\
\hline A-2MW & 18,770 & 36,800 & 0.92 & 0.510 & 13,600 & 37,300 & 0.96 & 0.365 \\
\hline A-4MW & 4,954 & 13,670 & 0.79 & 0.362 & 3,490 & 13,100 & 0.91 & 0.266 \\
\hline A-8MW & 4,789 & 13,480 & 0.48 & 0.355 & 6,110 & 18,400 & 0.41 & 0.332 \\
\hline A-10MW & 341 & 22,000 & 23.55 & 0.016 & 323 & 29,400 & 34.43 & 0.011 \\
\hline A-11MW & 360 & 24,800 & 21.35 & 0.015 & 798 & 37,900 & 11.62 & 0.021 \\
\hline A-14MW & 43,213 & 52,500 & 0.58 & 0.823 & 56,600 & 115,000 & 0.56 & 0.492 \\
\hline A-15MW & 163 & 23,600 & 60.78 & 0.007 & 133 & 26,600 & 11.59 & 0.005 \\
\hline A-16MW & 10,612 & 21,900 & 0.44 & 0.485 & 23,900 & 56,400 & 0.42 & 0.424 \\
\hline A-17MW & 2,542 & 9,340 & 0.74 & 0.272 & 3,010 & 11,700 & 0.64 & 0.257 \\
\hline AND4 & 31,660 & 68,366 & -- & 0.463 & 19,100 & 48,100 & 0.75 & 0.397 \\
\hline AND8 & 2,589 & 26,286 & -- & 0.098 & 1,360 & 17,800 & 3.72 & 0.076 \\
\hline AND9 & 12,948 & 89,693 & -- & 0.144 & 1,790 & 18,800 & 3.15 & 0.095 \\
\hline AND10 & 9 & 260 & -- & 0.034 & 7.37 & 235 & 0.60 & 0.031 \\
\hline AND11 & 6,550 & 44,819 & -- & 0.146 & 6,100 & 18,000 & 0.63 & 0.339 \\
\hline AND-PW & -- & -- & -- & -- & 149,000 & 229,000 & 0.82 & 0.651 \\
\hline
\end{tabular}

Table B-3. Summary of water-quality data for the Fuller study site, Williams County, North Dakota.

[Summarized from table 1-3 (Preston and others, 2012). $\mathrm{Na}^{+} / \mathrm{Cl}^{-}$molar ratio is the quotient of the $\mathrm{Na}^{+}$and $\mathrm{Cl}^{-}$concentrations converted to molar equivalents. Contamination index is calculated by dividing $\mathrm{Cl}^{-}$concentration $(\mathrm{mg} / \mathrm{L})$ by specific conductance value $(\mu \mathrm{S} / \mathrm{cm})$. $\mathrm{Cl}^{-}$, chloride; $\mathrm{mg} / \mathrm{L}$, milligrams per liter; $\mu \mathrm{S} / \mathrm{cm}$, microsiemens per centimeter at 25 degrees Celsius; $\mathrm{Na}^{+}$, sodium]

\begin{tabular}{|c|c|c|c|c|}
\hline \multirow[b]{2}{*}{$\begin{array}{c}\text { Site } \\
\text { name }\end{array}$} & \multicolumn{4}{|c|}{2010} \\
\hline & $\begin{array}{c}\mathrm{Cl}^{-} \\
\mathrm{mg} / \mathrm{L}\end{array}$ & $\begin{array}{c}\text { Specific } \\
\text { conductance, } \\
\mu S / \mathrm{cm}\end{array}$ & $\begin{array}{c}\mathrm{Na}^{+} / \mathrm{Cl}^{-} \\
\text {molar ratio }\end{array}$ & $\begin{array}{c}\text { Contmination } \\
\text { index }\end{array}$ \\
\hline FULL-A & 25.3 & 683 & 1.46 & 0.037 \\
\hline FULL-B & 181 & 3,780 & 2.16 & 0.048 \\
\hline FULL-MW1 & 350 & 24,100 & 15.82 & 0.015 \\
\hline FULL-MW2 & 154 & 3,500 & 1.85 & 0.044 \\
\hline FULL-PWB1 & 199,000 & 251,000 & 0.64 & 0.793 \\
\hline FULL-PWB2 & 198,000 & 241,000 & 0.70 & 0.822 \\
\hline FULL-PWR & 109,000 & 188,000 & 0.65 & 0.580 \\
\hline
\end{tabular}




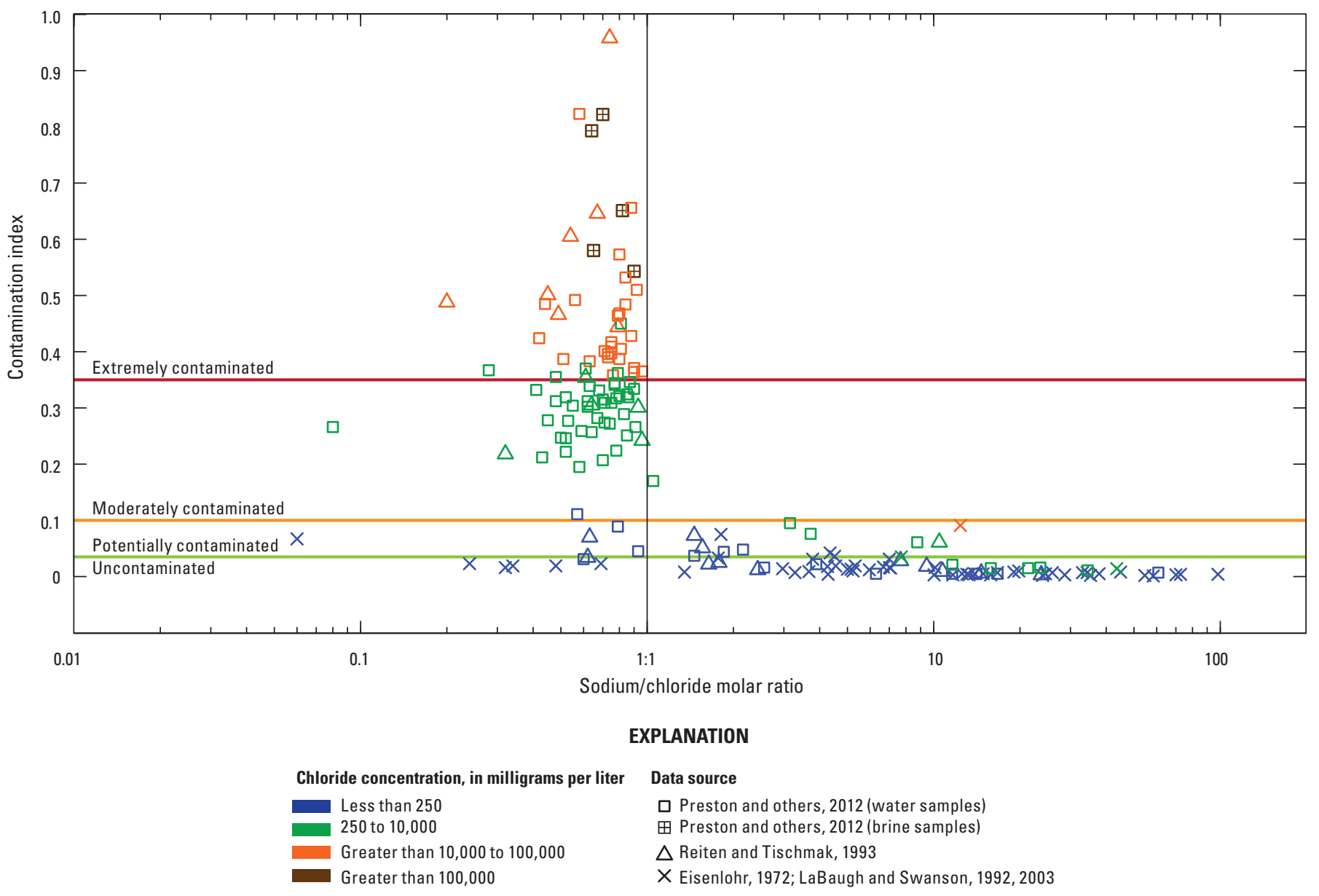

Figure B-2. Sodium/chloride molar ratio compared to contamination index for 96 water-quality samples and 5 brine samples.

value of water from 264T were $12.3 \mathrm{mg} / \mathrm{L}$ and 0.016 in 1989. By 2009, the $\mathrm{Cl}^{-}$concentration and $\mathrm{CI}$ value of water from this well were $1,030 \mathrm{mg} / \mathrm{L}$ and 0.222 , indicating that brine had migrated further along the groundwater-flow path to this well during the 20-year time period.

Surface water and shallow groundwater contaminated by brine in 1989 were still contaminated by brine in 2009 (fig B-3, table B-1). The CI values for water samples collected in 1989 (except for 126C and 264T) were between 0.089 and 0.532 and generally decreased with distance downgradient from active and abandoned oilfield sites. The CI values for water samples from West Goose Lake were greater than 0.035 in $1989(0.107)$ and $2009(0.061)$, indicating that West Goose Lake likely has been contaminated for at least two decades. As indicated by the CI values, only two sites sampled in 1989-monitoring wells $126 \mathrm{C}$ and $264 \mathrm{~T}$, had water that was not contaminated with brine. The CI values for water samples collected in 2009 were between 0.022 and 0.409 , indicating that water from all sampled sites except BGWL was contaminated. Between 1989 and 2009, the CI increased in nine of the sampled sites. Although CI values decreased in 18 sites, the CI values were still elevated, indicating that the brine contamination has persisted in the environment during a two-decade period. However, much of the contamination is likely from leachates generated from reserve pits located at each oil well site and at the tank battery that collects the produced fluids (Reiten and Tischmak, 1993). The oil wells and tank battery were installed in the mid- to late-1960s; therefore, contamination has likely persisted in this environment for as many as four to five decades.

Statistically, there is a significant difference in the $\mathrm{Cl}^{-}$ concentrations, specific conductance, and CI values of water sampled from locations contaminated by brine in 1989 and 2009. A Kolmogorov-Smirnov normality test determined the changes in these parameters were not normally distributed, requiring a nonparametric analysis. The difference in median $\mathrm{Cl}^{-}$concentrations, specific conductance, and $\mathrm{CI}$ values between 1989 and 2009 is nonzero (respective two-sided p-values $=0.006,0.038$, and 0.032 from a Wilcoxon signed rank test with $\mathrm{V}$ stats of 39,56 , and 54). The respective estimated reduction in median $\mathrm{Cl}^{-}$concentration, specific conductance, and CI value are $-4,850 \mathrm{mg} / \mathrm{L},-8,513.5 \mu \mathrm{S} / \mathrm{cm}$, and -0.047 , with 95 percent confidence intervals of $-8,885--888$ $\mathrm{mg} / \mathrm{L},-16,906.5--595.1 \mu \mathrm{S} / \mathrm{cm}$, and $-0.087--0.002$, indicating that the magnitude of brine contamination has slightly decreased during the two-decade period. 

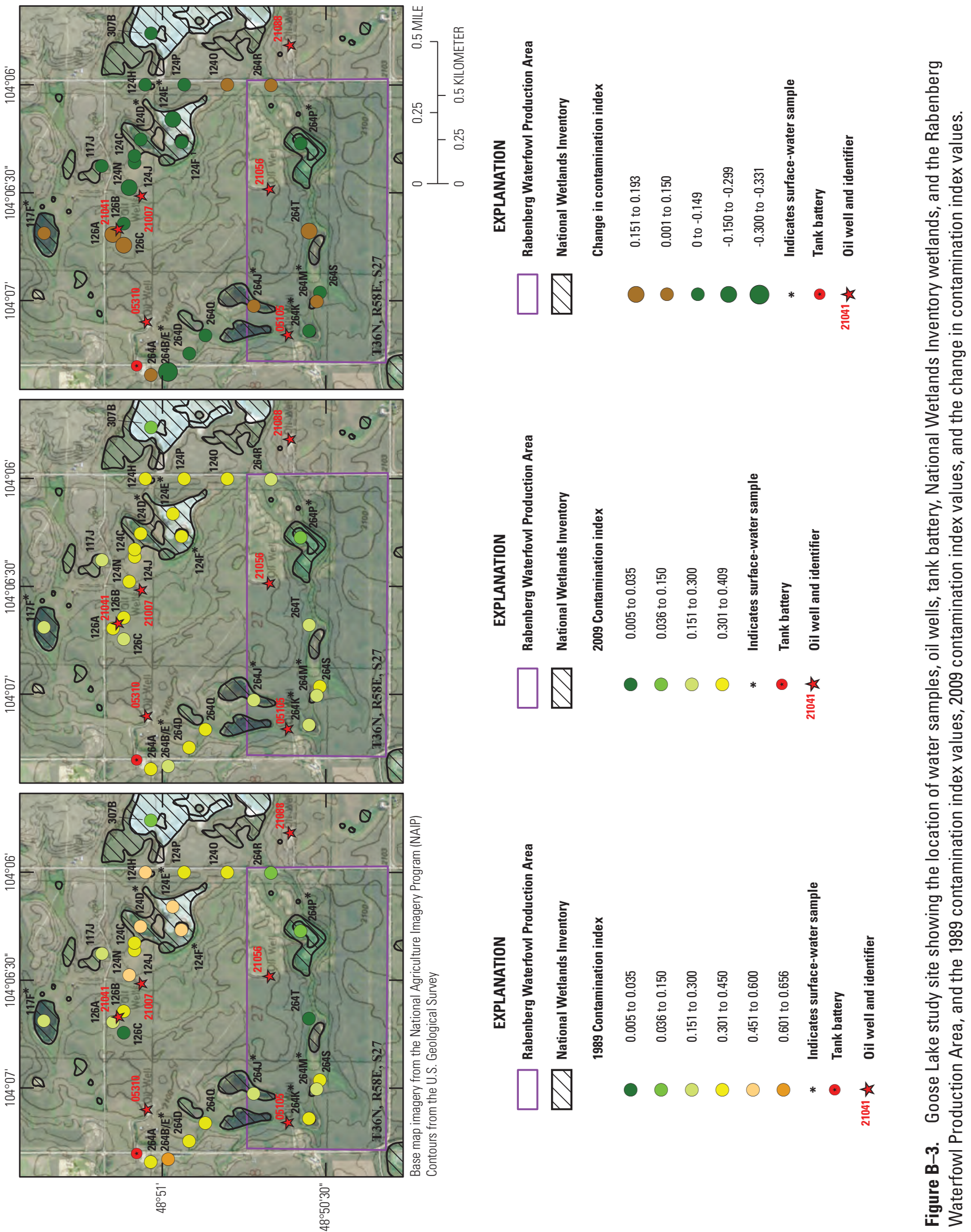
The likely source of brine to surface water and shallow groundwater in the Goose Lake study site is produced waters from the Ratcliffe Formation, as indicated by Sr isotope analyses of 14 water samples from an oil/brine separation tank, surface-water bodies, and shallow monitoring wells (Preston and others, 2012, table B-1). An evaporation-mixing model was developed to interpret the $\mathrm{Sr}$ isotope relations of surface water and shallow groundwater at the Goose Lake study site (Peterman and others, 2012). The model is shown on figure $\mathrm{B}-4$ with ${ }^{87} \mathrm{Sr} /{ }^{86} \mathrm{Sr}$ ratios plotted as a function of Sr concentration on a $\log$ axis. In surface water and shallow groundwater, these parameters can be modified by evaporation (indicated by increases in solute concentrations, but no change in ${ }^{87} \mathrm{Sr} /{ }^{86} \mathrm{Sr}$ values) and the mixing of end members, which can change solute concentrations and ${ }^{87} \mathrm{Sr} r{ }^{86} \mathrm{Sr}$. The shaded area on figure B-4 is the mixing field at the Goose Lake study site as defined by samples of surface water, shallow groundwater, and brine. The horizontal line near the top of the graph depicts the effects of evaporation, increasing $\mathrm{Sr}$ concentration while maintaining the ${ }^{87} \mathrm{Sr} r{ }^{86} \mathrm{Sr}$ values. In the evaporation-mixing model, this line is assumed to be the loci of least contaminated samples. The curved lines are mixing lines calculated from the Goose Lake brine sample (PW1, produced with oil from the Ratcliff Formation), through the samples with largest and smallest Sr concentrations, to intersect the evaporation line at the top of the graph. The area within these lines contains all of the Goose Lake samples analyzed and is labeled "Goose Lake Mixing Field." As discussed by Peterman and others (2012), the process of moving a sample composition from the upper part of the graph towards the brine composition may involve evaporation, brine contamination, and dilution with freshwater, perhaps repeated multiple times. The net effect of these processes is the migration of compositions towards the brine as reflected by the position of the samples on the graph and by the CI values. Using the evaporation-mixing model from the Goose Lake study site as the basis for comparison, the $\mathrm{Sr}$ isotope and concentrations relations for the Anderson and Fuller sites are discussed below.

Contaminated shallow groundwater has migrated at least 600 and $800 \mathrm{~m}$ along two separate groundwater-flow paths in the Goose Lake study site, and possibly as far as $1,600 \mathrm{~m}$. There are two main groundwater-flow paths in the Goose Lake study site; one in the northern part and one in the southern part. In the northern part of the study area, groundwater flows generally eastward from wetland $117 \mathrm{~F}$ and well $126 \mathrm{C}$ through monitoring wells $124 \mathrm{H}, 124 \mathrm{P}$, and $124 \mathrm{O}$. In the southern part of the study area, groundwater flows southward from the tank battery near groundwater well 264A, then eastward near wetland $264 \mathrm{~K}$ though monitoring well 264R. Both of these groundwater-flow paths likely discharge into West Goose Lake. West Goose Lake was moderately contaminated in 1989 and potentially contaminated in 2009, with respective $\mathrm{Cl}^{-}$concentrations of 4,480 and $4,050 \mathrm{mg} / \mathrm{L}$ and CI values of 0.107 and 0.061 . The contamination in West Goose Lake is likely from the brine source(s) within the northern flow path, the brine source(s) within the southern flow path, or a combination from all sources. However, in 1989 and 2009, the $\mathrm{Cl}^{-}$concentrations in the furthest downgradient wells in the northern flow paths $-124 \mathrm{H}(36,500$ and $19,500 \mathrm{mg} / \mathrm{L}$, respectively), $124 \mathrm{P}(16,300$ and $4,370 \mathrm{mg} / \mathrm{L}$, respectively), and $124 \mathrm{O}(7,840$ and $17,200 \mathrm{mg} / \mathrm{L}$, respectively) -were much greater than the furthest downgradient well in the southern flow path - 264R (195 and $732 \mathrm{mg} / \mathrm{L}$, respectively). Therefore, if volume of groundwater discharge to West Goose Lake is similar from the northern and southern flow paths, then the more saline northern flow path likely has the greater effect to West Goose Lake.

Potential sources of brine along the northern groundwaterflow path include oil wells 21041 (126) and 21007 (124). In 1989, 2006, and 2009, all surface water and groundwater samples (except 126C in 1989) had CI values equal to or greater than 0.170 and $\mathrm{Cl}^{-}$concentrations equal to or greater than $450 \mathrm{mg} / \mathrm{L}$ (table $\mathrm{B}-1$ ), indicating moderate to extreme brine contamination throughout the entire flow path (fig. B-5). Therefore, it is unclear if the source of brine in West Goose Lake (307B) is oil well 21007 (124), oil well 21041 (126), or both. However, the approximate distances that groundwater would have to migrate along the northern flow path to reach the western shore of West Goose Lake is $800 \mathrm{~m}$ from oil well 21007 (124) and 1,100 m from oil well 21041 (126).

Potential sources of brine along the southern groundwater flow-path include a tank battery and oil wells 05105 (127) and 21056 (128). Respective CI values and $\mathrm{Cl}^{-}$concentrations in all surface water and groundwater samples (except $264 \mathrm{~T}$ in 1989 and BGWL in 2009) ranged from 0.089 to 0.656 and 80 to $66,900 \mathrm{mg} / \mathrm{L}$ in $1989,0.207$ to 0.656 and 1,172 to 47,000 $\mathrm{mg} / \mathrm{L}$ in 2005 , and 0.111 to 0.409 and 98 to $37,500 \mathrm{mg} / \mathrm{L}$ in 2009 (table B-1), indicating potential to extreme brine contamination throughout most of this flow path (fig. B-6). The presence of oil wells 05105 (127) and 21056 (128) make identifying the source(s) and distance of contaminant migration throughout this flow path difficult, especially between the tank battery and 264T. Monitoring well 264T was not contaminated in 1989 while wetland 264P, monitoring well 264R, and West Goose Lake (307B) were contaminated, indicating that the likely brine source downgradient from 264T in 1989 was from oil well 21056 (128). The distance along the southern flow path from oil well 21056 (128) through $264 \mathrm{P}$ to $264 \mathrm{R}$ is approximately $700 \mathrm{~m}$, and approximately $1,000 \mathrm{~m}$ to the western shore of West Goose Lake. However, 264T had become moderately contaminated in 2009 (CI value of 0.222 ), and the brine source(s) between oil well 05105 (127) to 264T could be from the tank battery, this oil well, or both. Separating out these sources is further complicated as the relative trends in CI values up- and downgradient from oil well 05105 (127) change through time. In 1989 and 2005, the CI value increases between upgradient $264 \mathrm{~J}$ and downgradient $264 \mathrm{~K}$, but the $\mathrm{CI}$ value decreases between these two sites in 2009 . Therefore, while the brine source at $264 \mathrm{~T}$ is unclear, the respective distances along the southern flow path to 264T from oil well 05105 (127) and the tank battery are approximately 600 and 1,600 m. Lastly, it should be noted that the contaminated groundwater has likely migrated beyond 264T, so these distances represent a minimum transport distance. 


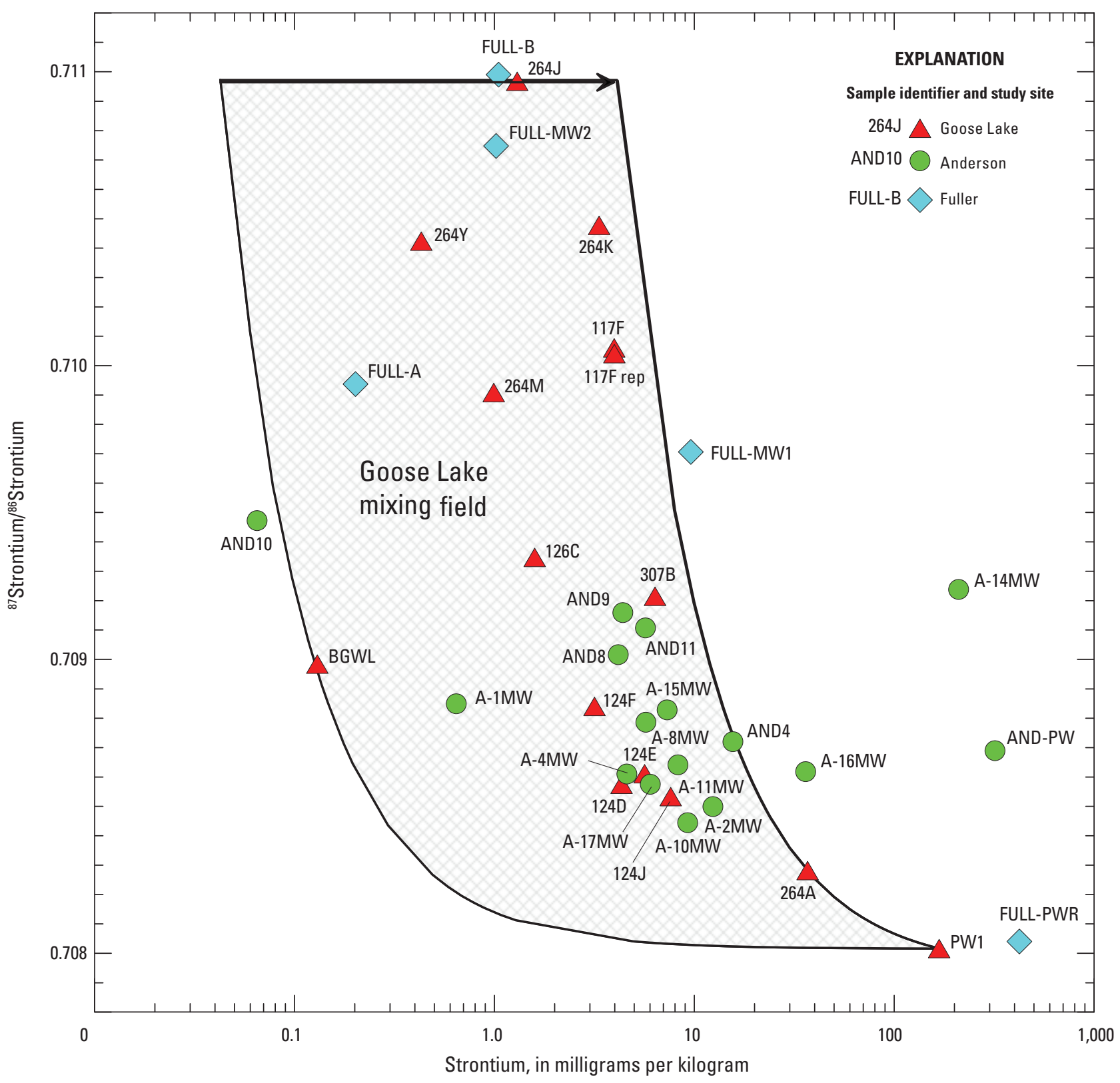

Figure B-4. Strontium $(\mathrm{Sr})$ concentration compared to ${ }^{87} \mathrm{Sr} /{ }^{86} \mathrm{Sr}$ values for water samples from all three study sites: Goose Lake, Anderson, and Fuller.

\section{Anderson Study Site}

Water was collected during 2005 and 2010 from a monitoring well (A-1MW) within the study site and upgradient from potential brine sources to represent background water quality and to compare with water samples that were collected from contaminated wetlands and wells. Water was collected during 2010 from an oil/brine separation tank (AND- PW) located at the tank battery within the WPA that receives oil and brine from nearby oil wells and was assumed to represent brines from the Ratcliffe Formation. However, based on the Sr isotope data and the producing formations of nearby oil wells, the brine sampled in AND- PW likely represents, in part, the Nisku or Red River Formations.

Uncontaminated water (CI less than 0.035) was collected during 2005 and 2010 from three monitoring wells (A-10MW, $\mathrm{A}-11 \mathrm{MW}$, and $\mathrm{A}-15 \mathrm{MW}$ ) in addition to background monitoring well A-1MW (table B-2). $\mathrm{Cl}^{-}$concentrations did not exceed $360 \mathrm{mg} / \mathrm{L}$ in these samples. Water from A-1MW (background site) contained concentrations of major ions and trace elements that were much lower than the concentrations in any other samples. During 2005 and 2010, water from $\mathrm{A}-10 \mathrm{MW}$ and $\mathrm{A}-11 \mathrm{MW}$ contained relatively higher concentrations of most major ions and trace elements except for $\mathrm{Cl}^{-}$, which, along with specific conductance, is used as the 


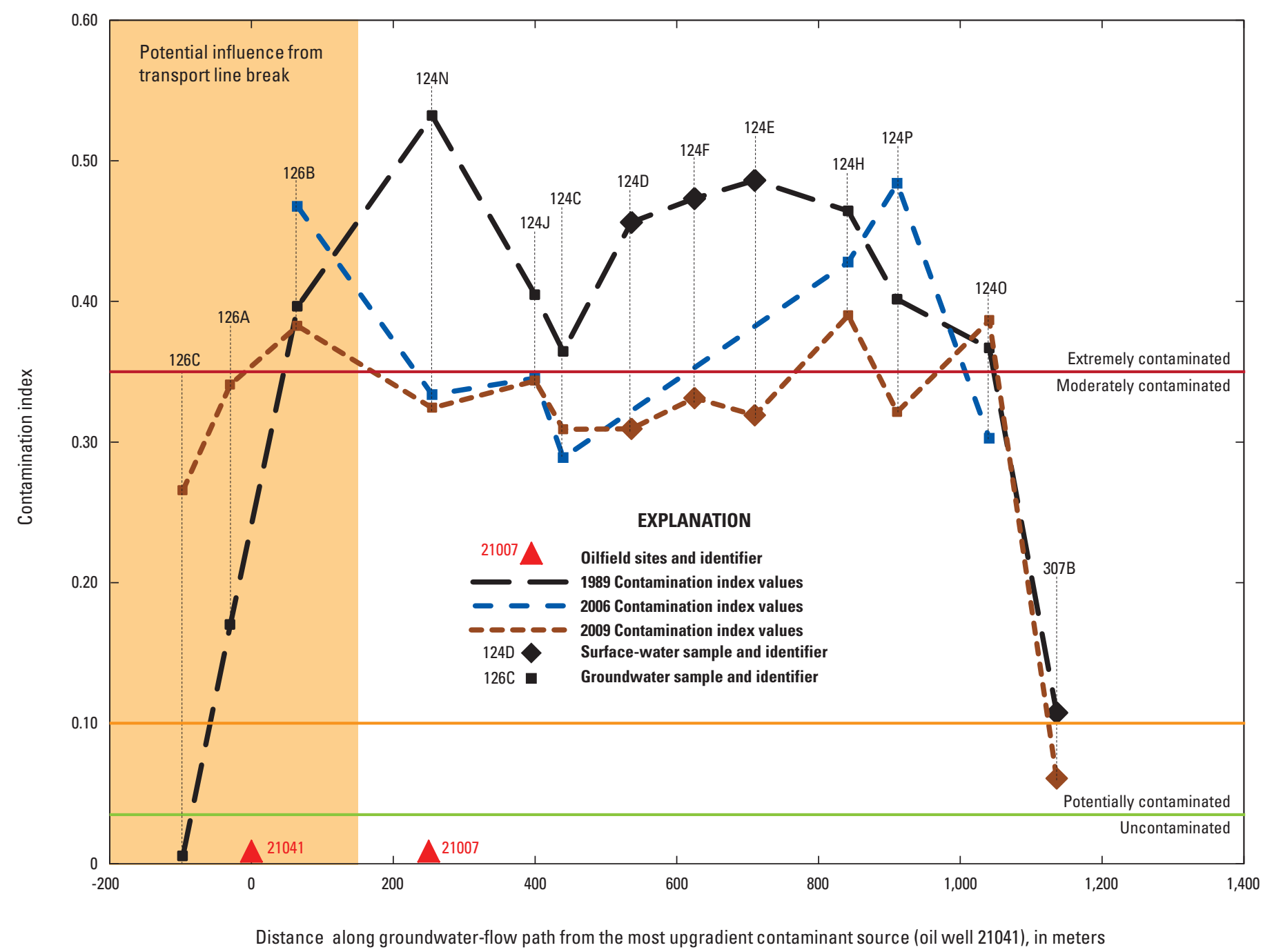

Figure B-5. Contamination index values of surface water and groundwater samples from 1989, 2006, and 2009 plotted by distance from the most upgradient brine source (oil well 21041) in the northern groundwater-flow path at the Goose Lake study site.

indicator for brine contamination. These two wells are located along a potential flow path. Analyses of water from A-11MW during 2010 indicated that the $\mathrm{Cl}^{-}$concentration and $\mathrm{CI}$ value had increased from 2005; however, the CI value was still below 0.035 . Monitoring well $\mathrm{A}-15 \mathrm{MW}$ is adjacent to an oil well and reserve pit, yet the CI values in 2005 and 2010 were below 0.035 .

All surface-water and shallow groundwater sites with CI values indicating brine contamination in 2004-5 still had CI values greater than 0.035 in 2010 (fig. B-7, table B-2). The CI values for water samples collected in 2004-5 were between 0.005 and 0.823 and generally decreased with distance downgradient from potential sources of brine. The CI values for water samples collected in 2010 were between 0.005 and 0.492 and, compared to 2004-5, had decreased at 11 sites and increased or stayed the same at 4 sites, indicating that the brine has persisted in the environment during the 5-6-year period. Similar to the Goose Lake site, much of the contamination is likely from leachates generated from the reserve pits located at each oil well site and the tank battery that collects the produced fluids (Reiten and Tischmak, 1993). The oil wells and tank battery within the Anderson WPA were installed in the mid- to late-1960s, indicating that contamination likely has persisted in this environment for as many as four to five decades.

Statistically, there was no significant difference in the $\mathrm{Cl}^{-}$concentrations, specific conductance, or $\mathrm{CI}$ values of water sampled from locations contaminated by brine in 2004-5 and 2010. A Kolmogorov-Smirnov normality test determined that these parameters were not normally distributed, requiring nonparametric analyses. The difference in median $\mathrm{Cl}^{-}$concentrations, specific conductance, or CI values between 2004-5 and 2010 is nonzero (respective two-sided p-values equal $0.432,0.160$, and 0.232 from a Wilcoxon signed rank test with $\mathrm{V}$ statistics of 36,42 , and 15), indicating that the magnitude of brine contamination has not changed significantly over the 5-6-year period. 


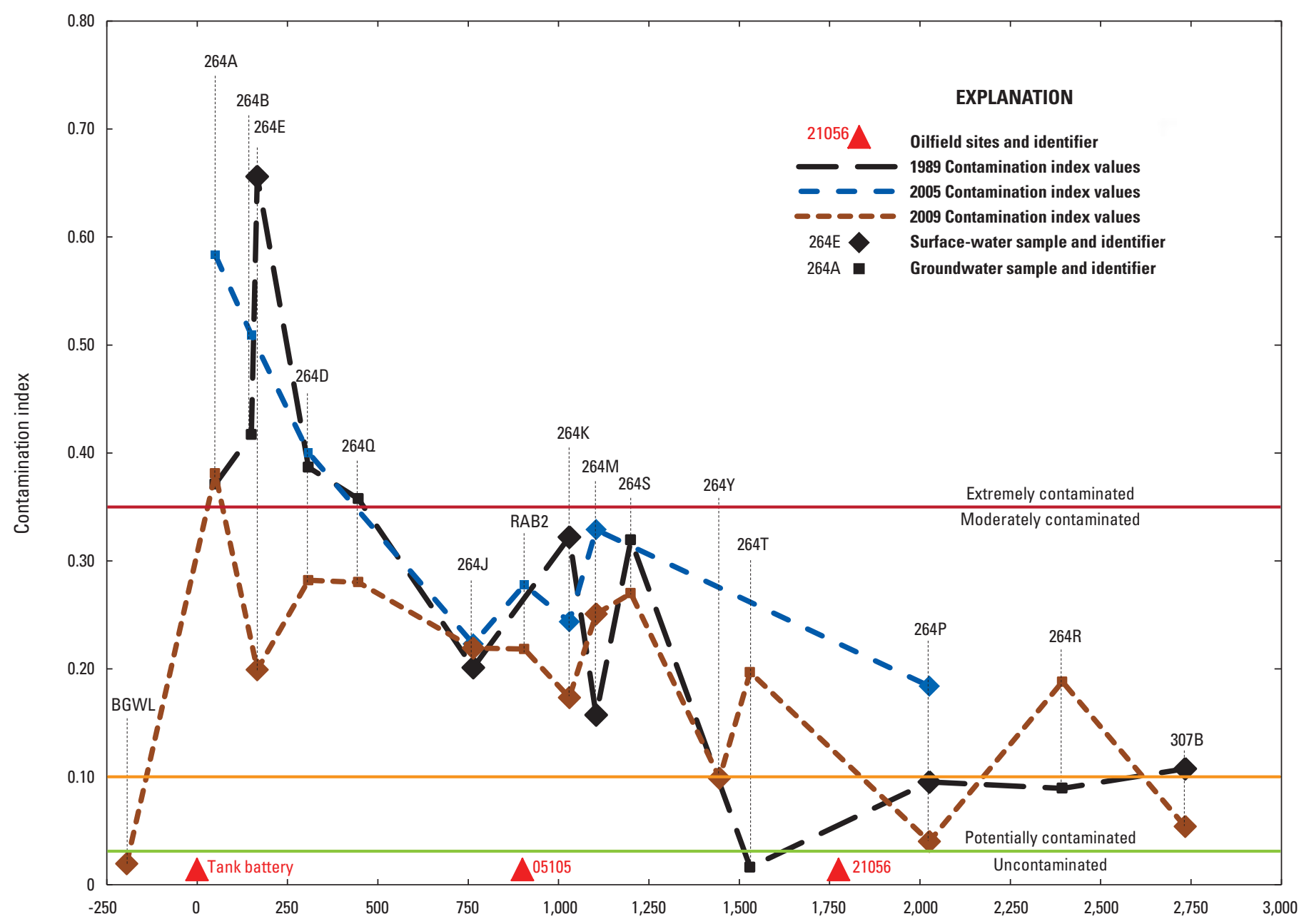

Distance along groundwater-flow path from the most upgradient contaminant source (tank battery), in meters

Figure B-6. Contamination index values of surface water and groundwater samples from 1989, 2005, and 2009 plotted by distance from the most upgradient brine source (tank battery) in the southern groundwater-flow path at the Goose Lake study site.

The likely source of much of the brine to surface water and shallow groundwater in the Anderson study site is produced waters from the Ratcliffe Formation, as indicated by Sr isotope analyses of 16 water samples from surface-water bodies, shallow monitoring wells, and an oil/brine separation tank (Preston and others, 2012, table B-2). The Sr concentration and ${ }^{87} \mathrm{Sr} /{ }^{86} \mathrm{Sr}$ values for most of Anderson samples plot within or very close to the ${ }^{87} \mathrm{Sr} /{ }^{86} \mathrm{Sr}$ values for the Goose Lake model (fig. B-4). Wetland sample AND10 has the lowest concentration of $\mathrm{Sr}(0.065 \mathrm{mg} / \mathrm{L})$ and plots just to the left of the other Anderson samples. The sample from monitoring well A-16MW has the third highest concentration of $\mathrm{Sr}$ (36 $\mathrm{mg} / \mathrm{L}$ ) and, therefore, plots just to the right of most Anderson samples in figure B-4. Greater departure from the Goose Lake model is shown by monitoring well A-14MW with the highest $\mathrm{Sr}$ concentration $(210 \mathrm{mg} / \mathrm{L})$ and a ${ }^{87} \mathrm{Sr} /{ }^{86} \mathrm{Sr}$ value of 0.70924. However, the oil well adjacent to A-14MW (21351) never produced; therefore, the fluids in the reserve pit were likely derived predominantly during drilling through younger stratigraphic units, which may explain the discordance with other Anderson samples. The produced water sample (AND-PW) is similar in Sr concentration to A-14MW but has a ${ }^{87} \mathrm{Sr} /{ }^{86} \mathrm{Sr}$ value $(0.70869)$ significantly larger than that of the brine sample from Goose Lake (PW1=0.70802). The ${ }^{87} \mathrm{Sr} /{ }^{86} \mathrm{Sr}$ value of AND-PW is larger than some of the Anderson surface-water and shallow groundwater samples; thus, AND-PW cannot have been the end member that affected samples with smaller ${ }^{87} \mathrm{Sr} /{ }^{86} \mathrm{Sr}$ values. Rather, the locations of Anderson samples on figure B-4 are consistent with mixing with a produced water component similar to the Goose Lake sample (PW1). The brine sample AND-PW was collected from a tank battery, which represents an aggregate sample of brines produced from numerous wells. It is likely this sample is a mixture of brines from multiple stratigraphic units, with some of these brines having a greater ${ }^{87} \mathrm{Sr} /{ }^{86} \mathrm{Sr}$ value. Although the oil wells that supply oil and brine to the tank battery are 

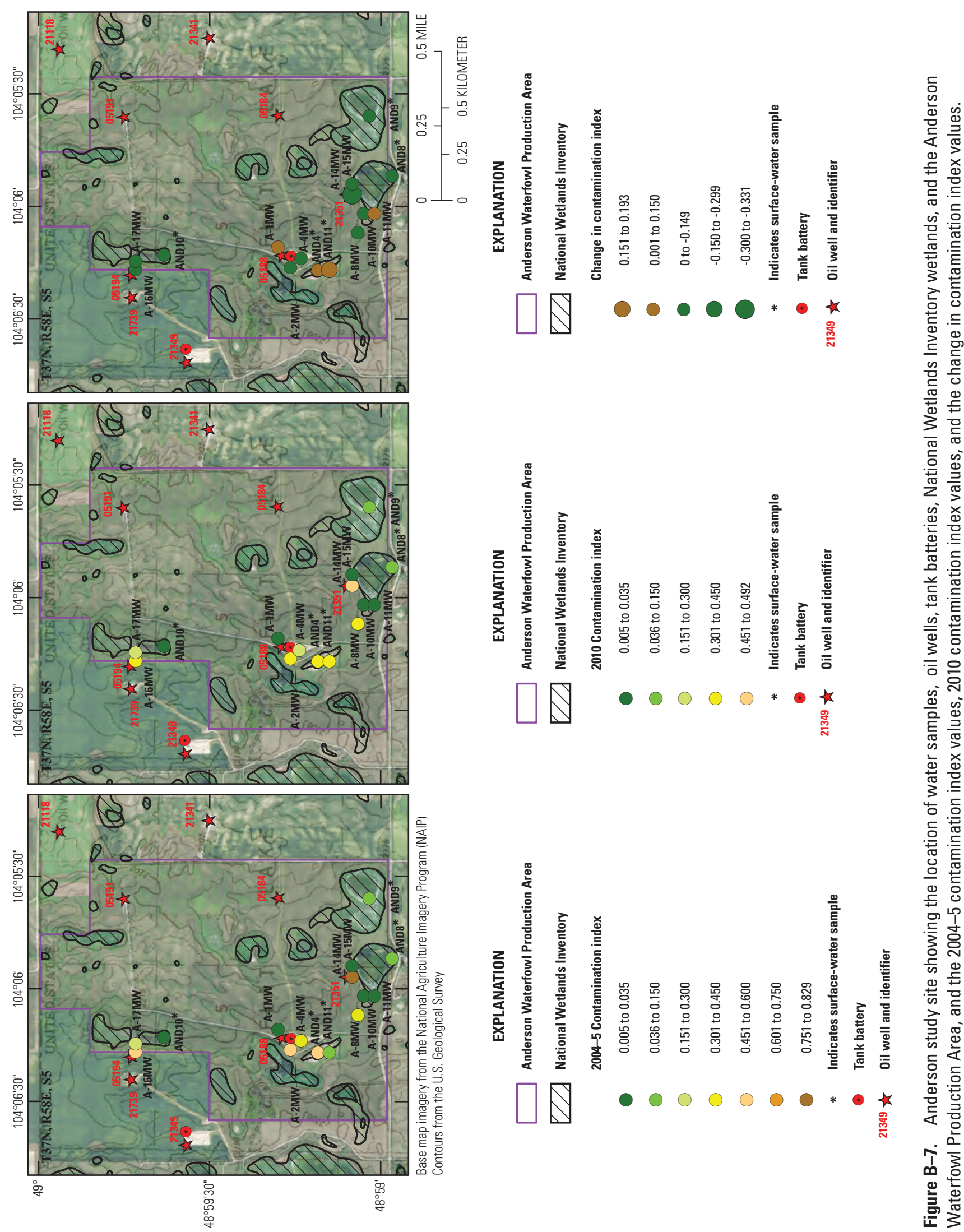
unknown, the nearest producing oil well, 21712 (not shown on fig. B-7, approximately $0.5 \mathrm{~km}$ west of the WPA) produces from the Nisku and Red River Formations, not the Ratcliffe Formation, which was the producing unit for the oil wells in the Anderson WPA. Qing and others (2001) reported an average ${ }^{87} \mathrm{Sr} r{ }^{86} \mathrm{Sr}$ value of 0.7086 for the matrix dolomite in the Red River Formation, very similar to the ${ }^{87} \mathrm{Sr} /{ }^{86} \mathrm{Sr}$ value of AND-PW (0.70869).

Contaminated groundwater has migrated at least 400 $\mathrm{m}$ in the Anderson study site and possibly as far as 1,200 $\mathrm{m}$ (fig. B-8). These are the greatest distances between the potential source (oil well or tank battery) and the most downgradient contaminated monitoring well or wetland. Groundwater generally flows southward from A-1MW, then eastward near A-8MW towards AND8 and AND9; the likely discharge points of this groundwater-flow path. Monitoring well A-8MW is approximately $400 \mathrm{~m}$ from a tank battery and oil well (05188), while wetland AND9 is approximately $1,200 \mathrm{~m}$ from these same facilities. Water from monitoring wells A-10MW and A-11MW was uncontaminated in 2004 and 2010 indicating that contamination from the tank battery or oil well 05188 likely did not reach these wetlands through groundwater flow. However, water samples from wetlands AND8 and AND9 were moderately or potentially contaminated in 2004 and 2010 (AND8 CI value $=0.098$ and 0.076, respectively; AND9 CI value $=0.144$ and 0.095 , respectively) but have lower ${ }^{87} \mathrm{Sr} /{ }^{86} \mathrm{Sr}$ values than $\mathrm{A}-14 \mathrm{MW}$, which is partially completed in the reserve pit of oil well 21351 and located directly above the basin of wetland AND8; thus, the buried reserve pit at oil well 21351 cannot be the sole brine source for wetlands AND8 and AND9. Two other oil wells completed in the Ratcliffe Formation (21361 and 05174 and not shown on fig. B-7) are located approximately $0.3 \mathrm{~km}$ to the south of wetlands AND8 and AND9 and may be the source of brine in these wetlands. Therefore, while the brine source in wetland AND9 is unclear, if the source is the tank battery or oil well 05188 , it would represent a migration distance of approximately $1,200 \mathrm{~m}$.

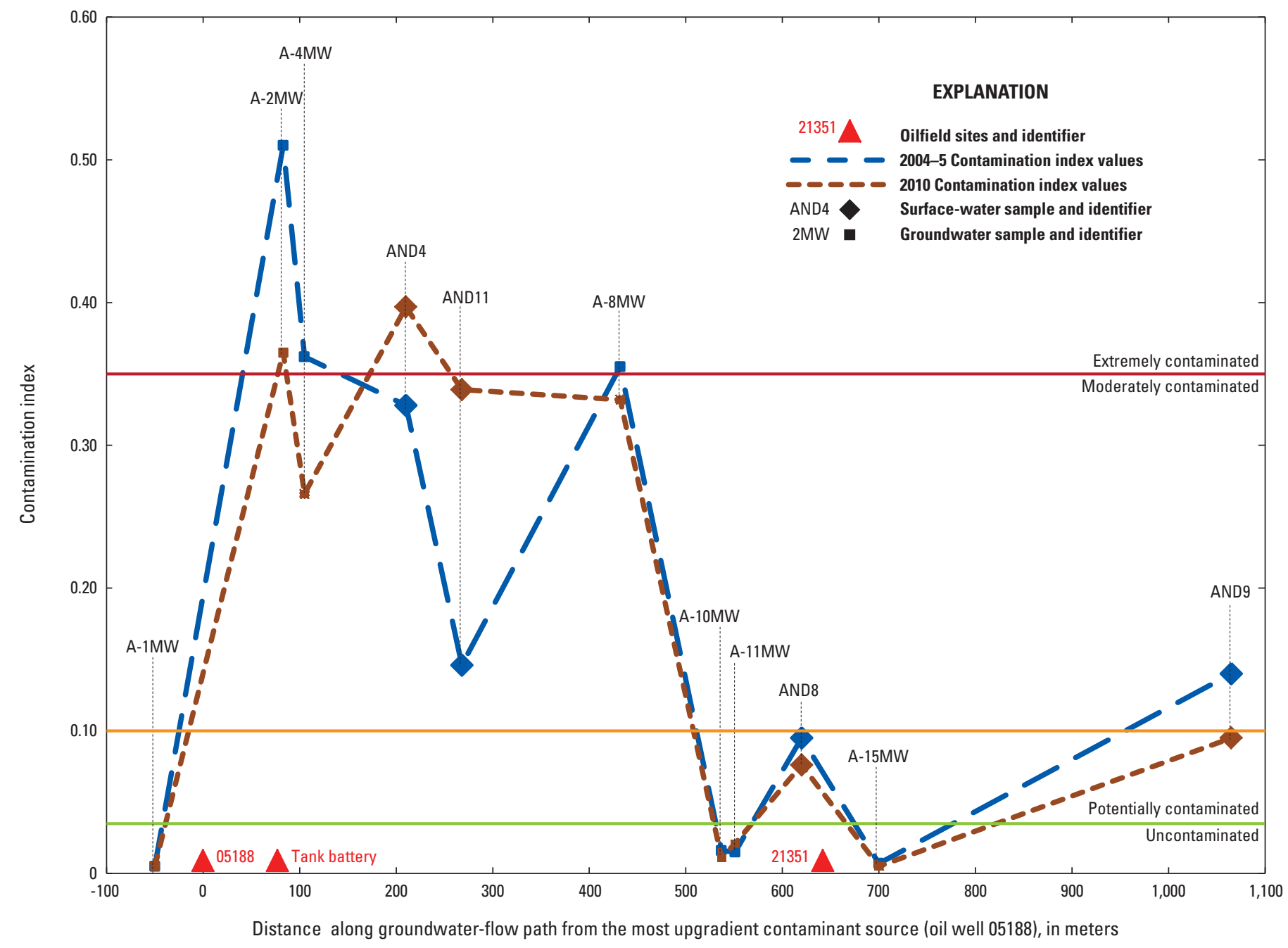

Figure B-8. Contamination index values of surface water and groundwater samples from 2004-5 and 2010 plotted by distance from the most upgradient brine source (oil well 05188) in the groundwater-flow path at the Anderson study site. 


\section{Fuller Study Site}

Water was collected from one monitoring well (FULLMW1) during 2010 that was thought to be unaffected by oil and gas activities but had unusual major ion chemistry. Although this well had the lowest CI value (0.015), the $\mathrm{Cl}^{-}$ concentration at this well $(350 \mathrm{mg} / \mathrm{L})$ was higher than concentrations in water from the three other surface-water and shallow groundwater sites that were sampled (range 25-181 $\mathrm{mg} / \mathrm{L}$; table B-3). However, water from FULL-MW1 contains higher concentrations of other major ions such as $\mathrm{Na}^{+}$, magnesium, and $\mathrm{SO}_{4}^{2-}$, indicating that this water type is unique from the other sample sites.

Based on the CI values, three of the four surface-water and shallow groundwater samples from the Fuller study site were potentially contaminated by brine in 2010 (table B-3, fig. B-9). The CI values for the three other water samples besides FULL-MW1 were between 0.037 and 0.048 and were highest in the wetland (FULL-B) below the reservoir (where sample FULL-A was collected).

The distance of contaminated groundwater migration is not possible to determine at the Fuller study site because of the limited number of sample sites and understanding of groundwater-flow flow paths. Surface-water sample site FULL-A is upgradient from potential brine sources within the Fuller study site, so a potential source to this site is likely located off the study site and upgradient from the reservoir.

Sr isotopes and concentrations of samples from the Fuller study site (Preston and others, 2012, table B-3) are consistent with the Goose Lake evaporation-mixing model (fig. B-4) and indicate possible brine contamination despite the relatively low CI values. Sample FULL-B plots close to Goose Lake sample 264J, which was used to show an evaporation line at the top of the field. The sample from monitoring well FULLMW1 $(9.6 \mathrm{mg} / \mathrm{L} \mathrm{Sr})$ plots slightly to the right of the Goose Lake field. The Fuller produced waters sample (FULL-PWR) is isotopically similar to PW1, the brine from Goose Lake, but the $\mathrm{Sr}$ concentration at $423 \mathrm{mg} / \mathrm{L}$ is larger. If FULL-PWR was used as an end member for a Fuller mixing plot, FULL-MW1 would plot within the field. The isotopic similarity of PW1 and FULL-PWR lends credence to the interpretation that the brine sample from Anderson (AND-PW) is not representative of the Ratcliffe Formation based on the elevated ${ }^{87} \mathrm{Sr} /{ }^{86} \mathrm{Sr}$ value.

\section{Geophysical Surveys}

Geophysical results in 2004, 2009, and 2010 compared well to groundwater chemistry results, with elevated apparent conductivity readings (greater than $50 \mathrm{mS} / \mathrm{m}$ ) measured near the majority of monitoring wells with high $\mathrm{Cl}^{-}$concentrations (greater than $250 \mathrm{mg} / \mathrm{L}$ ) and CI values (greater than 0.035). The presence of elevated apparent conductivities associated with brine contamination validates the use of EM surveys to delineate brine plumes. However, it should be noted that apparent conductivity increases with clay content and soil saturation, often resulting in elevated apparent conductivity

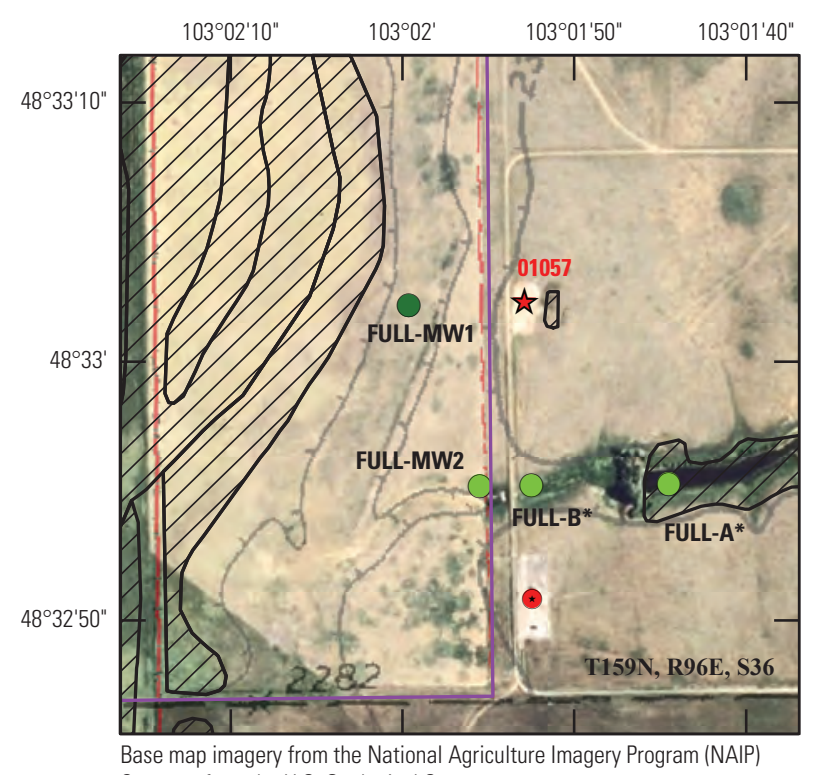

Contours from the U.S. Geological Survey

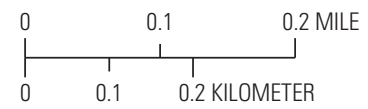

\section{EXPLANATION}

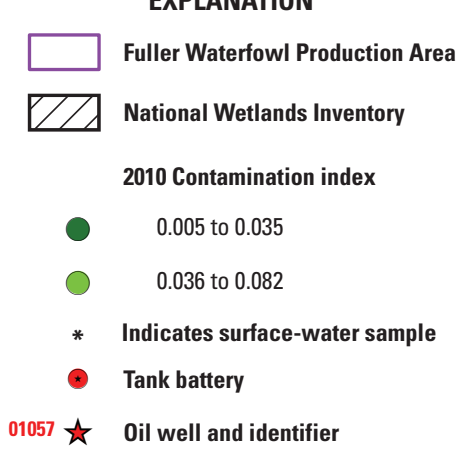

Figure B-9. Fuller study site showing the locations of water samples, oil well 01057, tank battery, National Wetlands Inventory wetlands, the Fuller Waterfowl Production Area boundary, and the contamination index values from 2010.

in and around wetland basins. Additionally, the shallow exploration depth of the EM-31 (roughly $6 \mathrm{~m}$ ) can make it highly susceptible to changes in the depth to the water table that commonly develop in areas of undulating topographic relief (Reiten and Tischmak, 1993). This resulted in elevated conductivities measured only when the water table was within the exploration depth of the EM-31. Finally, it should be noted that the apparent conductivity scales on the figures displaying geophysical data (figs. B-10 through B-18) are equivalent for different geophysical equipment within each study site, but differ between study sites. 


\section{Goose Lake Study Site}

\section{EM-31 Geophysical Surveys}

Several areas of elevated conductivities associated with brine plumes were delineated in the EM- 31 surveys at the Goose Lake study site in 2004 and 2009 (figs. B-10, B-11). A brine plume emanating from the tank battery (264) and migrating southeast down the slough (a shallow, steep-sided depression that seasonally contains flowing or stagnant water) below was suggested from EM-31 surveys in 2004 and 2009. Indeed, the largest EM-31 apparent conductivity values were measured in this slough in both $2004(450 \mathrm{mS} / \mathrm{m})$ and $2009(445 \mathrm{mS} / \mathrm{m})$. The rapid drop to background conductivity values in areas hydraulically upgradient (northwest of the tank battery; fig. B-11) are consistent with initial work by Reiten and Tischmak (1993) documenting the tank battery as the source of brine. Elevated apparent conductivities associated with this plume were evident as far downgradient as surveyed; near oil well 05105 (127) in 2004 and the northern edge of wetland 264J in 2009. The area near oil well 05105
(127) in 2009 likely delineates this brine plume as well and shows an expansion of elevated apparent conductivities to the southeast relative to 2004. However, it should be noted that elevated apparent conductivities were recorded near oil well 05105 (127) in the 2004 surveys and are likely related to the buried reserve pit at this well; therefore, the expansion seen in 2009 may be from the buried reserve pit or contaminated groundwater from the tank battery, or both. The presence of brine as the source of elevated apparent conductivity measurements in 2004 was confirmed by $2005 \mathrm{CI}$ values indicating extremely contaminated groundwater from monitoring wells $264 \mathrm{~A}(0.656), 264 \mathrm{~B}(0.573)$, and 264D (0.450) and moderately contaminated groundwater from RAB2 (0.312). Similarly, CI values in 2009 indicated extremely contaminated groundwater from well 264A (0.409) and moderately contaminated groundwater from wells 264D (0.317), 264Q (0.315), and RAB2 (0.246). Additionally, the downgradient migration or dilution of the brine plume are supported by decreases in the CI values in monitoring wells 264A (-0.247), 264D (-0.133), and RAB2 $(-0.066)$ in the upgradient portion of the brine plume between 2005 and 2009.

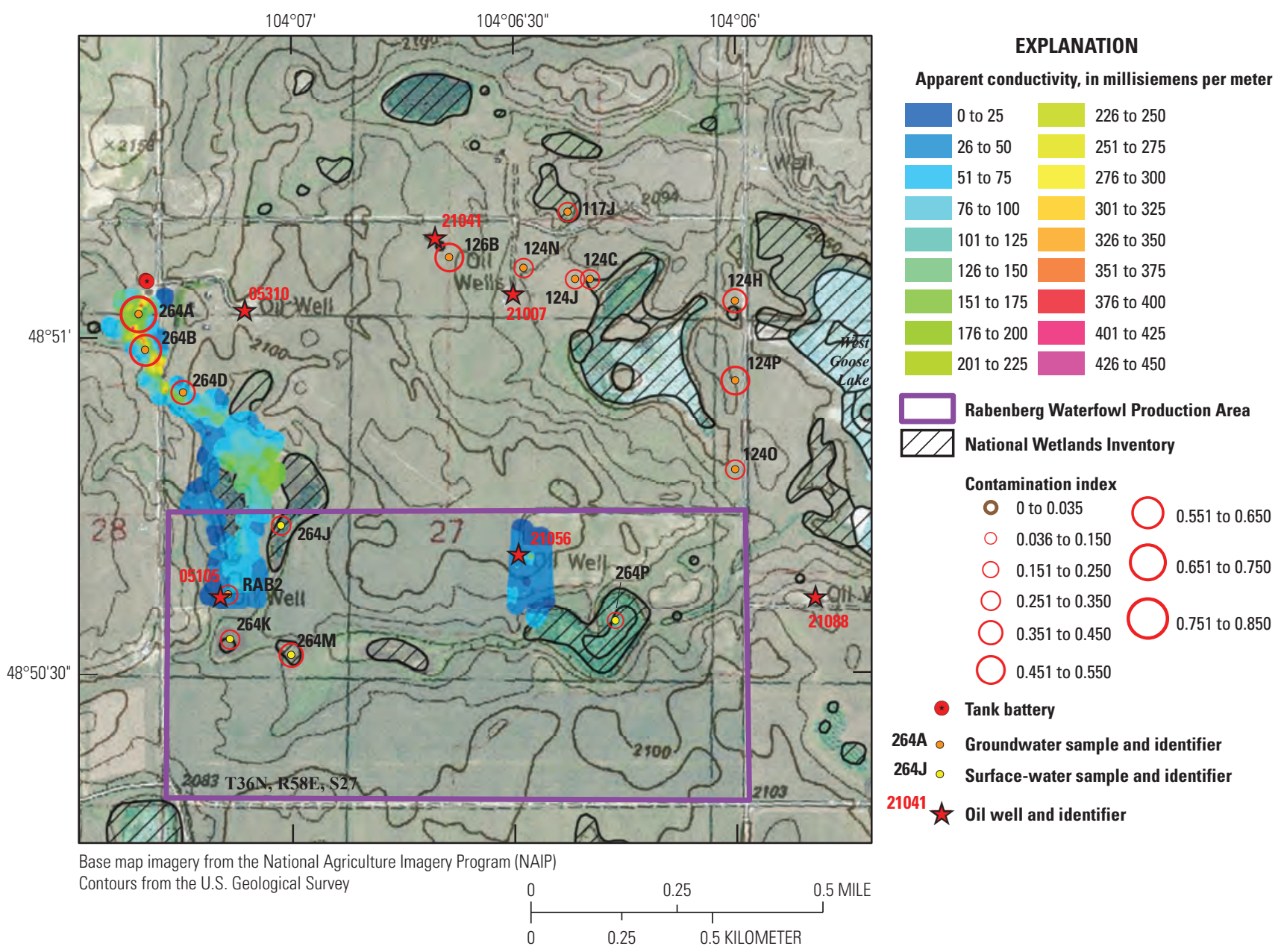

Figure B-10. Goose Lake study site showing the location of water samples, oil wells, tank battery, National Wetlands Inventory wetlands, and the Rabenberg Waterfowl Production Area, as well as the 2005-6 contamination index values and apparent conductivity results from the 2004 EM-31 geophysical surveys. 


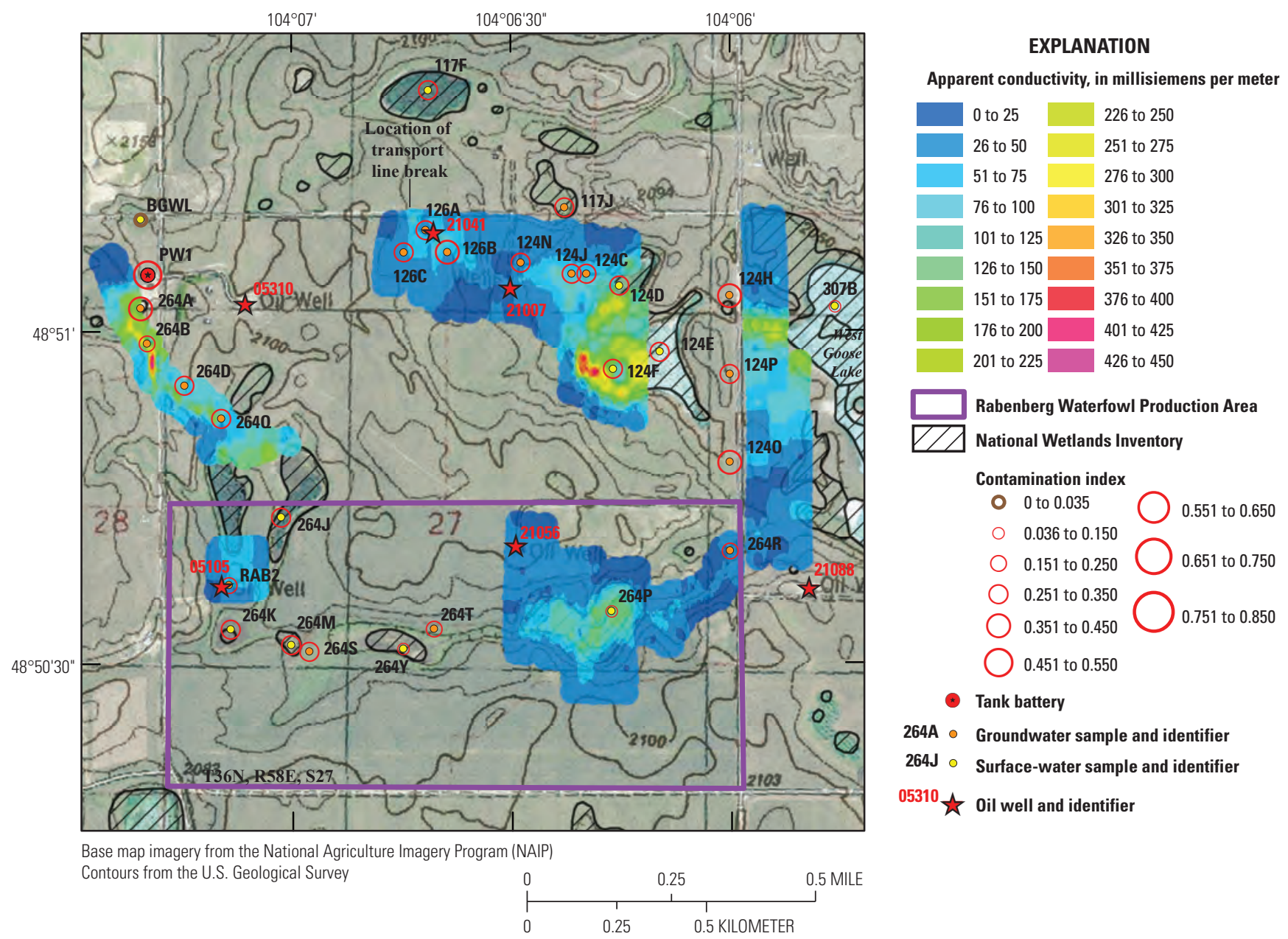

Figure B-11. Goose Lake study site showing the location of water samples, oil wells, tank battery, National Wetlands Inventory wetlands, and the Rabenberg Waterfowl Production Area, as well as the 2009 contamination index values and apparent conductivity results from the 2009 EM-31 geophysical surveys.

Elevated apparent conductivity measurements (maximum of $180 \mathrm{mS} / \mathrm{m}$ ) were measured over a small area east of oil well 21056 (128) in 2004, likely delineating the old reserve pit (fig. B-10). Apparent conductivity measurements near oil well 21056 (128) in 2009 were much lower (maximum of $45 \mathrm{mS} / \mathrm{m}$ ); however, unlike in 2004, the spacing between measurements was grid-based in 2009 with fewer measurement points than 2004, and no measurements were collected over the old reserve pit (fig. B-11). The surveyed area near oil well 21056 (128) was expanded in 2009 to include the basin of wetland 264P and the slough leading to monitoring well 264R. Additional surveys also were performed east of monitoring wells $264 \mathrm{R}, 124 \mathrm{O}, 124 \mathrm{P}$, and $124 \mathrm{H}$ to the western shore of West Goose Lake. The 2009 surveys documented elevated apparent conductivities in and around wetland 264P (maximum of $155 \mathrm{mS} / \mathrm{m}$ ) and in the slough leading to 264R (maximum of $82 \mathrm{mS} / \mathrm{m}$ ). While the groundwater beneath the entire slough is likely moderately contaminated as evidenced by the $2009 \mathrm{CI}$ value at 264R (0.212), the spatially interpolated surface shows only a thin strip of elevated conductivity in the slough. However, this is likely because of the deep water table (approximately $2 \mathrm{~m}$ at 264R in October 2009) and the steep-sided slough. The expansion of elevated apparent conductivities with the loss of topography from the slough near and eastward of 264R supports this conclusion.

The EM-31 surveys measured elevated apparent conductivities adjacent to abandoned oil well 21007 (124) in 2009 and defined a brine plume expanding southeastward (fig. B-11). The maximum apparent conductivities associated with this plume were measured south of wetland sample 124D $(300 \mathrm{mS} / \mathrm{m})$ and west of wetland sample $124 \mathrm{~F}(420 \mathrm{mS} / \mathrm{m})$. Although no groundwater samples were collected in the areas of maximum apparent conductivity, 2009 CI values indicated moderately contaminated groundwater from monitoring wells $124 \mathrm{C}(0.309), 124 \mathrm{~J}(0.344)$, and $124 \mathrm{~N}(0.324)$ in the northern portion of the plume and confirmed the presence of brine. Additionally, the 2009 CI values recorded in the aforementioned wetlands ( 0.309 and 0.331 , respectively), as well as wetland 124E (0.319), also indicated moderate contamination and further support the hypothesis that the maximum elevated 
apparent conductivities are because of brine-contaminated groundwater. Elevated apparent conductivities (maximum of $240 \mathrm{mS} / \mathrm{m}$ ) were also observed in the survey area located between West Goose Lake and monitoring wells 124H, 124O, and $124 \mathrm{P}$ and likely define the downgradient continuation of this brine plume. These three monitoring wells are along the west edge of the survey area and the 2009 CI values from monitoring wells $124 \mathrm{H}(0.390), 124 \mathrm{O}(0.387)$, and 124P (0.321) confirm that the elevated apparent conductivities near West Goose Lake are the result of extremely and moderately contaminated groundwater.

The EM-31 surveys near abandoned oil well 21041 (126) in 2009 documented two areas of elevated apparent conductivities near the well pad and support the conclusion that the increased CI values between 1989 and 2009 in monitoring wells $126 \mathrm{~A}(0.170$ and 0.341 , respectively) and $126 \mathrm{C}(0.005$ and 0.266 , respectively) are because of the transport line break in 2006 (fig. B-11). In 1989, an area of elevated apparent conductivity delineating a brine plume with extremely contaminated groundwater, which likely was emanating from the buried reserve pit, was measured northwest of monitoring well 126B (CI value of 0.396), with apparent conductivities returning to background levels near the site access road (Reiten and Tischmak, 1993, p. B-34). Elevated apparent conductivity measurements in 2009 also defined the extremely contaminated groundwater plume associated with the buried reserve pit northwest of 126B (CI value of 0.383 ), and an additional area north of $126 \mathrm{C}$ at the approximate location of the transport line break. This new area of elevated apparent conductivity measurements defines a new, moderately contaminated, brine plume that emanates from the transport line break and has migrated south to monitoring wells $126 \mathrm{~A}$ and $126 \mathrm{C}$. These results illustrate the continued potential of brine contamination to aquatic resources in the PPR from routine oilfield operations.

\section{EM-34 Geophysical Surveys}

The relative trends in the EM-34 surveys (figs. B-12, B-13) compared well to the EM-31 surveys (figs. B-10, B-11); however, differences existed between the two instruments and between the different dipole orientations in the EM-34. As with the EM-31 surveys, the EM-34 surveys delineated brine plumes associated with the tank battery (264), oil well 21056 (128), and oil well 21007 (124). However, the magnitudes of EM-34 apparent conductivity measurements generally were lower than the EM-31 apparent conductivity measurements. Additionally, the EM-34 measurements in the vertical dipole orientation (fig. B-13) were lower than the measurements in the horizontal dipole orientation (fig. B-12), especially in areas with elevated apparent conductivities associated with brine plumes. This implies a stratigraphic control on the migration of brine-contaminated groundwater in glacial outwash deposits overlying glacial till.

Elevated apparent conductivity measurements were recorded in the slough below the tank battery as far downgradient as the likely extent of this groundwater plume, between monitoring well 264T and wetland 264P (figs. B-12, B-13). Measurements in the horizontal dipole orientation from the 10-, 20-, and 40-m intercoil spacings had maximum values of 250,230 , and $260 \mathrm{mS} / \mathrm{m}$, respectively. Respective maximum measurements in the vertical dipole orientation were 78, 69, and $62 \mathrm{mS} / \mathrm{m}$. Apparent conductivities generally decreased moving downgradient in both the horizontal and vertical dipole orientations, with the exception of a large increase in apparent conductivities measured with all surveys between monitoring wells $264 \mathrm{~S}$ and $264 \mathrm{~T}$. This increase likely is from the influence of a buried glaciolacustrine deposit that was observed at the base of these wells during drilling. The elevated conductivity measurements in the horizontal dipole orientation strongly suggest a brine plume in the coarsegrained outwash sediments in the slough. The high CI values observed in 2009 from monitoring wells 264A (0.409), 264D (0.317), 264Q (0.315), 264S (0.304), and 264T (0.222), and RAB2 (0.246), which are all completed within the outwash sediments, confirm the presence of extremely and moderately contaminated groundwater in the near-surface outwash sediments. In contrast, the lower conductivity measurements in the vertical dipole orientation imply that the penetration of contaminated groundwater into the till that underlies the outwash sediments is minimal. However, no monitoring wells were completed within the underlying till to confirm the presence (and magnitude) or absence of contaminated groundwater.

Elevated apparent conductivities were recorded east of monitoring well 264T, through wetland 264P and monitoring well 264R, to the edge of West Goose Lake (figs. B-12, $\mathrm{B}-13)$. The source of the elevated conductivity is likely brine from oil well 21056 (128); however, the surficial clay deposits in wetland 264P and near West Goose Lake probably contribute to the high apparent conductivities observed in these areas. The presence of moderately contaminated groundwater was confirmed by the CI value of monitoring well 264R (0.212), which is completed in the outwash deposits. The horizontal dipole surveys had greater apparent conductivity measurements than the vertical dipole surveys, with this increase also suggesting that the brine plume is mainly confined within the surficial outwash deposits.

The EM-34 surveys also recorded elevated apparent conductivities suggesting a brine plume emanating from oil well 21007 (124) that has migrated to West Goose Lake (figs B-12, B-13). Maximum apparent conductivity measurements from the 10-, 20-, and 40-m horizontal dipole orientation were 280, 250, and $259 \mathrm{mS} / \mathrm{m}$, respectively. Respective maximum measurements from the vertical dipole orientation were 102 , 93, and $108 \mathrm{mS} / \mathrm{m}$. The sharp drop in conductivity between the horizontal and vertical dipole orientations also is interpreted as minimal penetration into the glacial till beneath the outwash deposits. The presence of extremely and moderately contaminated groundwater within the surficial outwash deposits was confirmed by the CI values from monitoring wells $124 \mathrm{C}$ (0.309), 124H (0.390), 124J (0.344), $124 \mathrm{O}$ (0.387), and 124P (0.321), all of which are completed in the outwash deposits. 

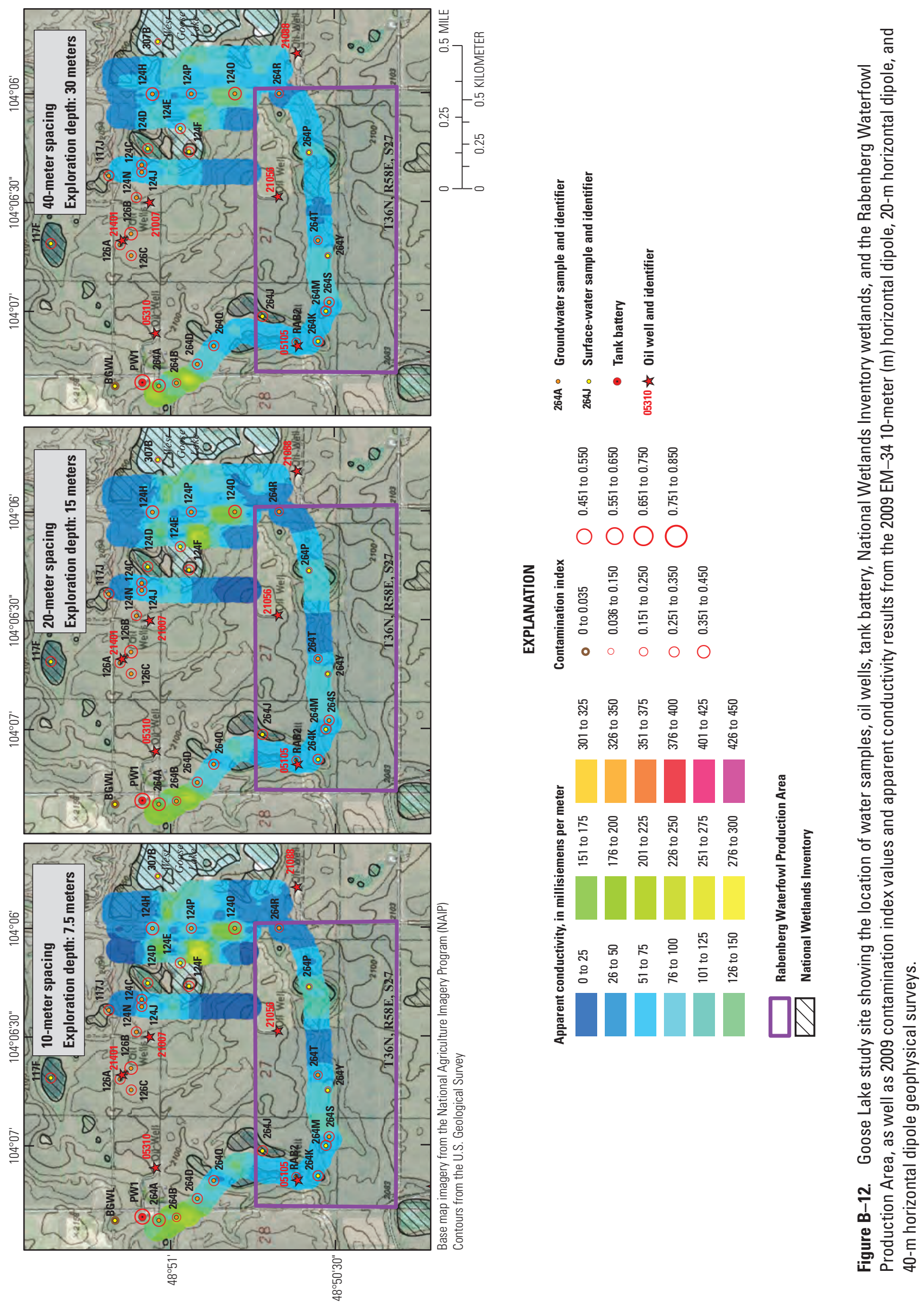

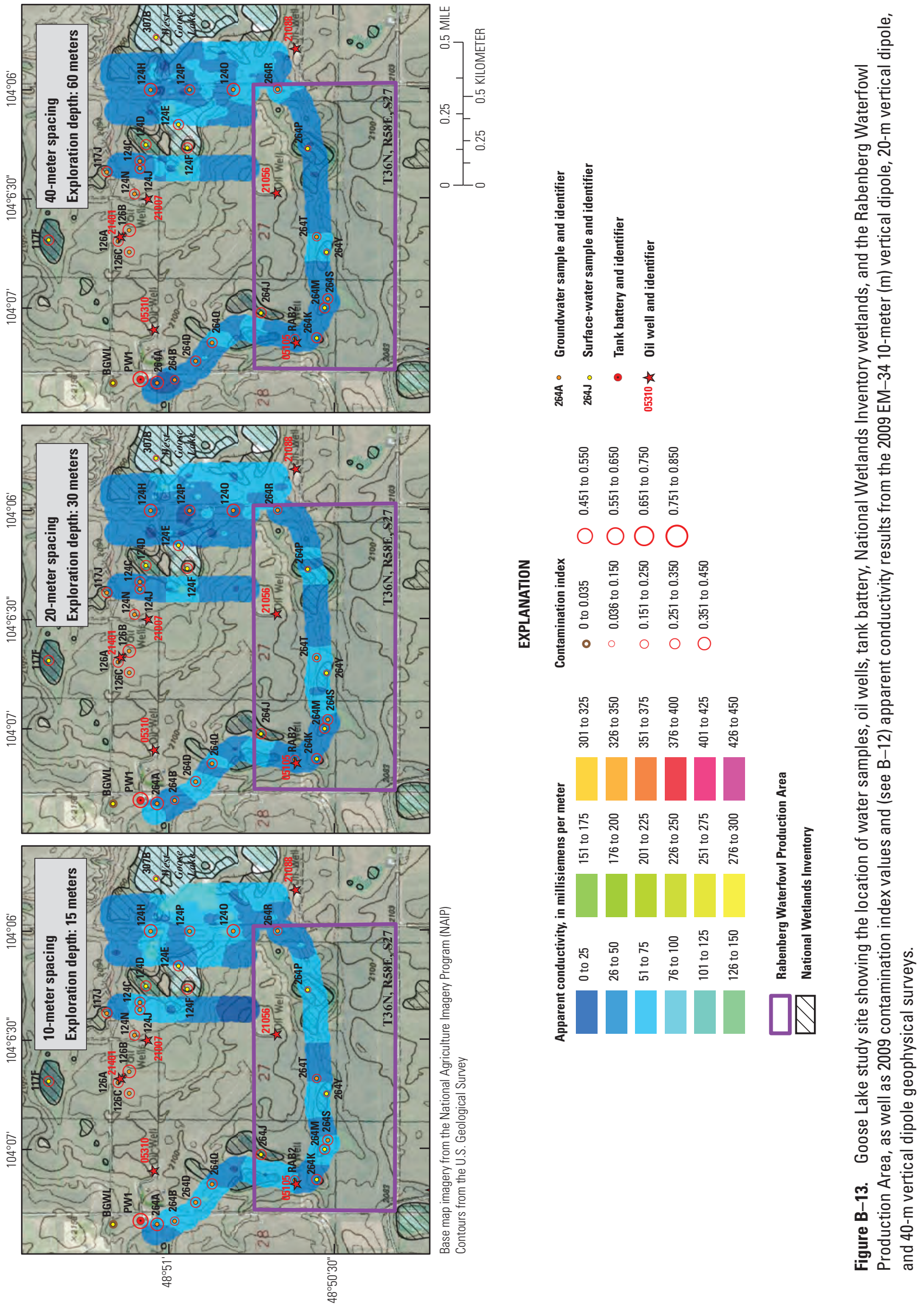
From the EM-34 surveys and CI values, it appears that the groundwater plume bifurcates around $124 \mathrm{P}$, where well logs indicate a subsurface glacial till high, further illustrating the control that the underlying till has on the transport of brinecontaminated groundwater.

Results from the EM-34 surveys show that the brine contamination at the Goose Lake study site is mainly confined within the saturated coarse-grained outwash deposits, with minimal penetration into the less permeable, underlying till. This is especially evident beneath the tank battery, where some of the largest horizontal dipole apparent conductivities were measured. In contrast, the vertical dipole measurements beneath the tank battery were much lower, with several measurements near background levels. Monitoring well 264A had the highest $\mathrm{Cl}^{-}$concentration of all sampled sites in 1989 (66,900 mg/L), 2005 (30,841 mg/L), and 2009 (37,500 mg/L) and $\mathrm{CI}$ values indicting extremely contaminated groundwater in all 3 years $(0.371,0.656$, and 0.409 , respectively), illustrating the high degree of groundwater contamination within the outwash deposits. Therefore, the sharp drop in conductivity values between the horizontal and vertical dipole orientation measurements likely is from minimal penetration of contaminated groundwater into the underlying till. Although some penetration has likely occurred, without groundwater samples from the till, the depth of penetration is impossible to fully determine. However, from the EM-34 data, it appears that the depth of contamination is clearly less than $60 \mathrm{~m}$ and likely less than $30 \mathrm{~m}$.

\section{Anderson Study Site}

\section{EM-31 Geophysical Surveys}

Several areas of elevated apparent conductivities associated with and suggesting brine plumes were measured with the EM-31 surveys at the Anderson study site in 2004 and 2010 (figs. B-14, B-15). The largest apparent conductivity values in 2004 were measured in the basins of wetlands AND4 and AND11 (475 and $485 \mathrm{mS} / \mathrm{m}$, respectively), both located southwest of the tank battery and near oil well $21351(475 \mathrm{mS} / \mathrm{m})$. The largest apparent conductivity values in 2010 were measured near oil well $21351(310 \mathrm{mS} / \mathrm{m})$ and between monitoring

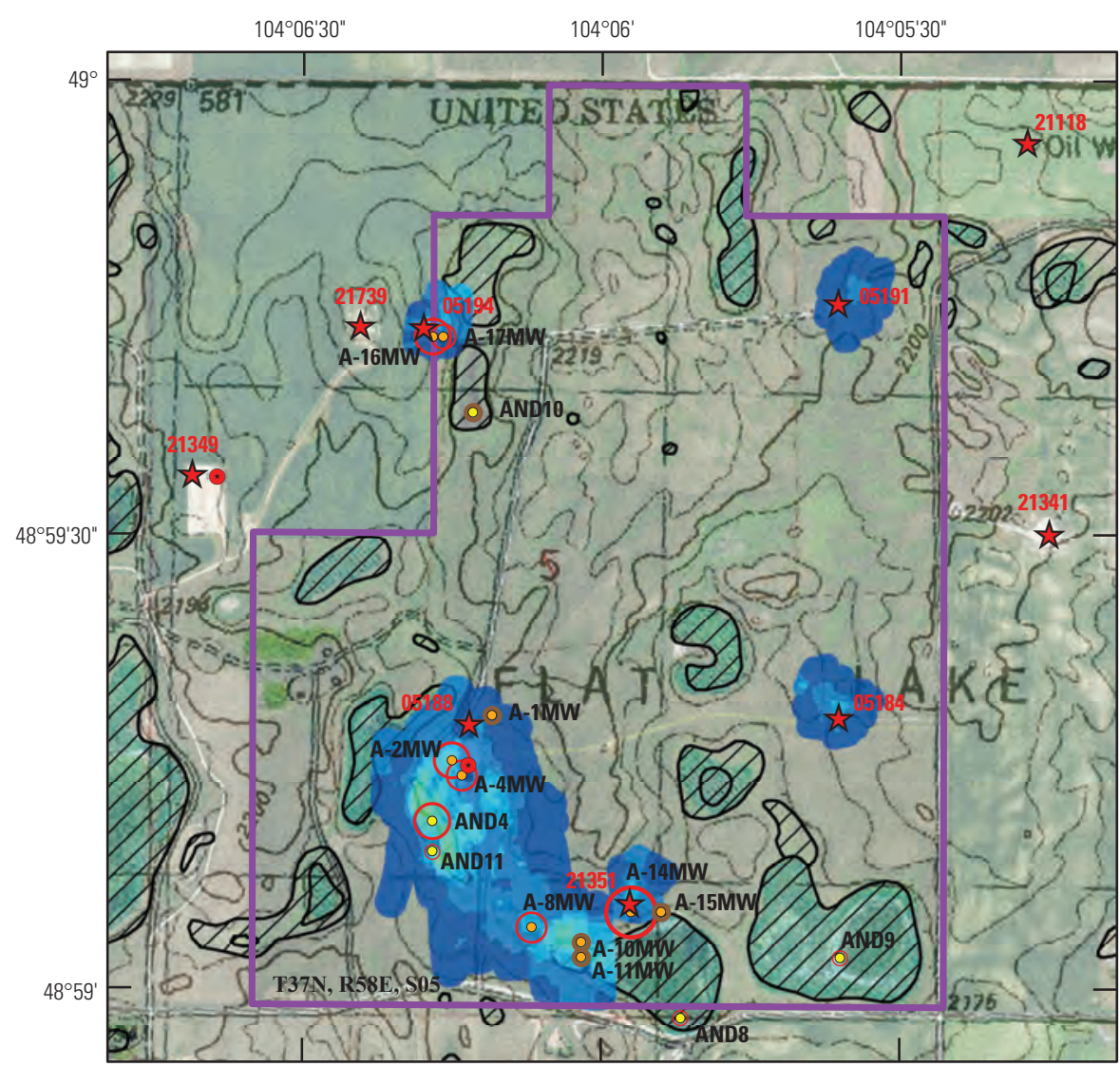

Base map imagery from the National Agriculture Imagery Program (NAIP) Contours from the U.S. Geological Survey

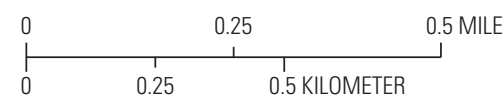

\section{EXPLANATION}

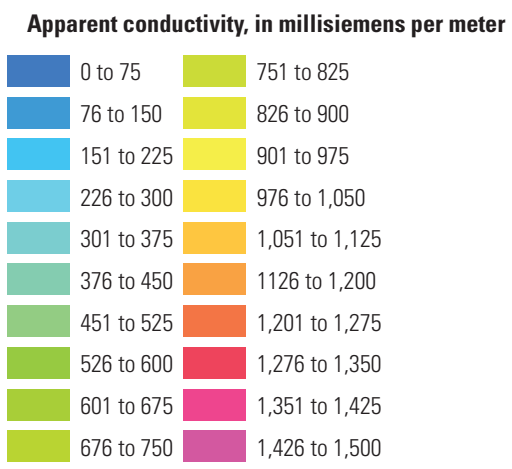

Anderson Waterfowl Production Area

National Wetlands Inventory

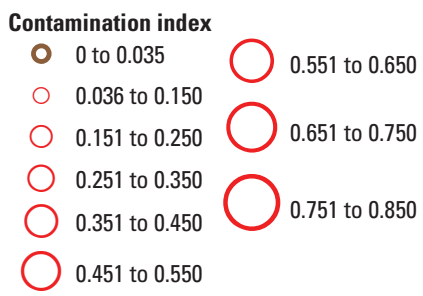

- Tank battery

A-17MW $\circ$ Groundwater sample and identifier AND10 ○ Surface-water sample and identifier 21739 亿 0 il well and identifier

Figure B-14 Anderson study site showing the location of water samples, oil wells, tank battery, National Wetlands Inventory wetlands, and the Anderson Waterfowl Production Area, as well as the 2004-5 contamination index values and apparent conductivity results from the 2004 EM-31 geophysical surveys. 

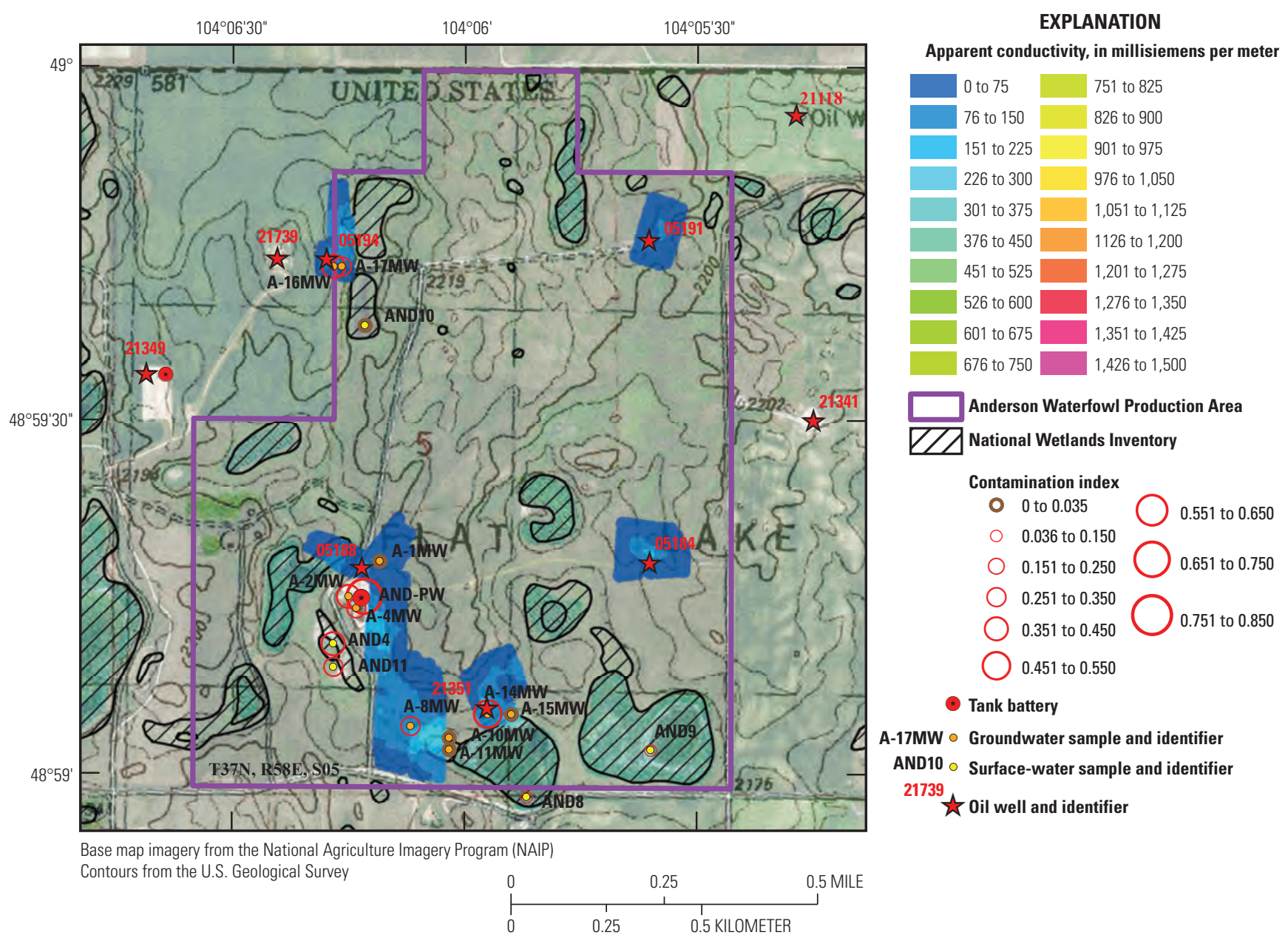

Figure B-15. Anderson study site showing the location of water samples, oil wells, tank batteries, National Wetlands Inventory wetlands, and the Anderson Waterfowl Production Area, as well as the 2010 contamination index values and apparent conductivity results from the 2010 EM-31 geophysical surveys.

wells A-8MW and A-10MW (300 mS/m). The area southwest of the tank battery was not surveyed with the EM-31 in 2010; however, this area was surveyed with the GEM-2. Additionally, elevated apparent conductivity values were measured near all oil well sites in 2004 and 2010; however, the apparent conductivity values measured in 2010 generally were lower than the values measured in 2004 across the study site.

The elevated apparent conductivity values south and east of the tank battery in 2004 and 2010 suggest a brine plume emanating from near the tank battery and extending as far down as the surveys were performed, near wetland AND8 (figs. B-14, B-15). The tank battery as the source of the contamination is supported by 2005 and $2010 \mathrm{CI}$ values (table B-2) indicating uncontaminated groundwater from monitoring well A-1MW (0.005 in both years) upgradient from the tank battery compared to moderately and extremely contaminated groundwater from monitoring wells A-2MW ( 0.510 and 0.365 , respectively), A-4MW (0.362 and 0.266, respectively), and A-8MW (0.355 and 0.332, respectively) downgradient from the tank battery. The downgradient migration or dilution of the brine plume is supported by decreased CI values in the upgradient end of the plume at monitoring wells A-2MW (-0.145), A-4MW (-0.096), and A-8MW (-0.023) between 2005 and 2010. Interestingly, the 2005 and $2010 \mathrm{CI}$ values from monitoring wells A-10MW (0.016 and 0.011 , respectively) and A-11MW (0.015 and 0.021 , respectively) documented uncontaminated groundwater despite the presence of elevated apparent conductivities measured with the 2004 and 2010 EM-31 surveys. In contrast, the 2004 and $2010 \mathrm{CI}$ values of surface-water samples from wetlands AND8 (0.098 and 0.076, respectively) and AND9 ( 0.144 and 0.095 , respectively) indicated potentially and moderately contaminated surface water; however, the source of this contamination is unclear and discussed below.

A brine plume is implied near abandoned oil well 21351 from the elevated apparent conductivity values in 2004 and 2010 that delineate a brine plume emanating from the oil well pad and extending to the north and east (figs. B-14, B-15). Maximum measured apparent conductivity readings at this site showed the largest decrease between 2004 and 2010, 
with maximum measured apparent conductivities of 475 and $310 \mathrm{mS} / \mathrm{m}$, respectively. The presence of brine was confirmed by CI values from monitoring well A-14MW that indicated extremely contaminated groundwater. Indeed, A-14MW, which is completed within and directly below the buried reserve pit for oil well 21351, recorded the largest CI value measured at the Anderson study site in 2005 and 2010 (0.823 and 0.492, respectively), as well as the greatest reduction in $\mathrm{CI}$ value (-0.331) between 2005 and 2010. The reduction in apparent conductivity measurements between 2004 and 2010 and CI values between 2005 and 2010 is likely the result of continued downgradient migration or dilution of the brine plume. Based on the direction of brine plume migration from oil well 21351 and the lower ${ }^{87} \mathrm{Sr} /{ }^{86} \mathrm{Sr}$ values of wetlands AND8 and AND9 relative to monitoring well A-14MW, the likely source of contamination in AND8 and AND9 is not the buried reserve pit at oil well 21351. However, the lack of contamination in monitoring wells A-10MW and A-11MW likely precludes the tank battery as the source of brine. Therefore, the brine source to AND8 and AND9 is unclear and may be from two other oil wells completed in the Ratcliffe Formation (21361 and 05174 and not shown on figs. B-14 and B-15) and located approximately $0.3 \mathrm{~km}$ to the south of AND8 and AND9.

Elevated apparent conductivity values were measured in 2004 and 2010 near oil well 05194 that likely define a brine plume that emanates near the oil well pad and heads northward into the wetland (figs. B-14, B-15). The largest measured values in 2004 and 2010 occurred near the well pad, with measured values of 320 and $260 \mathrm{mS} / \mathrm{m}$, respectively. The 2005 and $2010 \mathrm{CI}$ values from monitoring wells A-16MW $(0.485$ and 0.424 , respectively) and A-17MW (0.272 and 0.257 , respectively) confirm the presence of extremely and moderately contaminated groundwater as the source of elevated apparent conductivities. Although the maximum conductivity value in 2010 was still extremely elevated compared to background conductivity, the reduction in maximum apparent conductivity values relative to 2004 likely indicates a reduction in the magnitude of contamination because of downgradient migration or dilution of the contaminated groundwater. This interpretation is supported by groundwater data from A-16MW and A-17MW (table B-2), where a reduction in CI values (-0.021 and -0.015 , respectively) was observed between 2004 and 2010.

A similar decrease in maximum apparent conductivity values was observed at oil wells 05184 and 05191 between 2004 and 2010 (figs. B-14, B-15). At both oil wells, elevated apparent conductivity values suggest a brine plume adjacent to the well pads. The maximum apparent conductivity values for 2004 and 2010 at oil well 05184 were 230 and $210 \mathrm{mS} / \mathrm{m}$, respectively. Respective maximum apparent conductivity values for 2004 and 2010 at oil well 05191 were 130 and 100 $\mathrm{mS} / \mathrm{m}$. As with oil well 05194 , the reduction in the maximum measured apparent conductivity values near oil wells 05184 and 05191 is interpreted as a reduction in the magnitude of contamination, likely from downgradient migration or dilution; however, no groundwater data were available for these sites to confirm this conclusion.

\section{GEM-2 Geophysical Surveys}

The relative trends in all frequencies from the GEM-2 surveys (fig. B-16) compared well to the EM-31 surveys in 2004 and 2010 (figs. B-14, B-15), although the two instruments measure earth conductivity differently. As with the EM-31 surveys, brine plumes were suggested from the GEM-2 survey to be emanating from the tank battery and near oil wells 21351, 05194, 05184, and 05191. However, apparent conductivity measurements were generally much greater in the GEM-2 surveys relative to the EM-31 surveys in some areas suggesting brine contamination. Lastly, in contrast to the EM-34 surveys at the Goose Lake study site that showed large drops in conductivity at shallow depth, the GEM-2 surveys at Anderson were very consistent between different exploration depths. This implies a lack of stratigraphic control on the migration of brine in glacial till deposits.

Brine-contaminated groundwater was indicated from elevated apparent conductivities measured to the southeast and southwest of the tank battery and extending as far southeast as wetland AND9 (fig. B-16). All frequencies from the GEM-2 surveys recorded elevated apparent conductivities emanating from the tank battery with respective maximum apparent conductivities from the 93,030, 47,970, and $1,530 \mathrm{~Hz}$ frequencies of 1,580, 1,510 and 1,175 mS/m near wetland AND4. Despite slightly different maximum apparent conductivity values, no substantial difference in the overall apparent conductivity profiles existed between any of the frequencies used in the GEM-2 surveys. Extremely and moderately contaminated groundwater as the source of elevated apparent conductivities was confirmed by the $\mathrm{CI}$ values from monitoring wells A-2MW (0.365), A-4MW (0.266), and A-8MW (0.332) in 2010 (table B-2). Similar to the EM-31 surveys, elevated apparent conductivities also were measured near monitoring wells A-10MW and A-11MW, although CI values from both wells were below 0.035 , indicating uncontaminated groundwater. The CI values of surface-water samples from wetlands AND8 (0.076) and AND9 (0.095) indicated potential contamination; however, as discussed previously, the brine source is unclear.

Elevated apparent conductivity measurements from all frequencies were recorded near oil well 21351 and delineated a brine plume emanating from the oil well pad and migrating to the north and east (fig. B-16). Maximum apparent conductivities from the $93,030,47,970$, and $1,530 \mathrm{~Hz}$ frequencies $(650,800$, and $680 \mathrm{mS} / \mathrm{m}$, respectively) were measured on the oil well pad and likely denote the location of the buried reserve pit. Despite slightly different maximum apparent conductivity values, no substantial differences in the overall apparent conductivity profiles existed between any of the frequencies used in the GEM-2 surveys. The presence of extremely contaminated groundwater as the source of elevated apparent conductivities was confirmed by the $2010 \mathrm{CI}$ value from monitoring well A-14-MW (0.492). As with the EM-31 surveys at oil well 21351, the direction of the brine plume 

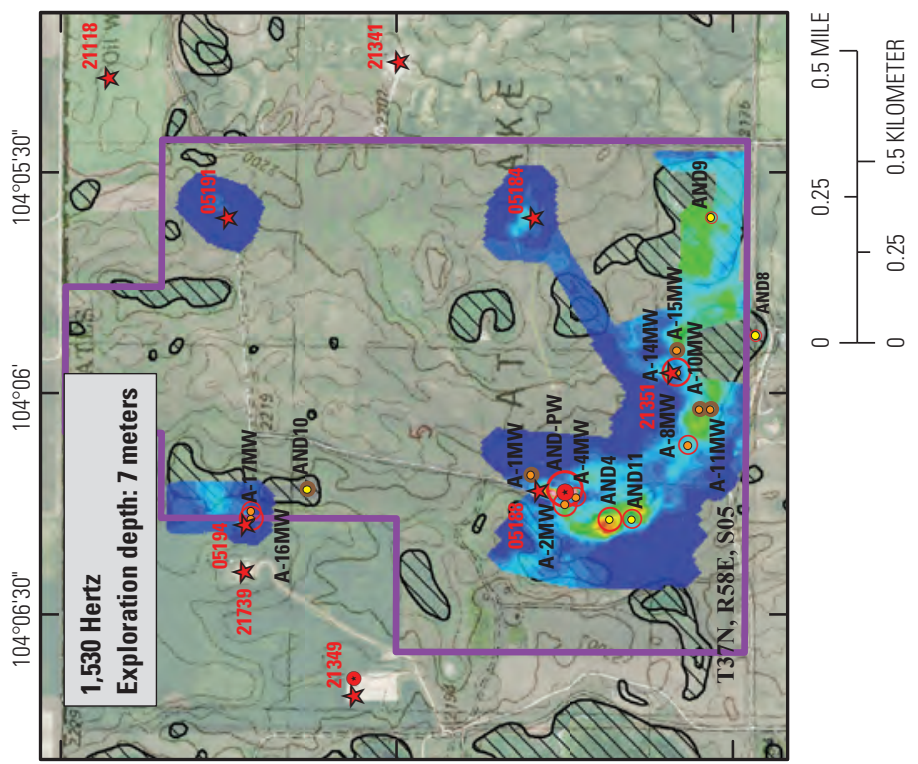

룽
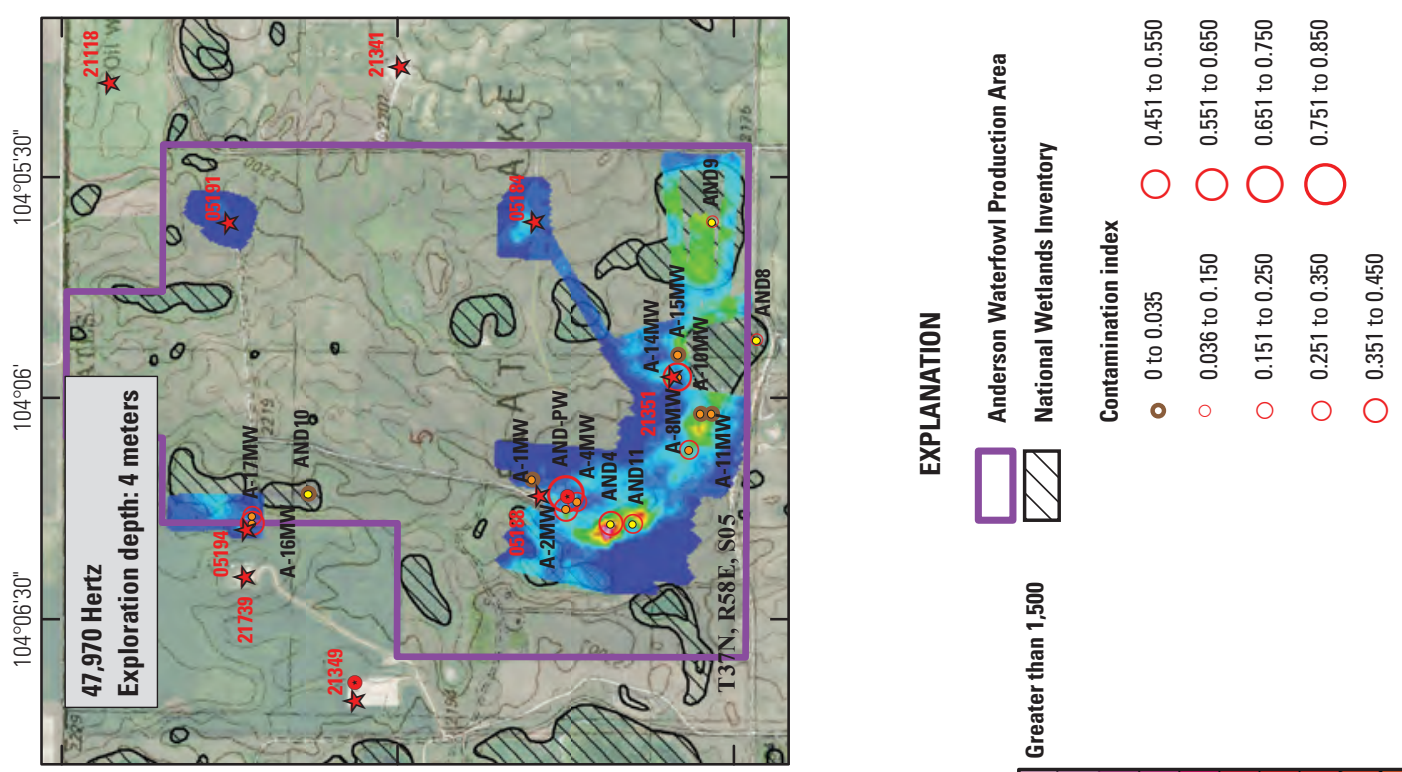

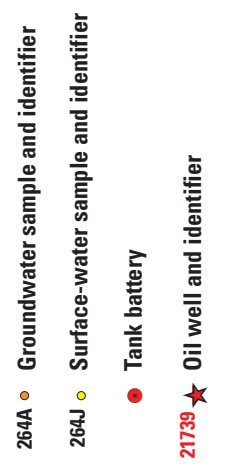

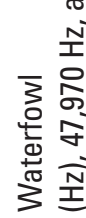

동

등 용

\%

듣

㐫

क

莽

$\geq$

곤

릉

co

든

元

즏음

은 은

के

䑻

壱

壱

क)

可
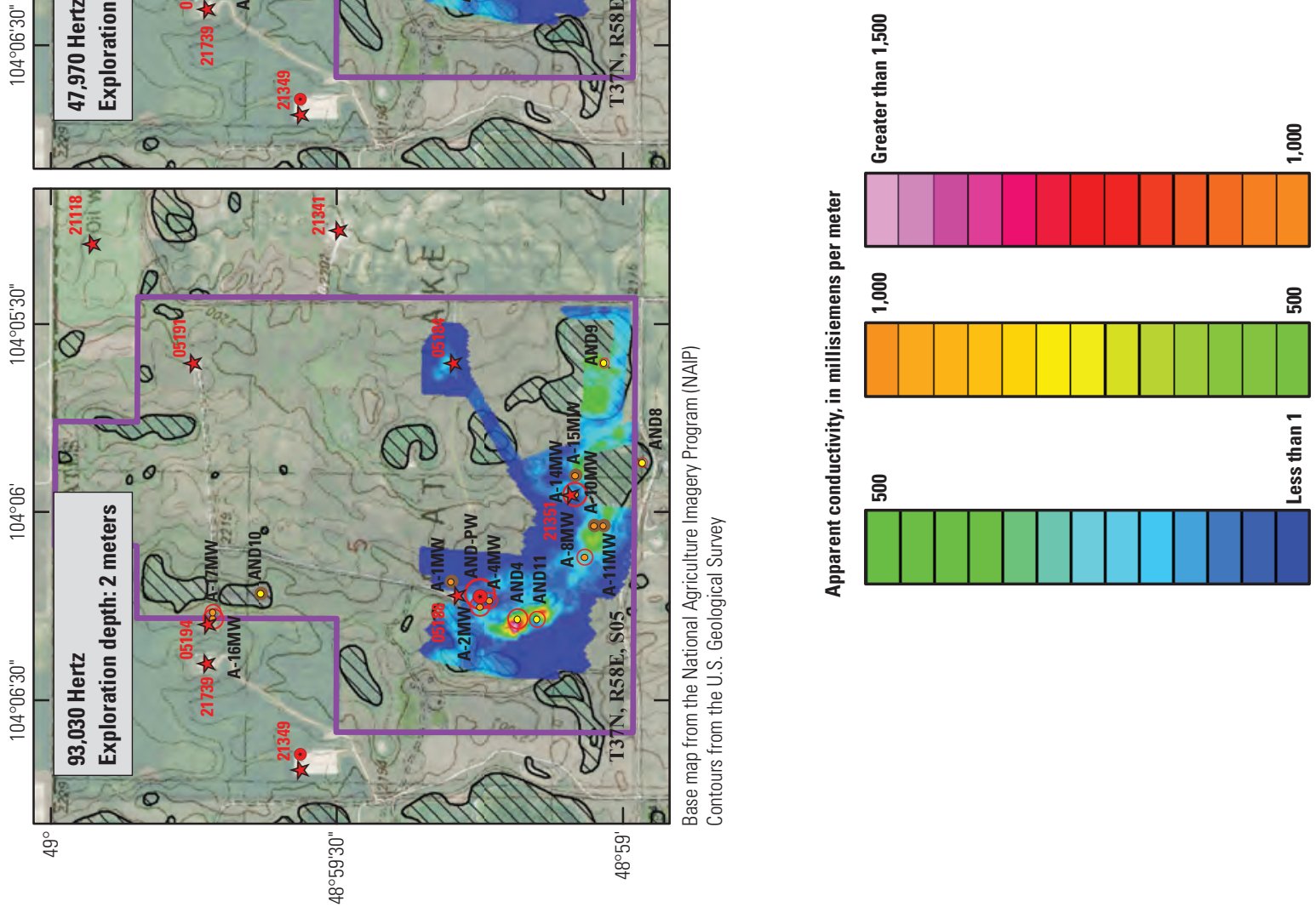

造 䓂

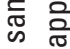

क्षे

3 过

들 익

产 ख

으.

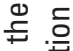

을.

产

कs

.

증응

蛋品

등

흥

完

○荌

들

m

능 응

한은 눈 
movement indicates that the buried reserve pit at this well is not the source of contamination in wetlands AND8 and AND9.

The GEM-2 data near oil well 05194 indicated a brine plume emanating from the oil well pad and extending into the wetland basin to the northeast (fig. B-16). Maximum apparent conductivities from the 1,530 and $47,970 \mathrm{~Hz}$ frequencies (300 and $200 \mathrm{mS} / \mathrm{m}$, respectively) were measured near the oil well pad and likely define the location of the buried reserve pit. GEM-2 data in the 93,030 Hz frequency were not collected near oil well 05194 . No substantial differences in the overall apparent conductivity profiles existed between the 1,530 and 47,970 frequencies despite the slightly different maximum apparent conductivity values. The presence of brine as the source of elevated apparent conductivity was confirmed by the $2010 \mathrm{CI}$ values from monitoring wells A-16MW (0.424) and A-17MW (0.257) (table B-2) that indicated extremely and moderately contaminated groundwater, respectively.

Elevated apparent conductivity values also were measured near oil wells 05184 and 05191 (fig. B-16). Respective maximum apparent conductivities from the 93,030, 47,970, and $1,530 \mathrm{~Hz}$ frequencies were 300,360 , and $320 \mathrm{mS} / \mathrm{m}$ near oil well 05184. Maximum apparent conductivities near oil well 05191 from the 1,530 and $47,970 \mathrm{~Hz}$ frequencies were 85 and $75 \mathrm{mS} / \mathrm{m}$, respectively. GEM-2 data for the $93,030 \mathrm{~Hz}$ frequency were not collected near oil well 05191. Again, no major differences were seen in the overall apparent conductivity profiles between the different frequencies near these two oil wells. No groundwater samples were collected within the areas of high apparent conductivities near these oil wells to confirm the presence of groundwater contamination. However, the strong correlation between elevated apparent conductivities and groundwater contamination observed across the Anderson study site indicates that brine contamination is likely.

In contrast to the EM-34 surveys at the Goose Lake study site (figs. B-12, B-13), which showed a marked reduction in apparent conductivity with depth that implies a subsurface control (the contact between the underlying till and surficial outwash deposits) on the migration of brine plumes, the GEM-2 surveys at the Anderson study site show no such systematic reduction in apparent conductivity with depth (fig. B-16). The lack of a reduction in apparent conductivity is interpreted as evidence of a lack of subsurface control on the vertical migration of brine in glacial till deposits. Therefore, without this subsurface control, the contamination is likely migrating horizontally and vertically at the Anderson study site compared to the predominately horizontal migration in the outwash deposits at the Goose Lake study site. Indeed, the distances of contaminant migration at the Goose Lake site were about 600 and 800 $\mathrm{m}$, whereas at the Anderson site, the distance of migration was approximately $400 \mathrm{~m}$. However, the depths of exploration for the GEM-2 (2-7 m) are much less than the EM-34 (7.5-60 m); therefore, reductions in apparent conductivity may exist in the glacial till deposits at greater depths than measured.

\section{Fuller Study Site}

\section{EM-31 Geophysical Surveys}

Areas of elevated apparent conductivity suggesting brine plumes were measured with the EM-31surveys at the Fuller study site in 2010 (fig. B-17). Background apparent conductivity values were slightly higher at the Fuller study site, in the range of $25-50 \mathrm{mS} / \mathrm{m}$, with the higher values likely because of the greater clay content of the glaciolacustrine deposits. The largest apparent conductivity values were measured near the tank battery and oil well 01057 . Additionally, elevated apparent conductivities were measured across much of the surveyed area. No previous geophysical surveys had been performed at the Fuller site for comparison with the 2010 survey.

The elevated apparent conductivities measured near the tank battery and oil well 01057 likely indicate brine plumes associated with these oilfield sites (fig. B-17). Respective maximum apparent conductivity values near the tank battery and oil well 01057 were 300 and $240 \mathrm{mS} / \mathrm{m}$ and likely denote the locations of buried reserve pits associated with these facilities. Although no groundwater samples were collected from these locations, the highly elevated apparent conductivities at these sites and the strong correlation between elevated apparent conductivity and brine contamination seen at the Goose Lake and Anderson study sites indicate likely groundwater contamination near the oilfield facilities at the Fuller site as well.

Elevated apparent conductivities also were measured in the slough west of the reservoir, where surface-water sample FULL-A was collected, and extended to the location of wetland FULL-B (fig. B-17). The CI value from monitoring well FULL-MW-2 (0.044) indicates potentially contaminated groundwater underlying the slough. Elevated apparent conductivities were measured in the majority of the surveyed area west of the tank battery and oil well 01057 , with measured values as high as $135 \mathrm{mS} / \mathrm{m}$ near where the slough meets the lake plain. Although the CI value at monitoring well FULLMW-1 (0.015) indicated uncontaminated groundwater, this sample had the greatest $\mathrm{Cl}^{-}$concentration $(350 \mathrm{mg} / \mathrm{L})$ of all water samples from the Fuller study site.

\section{GEM-2 Geophysical Surveys}

Although differences existed between the two instruments, the relative trends in all frequencies from the GEM-2 surveys (fig. B-18) compared well to the EM-31 surveys (fig. B-17). As with the EM-31 surveys, elevated apparent conductivities suggesting brine-contaminated groundwater were measured near the tank battery, oil well 01057, and in the slough west of the reservoir where surface-water sample FULL-A was collected. An additional area of elevated apparent conductivity also was measured on the lake plain. Apparent conductivity measurements generally were greater in the GEM-2 surveys relative to the EM-31 surveys in areas suggesting brine contamination. Lastly, in contrast to the GEM-2 surveys at the Anderson study site that showed similar 

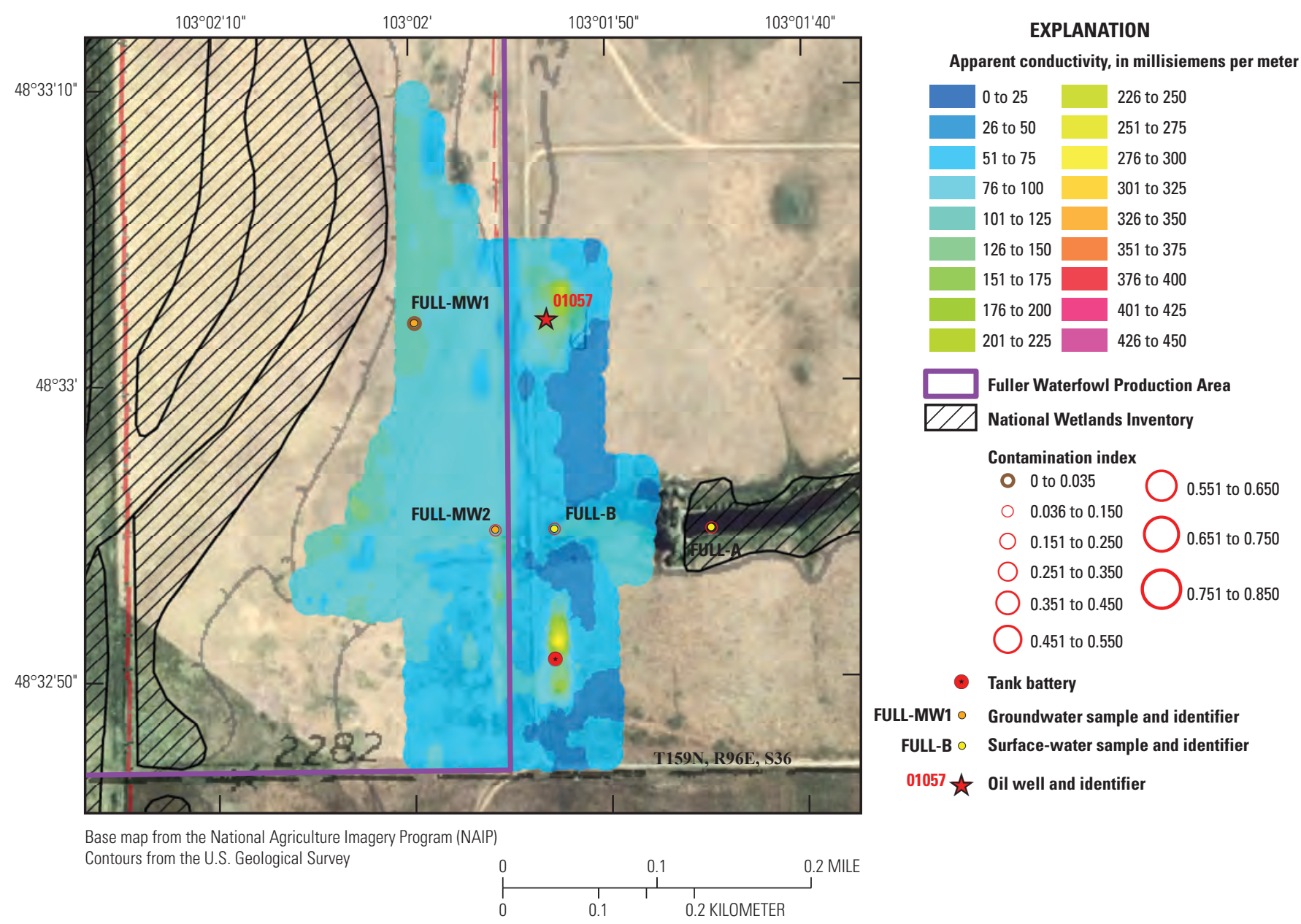

Figure B-17. Fuller study site showing the location of water samples, oil well 01057, tank battery, National Wetlands Inventory wetlands, and the Fuller Waterfowl Production Area boundary, as well as the 2010 contamination index values and apparent conductivity results from the $2010 \mathrm{EM}-31$ geophysical survey.

maximum apparent conductivity values with depth, increases in the maximum apparent conductivity values and the area of elevated conductivity were observed with depth at the Fuller study site. The increase in maximum apparent conductivity values and area of elevated conductivity implies a possible stratigraphic control on the migration of brine-contaminated groundwater in glaciolacustrine deposits.

Elevated apparent conductivities were measured near the tank battery and oil well 01057 and indicate groundwater contamination related to these facilities (fig. B-18). Respective maximum apparent conductivities from the 93,030, 47,970 , and $1,530 \mathrm{~Hz}$ frequencies were 750,950 , and 1,955 $\mathrm{mS} / \mathrm{m}$ near the tank battery and 260,360 and $530 \mathrm{mS} / \mathrm{m}$ near oil well 01057 . Areas of maximum elevated apparent conductivity at the tank battery and oil well 01057 likely denote the locations of buried reserve pits. Extremely high values of apparent conductivity at the tank battery may reflect very high salinity of pore fluids. Groundwater samples were not collected from these areas to confirm contamination; however, the strong correlation between elevated apparent conductivities and brine contamination observed at the previous study sites indicates that brine contamination is likely. The differences between the three frequencies at both locations, namely the increase in maximum apparent conductivity values and the area of elevated conductivity with depth, may reflect increased contamination with depth.

Brine-contaminated groundwater beneath the slough where samples from wetland FULL-B and monitoring well FULL-MW2 were collected is supported by elevated apparent conductivity measurements (fig. B-18). Respective maximum apparent conductivities from the $93,030,47,970$, and $1,530 \mathrm{~Hz}$ frequencies were 160,188 , and $137 \mathrm{mS} / \mathrm{m}$. The presence of contaminated groundwater as the source of elevated apparent conductivity was suggested by the $2010 \mathrm{CI}$ value from FULL-MW2 (0.044) that indicated potentially contaminated groundwater. The continuation of this plume, below the lake plain to the west, is suggested by elevated apparent conductivity measurements in all frequencies; however, no groundwater samples were collected in this area to confirm the presence of brine. 

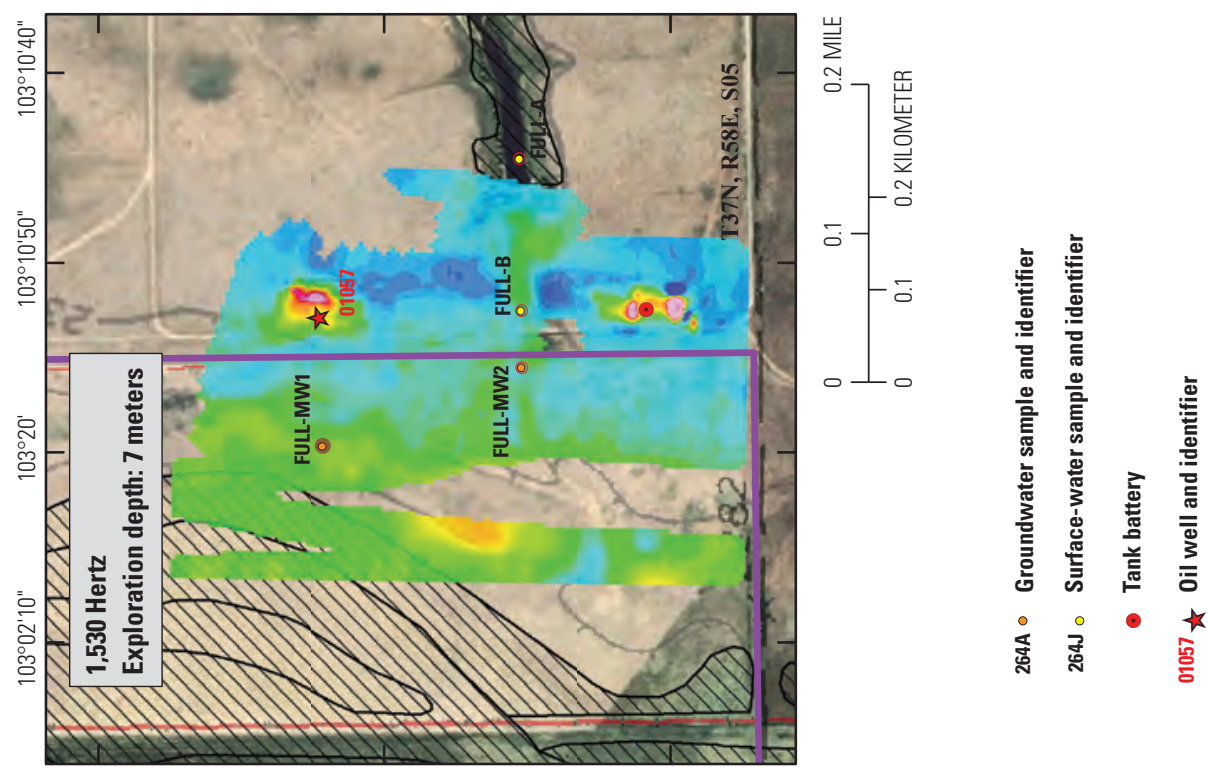

을

응

은 只

ऊ

음 Nㅗㅇ

3

흥

고 융

ฮั

믇

के पे

क क

产

3

주워ำ

드응
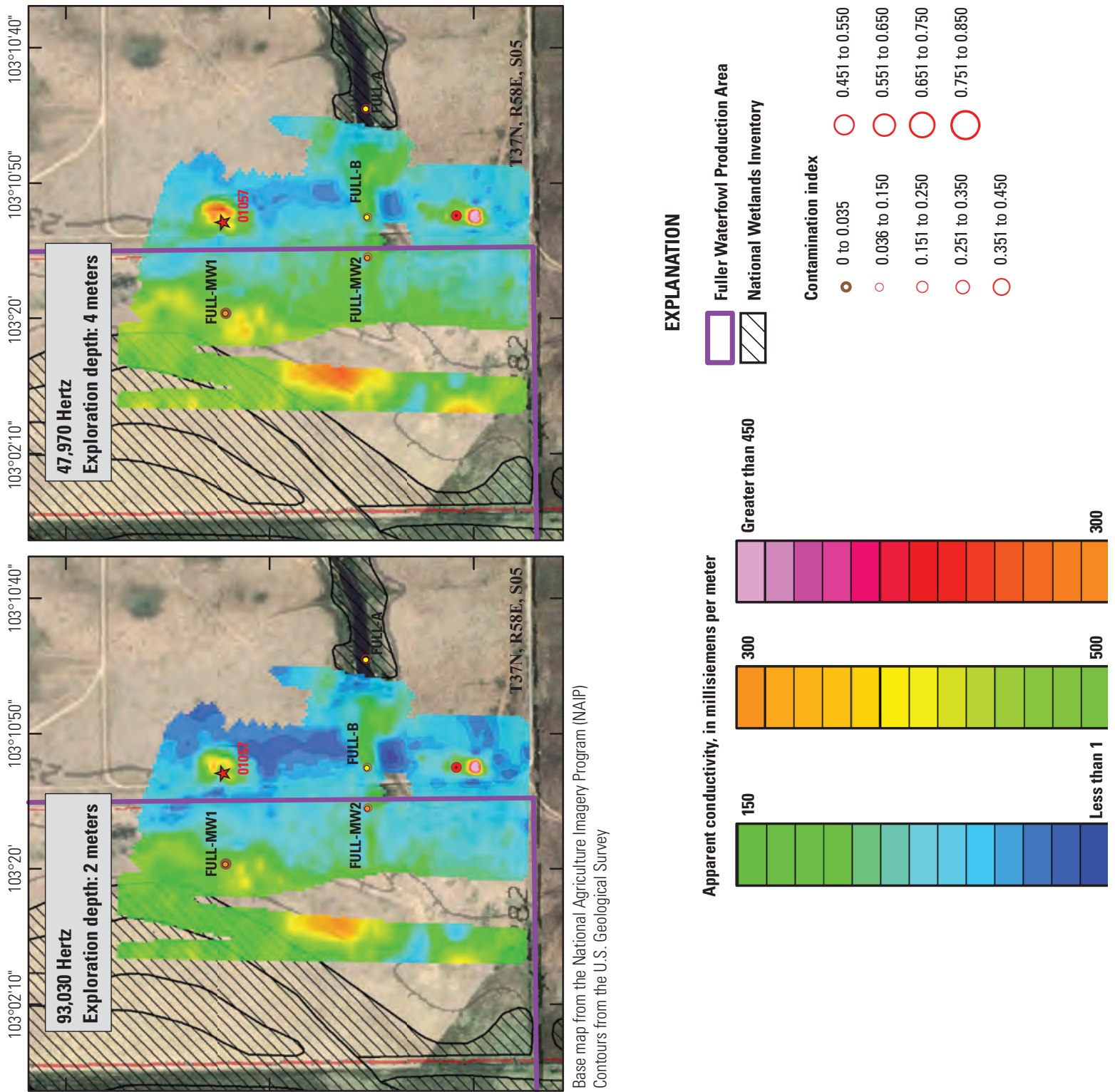

c)

壱

岕

뜽 응

苋昰

등

売

들

송 롱

응 응

$\overline{\overline{0}}$

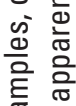

胥

ปั

苋

$3 \frac{1}{3}$

들 임

으 으

으도음

으 ह

高

응

․ㅗ $\frac{0}{\circ}$

흘 क

क

禀 孚

츨

$\infty$ 증 민

$\infty$ 은소

늘 응

름 ญํํ

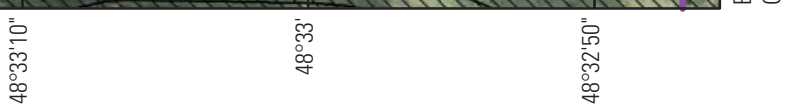


The increases in maximum apparent conductivity values with increased depth observed at the Fuller site likely imply subsurface control on the migration of brine-contaminated groundwater in lacustrine deposits that overlie glacial till (fig. B-18). Near the tank battery and oil well 01057, the maximum apparent conductivity values more than double between the $93,030 \mathrm{~Hz}$ and $1,530 \mathrm{~Hz}$ frequencies and the area of elevated conductivity slightly increases. Schwartz and Zang (2003) report that the hydraulic conductivity for weathered lacustrine deposits $\left(3.2 \times 10^{-8} \mathrm{~m} / \mathrm{s}\right)$ is generally lower than the hydraulic conductivity of fractured glacial till (range of 1.2 $\times 10^{-5}$ to $1.2 \times 10^{-9} \mathrm{~m} / \mathrm{s}$ ). Therefore, it would be expected that the vertical component of brine migration would be greater in the lacustrine deposits relative to the glacial till deposits. In contrast, the horizontal component of brine migration would be the opposite, with greater lateral migration in the glacial till deposits. This is likely the reason for the increase in apparent conductivity values and greater area of elevated conductivity in the $1,530 \mathrm{~Hz}$ frequency relative to the $93,030 \mathrm{~Hz}$ frequency near the tank battery and oil well 01057 . Therefore, in areas where lacustrine deposits overlie glacial till, it appears that the direction of brine migration is predominately vertical in the lacustrine deposits and becomes more horizontal once it reaches the underlying glacial till. The predominantly vertical migration of brine in the lacustrine deposits is further supported by a lack of laterally extensive brine plumes at the Fuller site compared to those seen at both the Goose Lake and Anderson sites. Although this conclusion follows the principals of groundwater flow through a heterogeneous medium (Schwartz and Zang, 2003), it cannot be confirmed because of a lack of groundwater quality and lithological data on the magnitude of brine contamination with depth and the depth of the contact between the lacustrine and glacial till deposits, respectively, near the tank battery and oil well 01057.

\section{Summary-Brine Contamination of Prairie Pothole Environments in the Williston Basin}

The presence of brine in surface water and shallow groundwater was documented at three study sites within the Prairie Pothole Region (PPR) in the Williston Basin during 2009-10. The likely brine source is water produced with oil in the Williston Basin. At the Goose Lake site, water-quality results from 26 of 29 surface-water and shallow groundwater samples collected during 2009 indicated moderate or extreme brine contamination, with 2 additional samples indicating potential contamination. The only sample with a contamination index (CI) value less than 0.035 was collected from a small wetland located upgradient from potential contaminant sources. At the Anderson site, water-quality results from 8 of the 15 surface-water and shallow groundwater samples collected during 2010 indicated moderate or extreme brine contamination, with 2 additional samples indicating potential contamination. At the Fuller site, water-quality results from three of the four surface-water and shallow groundwater samples collected during 2010 indicated potential brine contamination. Based on the results at these three sites, brine contamination in surface water and shallow groundwater located in close proximity to oilfield facilities in the PPR in the Williston Basin is more likely than in areas isolated from oil and gas development activities, and once brine is present in these systems, it can persist for several decades.

Study sites with previously documented brine contamination (Goose Lake in 1989 and 2004-6 and Anderson in 2004-5) were still contaminated when visited in 2009 or 2010. Brine contamination has persisted for at least 20 years at the Goose Lake site and for at least 6 years at the Anderson site. The brine is likely leached from buried reserve pits that were installed in the mid- to late-1960s, indicating that contamination has likely persisted for four to five decades at both study sites. Further illustrating the length of time required for natural attenuation of brine in the PPR, a statistically significant reduction in the magnitude of contamination was seen over 20 years at the Goose Lake site while no statistically significant reduction was observed over 5-6 years at the Anderson site.

The lateral migration of brine plumes appears to be controlled, in part, by the type of near-surface sediments. Based on the distribution of sample sites at two of the three study sites, brine contamination migrated at least 600 and 800 meters $(\mathrm{m})$ along two separate groundwater-flow paths in coarse-grained glacial outwash deposits (Goose Lake study site) and at least $400 \mathrm{~m}$ along a groundwater-flow path in fine-grained, clay-rich glacial till (Anderson site). The Fuller site did not have a groundwater-flow path long enough to determine the lateral migration of brine contamination in very fine-grained glaciolacustrine deposits; however, data from the geophysical surveys at the Fuller site did not indicate the laterally extensive brine plumes that were measured at the Goose Lake and Anderson sites. These results suggest greater lateral migration of brine plumes in the coarse-grained outwash deposits relative to the clay-rich glacial tills and glaciolacustrine deposits in the PPR. This observation is consistent with the general variation in hydraulic conductivity which is lower in fine-grained, clay-rich, sediments than in coarse-grained sediments.

Geophysical surveys performed at the three study sites measured elevated apparent conductivities near the vast majority of oilfield facilities. At the Goose Lake site, elevated apparent conductivities were measured during 2004 and 2009 in areas that include a tank battery and several oil wells. At the Anderson site, elevated apparent conductivities were measured during 2004 and 2010 in areas that include a tank battery and several oil wells. At the Fuller site, elevated apparent conductivities were measured during 2010 near the tank battery and oil well. High chloride concentrations, specific conductivity, and CI values were measured in groundwater samples from several areas of elevated apparent conductivity, indicating that brine is the likely source of elevated apparent conductivity 
in these areas and also the likely source of elevated apparent conductivities in areas adjacent to oilfield facilities without groundwater samples for verification. Therefore, geophysical surveys provide an effective method to identify areas of possible brine contamination in the PPR within similar hydrogeologic settings.

Differences were observed in the vertical migration of brine plumes in the three different types of near-surface sediments based on the geophysical surveys. At the Goose Lake site, where coarse-grained glacial outwash deposits overlie clay-rich glacial till, elevated apparent conductivity measurements associated with brine contamination decreased substantially as the exploration depth of the geophysical surveys increased. This is interpreted as minimal penetration of the brine into the underlying till. In contrast, apparent conductivity measurements did not change substantially with decreasing frequency (depth) at the Anderson site in clay-rich glacial till. This is likely from the more homogenous subsurface at the Anderson site that does not have different geologic deposits with contrasting hydraulic conductivities, resulting in a lack of preferential flow paths. Finally, maximum apparent conductivity values increased substantially, and the area of elevated apparent conductivity expanded slightly with depth at the Fuller site where silt and clay lacustrine deposits overlie glacial till. This is interpreted as a preferential vertical migration of brine though the lacustrine deposits with brine migration becoming more horizontal in the underlying glacial till. However, it should be noted that exploration depths were much greater at the Goose Lake site (EM-34, exploration depths of 7.5-60 m) relative to the Anderson and Fuller sites (GEM-2, exploration depths of 2-7 m); therefore, lower apparent conductivity may exist at greater depths than mapped by the specific electromagnetic system.

Geophysical data and analytical results indicate the source of contamination of surface water and shallow groundwater at the three study sites is brine produced with oil. Potential brine sources are oil wells, tank batteries, reserve pits, and pipelines. The geophysical and water-quality data clearly indicate that oil and gas production sites are point sources that can and do contaminate surface water and shallow groundwater in the PPR.

\section{References}

Bachu, S., and Hitchon, B., 1996, Regional-scale flow of formational waters in the Williston Basin: American Association of Petroleum Geologists Bulletin, v. 80, p. 248-264.

Beal, W.A., Murphy, E.C., and Kehew, A.E., 1987, Migration of contaminants from buried oil-and-gas drilling fluids within the glacial sediments of north-central North Dakota: North Dakota Geological Survey, Report of Investigation $86,43 \mathrm{p}$.
Corwin, D.L., and Lesch, S.M., 2005, Characterizing soil spatial variability with apparent soil electrical conductivity-I. Survey protocols: Computers and Electronics in Agriculture, v. 46, p. 103-133.

Custer, S.G., 1976, Shallow groundwater salinization of dry land farm areas of Montana: Bozeman, University of Montana, Ph.D. dissertation, $175 \mathrm{p}$.

Eisenlohr, W.S., Jr., and others, 1972, Hydrologic investigations of prairie potholes in North Dakota, 1959-68: U.S. Geological Survey Professional Paper: 585-A, 101 p.

Fishman, M.J., ed., 1993, Methods of analysis by the U.S. Geological Survey National Water Quality LaboratoryDetermination of inorganic and organic constituents in water and fluvial sediments: U.S. Geological Survey OpenFile Report 93-125, 217 p.

Greenhouse, J.P., and Slaine, D.D., 1986, Geophysical modeling and mapping of contaminated groundwater around three waste disposal sites in southern Ontario: Canadian Geotechnical Journal, v. 23, p. 373-384.

Grisak, G.E., Pickens, J.F., and Cherry, J.A., 1980, Solute transport through fractured media:2. Column study of fractured till: Water Resources Research, v. 16, p.731-739.

Hem, J.D., 1985, Study and interpretation of the chemical characteristics of natural waters: U.S. Geological Survey Water-Supply Paper 2254, 263 p.

Iampen, H.T., and Rostron, B.J., 2000, Hydrogeochemistry of pre-Mississippian brines, Williston Basin, Canada-USA: Journal of Geochemical Exploration, v. 70, p. 29-35.

Kalkhoff, S.J., 1993, Brine contamination of ground water and streams in the Baxterville oil field area, Lamar and Marion Counties, Mississippi: United States Geological Survey Water-Resources Investigations Report 93-4147, 44 p.

Kharaka, Y.K., and Hanor, J.S., 2003, Deep fluids in the continents-I. Sedimentary basins, in Drever, J.I., ed., Treatise on Geochemistry-Surface and Ground Water, Weathering, and Soils: Oxford, Elsevier Ltd., v. 5, p. 499-540. (Also available at $h t t p: / / w w w . s c i e n c e d i r e c t . c o m / s c i e n c e / a r t i c l e /$ pii/B0080437516050854.)

LaBaugh, J.W., and Swanson, G.A., 1992, Changes in chemical characteristics of water in selected wetlands in the Cottonwood Lake area, North Dakota, U.S.A., 1967-89, in Robarts, R.D., and Bothwell, M.L., eds., Aquatic ecosystems in semi-arid regions - Implications for resource management: Saskatoon, Saskatchewan, Environment Canada, The National Hydrology Research Institute Symposium Series 7, p. 149-162. 
LaBaugh, J.W., and Swanson, G.A., 2003, Spatial and temporal variability in specific conductance and chemical characteristics of wetland water and in water column biota in the wetlands in the Cottonwood Lake area, in Winters, T.C., ed., Hydrological, chemical, and biological characteristics of a prairie pothole wetland complex under highly variable climate conditions-The Cottonwood Lake area, east-central North Dakota: U.S. Geological Survey Professional Paper 1675, p. 35-53.

McArthur, J.M., Howarth, R.J., and Bailey, T.R., 2001, Strontium isotop stratigraphy-LOWESS version 3-Best fit to the marine Sr-isotope cure for 0-509 Ma and accompanying look-up table for deriving numerical age: Journal of Geology, v. 109, p. 155-170.

McNeill, J.D., 1980, Electromagnetic terrain conductivity measurement at low induction numbers: Geonics Technical Notes TN-6, accessed November 2012, at http://www. geonics.com/html/technicalnotes.html.

Moseley, H.R., 1983, Summary of API onshore drilling mud and produced water environmental studies: International Association of Drilling Contractors/Society of Petroleum Engineers Drilling Conference, February 20-23, New Orleans, La.

Murphy, E.C., 1983, The effect of oil and gas well drilling on shallow groundwater in western North Dakota: Grand Forks, University of North Dakota, Master's Thesis, 242 p.

Murphy, E.C., and Kehew, A.E., 1984, The effect of oil and gas well drilling fluids on shallow groundwater in western North Dakota: North Dakota Geological Survey Report of Investigation No. 82, $156 \mathrm{p}$.

Murphy, E.C., Kehew, A.E., Groenewold, G.E., and Beal, W.A., 1988, Leachate generated by an oil-and-gas brine pond site in North Dakota: Ground Water, v. 26, p. 31-38.

North Dakota Oil and Gas Division, 2013, Rules and regulations, accessed March 2013, at https://www.dmr.nd.gov/ oilgas/rules/rulebook.pdf.

Peterman, Z.E., Sims, P.K., Zartman, R.E., and Schulz, K.J., 1985, Middle Proterozoic uplift events in the Dunbar dome of northeastern Wisconsin, USA: Contributions to Mineralogy and Petrology, v. 91, p. 138-150.

Peterman, Z.E., Thamke, J.N., Futa, K., and Oliver, T.A., 2010, Strontium isotope detection of brine contamination in the East Poplar oil field, Montana: U.S. Geological Survey Open-File Report 2010-1326, 20 p. (Also available at http://pubs.usgs.gov/of/2010/1326/.)

Peterman, Z.E., Thamke, J.N., Futa, K., and Preston, T.M., 2012, Strontium isotope systematics of mixing groundwater and oil-field brine at Goose Lake in northeastern Montana, USA: Applied Geochemistry, v. 27, p. 2403-2408.
Powell, W.C., Davis, M.E., Bailey, B.L., and German, E.R., 1973, Water resources monitoring and evaluation-A key to environmental protection in Alabama oil fields: Alabama Geological Survey Information Series 44, 82 p.

Preston, T.M., 2011, Reexamining saline contamination associated with oil and gas development in the Prairie Pothole Region, Sheridan County, MT.: Bozeman, University of Montana, Master's Thesis, 168 p.

Preston, T.M., Chesley-Preston, T.L., and Thamke, J.N., 2013, A GIS-based vulnerability assessment of brine contamination to aquatic resources from oil and gas development in eastern Sheridan County, Montana: Science of the Total Environment, http://dx.doi.org/10.1016/j. scitotenv.2013.09.027.

Preston, T.M., Smith, B.D., Thamke, J.N., and ChesleyPreston, T.L., 2012, Water-quality and geophysical data for three study sites within the Williston Basin and Prairie Pothole Region: U.S. Geological Survey Open-File Report 2012-1149, $17 \mathrm{p}$.

Qing, H., Kent, D., and Bend, S., 2001, Preliminary results of isotopic geochemistry of Ordovician Red River carbonates, subsurface of southeastern Saskatchewan-Implication for process of dolomitization and diagenetic modification of dolomites, in Christopher, J.E., Gilboy, C.F., Haidl, F.M., and Kreis, L.K. eds., Summery of Investigations 2001Volume 1: Regina, Saskatchewan Geological Survey, Miscellaneous Report 2001-4.1, p. 3-9.

Reiten, J.C., and Tischmak, T., 1993, Appraisal of oil field brine contamination in shallow ground water and surface water, eastern Sheridan County, Montana: Billings, Mont., Montana Bureau of Mines and Geology Open-File 260, 296 p., 2 sheets.

Rostron, B.J., and Holmden, C., 2003, Regional variations in oxygen isotopic compositions in the Yeomen and Duperow aquifers, Williston Basin (Canada-USA): Journal of Geochemical Exploration, v. 78-9, p. 337-341.

Rouse, D.R., Nelson, K.J., and Reiten, J.C., 2013, Impacts of oil exploration and production to the Northeast Montana Wetland Management District: Montana Bureau of Mines and Geology Open-File Report 620, 264 p., 1 sheet. (Also available at http://www.mbmg.mtech.edu/mbmgcat/public/ ListCitation.asp?pub_id=31635\&.)

Schwartz, F.W., and Zang, H., 2003, Geology and groundwater, in Schwartz, F.W., and Zang, H., eds., Fundamentals of groundwater: New York, N.Y., John Wiley and Sons, p. 69-106. 
Swanson, G.A., Euliss, N.H. Jr., Hanson, B.A., and Mushet, D.M., 2003, Dynamics of a prairie pothole wetland complex-Implications for wetland management, in Winter, T.C., ed., Hydrological, chemical, and biological characteristics of a Prairie Pothole wetland complex under highly variable climate conditions-The Cottonwood Lake area, east-central North Dakota: U.S. Geological Survey Professional Paper 1675, p. 55-94.
Thamke, J.N., and Craigg, S.D., 1997, Saline-water contamination in Quaternary deposits and the Poplar River, East Poplar oil field, northeastern Montana: U.S. Geological Survey Water-Resources Investigations Report 97-4000, 37 p. (Also available at http://pubs.er.usgs.gov/usgspubs/wri/ wri974000.)

Warren, J.K., 2010, Evaporites through time: Tectonic, climatic and eustatic controls in marine and nonmarine deposits: Earth-Science Reviews, v. 98, p. 217-268. 


\section{Spatial Characterization of Oil and Gas Development and Aquatic Resources in the Williston Basin, United States}

By Brian A. Tangen, Robert A. Gleason, and Tara L. Chesley-Preston

Chapter C of

Brine Contamination to Aquatic Resources from Oil and Gas Development in the Williston Basin, United States

Edited by Robert A. Gleason and Brian A. Tangen

Scientific Investigations Report 2014-5017 
Suggested citation:

Gleason, R.A., and Tangen, B.A., eds., 2014, Brine contamination to aquatic resources from oil and gas development in the Williston Basin, United States: U.S. Geological Survey Scientific Investigations Report 2014-5017, 127 p.,

http://dx.doi.org/10.3133/sir20145017.

Suggested citation for this chapter:

Tangen, B.A., Gleason, R.A., and Chesley-Preston, T.L., 2014, Spatial characterization of oil and gas development and aquatic resources in the Williston Basin, United States, chap. C of Gleason, R.A., and Tangen, B.A., eds., Brine contamination to aquatic resources from oil and gas development in the Williston Basin, United States: U.S. Geological Survey Scientific Investigations Report 2014-5017, p. 63-114, with appendix. 


\section{Contents}

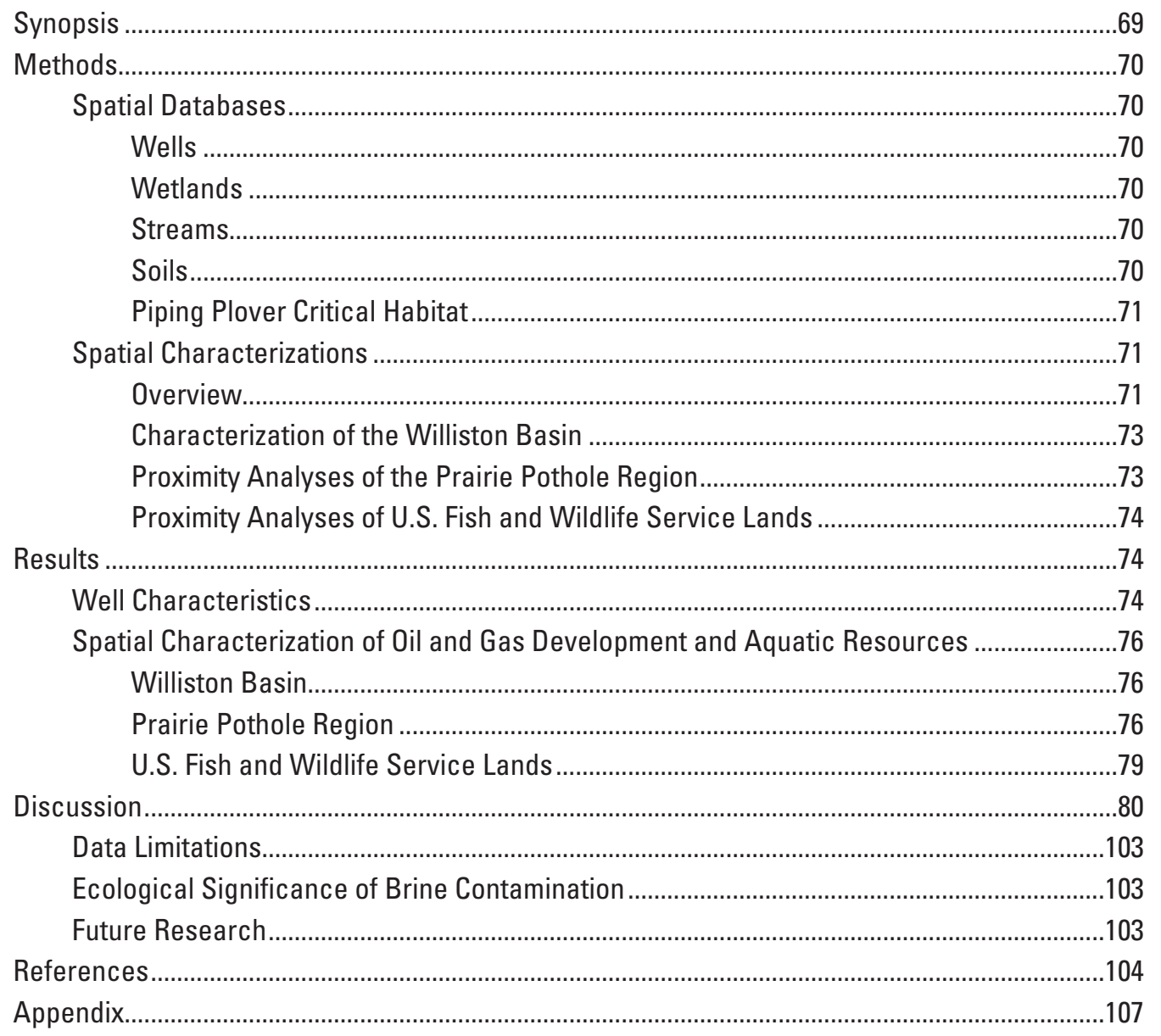




\section{Figures}

C-1. Illustration showing a wetland from the National Wetlands Inventory database where the wetland zones are mapped separately with contiguous polygons.

C-2. Map showing spatial distribution of drilled wells within the Williston Basin and Bakken Formation in the United States.

C-3. Graph showing number of permitted and drilled wells by drilling year; there were 842 wells that did not have a drilling date associated with them

C-4. Graphs showing number of permitted and drilled wells by drilling year for Montana, North Dakota, and South Dakota; there were 842 wells that did not have a drilling date associated with them.

C-5. Graph showing number of producing wells, barrels of oil produced per well, and total barrels of oil produced per year for North Dakota from 1951 to 2010

C-6. Map showing counties within the Williston Basin and Bakken Formation .......................81

C-7. Map showing five counties with the overall greatest number of wells

C-8. Map showing counties with the overall greatest number and density of wells, surface area and density of wetlands, and kilometers and density of streams

C-9. Map showing seven counties with the greatest surface area of wetlands and length of streams within the 0.4-kilometer buffer around all wells in the Prairie Pothole Region of the Williston Basin

C-10. Map showing seven counties with the greatest surface area of wetlands and length of streams within the 0.4-kilometer buffer around all wells in the Prairie Pothole Region of the Williston Basin that were drilled prior to 1980

C-11. Map showing five counties in the Prairie Pothole Region of the study area with the greatest number of wells, surface area of wetlands, and kilometers of streams on, or adjacent to, U.S. Fish and Wildlife Service lands 


\section{Tables}

C-1. Description of spatial databases in the Williston Basin ...................................................71

C-2. Number of wells permitted from January 1, 1901, to February 18,2011 , by well type and State in the Williston Basin ..............................................................................73

C-3. Number of drilled wells by land ownership and State in the Williston Basin ..................76

C-4. Number of wells drilled per State by land cover classifications in the Williston Basin . . .76

C-5. Number of wells drilled per State by land capability classification and farmland classification in the Williston Basin

C-6. Number and percentage of wells drilled in each Soil Survey Geographic database soil drainage classification ............................................................................................ 80

C-7. County area and number and density of wells per county in the Williston Basin ...........82

C-8. Results of the regional evaluation where counties were ranked on the basis of the total number and density of wells, wetlands, and streams in the Williston Basin.

C-9. Surface area and total number of wetlands within each radial buffer around the 10,361 wells in the Prairie Pothole Region portion of the Williston Basin

C-10. Inventory of streams and piping plover critical habitat within each radial buffer around the 10,361 wells in the Prairie Pothole Region portion of the Williston Basin.

C-11. Inventory of wetlands and streams within each radial buffer around the 10,361 wells in the Prairie Pothole Region portion of the study area; buffer inventories were conducted for all well types together

C-12. Inventory of wetlands within each radial buffer round the 5,446 wells in the Prairie Pothole Region portion of the study area that were drilled prior to 1980.

C-13. Inventory of streams and piping plover critical habitat within each radial buffer around the 5,446 wells in the Prairie Pothole Region portion of the study area that were drilled prior to 1980 .

C-14. Inventory of wetlands and streams within each radial buffer around the 5,446 wells in the Prairie Pothole Region portion of the study area that were drilled prior to 1980; buffer analyses were conducted for all well types together.

C-15. Inventory of wells, wetlands, and streams within radial buffers around U.S. Fish and Wildlife Service lands in the Prairie Pothole Region portion of the study area .......99

\section{Appendix table}

C-1. Well classifications for Montana, North Dakota, and South Dakota and the overall well type used for this study. 



\title{
Spatial Characterization of Oil and Gas Development and Aquatic Resources in the Williston Basin, United States
}

\author{
By Brian A. Tangen, ${ }^{1}$ Robert A. Gleason, ${ }^{1}$ and Tara L. Chesley-Preston ${ }^{2}$
}

\section{Synopsis}

The Williston Basin (fig. A-1) has been a leading domestic oil and gas producing region for more than 50 years. A recent U.S. Geological Survey (USGS) assessment (Gaswirth and others, 2013) reported that the Montana and North Dakota part of the Bakken Formation (fig. A-1) and underlying Three Forks Formation (not shown on fig. A-1) contains a vast hydrocarbon reserve that ranks among the largest in the world. The large amount of recoverable oil and gas, combined with advancements in recovery technologies and high oil prices, have led to a modern oil boom in the region. A large volume of produced waters, or brines, can be generated during recovery operations, with some estimates exceeding 10 barrels of brine produced per barrel of oil extracted (Wanty, 1997). Brines associated with oil and gas extraction in the Williston Basin differ greatly from natural surface water and the shallow groundwater with regards to salinity and ionic composition, and these brines have total dissolved solids concentrations that are among the highest in the Nation (see chapters A and $\mathrm{B}$ of this report). Concerns over past methods of storage and disposal for these brines, coupled with the huge increase in oilfield activities and higher incidences of accidental discharges, have led to an elevated awareness of the potential environmental effects associated with oil and gas recovery. Of special concern in the region is the addition of brines to wetlands and streams that provide critical habitat for waterfowl and other wildlife, as well as water for agricultural irrigation and livestock.

Montana and the Dakotas have a long history of oil and gas production and a strong tradition of conservation-focused land management, much of which has focused on the region's ecologically vital prairie pothole wetlands. However, very little research has examined the potential effects of oil and gas production on aquatic resources in the region, and there are no studies that have characterized the region in terms of the distribution of oil wells and aquatic ecosystems. The objectives of this study were to gather spatial databases to support a regional characterization of oil and gas wells, wetlands, and

\footnotetext{
${ }^{1}$ U.S. Geological Survey

${ }^{2}$ Montana State University
}

streams in the Williston Basin and to identify areas with a greater likelihood of containing brine-contaminated aquatic resources on the basis of the number and distribution of wells, wetlands, and streams.

A key component of any large, regional assessment is the ability to describe an area using spatial databases and a geographic information system (GIS). For this study, numerous spatial databases were gathered that detail oil- and gasrelated wells (referred to simply as wells hereafter), wetlands, streams, critical habitats, land ownership, and soils. These spatial layers were used to describe temporal drilling trends and the spatial distribution and general characteristics (for example, well type and land ownership) of wells within the Williston Basin. Further, areas with a greater likelihood of containing brine-contaminated aquatic resources were distinguished by identifying counties with the greatest numbers and densities of wells, wetlands, and streams.

Over 30,000 wells were permitted and drilled in the study area (the U.S. part of the Williston Basin and Bakken Formation) from approximately 1901 to 2011. A majority of these wells were drilled after 1950 and located primarily on private lands in northeastern Montana and western North Dakota. The seven counties identified as having the greatest amount and densities of wells and aquatic resources include McKenzie (N. Dak.), Phillips (Mont.), Valley (Mont.), Williams (N. Dak.), Dunn (N. Dak.), Mountrail (N. Dak.), and Bowman (N. Dak.). Within the Prairie Pothole Region (PPR) of the study area (fig. A-1), roughly 290,000 wetlands covering approximately 1,800 square kilometers $\left(\mathrm{km}^{2}\right), 7,000$ kilometers $(\mathrm{km})$ of streams, and $80 \mathrm{~km}^{2}$ of critical habitat to the threatened piping plover (Charadrius melodus) were within $1.6 \mathrm{~km}$ of wells. Based on these estimates, approximately one-third of all wetlands within the PPR in the United States part of the study area were within $1.6 \mathrm{~km}$ of a well, a distance that brine could migrate over time in glacial outwash sediments. The seven counties with the greatest amounts of wetlands and streams within $0.4 \mathrm{~km}$ of wells (distance brine has been shown to migrate over time in glacial till sediments; see Chapter B) included Burke (N. Dak.), Bottineau (N. Dak.), Sheridan (Mont.), Divide (N. Dak.), Mountrail (N. Dak.), Phillips (Mont.), and Renville (N. Dak.). Greater than 1,200 wells, more than $80,000 \mathrm{~km}^{2}$ of wetlands, and nearly $3,000 \mathrm{~km}$ of streams also were identified on or adjacent to (within $1.6 \mathrm{~km}$ ) 
U.S. Fish and Wildlife Service (USFWS) conservation lands (national wildlife refuges [NWR] and waterfowl production areas [WPA]) in the PPR part of the study area. The five counties with the greatest amount of wells and aquatic resources on or near USFWS lands included Bottineau (N. Dak.), Sheridan (Mont.), Renville (N. Dak.), Burke (N. Dak.), and Divide (N Dak.). Further, it was concluded that a great number of private lands protected by USFWS conservation easements in the PPR were located near wells.

\section{Methods}

\section{Spatial Databases}

Various spatial databases were gathered relating to oil and gas development (for example, well location, well type, drilling date, hydrocarbon-producing formations), aquatic resources (wetlands, streams), soils, land cover, ownership, and riparian habitats critical to the threatened piping plover. The majority of these data were obtained from government agency Web pages and data outlets or through direct contact with agency personnel. General database descriptions and data sources are presented in table $\mathrm{C}-1$ and a regional characterization of the wells (for example, number of wells by well type, ownership) is presented in the results section. Additional information is provided in the following paragraphs where further descriptions are warranted.

\section{Wells}

Data regarding oil and gas wells were acquired (19012011) from the individual State (Montana, North Dakota, South Dakota) oil and gas divisions. There is no standard method of data collection and storage between the States; therefore, a crosswalk between the databases was required (see appendix $\mathrm{C}-1$ for crosswalk details). This crosswalk facilitated the creation of a single database containing consistent information regarding all of the permitted wells. Of particular interest was the development of regionally consistent terminology for the well types, which were condensed into the following categories: (1) oil, (2) dry hole, (3) gas, (4) injection, (5) other, and (6) never drilled. Wells categorized as "other" included those classified as confidential, monitor/observation, stratigraphic test, water, or unknown. Although a well is permitted for drilling, it does not necessarily mean that the well was drilled. Many drilling permits are simply cancelled or have expired, yet they still exist within the State records and databases; these sites were categorized as "never drilled" and excluded from all analyses.

\section{Wetlands}

Two distinct wetland databases were used for various analyses; a brief description follows to clarify the differences between them. The standard USFWS National Wetlands Inventory (NWI) database ( U.S. Fish and Wildlife Service, 2010) was relied on for broad comparisons across the entire study area. In addition to the standard NWI database, a modified NWI database covering a large part of the PPR also was obtained from the USFWS Habitat and Population Evaluation Team (HAPET), located in Bismarck, N. Dak. Daniels County, Mont., is the western extent of this database. With the standard NWI data, it is not uncommon for the various zones (for example, temporary, seasonal) of a single wetland to be mapped separately; thus, a distinct wetland may consist of two or more polygons with unique classifications. For the modified NWI database provided by the HAPET, contiguous polygons representing a wetland were collapsed into a single polygon and classified according to the most permanent classification of the individual polygons. Figure $\mathrm{C}-1$ depicts a palustrine emergent wetland from the standard NWI where temporary (area designated PEMA) and seasonal (area designated PEMC) zones were delineated and mapped with contiguous polygons. In the HAPET database, these two polygons would be combined and categorized as PEMC. This modified database allowed for inclusion of the number and the entire surface area of wetlands in various analyses and data summaries because each wetland was represented by a single polygon and could not be counted multiple times.

\section{Streams}

Stream data were obtained from the USGS, medium resolution National Hydrography Dataset (NHD) (U.S. Geological Survey, 2009). Although the NHD contains extensive spatial data representing the surface-water features within the United States, the primary focal areas of this study were flow-line features such as streams and rivers; thus, only features coded as 'stream/river' (feature codes are 46000, 46003, 46006, or 46007) were used for analyses.

\section{Soils}

Primary factors regulating hydraulic conductivity and the migration of brines through soils include precipitation and soil permeability. Therefore, estimates of soil permeability can be useful when assessing the potential for subsurface brine migration from a given site. There are numerous geologic databases (Soller and Packard, 1998; Stoeser and others, 2007) that can be used to estimate this variable, but they have a very coarse spatial resolution and reference the deeper geologic layers. The U.S. Department of Agriculture (2010), Natural Resources Conservation Service, Soil Survey Geographic (SSURGO) database characterizes the surface soils at a relatively fine scale $(1: 24,000)$ and includes rough surrogates for permeability such as drainage class (for example, well drained, poorly drained) and soil texture (for example, percent clay or sand). The drainage class identifies the natural drainage conditions of the soil and refers to the frequency and duration of wet 
Table C-1. Description of spatial databases in the Williston Basin.

\begin{tabular}{|c|c|}
\hline Database & Source(s)/description \\
\hline \multirow[t]{3}{*}{ Wells } & $\begin{array}{l}\text { Information relating to well type, permit date, location, and status was obtained from the following State } \\
\text { regulating agencies: }\end{array}$ \\
\hline & $\begin{array}{l}\text { 2. North Dakota Industrial Commission, Department of Mineral Resources, Oil and Gas Division (web site } \\
\text { accessed February 18, 2011, at https://www.dmr.nd.gov/oilgas/). }\end{array}$ \\
\hline & - Well data were obtained for the time period January 1, 1901, to February 18, 2011. \\
\hline Wetlands & $\begin{array}{l}\text { Wetland data were obtained from the U.S. Fish and Wildlife Service (USFWS), National Wetlands Inventory } \\
\text { (NWI; web site accessed May 1, 2010, at } h t t p: / / w w w . f w s . g o v / w e t l a n d s / \text { ). A modified NWI database was } \\
\text { obtained from the USFWS, Habitat and Population Evaluation Team (HAPET) located in Bismarck, North } \\
\text { Dakota (web site accessed July 1, 2013, at } h t t p: / / w w w . p p j v . o r g / h a p e t / h a p e t \text { bismark.htm). The HAPET } \\
\text { database (version January 17, 2001) covers only the majority of Prairie Pothole Region of the study area } \\
\text { (fig. A-1); Daniels County, Montana, is the westernmost county included. }\end{array}$ \\
\hline Land cover & $\begin{array}{l}\text { Land cover data were obtained from the USGS National Land Cover Database } 2006 \text { (NLCD; web site ac- } \\
\text { cessed July 1, 2013, at http://landcover.usgs.gov/index.php). }\end{array}$ \\
\hline Land ownership & $\begin{array}{l}\text { Land ownership information was obtained from the USGS Protected Areas Database, version } 1.1 \text { (web site } \\
\text { accessed July 1, 2013, at http://gapanalysis.usgs.gov/padus/data/additional-data/). }\end{array}$ \\
\hline $\begin{array}{l}\text { Regional and geologic } \\
\text { boundaries }\end{array}$ & $\begin{array}{l}\text { Boundaries for the Williston Basin and Bakken Formation were obtained from the USGS, National As- } \\
\text { sessment of Oil and Gas Project (web site accessed July 1, 2013, at http://energy.usgs.gov/OilGas/ } \\
\text { AssessmentsData/NationalOilGasAssessment.aspx). The Prairie Pothole Region boundary was provided } \\
\text { by the USGS, Northern Prairie Wildlife Research Center (web site accessed July 1, 2013, at http://www. } \\
\text { npwrc.usgs.gov/). }\end{array}$ \\
\hline
\end{tabular}

periods. A drainage class was assigned to each well based on the dominant soil associated with it.

\section{Piping Plover Critical Habitat}

The NWI and NHD provide general habitat (wetlands, streams) information that can be related to taxa of interest, such as waterfowl, but these data do not provide speciesspecific habitat information. Alternatively, spatial data were obtained that identified critical riparian habitats of the threatened piping plover, which is considered a management priority for the USFWS. These data were included in various analyses to evaluate the proximity of critical habitats to wells and provide an example of how habitat data can be used to supplement the well, NWI, and NHD information.

\section{Spatial Characterizations}

\section{Overview}

Various spatial characterizations and analyses were performed to identify areas with the greatest likelihood of containing brine-contaminated aquatic resources based primarily on locations of wells, wetlands, and streams. A generalized regional assessment was performed for the area defined by the boundaries of the Williston Basin and Bakken Formation within the United States (hereafter referred to as the study 


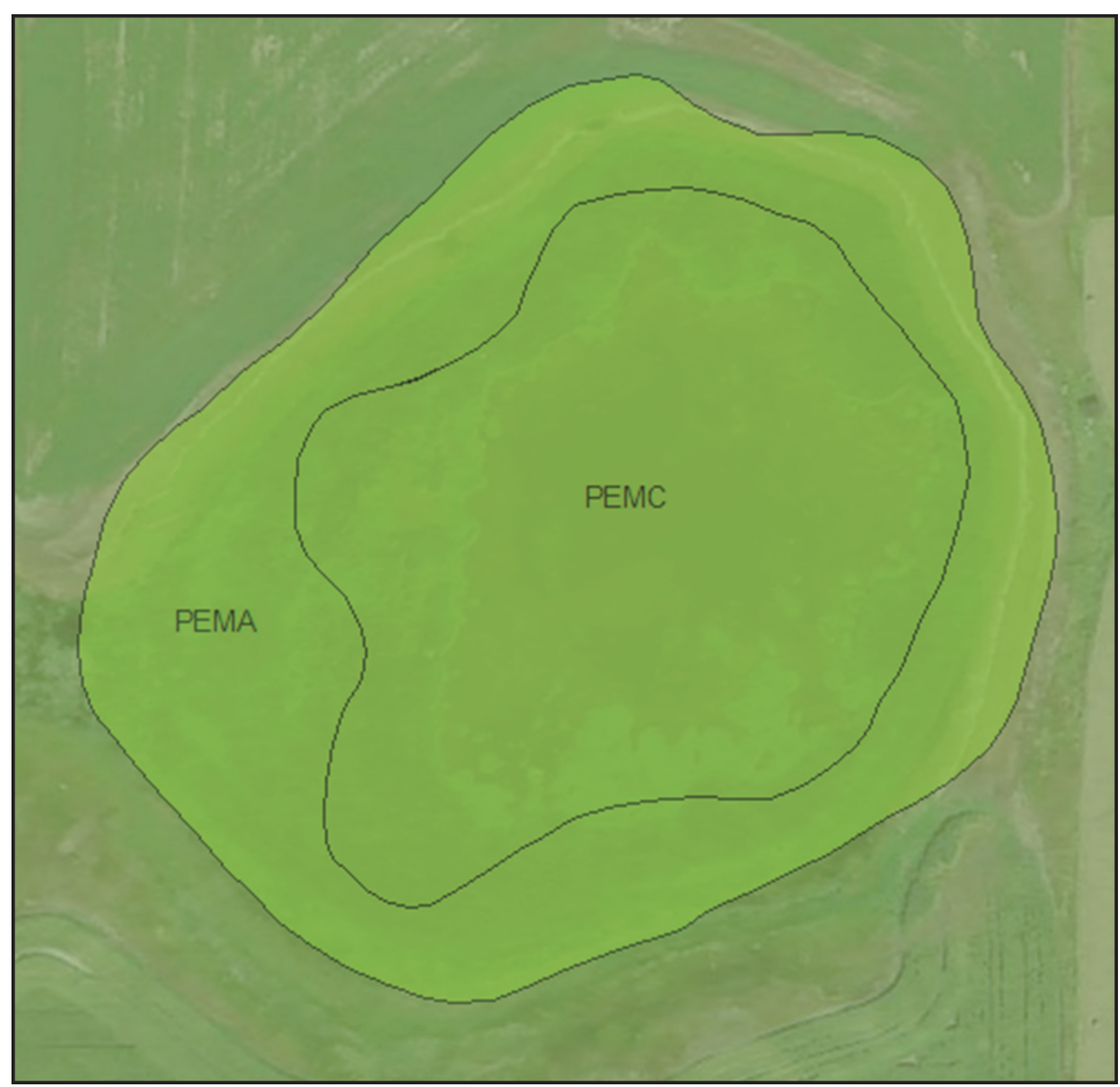

EXPLANATION

PEMA Temporary zone

PEMC Seasonal zone

Figure C-1. A wetland from the National Wetlands Inventory database where the wetland zones are mapped separately with contiguous polygons.

area; fig. A-1) by identifying counties with the greatest total number and density of wells and aquatic resources. This type of spatial examination, however, presents a form of the modifiable area unit problem (Openshaw, 1984) in that it does not account for the distribution of wells and aquatic resources within the area of interest. Therefore, a more focused proximity analysis was performed for the PPR part of the study area (the part where the PPR overlays the study area; fig. A-1), which identified counties with the greatest amount of aquatic resources proximate to wells. A similar proximity analysis also was done to identify counties with the greatest number USFWS resources near wells.

Policies were enacted during the 1970 s to regulate the usage of unlined, earthen reserve pits for produced waters. These regulations required the lining of pits to reduce the likelihood of leaching saline contamination into the shallow groundwater system. Comprehensive information or spatial data pertaining to the location of reserve or evaporation pits were unavailable. However, assumptions were made that wells activated prior to approximately 1980 were more likely to 
be associated with unlined pits, and these sites would have a higher likelihood of brines leaching into soils and the shallow groundwater system and migrating to wetlands and streams. Therefore, the proximity analyses also were performed on only those wells drilled prior to 1980 to identify counties with the greatest amount of aquatic resources proximate to wells likely associated with the older, unlined pits.

These approaches for identifying areas with a greater likelihood of containing brine-contaminated aquatic resources are based on two overall assumptions. First, areas with the greatest total number and densities of wells, wetlands, and streams have a higher probability that oil and gas production activities would affect aquatic resources. Second, it is expected that the highest probability of brine contamination would exist in areas with the greatest number of wetlands and streams proximate to wells. These theories rely on the random occurrence of potentially harmful activities or events (for example, brine spills, leaching from reserve pits) across the region. Realistically, however, older wells likely pose a greater threat because they often are associated with unlined reserve or evaporation pits, produce a greater proportion of brine to oil and gas (Veil and others, 2004), and are associated with aging infrastructure that is more likely to fail.

Oil and gas production wells are most often associated with brine contamination; however, all related well types were considered for assessments because most drilling activities result in wells that pass through geologic formations containing saline waters and require a reserve or evaporation pit. Therefore, there is some potential risk associated with leakage, seepage, or spills from well holes, leaching from reserve or evaporation pits, pipelines, storage-tank batteries, and overthe-road transportation. As an example, wells used to obtain water for drilling purposes often target deep saline reserves. Further, the classification of a well can change over time. For instance, it is uncommon to drill a well specifically for disposal; rather, expired oil and gas wells are often reopened and used as injection wells. Thus, current injection wells likely were production wells in the past. For all analyses described below, the number of wells included all types that were drilled (table C-2), wetlands included those classified as temporary, seasonal, semipermanent, lake, or riverine, and streams included segments classified as stream/river. For the characterization of the Williston Basin, wetland surface areas were calculated from the standard NWI, while the proximity analyses were performed using the modified NWI database from the HAPET; stream lengths for all analyses were obtained from the NHD.

\section{Characterization of the Williston Basin}

A general spatial characterization and evaluation were performed on the study area with the goal of identifying counties with the greatest likelihood of containing brine-contaminated aquatic resources based on the total number and density of wells, wetlands, and streams. Density is defined as the number of wells, square kilometers of wetlands, or kilometers
Table C-2. Number of wells permitted from January 1, 1901, to February 18, 2011, by well type and State in the Williston Basin.

\begin{tabular}{|c|c|c|c|c|}
\hline Well type & Montana & $\begin{array}{c}\text { North } \\
\text { Dakota }\end{array}$ & $\begin{array}{c}\text { South } \\
\text { Dakota }\end{array}$ & Total \\
\hline Oil & 3,627 & 9,243 & 309 & 13,179 \\
\hline Dry hole & 3,234 & 5,813 & 472 & 9,519 \\
\hline Gas & 4,620 & 327 & 170 & 5,117 \\
\hline Never drilled & 1,053 & 2,564 & 63 & 3,680 \\
\hline Injection & 768 & 1,259 & 90 & 2,117 \\
\hline Other $^{1}$ & 98 & 1,276 & -- & 1,374 \\
\hline Total & 13,400 & 20,482 & 1,104 & 34,986 \\
\hline
\end{tabular}

${ }^{1}$ Includes wells classified as confidential, monitor/observation, stratigraphic test, water, or unknown.

of streams divided by the square kilometers of the county that falls within the study area. Counties were ranked (1-68, where 1 is the highest rank) by total number and density of wells, surface area and density of wetlands, and length and density of streams; overall ranks for total number and density were calculated as the mean of the three individual ranks (wells, wetlands, and streams). For this overall evaluation, counties were assessed on the basis of the mean ranks; thus, wells, wetlands, and streams were weighted equally.

\section{Proximity Analyses of the Prairie Pothole Region}

The extent was estimated for the PPR part of the study area that aquatic habitats were proximate to wells in order to identify counties with the greatest likelihood of containing brine-contaminated aquatic resources. This proximity analysis accounts for the spatial distribution of wells and aquatic resources and includes a distance measure to help identify areas with the greatest potential for containing brine-contaminated aquatic resources. This evaluation was limited to the PPR because of the ecological importance of the region's aquatic resources, most notably the pothole wetlands that characterize the area. In addition, the modified NWI database provided by the HAPET covered only a majority of the PPR and did not extend to the remainder of the study area. The standard NWI data are not conducive to this type of analysis because wetlands consisting of multiple polygons are difficult to classify and could be counted more than once; additionally, it is difficult to determine the entire surface area of individual multipolygon wetlands over a large spatial extent.

To evaluate the spatial relations between wells and aquatic resources, a GIS (ArcGIS 10, service pack 1) was used to calculate radial buffers of $0.4 \mathrm{~km}, 0.8 \mathrm{~km}$, and 1.6 $\mathrm{km}$ around each well located within the PPR part of the study area. These buffers were meant to represent distances that brine could migrate over time from a point source, such as an unlined reserve pit, to wetlands and streams. These buffer distances were selected on the basis of expert opinion supported by geophysical field surveys and water-quality monitoring 
aimed at evaluating subsurface brine migration within the Williston Basin (see chapter B of this report).

For proximity analyses, the number and surface area of wetlands and length of streams within the three buffers were calculated and summed by county. The entire surface area of the wetland was considered, not just the part of the wetland that fell within the buffer; however, stream length was calculated as the segment that fell within the buffer. Additionally, the area within the buffers designated as piping plover critical habitat was calculated using the spatial database provided by the USFWS. Buffers were merged when they overlapped so as not to double-count wetlands, stream segments, or parcels of critical habitat.

\section{Proximity Analyses of U.S. Fish and Wildlife Service Lands}

A more focused proximity analysis was performed to identify counties in the PPR part of the study area with the greatest number of wells and aquatic resources located on or near USFWS managed lands, specifically NWRs and WPAs. Similar to the overall PPR analysis, radial buffers of $0.4 \mathrm{~km}$, $0.8 \mathrm{~km}$, and $1.6 \mathrm{~km}$ were calculated around each USFWS parcel (instead of buffers around wells) and the wells, wetlands, and streams within each buffer (including within the parcel) were inventoried. The number of wells, surface area of wetlands, and length of streams within each buffer were summed by county, and each county was ranked based on the well, wetland, and stream summaries. These three individual county ranks were averaged by buffer distance $(0.4,0.8,1.6 \mathrm{~km})$ and counties were assigned overall rank by calculating an average across the three buffers. Only counties with at least 10 wells within each buffer were considered for the overall comparison so that counties that ranked highly for wetlands and streams, but contained only a few wells, would not unduly influence interpretation of the analysis.

In addition to NWRs and WPAs owned in fee title, the USFWS also administers nearly 30,000 conservation easements throughout the Dakotas and Montana. Wetland and grassland easements are legal agreements between private landowners and the U.S. Government where, in exchange for financial compensation, landowners agree to a number of contractual stipulations designed to maintain wetland and grassland habitats. Regardless of the type of easement, landowners continue to own and manage the land; however, in the case of wetland easements, they agree to not drain, fill, level, or burn, and in the case of grassland easements, they consent to not convert the grassland to other uses. Although USFWS conservation easements do not have legal jurisdiction relative to effects of brine contamination from oil and gas development (easements typically specify physical disturbances such as draining, filling, burning), these tracts of land still represent at-risk areas of existing habitat that are important to USFWS trust species, especially migratory birds. The number of USFWS easement land parcels (summarized by contract, circa 2010) intersected by the three buffers $(0.4,0.8$, and $1.6 \mathrm{~km})$ around wells was identified to determine the extent at which these lands are proximate to wells. This USFWS proximity analysis differs from the one previously described because of data limitations.

\section{Results}

\section{Well Characteristics}

The regional analyses identified 34,986 oil- and gasrelated wells (table $\mathrm{C}-2$ ) in the study area that were permitted from January 1901 to February 2011, of which 31,306 were drilled. Of the well types considered, approximately 38 percent were classified as oil, followed by dry hole (27 percent), gas (15 percent), injection ( 6 percent), and other ( 4 percent); the 10 percent classified as never drilled were excluded from all analyses. Based on the overall spatial distribution of the drilled wells, it is evident that the majority of the activity has taken place in western North Dakota and northeastern Montana (fig C-2). North Dakota contained the greatest number of wells, followed by Montana and South Dakota (table C-2). Nearly 25,000 of the wells, or 80 percent, were located on private lands, with lower proportions on U.S. Government and State/local government, and Native American lands (table C-3). A majority (89 percent) of wells were located on lands classified by the USGS National Land Cover Database as herbaceous grasslands (15,930 wells) and cultivated croplands (11,766 wells) (table C-4). On the basis of the SSURGO land capability and farmland classifications, a greater number of wells were sited on nonprime farmland than other classifications (table $\mathrm{C}-5$ ).

A majority of the wells within the study area were permitted after 1950, with noticeable peaks in drilling activity around 1960, 1980, and the present (circa 2011; fig. C-3); these trends are consistent when examined at the State level (fig. C-4). The likelihood of aquatic resources being contaminated by brines is not solely related to the number of wells drilled near wetlands and streams. The amount of brine produced per barrel of oil typically increases as more barrels of oil and gas are extracted (Veil and others, 2004); thus, actual oil and gas production is the key. Data from the North Dakota Industrial Commission, Department of Mineral Resources, Oil and Gas Division (2011) show that trends in oil production closely follow trends in well drilling (fig. C-5), suggesting that well permitting and drilling activity are good surrogates for predicting trends in production and evaluating potential for brine contamination.

A drainage class was assigned to each well based on the dominant soil; however, drainage class was only determined for 30,894 out of the 31,306 permitted and drilled wells because of data limitations. On the basis of this classification, approximately 95 percent of wells were located on well drained or excessively drained soils; the remaining 5 percent of wells were situated on poorly drained soils (table $\mathrm{C}-6$ ). 


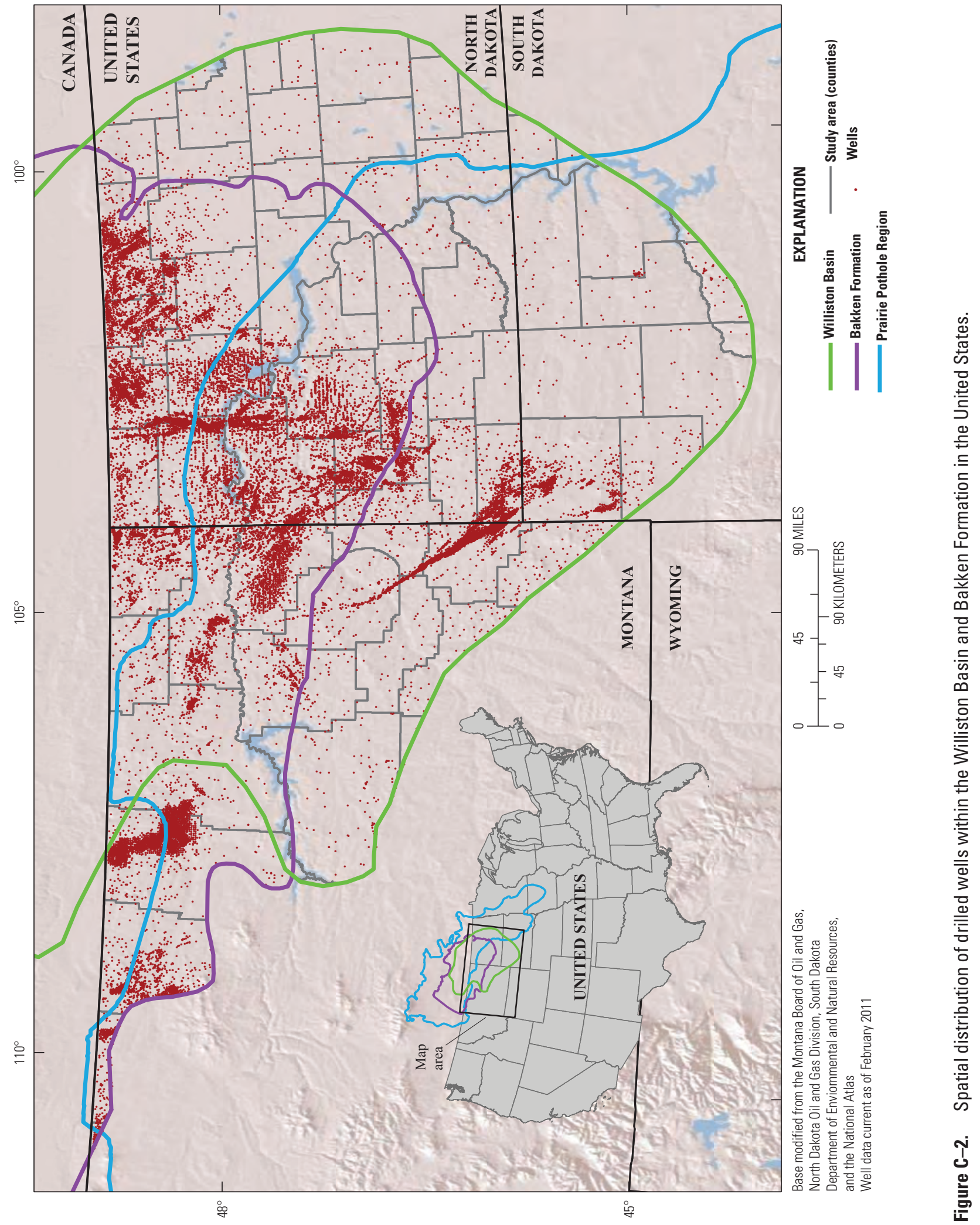


Table C-3. Number of drilled wells by land ownership and State in the Williston Basin.

\begin{tabular}{lrrrr}
\hline \multicolumn{1}{c}{ Ownership } & Montana & $\begin{array}{c}\text { North } \\
\text { Dakota }\end{array}$ & $\begin{array}{c}\text { South } \\
\text { Dakota }\end{array}$ & Total \\
\hline Private & 9,231 & 14,883 & 748 & 24,862 \\
U.S. Government & 1,992 & 1,786 & 59 & 3,837 \\
State/local & 736 & 543 & 154 & 1,433 \\
Native American & 360 & 699 & 78 & 1,137 \\
Unknown & 28 & 7 & 2 & 37 \\
Total & $\mathbf{1 2 , 3 4 7}$ & $\mathbf{1 7 , 9 1 8}$ & $\mathbf{1 , 0 4 1}$ & $\mathbf{3 1 , 3 0 6}$ \\
\hline
\end{tabular}

Table C-4. Number of wells drilled per State by land cover classifications in the Williston Basin.

$[--$, no record $]$

\begin{tabular}{lrrrr}
\hline \multicolumn{1}{c}{ Land cover } & Montana & $\begin{array}{c}\text { North } \\
\text { Dakota }\end{array}$ & $\begin{array}{c}\text { South } \\
\text { Dakota }\end{array}$ & Total \\
\hline Grassland/herbaceous & 7,539 & 7,527 & 864 & 15,930 \\
Cultivated crops & 3,264 & 8,441 & 61 & 11,766 \\
Shrub/scrub & 995 & 290 & 46 & 1,331 \\
Pasture/hay & 59 & 710 & 44 & 813 \\
Developed, open space & 210 & 406 & 12 & 628 \\
Barren land & & & & \\
$\quad$ (rock/sand/clay) & 108 & 145 & 2 & 255 \\
Emergent herbaceous & & & & \\
$\quad$ wetlands & 41 & 195 & 3 & 239 \\
Developed, low intensity & 37 & 87 & -- & 124 \\
Woody wetlands & 51 & 35 & 3 & 89 \\
Deciduous forest & 3 & 51 & -- & 54 \\
Evergreen forest & 24 & 5 & 5 & 34 \\
Open water & 9 & 17 & 1 & 27 \\
Developed, medium & & & & \\
$\quad$ intensity & 7 & 1 & -- & 8 \\
Mixed forest & -- & 8 & -- & 8 \\
Total & $\mathbf{1 2 , 3 4 7}$ & $\mathbf{1 7 , 9 1 8}$ & $\mathbf{1 , 0 4 1}$ & $\mathbf{3 1 , 3 0 6}$ \\
\hline
\end{tabular}

\section{Spatial Characterization of Oil and Gas Development and Aquatic Resources}

\section{Williston Basin}

Mean densities for the 68 counties in the study area (fig. C-6) with at least one well, wetland, and stream segment were 0.11 wells $/ \mathrm{km}^{2}$ (range less than $0.01-0.65$ ), $0.06 \mathrm{~km}^{2}$ of wetlands $/ \mathrm{km}^{2}$ (range less than $0.01-0.33$ ), and $0.67 \mathrm{~km}$ of streams $/ \mathrm{km}^{2}$ (range $0.13-1.29$ ). The total number and density of wells for each county are presented in table $\mathrm{C}-7$; data are presented for all drilled wells (all years) and for only the 13,349 wells drilled prior to 1980 . Figure $\mathrm{C}-7$ depicts the five counties with the greatest number of wells drilled during all years and those drilled prior to 1980. The five counties with the highest number of wells (all years) were: (1) McKenzie, N. Dak., (2) Fallon, Mont., (3) Phillips, Mont., (4) Bottineau, N. Dak., and (5) Williams, N. Dak. The five counties with the highest number of wells drilled prior to 1980 were: (1) Bottineau, N. Dak., (2) McKenzie, N. Dak., (3) Phillips, Mont., (4) Fallon, Mont., and (5) Williams, N. Dak. Table C-8 lists the area, mean and individual ranks, number and density of wells, surface area and density of wetlands, and length and density of streams for each county within the study area. The seven counties with the greatest likelihood of containing brine-contaminated aquatic resources, based on the mean ranks (that is, greatest total number or densities of wells and aquatic resources), are depicted in figure $\mathrm{C}-8$. McKenzie County (N. Dak.) was ranked highest on the basis of total numbers and densities; the six other highly ranked counties included Phillips (Mont.), Valley (Mont.), Williams (N. Dak.), Dunn (N. Dak.), Mountrail (N. Dak.), and Bowman (N. Dak.) (fig. C-8). The seven counties represent the five counties with the highest mean ranks based on density and total number; McKenzie, Williams, and Dunn Counties ranked in the top five for both categories.

\section{Prairie Pothole Region}

A general inventory of the approximately $78,200 \mathrm{~km}^{2}$ of the PPR part of the study area identified 10,361 wells, 860,132 wetlands, $24,848 \mathrm{~km}$ of streams, and $436 \mathrm{~km}^{2}$ of piping plover critical habitat. The surface area and total number of wetlands, length of streams, and area of critical habitat within each of the three radial buffers around wells are presented in tables C-9 (wetlands) and C-10 (streams, habitat). The buffer inventories were performed on all well types together and individually to allow for specific investigations or comparisons; hereafter all discussions will focus solely on analyses performed on all well types. Overall, of the 860,132 wetlands identified in the PPR, approximately 7 percent, 17 percent, and 34 percent were within the $0.4-\mathrm{km}, 0.8-\mathrm{km}$, and $1.6-\mathrm{km}$ buffers, respectively. Specifically, there were 62,718 total wetlands covering $501 \mathrm{~km}^{2}, 1,380 \mathrm{~km}$ of streams, and $5 \mathrm{~km}^{2}$ of critical habitat proximate (within $0.4-\mathrm{km}$ buffer) to wells in the PPR. The intermediate $(0.8-\mathrm{km})$ buffer included 146,978 total wetlands covering $975 \mathrm{~km}^{2}, 3,291 \mathrm{~km}$ of streams, and $22 \mathrm{~km}^{2}$ of critical habitat. Expanding the buffer area to $1.6 \mathrm{~km}$ resulted in a relatively large increase in all variables with estimates of 292,745 total wetlands covering $1,780 \mathrm{~km}^{2}, 7,147 \mathrm{~km}$ of streams, and $79 \mathrm{~km}^{2}$ of piping plover critical habitat within this largest buffer.

Each county in the PPR was ranked on the basis of the surface area of wetlands and length of streams within the 0.4-km buffers around wells to identify areas where these 
Table C-5. Number of wells drilled per State by land capability classification and farmland classification in the Williston Basin.

$[--$, no record $]$

\begin{tabular}{|c|c|c|c|c|}
\hline Land capability classification, nonirrigated soils & Montana & $\begin{array}{l}\text { North } \\
\text { Dakota }\end{array}$ & $\begin{array}{l}\text { South } \\
\text { Dakota }\end{array}$ & Total \\
\hline None & 135 & 22 & 3 & 160 \\
\hline $\begin{array}{l}\text { Soils have moderate limitations that reduce the choice of plants or require modera } \\
\text { conservation practices }\end{array}$ & -- & 7,963 & 80 & 8,043 \\
\hline $\begin{array}{l}\text { Soils have severe limitations that reduce the choice of plants or require special co } \\
\text { vation practices, or both }\end{array}$ & 4,689 & 2,387 & 82 & 7,158 \\
\hline $\begin{array}{l}\text { Soils have very severe limitations that restrict the choice of plants or require very } \\
\text { ful management, or both }\end{array}$ & 3,047 & 2,265 & 248 & 5,560 \\
\hline $\begin{array}{l}\text { Soils have little or no hazard of erosion but have other limitations, impractical to } \\
\text { remove, that limit their use mainly to pasture, range, forestland, or wildlife fooc } \\
\text { cover }\end{array}$ & 19 & 8 & 2 & 29 \\
\hline $\begin{array}{l}\text { Soils have severe limitations that make them generally unsuited to cultivation and } \\
\text { limit their use mainly to pasture, range, forestland, or wildlife food and cover }\end{array}$ & 3,052 & 2,774 & 444 & 6,270 \\
\hline $\begin{array}{l}\text { soils have very severe limitations that make them unsuited to cultivation and that } \\
\text { restrict their use mainly to grazing, forestland, or wildlife }\end{array}$ & 1,397 & 2,045 & 173 & 3,615 \\
\hline $\begin{array}{l}\text { Soils and miscellaneous areas have limitations that preclude their use for commer } \\
\text { plant production and limit their use to recreation, wildlife, or water supply or fo } \\
\text { esthetic purposes }\end{array}$ & 8 & 454 & 9 & 471 \\
\hline Total & 12,347 & 17,918 & 1,041 & 31,306 \\
\hline Farmland classification & & & & \\
\hline None & 1,624 & -- & -- & 1,624 \\
\hline All areas are prime farmland & -- & 2,981 & 2 & 2,983 \\
\hline Farmland of local importance & -- & 7 & -- & 7 \\
\hline Farmland of statewide importance & 2,156 & 4,079 & 87 & 6,322 \\
\hline Not prime farmland & 7,888 & 10,060 & 920 & 18,868 \\
\hline Prime farmland if drained & -- & 720 & -- & 720 \\
\hline Prime farmland if irrigated ${ }^{1}$ & 679 & 71 & 32 & 782 \\
\hline Total & 12,347 & 17,918 & 1,041 & 31,306 \\
\hline
\end{tabular}

${ }^{1}$ Includes soils classified as (1) prime farmland if irrigated and (2) prime farmland if irrigated and the product of I (soil erodibility) $\mathrm{x} C$ (climate factor) does not exceed 60 .

aquatic resources have the greatest potential to be affected by oil and gas production activities. The seven counties with the greatest surface area of wetlands or kilometers of streams proximate to wells were: Burke (N. Dak.), Bottineau (N. Dak.), Sheridan (Mont.), Divide (N. Dak.), Mountrail (N. Dak.), Phillips (Mont.), and Renville (N. Dak.) (fig. C-9). County area, surface area and number of wetlands, and stream length are presented by county for each of the three buffers in table $\mathrm{C}-11$. The seven counties represent the five counties with the highest mean ranks based on wetlands and streams; Bottineau, Burke, and Sheridan Counties ranked in the top five for both variables.

Of the 13,349 wells drilled prior to 1980 in the study area, 5,446 were located within the PPR part of the study area. On the basis of the buffer inventories performed on these PPR wells, it was determined that approximately 4 percent, 11 percent, and 24 percent of the 860,132 PPR wetlands fell within the $0.4-\mathrm{km}, 0.8-\mathrm{km}$, and $1.6-\mathrm{km}$ buffers, respectively. There were $285 \mathrm{~km}^{2}$ of wetlands (37,583 wetlands), $736 \mathrm{~km}$ of streams, and $2 \mathrm{~km}^{2}$ of piping plover critical habitat proximate (within the $0.4-\mathrm{km}$ buffer) to all wells drilled prior to 1980 (tables C-12, C-13). The intermediate $(0.8 \mathrm{~km})$ buffer included $605 \mathrm{~km}^{2}$ of wetlands (92,910 wetlands), 2,091 km of streams, and $10 \mathrm{~km}^{2}$ of critical habitat, while the largest buffer $(1.6 \mathrm{~km})$ encompassed 1,288 $\mathrm{km}^{2}$ of wetlands $(206,805$ wetlands), $5,002 \mathrm{~km}$ of streams, and $38 \mathrm{~km}^{2}$ of critical habitat (tables C-12, C-13). For all wells drilled prior to 1980, the surface area and total number of wetlands, length of streams, and area of piping plover critical habitat within each of the three buffers are presented in tables C-12 (wetlands) and $\mathrm{C}-13$ (streams, habitat) for all combined well types and for each separate well type.

Similar to the overall PPR analyses, each county was ranked on the basis of the surface area of wetlands and length 


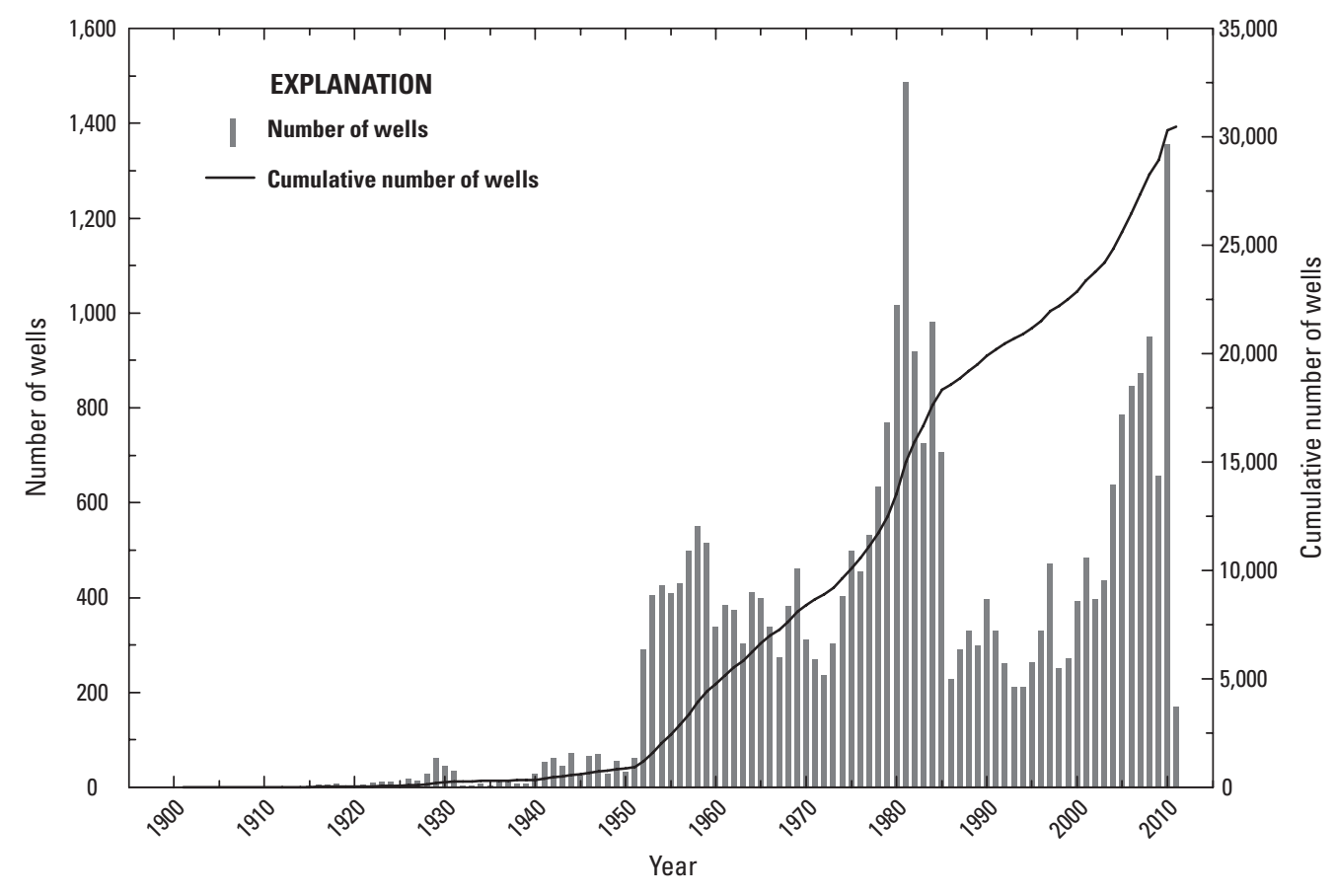

Figure C-3. Number of permitted and drilled wells by drilling year; there were 842 wells that did not have a drilling date associated with them. Data represent the entire year from 1901 to 2010 and January 1 through February 18, 2011.
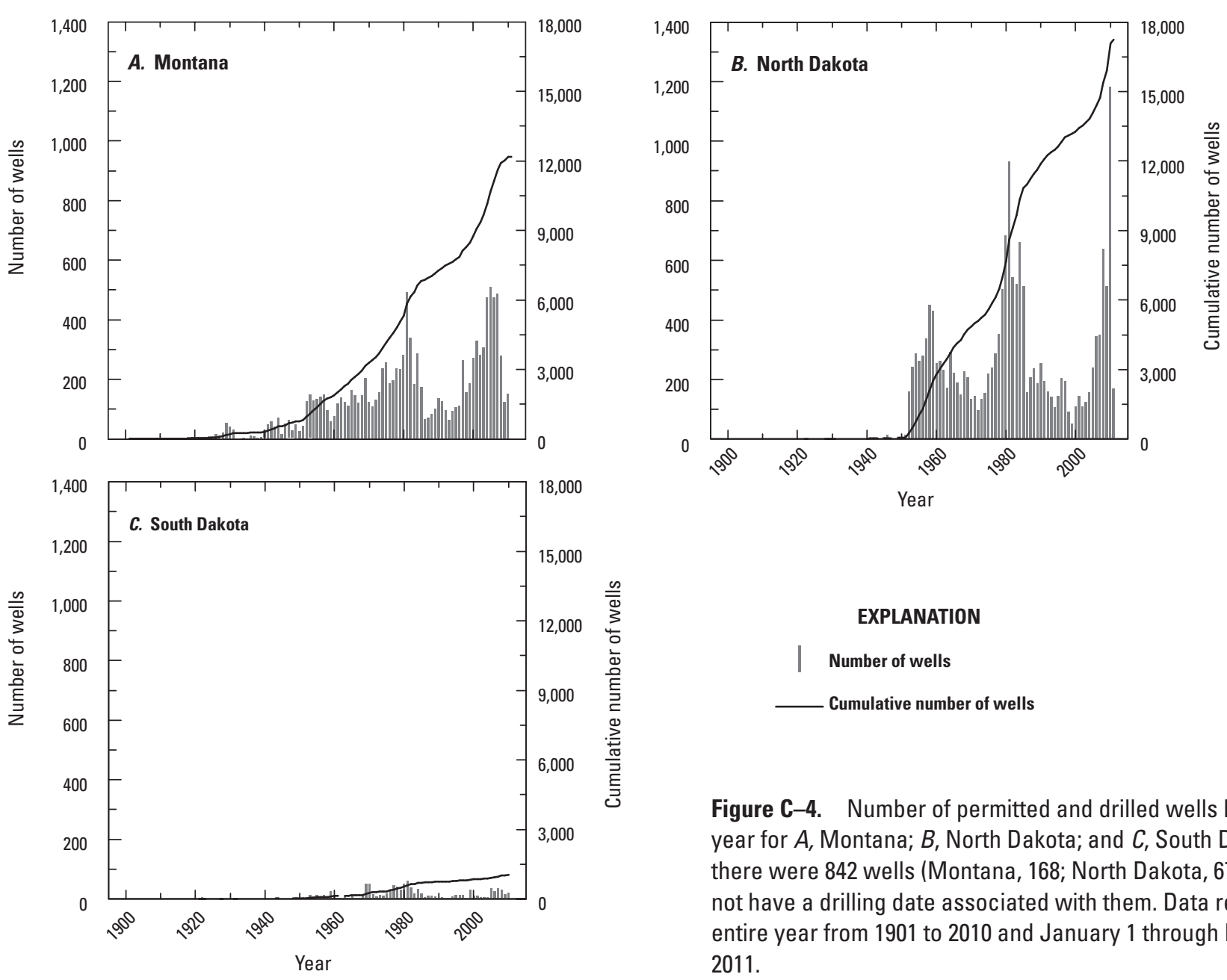

Figure C-4. Number of permitted and drilled wells by drilling year for $A$, Montana; $B$, North Dakota; and $C$, South Dakota; there were 842 wells (Montana, 168; North Dakota, 674) that did not have a drilling date associated with them. Data represent the entire year from 1901 to 2010 and January 1 through February 18, 2011. 

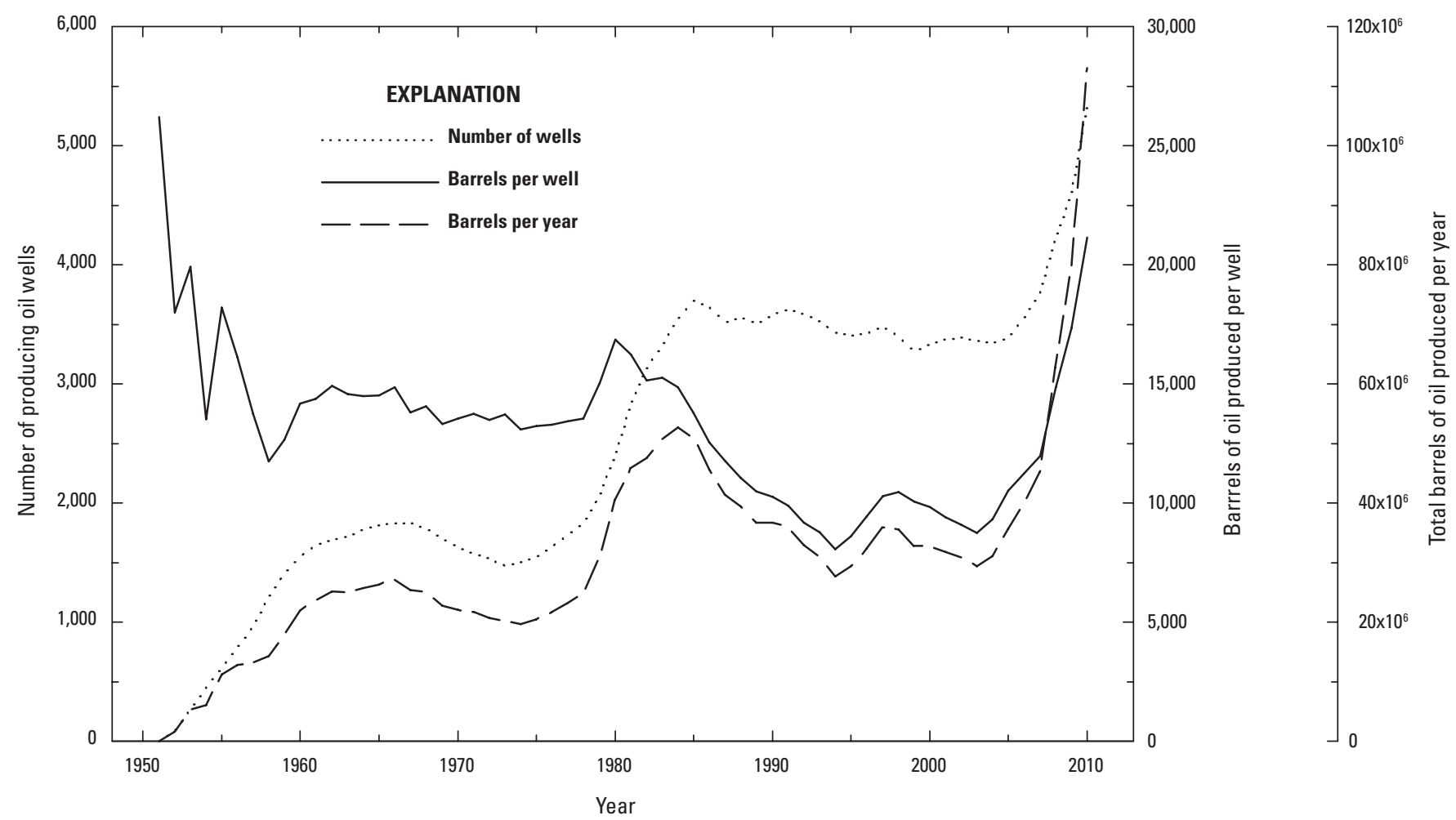

Figure C-5. Number of producing wells, barrels of oil produced per well, and total barrels of oil produced per year for North Dakota from 1951 to 2010.

of streams within the $0.4-\mathrm{km}$ buffers around wells drilled prior to 1980 . The seven counties with the greatest surface area of wetlands or kilometers of streams proximate to the pre-1980 wells were: Bottineau (N. Dak.), Burke (N. Dak.), Sheridan (Mont.), Renville (N. Dak.), Ward (N. Dak.), Phillips (Mont.), and Williams (N. Dak.) (fig. C-10). County area, surface area and number of wetlands, and stream length are presented by county for each of the three buffers in table $\mathrm{C}-14$. The seven counties represent the five counties with the highest mean ranks based on wetlands and streams; Bottineau, Burke, and Renville Counties ranked in the top five for both variables.

\section{U.S. Fish and Wildlife Service Lands}

There were approximately $1,716 \mathrm{~km}^{2}$ of USFWS lands in the PPR part of the study area, and 323, 604, and 1,233 wells were identified within the $0.4-\mathrm{km}, 0.8-\mathrm{km}$, and $1.6-\mathrm{km}$ buffers around these lands, respectively. Additionally, $67,110 \mathrm{~km}^{2}$ (51,797 wetlands), $72,779 \mathrm{~km}^{2}$ (92,628 wetlands), and 81,505 $\mathrm{km}^{2}(200,629$ wetlands) of wetlands and $1,215,1,702$, and $2,913 \mathrm{~km}$ of streams were identified within the small, intermediate, and large buffers, respectively. The area of USFWS lands, total buffer area around these lands (including parcel), number of wells, surface area of wetlands, and length of streams for each of the three buffers are presented by county in table $\mathrm{C}-15$. There were five counties that contained at least
10 wells within each of the buffer zones, and these counties were assigned a mean rank based on the number of wells and extent of aquatic resources on or adjacent to USFWS lands. On the basis of these ranks, Bottineau County (N. Dak.) contained the greatest number of wells and aquatic resources on or near USFWS lands, followed by Sheridan (Mont.), Renville (N. Dak.), Burke (N. Dak.), and Divide (N Dak.) (fig. C-11).

In addition to the above proximity analysis, the numbers of USFWS conservation easement land parcels that were intersected by the three buffers around wells were identified to determine the degree at which these lands are proximate to wells. On the basis of this simple assessment, it was determined that the $0.4-\mathrm{km}, 0.8-\mathrm{km}$, and $1.6-\mathrm{km}$ buffers intersected $1,792,2,455$, and 3,613 easement contracts in the PPR of the study area, respectively. Although an accurate number of how many wetlands are associated with the easement tracts intersected by the buffers is not known, the number is likely large because data suggest that the mean wetland density in the PPR part of the study area is approximately 11 wetlands/ $\mathrm{km}^{2}$, and about one-third of wetlands were within the $1.6-\mathrm{km}$ buffer around wells. The actual number of wetlands was not determined because a GIS database of easement boundaries was unavailable; a spatial layer containing the three buffers was provided to the USFWS, and they provided the aforementioned summaries. 
Table C-6. Number and percentage of wells drilled in each Soil Survey Geographic database (SSURGO) soil drainage classification.

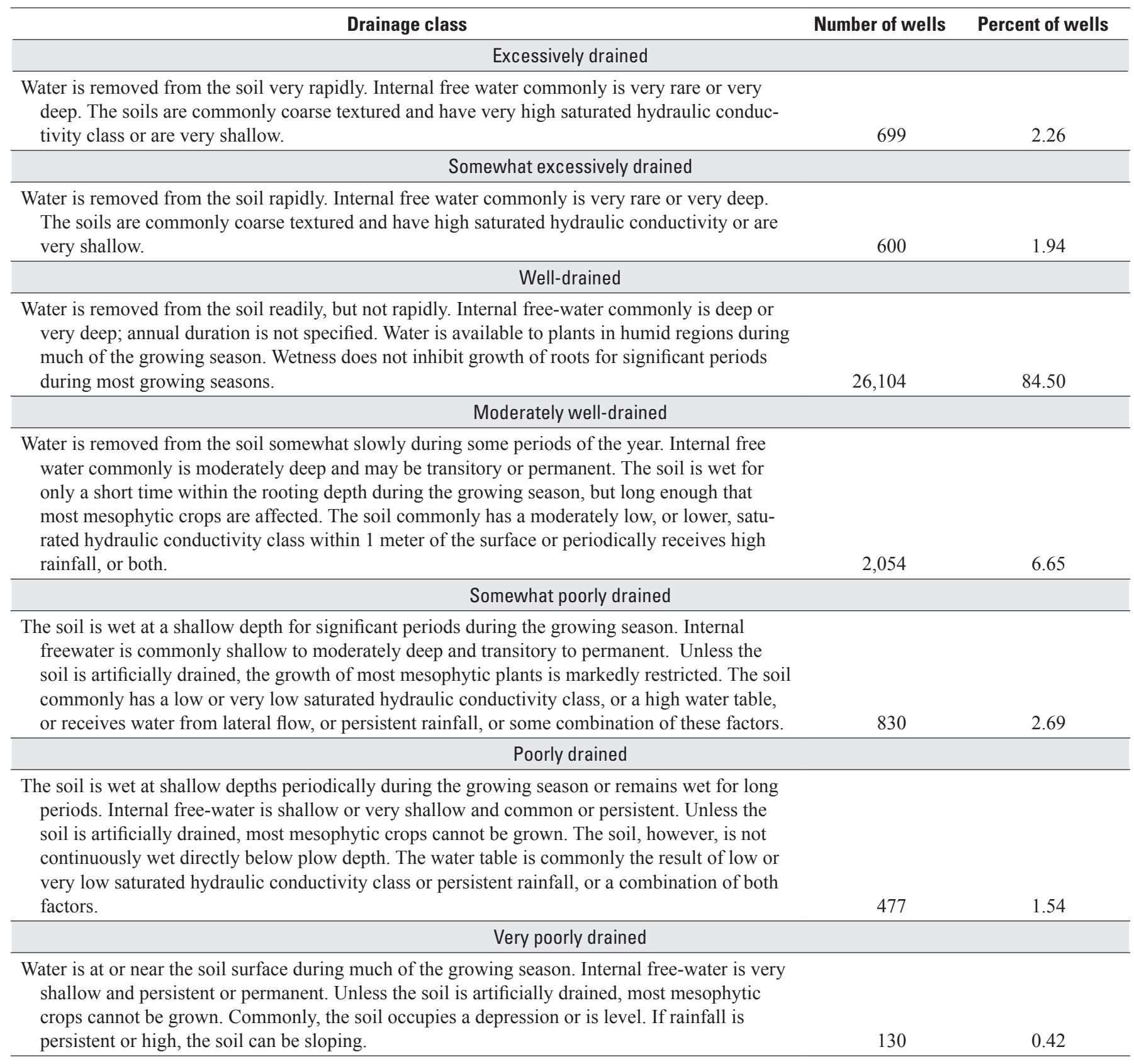

\section{Discussion}

The Williston Basin of the United States is in the midst of an oil boom driven by technological advances that allow for recovery from large hydrocarbon reservoirs associated with deep, low-permeability geologic formations. Concerns have been raised over potential environmental effects associated with past and current oil and gas exploration and recovery. Chief among these concerns is the contamination of wetlands, streams, and shallow groundwater by brines produced with oil and gas. Previous studies have demonstrated brine contamination to aquatic resources, primarily from oil and gas recovery operations prior to the 1980s (Reiten, 1991; Reiten and Tischmak, 1993). However, little research has been performed to assess current effects, and regionwide assessments are lacking. This study characterized the Williston Basin in terms of oil and gas wells and aquatic resources, and counties were identified with the greatest number of wells, wetlands, and streams. 


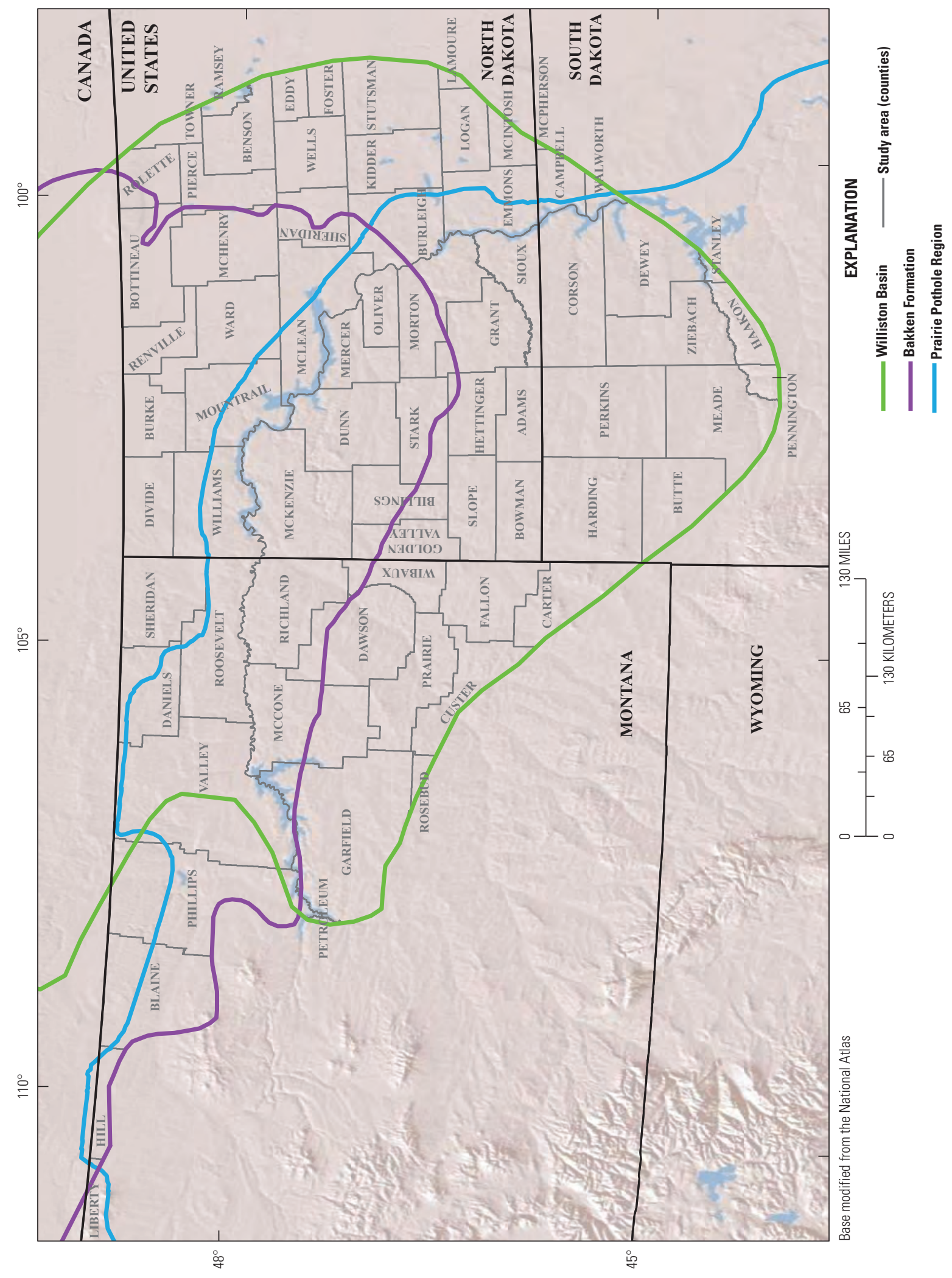

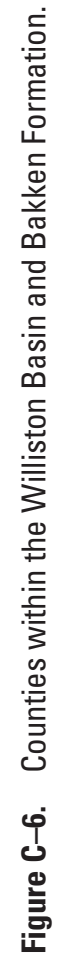


Table C-7. County area and number and density of wells per county in the Williston Basin.

[Well information is provided separately for all wells (all years) and only those wells drilled prior to $1980 . \mathrm{km}^{2}$, square kilometer; $<$, less than; --, no record]

\begin{tabular}{|c|c|c|c|c|c|c|}
\hline \multirow{2}{*}{ State } & \multirow{2}{*}{ County } & \multirow{2}{*}{$\begin{array}{c}\text { County area, } \\
\text { km² }^{2}\end{array}$} & \multicolumn{2}{|c|}{ Number of wells } & \multicolumn{2}{|c|}{ Density of wells } \\
\hline & & & All years & Pre-1980 & All years & Pre-1980 \\
\hline Montana & Blaine & 6,686 & 1,099 & 497 & 0.16 & 0.07 \\
\hline Montana & Carter & 3,609 & 98 & 74 & 0.03 & 0.02 \\
\hline Montana & Custer & 3,414 & 55 & 47 & 0.02 & 0.01 \\
\hline Montana & Daniels & 3,694 & 162 & 79 & 0.04 & 0.02 \\
\hline Montana & Dawson & 6,173 & 348 & 209 & 0.06 & 0.03 \\
\hline Montana & Fallon & 4,202 & 2,719 & 955 & 0.65 & 0.23 \\
\hline Montana & Garfield & 11,354 & 99 & 75 & 0.01 & 0.01 \\
\hline Montana & Hill & 1,244 & 232 & 81 & 0.19 & 0.07 \\
\hline Montana & Liberty & 147 & 66 & 53 & 0.45 & 0.36 \\
\hline Montana & McCone & 6,947 & 330 & 257 & 0.05 & 0.04 \\
\hline Montana & Phillips & 9,461 & 2,447 & 962 & 0.26 & 0.10 \\
\hline Montana & Prairie & 4,513 & 85 & 63 & 0.02 & 0.01 \\
\hline Montana & Richland & 5,450 & 1,624 & 350 & 0.30 & 0.06 \\
\hline Montana & Roosevelt & 6,134 & 1,006 & 514 & 0.16 & 0.08 \\
\hline Montana & Rosebud & 429 & 3 & 3 & 0.01 & 0.01 \\
\hline Montana & Sheridan & 4,414 & 1,050 & 516 & 0.24 & 0.12 \\
\hline Montana & Valley & 13,110 & 621 & 320 & 0.05 & 0.02 \\
\hline Montana & Wibaux & 2,303 & 303 & 156 & 0.13 & 0.07 \\
\hline North Dakota & Adams & 2,561 & 11 & 5 & 0.00 & 0.00 \\
\hline North Dakota & Benson & 3,434 & 19 & 19 & 0.01 & 0.01 \\
\hline North Dakota & Billings & 2,987 & 1,427 & 412 & 0.48 & 0.14 \\
\hline North Dakota & Bottineau & 4,397 & 2,154 & 1,381 & 0.49 & 0.31 \\
\hline North Dakota & Bowman & 3,023 & 1,204 & 287 & 0.40 & 0.09 \\
\hline North Dakota & Burke & 2,924 & 1,413 & 824 & 0.48 & 0.28 \\
\hline North Dakota & Burleigh & 4,321 & 49 & 44 & 0.01 & 0.01 \\
\hline North Dakota & Divide & 3,353 & 630 & 195 & 0.19 & 0.06 \\
\hline North Dakota & Dunn & 5,392 & 1,153 & 285 & 0.21 & 0.05 \\
\hline North Dakota & Eddy & 1,165 & 5 & 5 & $<0.01$ & $<0.01$ \\
\hline North Dakota & Emmons & 4,029 & 37 & 25 & 0.01 & 0.01 \\
\hline North Dakota & Foster & 1,263 & 11 & 11 & 0.01 & 0.01 \\
\hline North Dakota & Golden Valley & 2,596 & 243 & 72 & 0.09 & 0.03 \\
\hline North Dakota & Grant & 4,314 & 28 & 23 & 0.01 & 0.01 \\
\hline North Dakota & Hettinger & 2,937 & 28 & 14 & 0.01 & 0.00 \\
\hline North Dakota & Kidder & 3,711 & 4 & 4 & $<0.01$ & $<0.01$ \\
\hline North Dakota & Logan & 2,553 & 18 & 18 & 0.01 & 0.01 \\
\hline North Dakota & McHenry & 4,951 & 162 & 115 & 0.03 & 0.02 \\
\hline North Dakota & McIntosh & 1,324 & 4 & 4 & $<0.01$ & $<0.01$ \\
\hline North Dakota & McKenzie & 7,408 & 3,033 & 1,104 & 0.41 & 0.15 \\
\hline North Dakota & McLean & 6,031 & 126 & 36 & 0.02 & 0.01 \\
\hline
\end{tabular}


Table C-7. County area and number and density of wells per county in the Williston Basin.-Continued

[Well information is provided separately for all wells (all years) and only those wells drilled prior to $1980 . \mathrm{km}^{2}$, square kilometer; $<$, less than; --, no record]

\begin{tabular}{|c|c|c|c|c|c|c|}
\hline \multirow{2}{*}{ State } & \multirow{2}{*}{ County } & \multirow{2}{*}{$\begin{array}{c}\text { County area, } \\
\text { km² }^{2}\end{array}$} & \multicolumn{2}{|c|}{ Number of wells } & \multicolumn{2}{|c|}{ Density of wells } \\
\hline & & & All years & Pre-1980 & All years & Pre-1980 \\
\hline North Dakota & Mercer & 2,882 & 32 & 22 & 0.01 & 0.01 \\
\hline North Dakota & Morton & 5,038 & 38 & 26 & 0.01 & 0.01 \\
\hline North Dakota & Mountrail & 5,028 & 1,491 & 330 & 0.30 & 0.07 \\
\hline North Dakota & Oliver & 1,893 & 16 & 13 & 0.01 & 0.01 \\
\hline North Dakota & Pierce & 2,804 & 43 & 36 & 0.02 & 0.01 \\
\hline North Dakota & Ramsey & 549 & 3 & 3 & 0.01 & 0.01 \\
\hline North Dakota & Renville & 2,312 & 1,336 & 761 & 0.58 & 0.33 \\
\hline North Dakota & Rolette & 2,397 & 49 & 34 & 0.02 & 0.01 \\
\hline North Dakota & Sheridan & 2,604 & 13 & 9 & $<0.01$ & $<0.01$ \\
\hline North Dakota & Sioux & 2,922 & 6 & 5 & $<0.01$ & $<0.01$ \\
\hline North Dakota & Slope & 3,159 & 152 & 88 & 0.05 & 0.03 \\
\hline North Dakota & Stark & 3,472 & 544 & 239 & 0.16 & 0.07 \\
\hline North Dakota & Stutsman & 4,511 & 21 & 19 & $<0.01$ & $<0.01$ \\
\hline North Dakota & Towner & 1,059 & 5 & 5 & $<0.01$ & $<0.01$ \\
\hline North Dakota & Ward & 5,325 & 450 & 228 & 0.08 & 0.04 \\
\hline North Dakota & Wells & 3,342 & 27 & 21 & 0.01 & 0.01 \\
\hline North Dakota & Williams & 5,563 & 1,933 & 935 & 0.35 & 0.17 \\
\hline South Dakota & Butte & 3,996 & 78 & 35 & 0.02 & 0.01 \\
\hline South Dakota & Campbell & 1,760 & 7 & 7 & $<0.01$ & $<0.01$ \\
\hline South Dakota & Corson & 6,551 & 30 & 27 & $<0.01$ & $<0.01$ \\
\hline South Dakota & Dewey & 5,545 & 33 & 28 & 0.01 & 0.01 \\
\hline South Dakota & Haakon & 1,805 & 32 & 31 & 0.02 & 0.02 \\
\hline South Dakota & Harding & 6,935 & 780 & 286 & 0.11 & 0.04 \\
\hline South Dakota & Meade & 6,422 & 29 & 22 & $<0.01$ & $<0.01$ \\
\hline South Dakota & Pennington & 718 & 2 & 1 & $<0.01$ & $<0.01$ \\
\hline South Dakota & Perkins & 7,486 & 30 & 26 & $<0.01$ & $<0.01$ \\
\hline South Dakota & Stanley & 236 & 1 & -- & $<0.01$ & -- \\
\hline South Dakota & Walworth & 624 & 2 & 2 & $<0.01$ & $<0.01$ \\
\hline South Dakota & Ziebach & 5,105 & 17 & 16 & $<0.01$ & $<0.01$ \\
\hline Total & & 269,997 & 31,306 & 13,349 & & \\
\hline
\end{tabular}




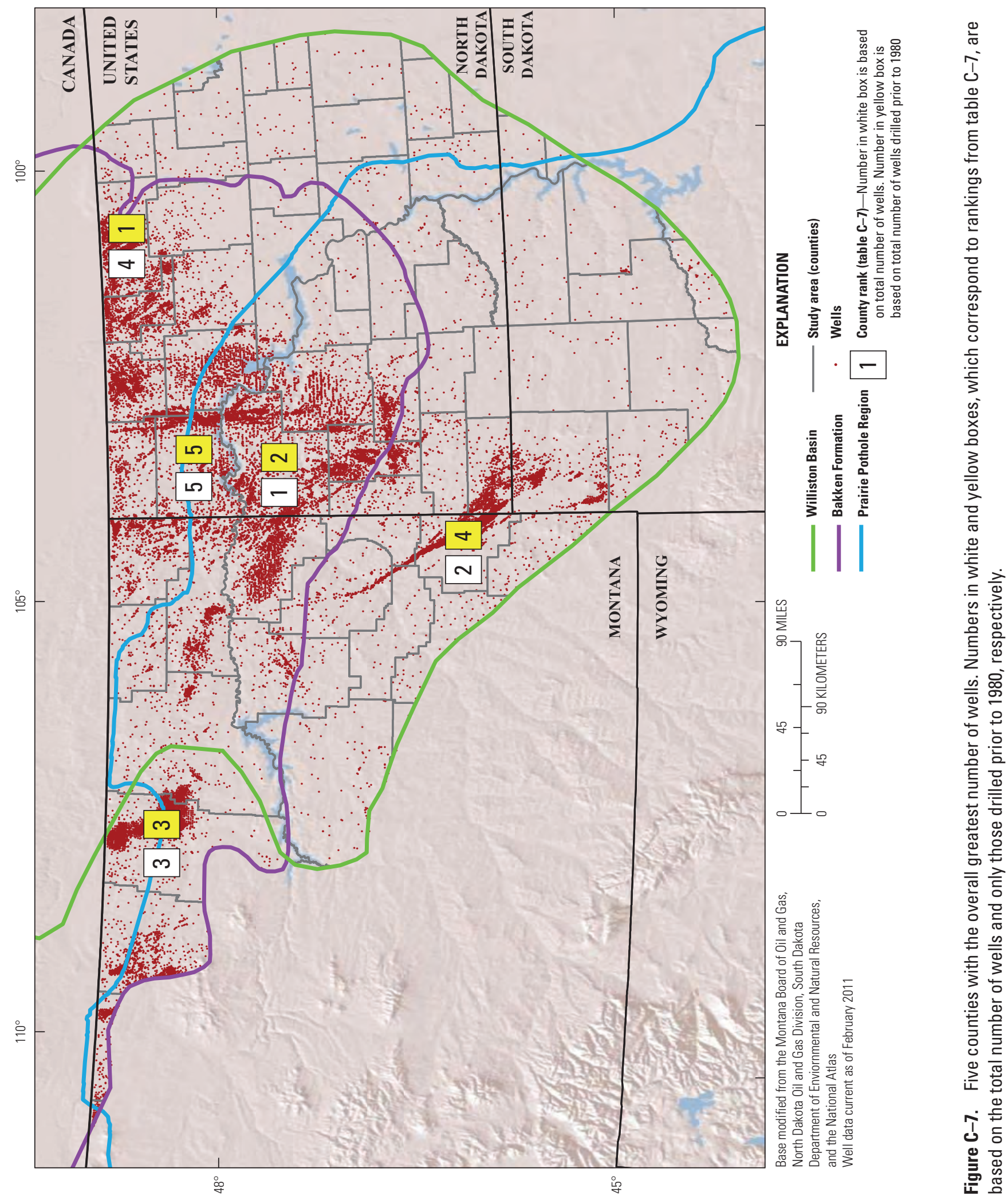




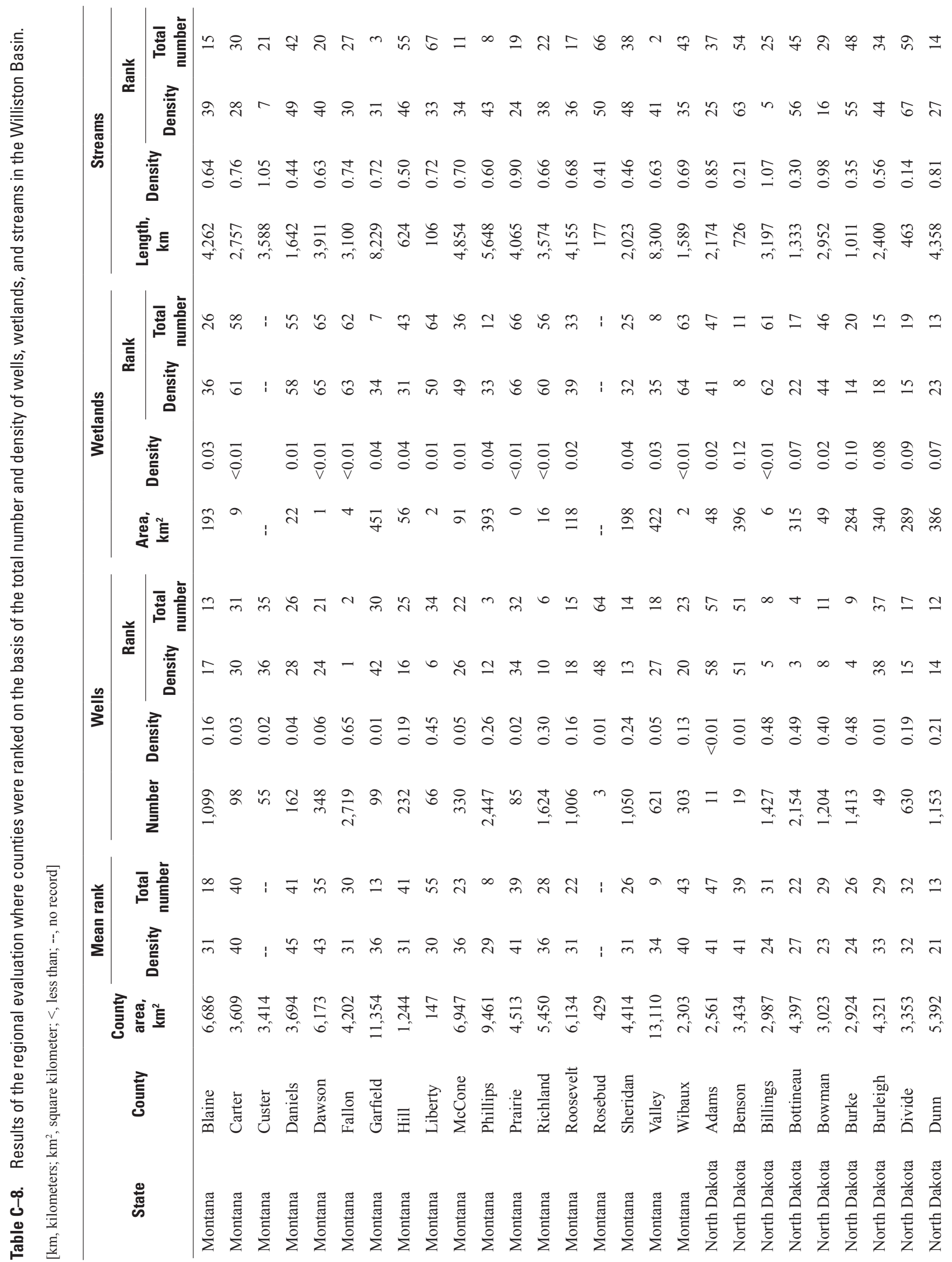




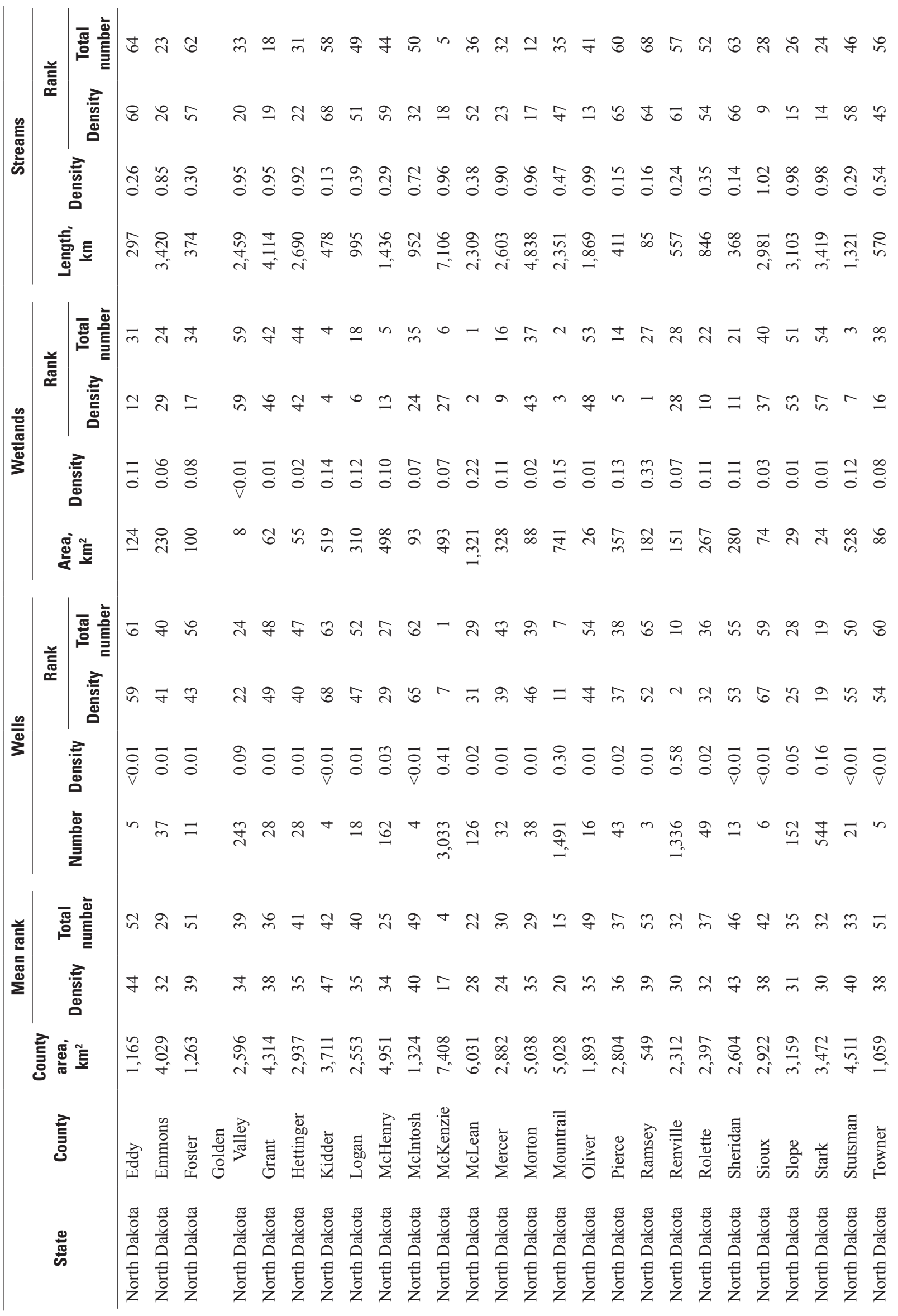




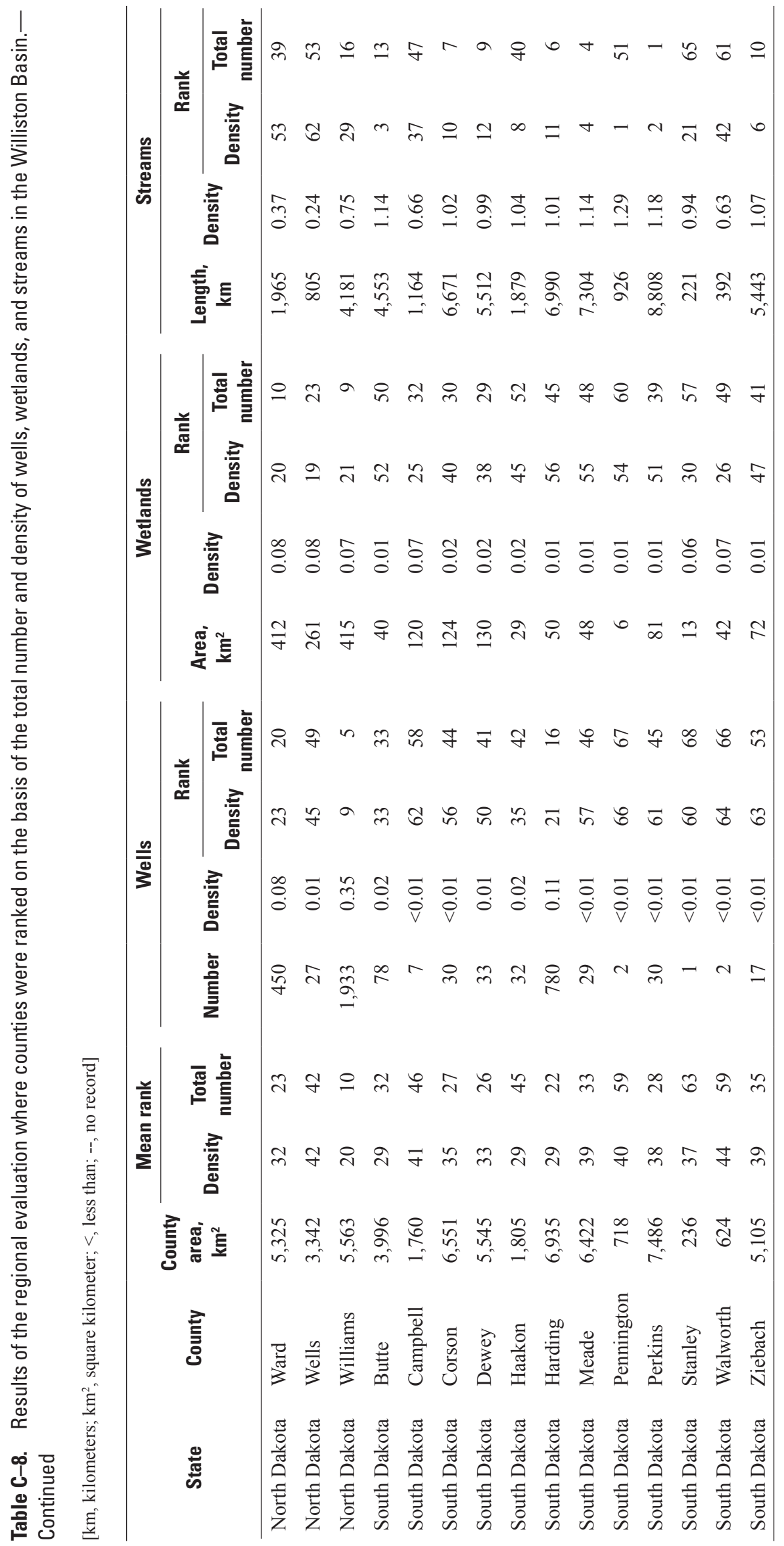




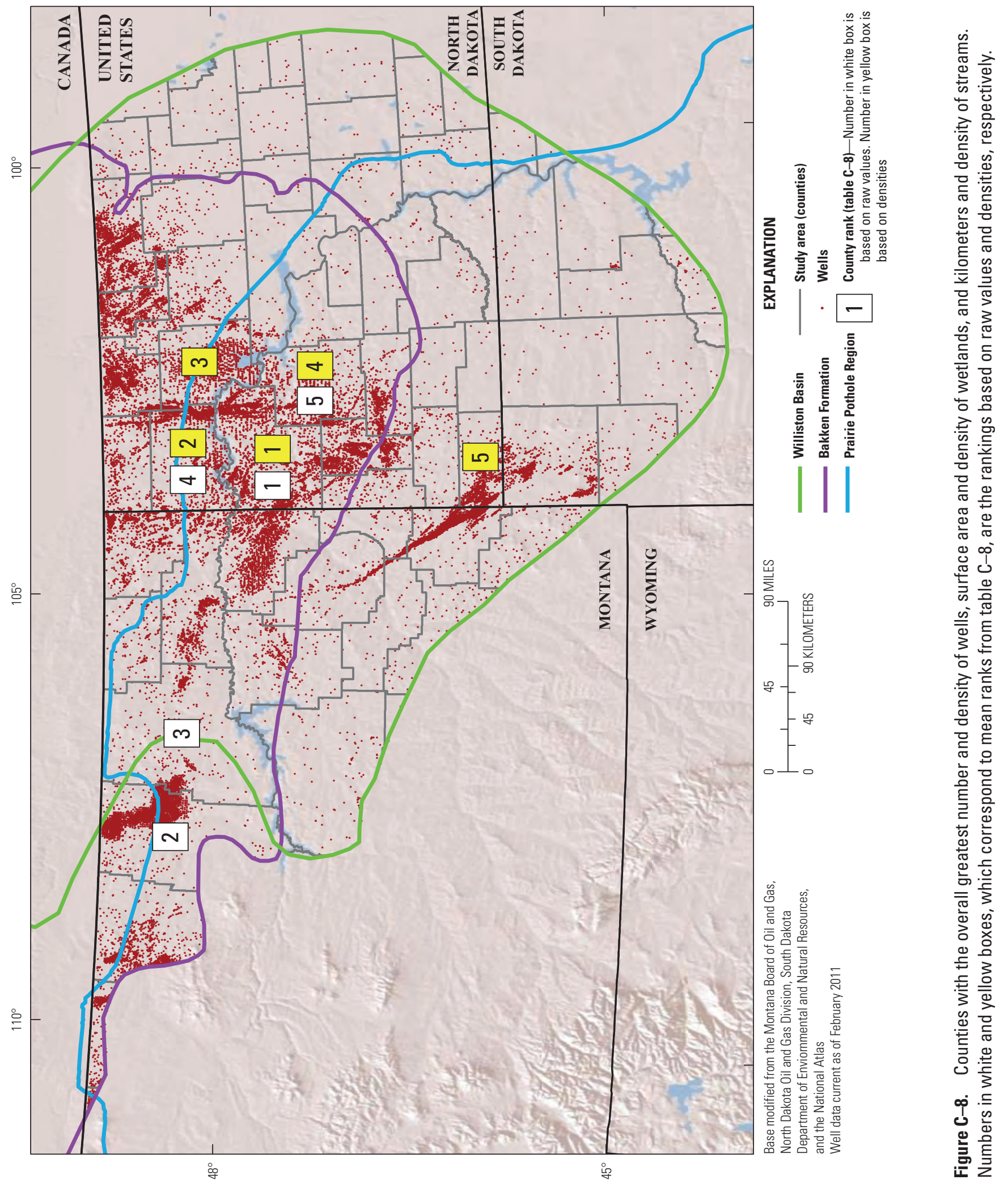


Table C-9. Surface area and total number of wetlands within each radial buffer $(0.4 \mathrm{~km}, 0.8 \mathrm{~km}$, $1.6 \mathrm{~km}$ ) around the 10,361 wells in the Prairie Pothole Region portion of the Williston Basin.

[km, kilometers; $\mathrm{km}^{2}$, square kilometer; $<$, less than]

\begin{tabular}{|c|c|c|c|c|c|c|}
\hline \multirow{2}{*}{$\begin{array}{c}\text { Wetland } \\
\text { classification }\end{array}$} & \multicolumn{2}{|c|}{ 0.4-km buffer } & \multicolumn{2}{|c|}{ 0.8-km buffer } & \multicolumn{2}{|c|}{ 1.6-km buffer } \\
\hline & $\begin{array}{c}\text { Area, } \\
\text { km² }^{2}\end{array}$ & Number & $\begin{array}{c}\text { Area, } \\
\text { km² }^{2}\end{array}$ & Number & $\begin{array}{l}\text { Area, } \\
\text { km² }^{2}\end{array}$ & Number \\
\hline \multicolumn{7}{|c|}{ Well type-All } \\
\hline Temporary & 39 & 27,499 & 83 & 64,911 & 163 & 125,641 \\
\hline Seasonal & 135 & 31,128 & 289 & 73,120 & 577 & 148,743 \\
\hline Semipermanent & 115 & 3,618 & 218 & 8,006 & 416 & 16,589 \\
\hline Riverine & 25 & 95 & 40 & 142 & 49 & 235 \\
\hline Lake & 187 & 378 & 346 & 799 & 577 & 1,537 \\
\hline Total & 501 & 62,718 & 975 & 146,978 & 1,780 & 292,745 \\
\hline \multicolumn{7}{|c|}{ Well type-Confidential } \\
\hline Temporary & 1 & 734 & 4 & 2,581 & 12 & 8,715 \\
\hline Seasonal & 6 & 1,389 & 21 & 4,739 & 65 & 15,684 \\
\hline Semipermanent & 7 & 167 & 18 & 518 & 56 & 1,686 \\
\hline Riverine & 0.4 & 2 & 3 & 9 & 4 & 12 \\
\hline Lake & 16 & 18 & 25 & 41 & 100 & 155 \\
\hline Total & 30 & 2,310 & 70 & 7,888 & 238 & 26,252 \\
\hline \multicolumn{7}{|c|}{ Well type-Dry hole } \\
\hline Temporary & 27 & 17,863 & 74 & 53,710 & 158 & 116,542 \\
\hline Seasonal & 95 & 19,183 & 246 & 56,972 & 543 & 129,899 \\
\hline Semipermanent & 95 & 2,245 & 209 & 6,245 & 427 & 14,631 \\
\hline Riverine & 33 & 86 & 53 & 131 & 85 & 227 \\
\hline Lake & 112 & 295 & 376 & 679 & 880 & 1,353 \\
\hline Total & 363 & 39,672 & 958 & 117,737 & 2,092 & 262,652 \\
\hline \multicolumn{7}{|c|}{ Well type-Gas } \\
\hline Temporary & 0.1 & 14 & 0.4 & 67 & 1 & 278 \\
\hline Seasonal & 1 & 43 & 1 & 188 & 4 & 683 \\
\hline Semipermanent & 0.2 & 10 & 1 & 28 & 4 & 102 \\
\hline Riverine & 7 & 1 & 7 & 1 & 13 & 1 \\
\hline Lake & 2 & 2 & 3 & 7 & 11 & 19 \\
\hline Total & 10 & 70 & 12 & 291 & 33 & 1,083 \\
\hline \multicolumn{7}{|c|}{ Well type-Injection } \\
\hline Temporary & 3 & 1,980 & 9 & 6,092 & 20 & 16,711 \\
\hline Seasonal & 12 & 2,446 & 29 & 6,601 & 66 & 16,870 \\
\hline Semipermanent & 10 & 322 & 24 & 765 & 46 & 1,797 \\
\hline Riverine & 8 & 9 & 17 & 16 & 30 & 26 \\
\hline Lake & 31 & 39 & 171 & 70 & 317 & 127 \\
\hline Total & 65 & 4,796 & 249 & 13,544 & 480 & 35,531 \\
\hline
\end{tabular}


Table C-9. Surface area and total number of wetlands within each radial buffer $(0.4 \mathrm{~km}, 0.8 \mathrm{~km}$, $1.6 \mathrm{~km}$ ) around the 10,361 wells in the Prairie Pothole Region portion of the Williston Basin.Continued

[km, kilometers; $\mathrm{km}^{2}$, square kilometer; $<$, less than]

\begin{tabular}{|c|c|c|c|c|c|c|}
\hline \multirow{2}{*}{$\begin{array}{c}\text { Wetland } \\
\text { classification }\end{array}$} & \multicolumn{2}{|c|}{ 0.4-km buffer } & \multicolumn{2}{|c|}{ 0.8-km buffer } & \multicolumn{2}{|c|}{ 1.6-km buffer } \\
\hline & $\begin{array}{c}\text { Area, } \\
\text { km }^{2}\end{array}$ & Number & $\begin{array}{c}\text { Area, } \\
\text { km }^{2}\end{array}$ & Number & $\begin{array}{c}\text { Area, } \\
\text { km }^{2}\end{array}$ & Number \\
\hline \multicolumn{7}{|c|}{ Well type-0il } \\
\hline Temporary & 17 & 10,769 & 35 & 23,477 & 59 & 47,824 \\
\hline Seasonal & 61 & 12,758 & 127 & 27,039 & 248 & 57,422 \\
\hline Semipermanent & 57 & 1,496 & 110 & 3,031 & 176 & 6,116 \\
\hline Riverine & 21 & 27 & 35 & 39 & 40 & 53 \\
\hline Lake & 96 & 96 & 329 & 199 & 666 & 466 \\
\hline Total & 253 & 25,146 & 635 & 53,785 & 1,189 & 111,881 \\
\hline \multicolumn{7}{|c|}{ Well type-Stratigraphic test } \\
\hline Temporary & $<0.1$ & 2 & $<0.1$ & 6 & 0.1 & 25 \\
\hline Seasonal & $<0.1$ & 8 & $<0.1$ & 15 & 0.2 & 46 \\
\hline Semipermanent & 0.2 & 4 & 0.3 & 6 & 0.4 & 16 \\
\hline Riverine & 0.1 & 1 & 0.1 & 1 & 7 & 1 \\
\hline Lake & 36 & 1 & 37 & 1 & 37 & 3 \\
\hline Total & 37 & 16 & 37 & 29 & 44 & 91 \\
\hline \multicolumn{7}{|c|}{ Well type-Water } \\
\hline Temporary & 0.2 & 141 & 1 & 599 & 2 & 2,169 \\
\hline Seasonal & 1 & 228 & 3 & 796 & 9 & 2,611 \\
\hline Semipermanent & 2 & 32 & 2 & 83 & 5 & 274 \\
\hline Riverine & 0.3 & 2 & 0.4 & 3 & 0.4 & 4 \\
\hline Lake & 2 & 3 & 5 & 10 & 114 & 19 \\
\hline Total & 5 & 406 & 11 & 1,491 & 131 & $\mathbf{5 , 0 7 7}$ \\
\hline
\end{tabular}

Table C-10. Inventory of streams and piping plover critical habitat within each radial buffer $(0.4 \mathrm{~km}$, $0.8 \mathrm{~km}, 1.6 \mathrm{~km}$ ) around the 10,361 wells in the Prairie Pothole Region portion of the Williston Basin.

[km, kilometer; $\mathrm{km}^{2}$, square kilometer; <, less than; --, no record]

\begin{tabular}{|c|c|c|c|c|c|c|}
\hline \multirow[b]{2}{*}{ Well type } & \multicolumn{2}{|c|}{ 0.4-km buffer } & \multicolumn{2}{|c|}{ 0.8-km buffer } & \multicolumn{2}{|c|}{ 1.6-km buffer } \\
\hline & $\begin{array}{c}\text { Stream } \\
\text { length, } \\
\text { km }\end{array}$ & $\begin{array}{c}\text { Critical } \\
\text { habitat, } \\
\text { km² }^{2}\end{array}$ & $\begin{array}{c}\text { Stream } \\
\text { length, } \\
\text { km }\end{array}$ & $\begin{array}{c}\text { Critical } \\
\text { habitat, } \\
\text { km² }^{2}\end{array}$ & $\begin{array}{c}\text { Stream } \\
\text { length, } \\
\text { km }\end{array}$ & $\begin{array}{c}\text { Critical } \\
\text { habitat, } \\
\text { km² }^{2}\end{array}$ \\
\hline All & 1,380 & 5 & 3,291 & 22 & 7,147 & 79 \\
\hline Confidential & 34 & 0.1 & 151 & 1 & 546 & 4 \\
\hline Dry hole & 615 & 3 & 2,175 & 12 & 5,859 & 50 \\
\hline Gas & 337 & $<0.1$ & 616 & 0.1 & 961 & 2 \\
\hline Injection & 68 & 1 & 219 & 4 & 612 & 15 \\
\hline Oil & 379 & 1 & 891 & 7 & 1,984 & 38 \\
\hline Stratigraphic test & 2 & 0.4 & 4 & 1 & 9 & 2 \\
\hline Water & 6 & -- & 19 & -- & 66 & 0.2 \\
\hline
\end{tabular}



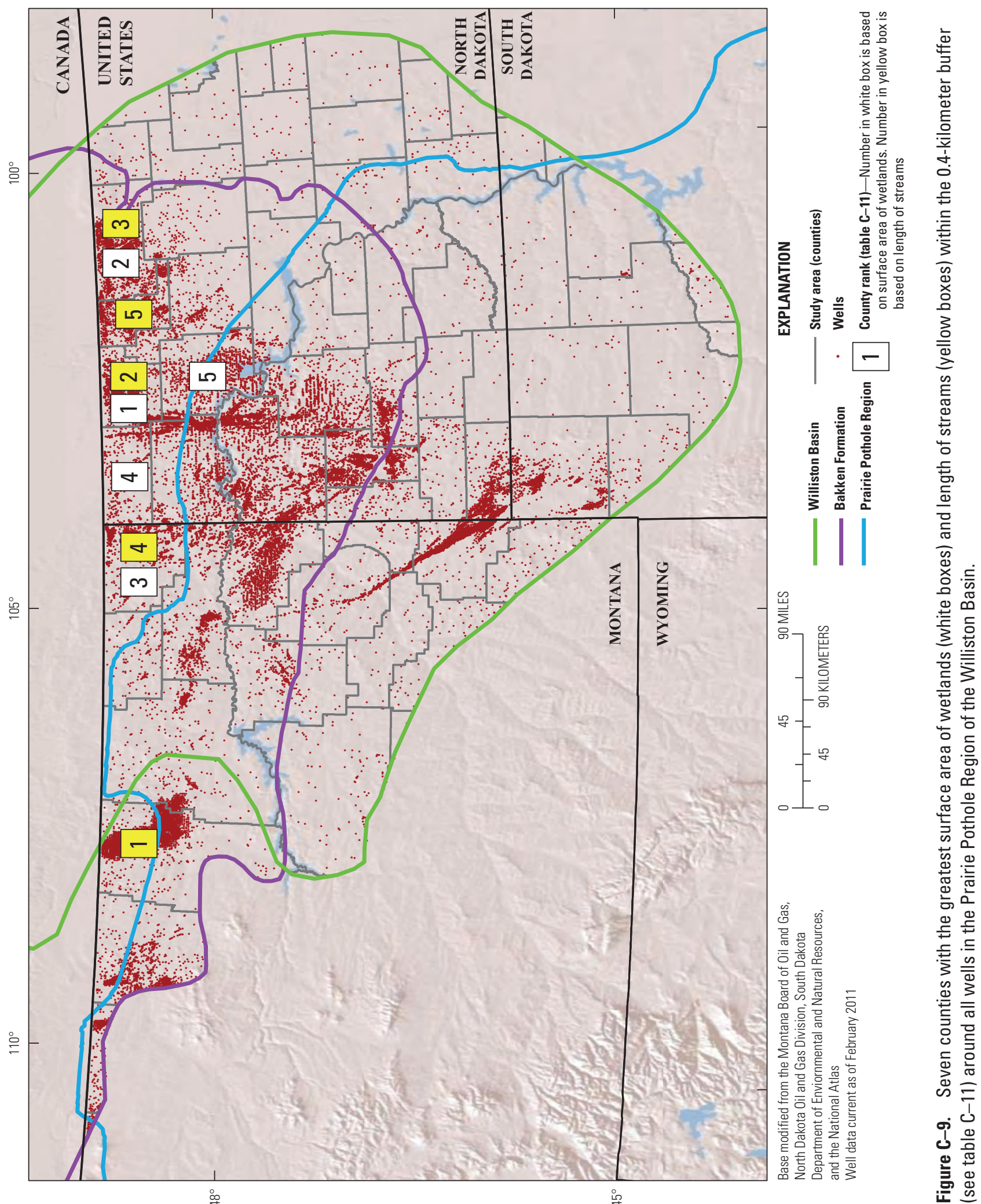


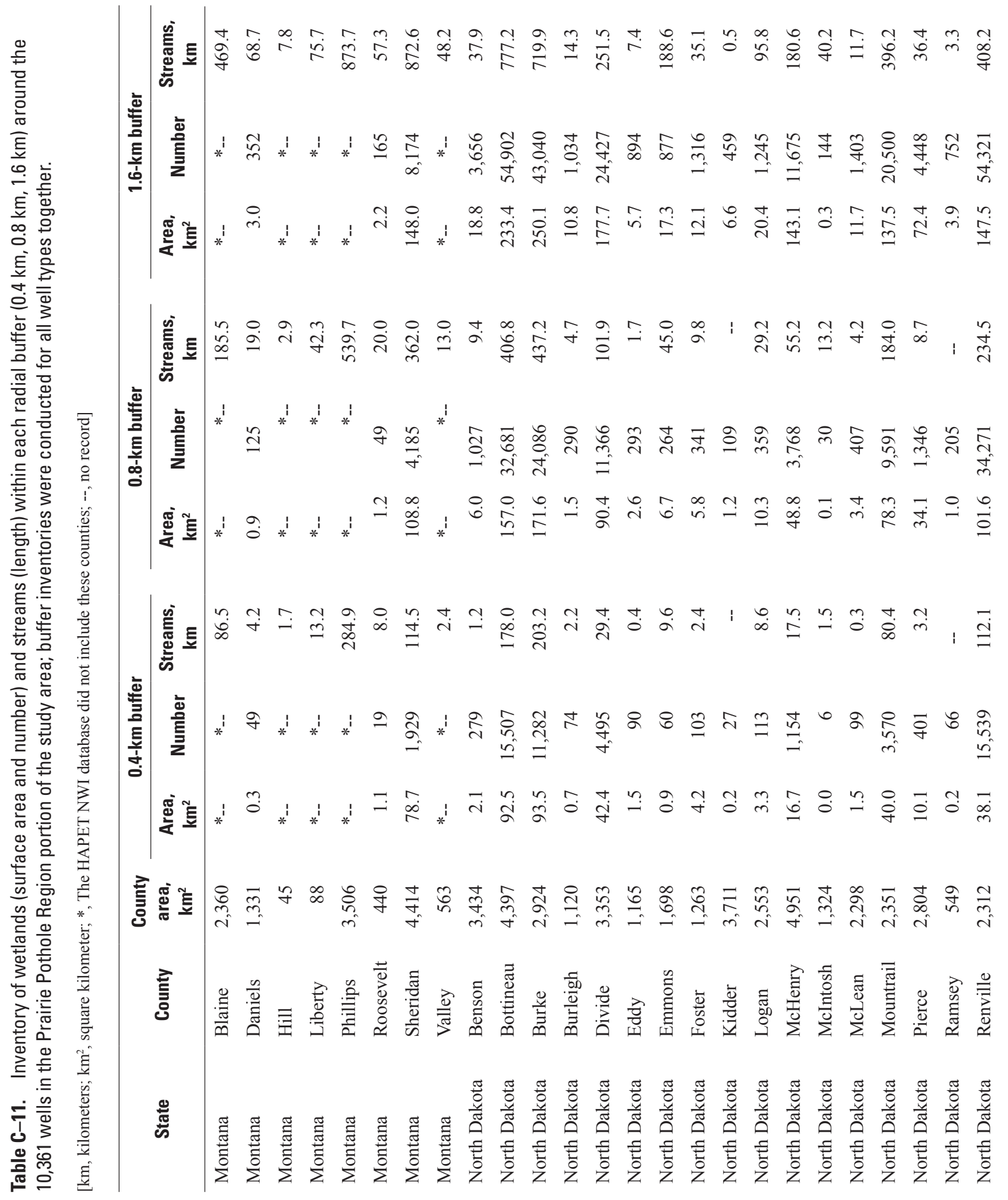




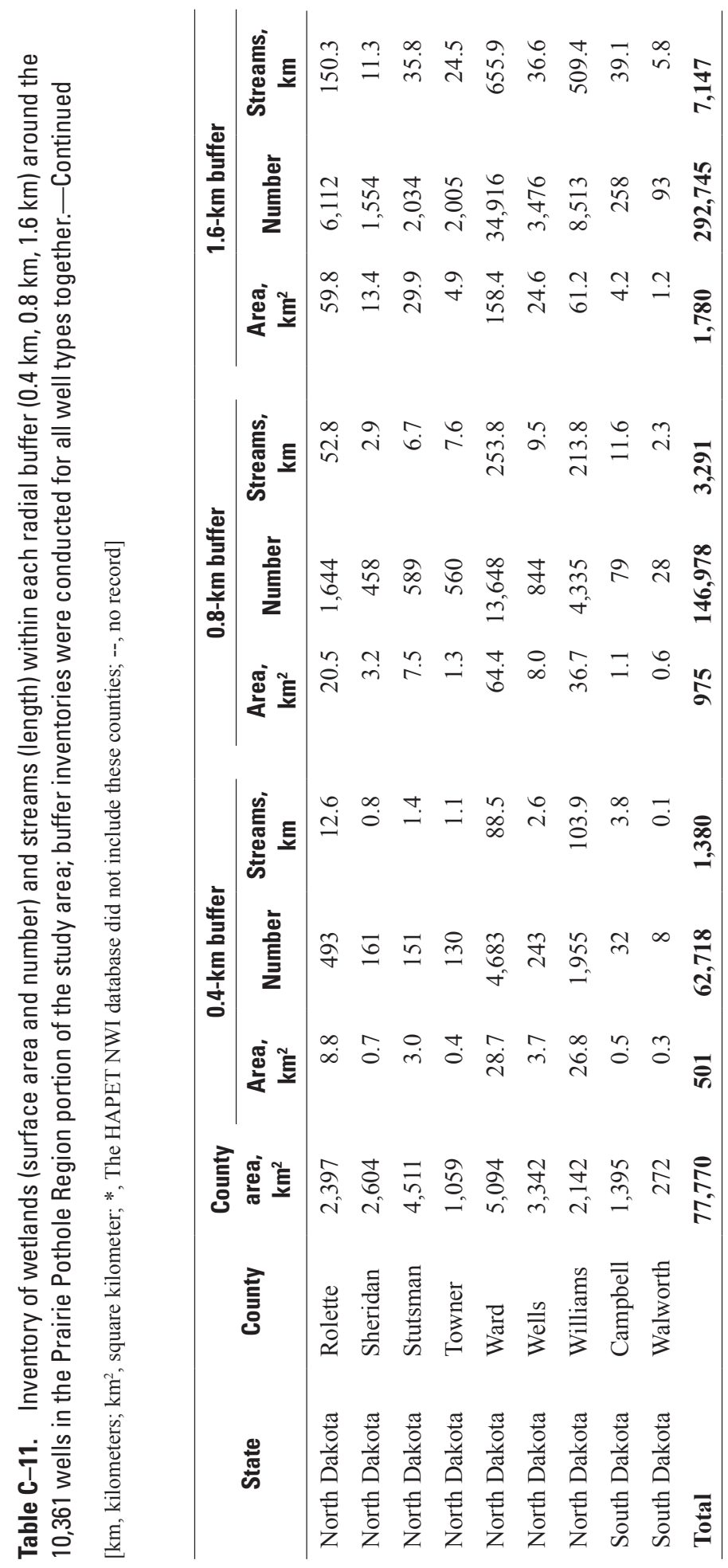


Table C-12. Inventory of wetlands (surface area and number) within each radial buffer $(0.4 \mathrm{~km}$, $0.8 \mathrm{~km}, 1.6 \mathrm{~km}$ ) around the 5,446 wells in the Prairie Pothole Region portion of the study area that were drilled prior to 1980 .

[km, kilometers; $\mathrm{km}^{2}$, square kilometer; --, no record]

\begin{tabular}{|c|c|c|c|c|c|c|}
\hline \multirow{2}{*}{$\begin{array}{c}\text { Wetland } \\
\text { classification }\end{array}$} & \multicolumn{2}{|c|}{ 0.4-km buffer } & \multicolumn{2}{|c|}{ 0.8-km buffer } & \multicolumn{2}{|c|}{ 1.6-km buffer } \\
\hline & $\begin{array}{c}\text { Area, } \\
\text { km² }^{2}\end{array}$ & Number & $\begin{array}{l}\text { Area, } \\
\text { km² }^{2}\end{array}$ & Number & $\begin{array}{l}\text { Area, } \\
\text { km² }^{2}\end{array}$ & Number \\
\hline \multicolumn{7}{|c|}{ Well type-All } \\
\hline Temporary & 25 & 16,506 & 56 & 41,880 & 123 & 91,884 \\
\hline Seasonal & 81 & 18,551 & 180 & 45,313 & 403 & 102,015 \\
\hline Semipermanent & 73 & 2,201 & 146 & 5,097 & 297 & 11,548 \\
\hline Riverine & 22 & 79 & 36 & 110 & 51 & 181 \\
\hline Lake & 83 & 246 & 187 & 510 & 413 & 1,177 \\
\hline Total & 285 & 37,583 & 605 & 92,910 & 1,288 & 206,805 \\
\hline \multicolumn{7}{|c|}{ Well type-Confidential } \\
\hline Temporary & -- & -- & 0.01 & 8 & 0.02 & 21 \\
\hline Seasonal & -- & -- & 0.02 & 1 & 0.1 & 8 \\
\hline Semipermanent & -- & -- & -- & -- & 0.1 & 2 \\
\hline Riverine & -- & -- & -- & -- & -- & -- \\
\hline Lake & -- & -- & -- & -- & -- & -- \\
\hline Total & -- & -- & 0.02 & 9 & 0.2 & 31 \\
\hline \multicolumn{7}{|c|}{ Well type-Dry hole } \\
\hline Temporary & 18 & 11,367 & 53 & 36,859 & 122 & 89,452 \\
\hline Seasonal & 61 & 12,218 & 165 & 38,988 & 403 & 98,403 \\
\hline Semipermanent & 65 & 1,460 & 149 & 4,350 & 313 & 11,093 \\
\hline Riverine & 23 & 74 & 47 & 106 & 70 & 178 \\
\hline Lake & 74 & 208 & 265 & 466 & 520 & 1,152 \\
\hline Total & 241 & 25,327 & 680 & 80,769 & 1,428 & 200,278 \\
\hline \multicolumn{7}{|c|}{ Well type-Gas } \\
\hline Temporary & 0.1 & 3 & 0.3 & 23 & 0.4 & 68 \\
\hline Seasonal & 0.2 & 18 & 0.4 & 79 & 1 & 259 \\
\hline Semipermanent & 0.01 & 1 & 0.2 & 9 & 0.5 & 33 \\
\hline Riverine & 7 & 1 & 7 & 1 & 13 & 1 \\
\hline Lake & 2 & 1 & 1 & 2 & 8 & 8 \\
\hline Total & 9 & 24 & 9 & 114 & 23 & 369 \\
\hline \multicolumn{7}{|c|}{ Well type-Injection } \\
\hline Temporary & 2 & 1,117 & 5 & 3,345 & 11 & 8,901 \\
\hline Seasonal & 7 & 1,431 & 17 & 3,905 & 38 & 9,804 \\
\hline Semipermanent & 5 & 175 & 14 & 448 & 29 & 1,073 \\
\hline Riverine & 7 & 5 & 15 & 12 & 22 & 22 \\
\hline Lake & 10 & 25 & 108 & 46 & 121 & 80 \\
\hline Total & 31 & 2,753 & 159 & 7,756 & 220 & 19,880 \\
\hline
\end{tabular}


Table C-12. Inventory of wetlands (surface area and number) within each radial buffer ( $0.4 \mathrm{~km}$, $0.8 \mathrm{~km}, 1.6 \mathrm{~km}$ ) around the 5,446 wells in the Prairie Pothole Region portion of the study area that were drilled prior to 1980 . - Continued

[km, kilometers; $\mathrm{km}^{2}$, square kilometer; --, no record]

\begin{tabular}{|c|c|c|c|c|c|c|}
\hline \multirow{2}{*}{$\begin{array}{c}\text { Wetland } \\
\text { classification }\end{array}$} & \multicolumn{2}{|c|}{ 0.4-km buffer } & \multicolumn{2}{|c|}{ 0.8-km buffer } & \multicolumn{2}{|c|}{ 1.6-km buffer } \\
\hline & $\begin{array}{c}\text { Area, } \\
\text { km² }^{2}\end{array}$ & Number & $\begin{array}{l}\text { Area, } \\
\text { km² }^{2}\end{array}$ & Number & $\begin{array}{c}\text { Area, } \\
\text { km² }^{2}\end{array}$ & Number \\
\hline \multicolumn{7}{|c|}{ Well type-0il } \\
\hline Temporary & 9 & 5,656 & 19 & 11,737 & 30 & 24,501 \\
\hline Seasonal & 29 & 6,689 & 55 & 12,616 & 97 & 24,742 \\
\hline Semipermanent & 32 & 797 & 58 & 1,448 & 74 & 2,724 \\
\hline Riverine & 4 & 17 & 28 & 27 & 29 & 38 \\
\hline Lake & 48 & 50 & 172 & 90 & 283 & 156 \\
\hline Total & 122 & 13,209 & 333 & 25,918 & 514 & 52,161 \\
\hline \multicolumn{7}{|c|}{ Well type-Water } \\
\hline Temporary & 0.1 & 91 & 0.4 & 386 & 1 & 1,409 \\
\hline Seasonal & 0.5 & 128 & 2 & 483 & 6 & 1,611 \\
\hline Semipermanent & 1 & 17 & 2 & 55 & 3 & 191 \\
\hline Riverine & 0.1 & 1 & 0.2 & 2 & 0.1 & 2 \\
\hline Lake & 2 & 3 & 2 & 9 & 13 & 17 \\
\hline Total & 3 & 240 & 6 & 935 & 23 & 3,230 \\
\hline
\end{tabular}

Table C-13. Inventory of streams and piping plover critical habitat within each radial buffer $(0.4 \mathrm{~km}, 0.8 \mathrm{~km}, 1.6 \mathrm{~km})$ around the 5,446 wells in the Prairie Pothole Region portion of the study area that were drilled prior to 1980.

[km, kilometer; $\mathrm{km}^{2}$, square kilometer; $<$, less than; --, no record]

\begin{tabular}{|c|c|c|c|c|c|c|}
\hline \multirow[b]{2}{*}{ Well type } & \multicolumn{2}{|c|}{ 0.4-km buffer } & \multicolumn{2}{|c|}{ 0.8-km buffer } & \multicolumn{2}{|c|}{ 1.6-km buffer } \\
\hline & $\begin{array}{c}\text { Stream } \\
\text { length, } \\
\text { km }\end{array}$ & $\begin{array}{c}\text { Critical } \\
\text { habitat, } \\
\text { km² }^{2}\end{array}$ & $\begin{array}{c}\text { Stream } \\
\text { length, } \\
\text { km }\end{array}$ & $\begin{array}{c}\text { Critical } \\
\text { habitat, } \\
\text { km² }^{2}\end{array}$ & $\begin{array}{c}\text { Stream } \\
\text { length, } \\
\text { km }\end{array}$ & $\begin{array}{c}\text { Critical } \\
\text { habitat, } \\
\text { km² }^{2}\end{array}$ \\
\hline All & 736 & 2 & 2,091 & 10 & 5,002 & 38 \\
\hline Confidential & -- & -- & -- & -- & 3 & -- \\
\hline Dry hole & 411 & 1 & 1,500 & 6 & 4,353 & 33 \\
\hline Gas & 110 & $<0.01$ & 375 & 0.1 & 665 & 2 \\
\hline Injection & 46 & 0.3 & 139 & 2 & 386 & 4 \\
\hline Oil & 222 & 1 & 444 & 3 & 919 & 14 \\
\hline Water & 3 & -- & 10 & -- & 34 & 0.2 \\
\hline
\end{tabular}




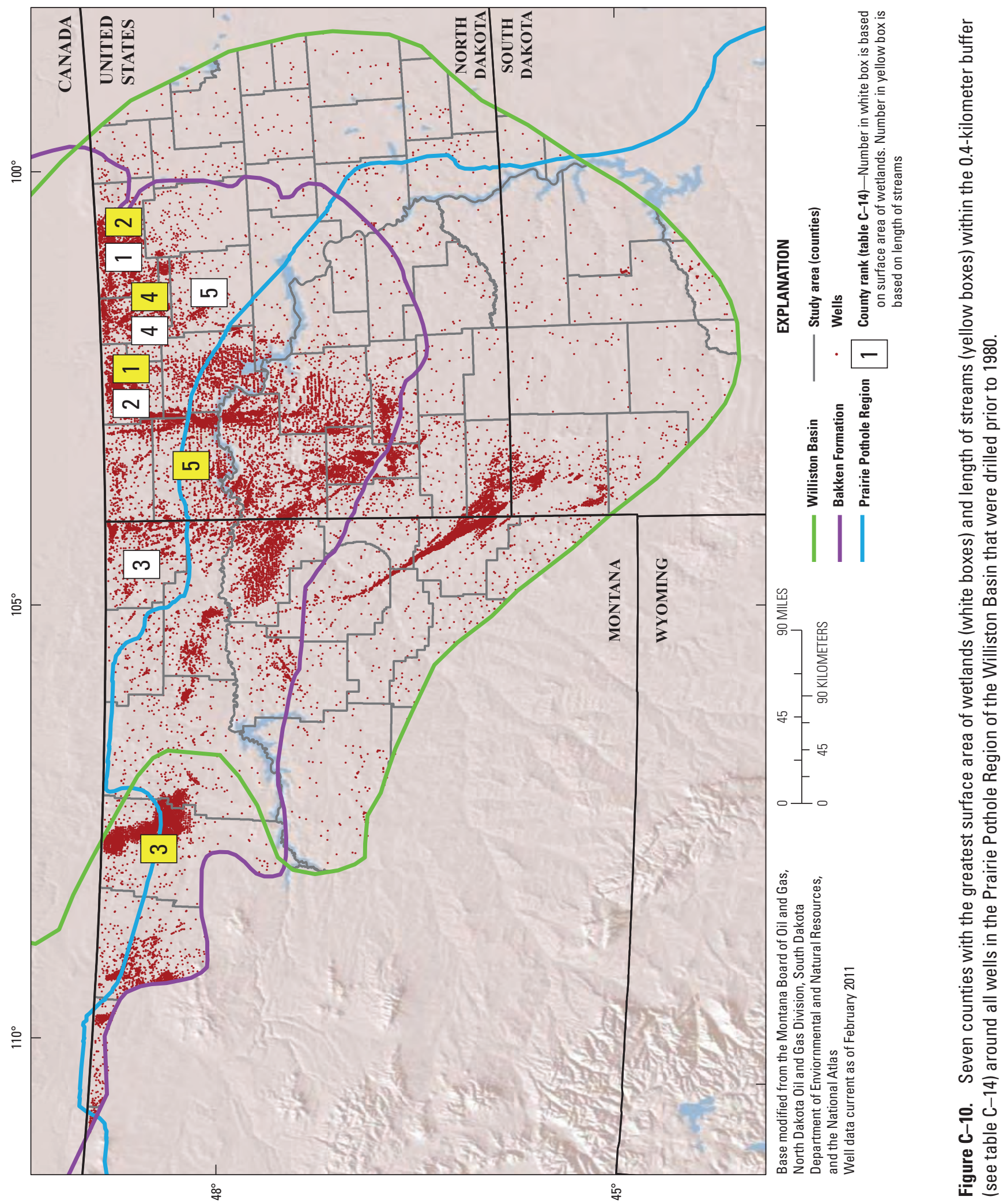




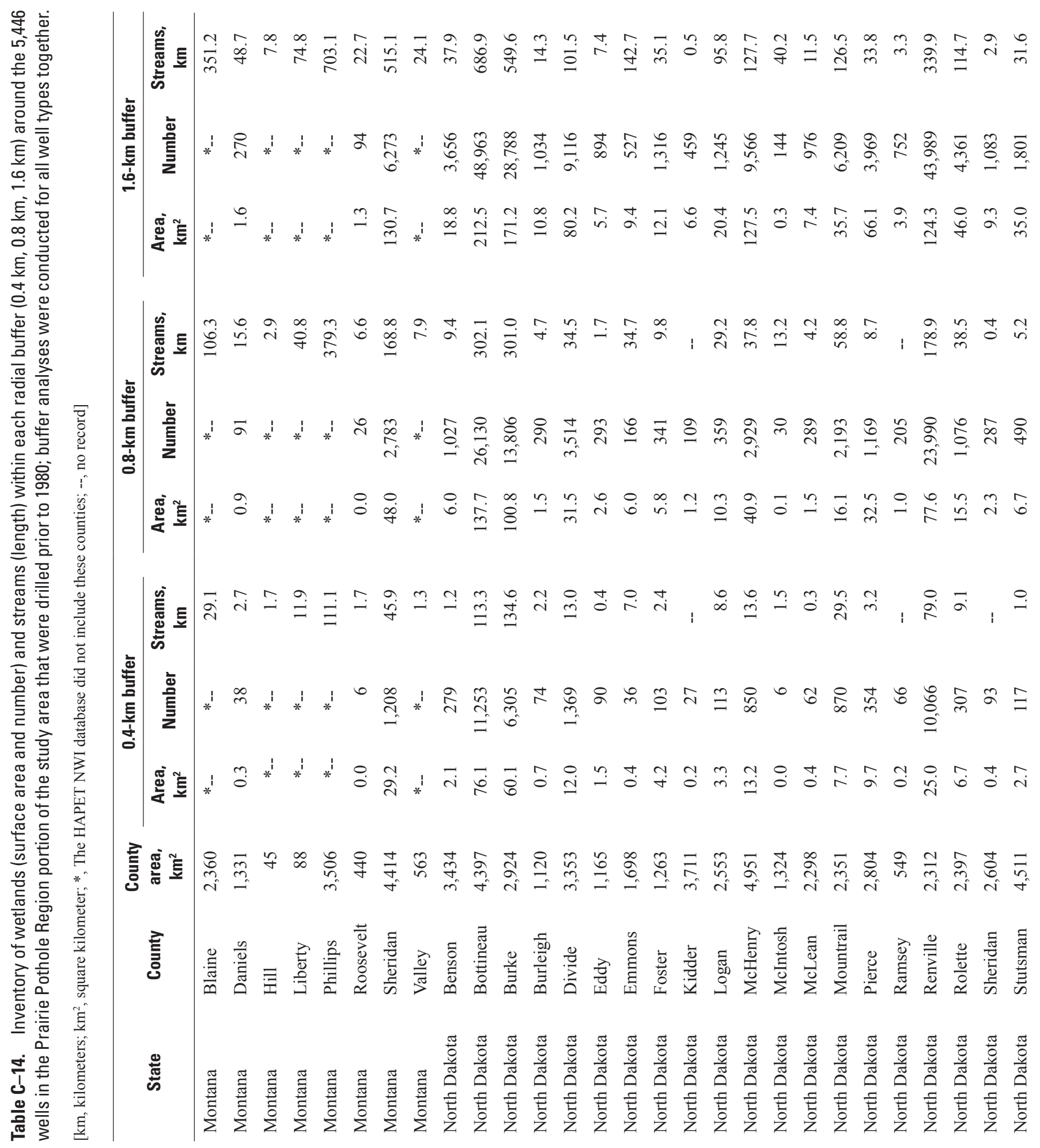




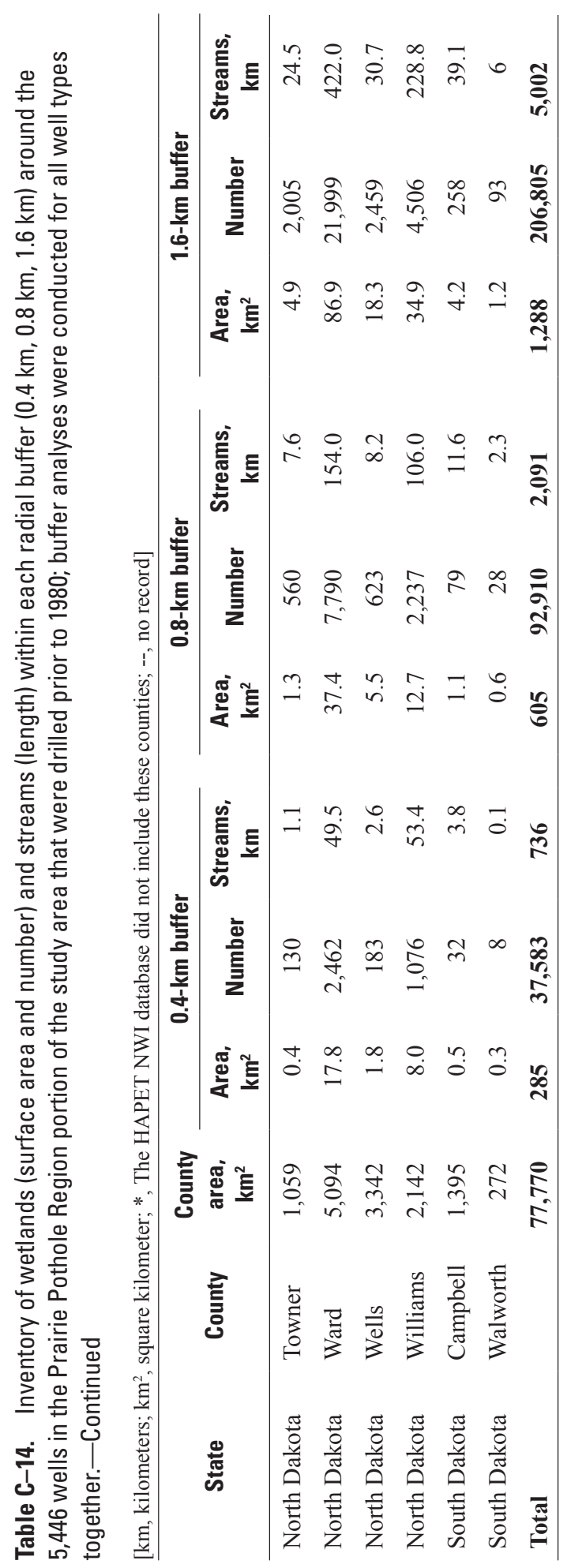




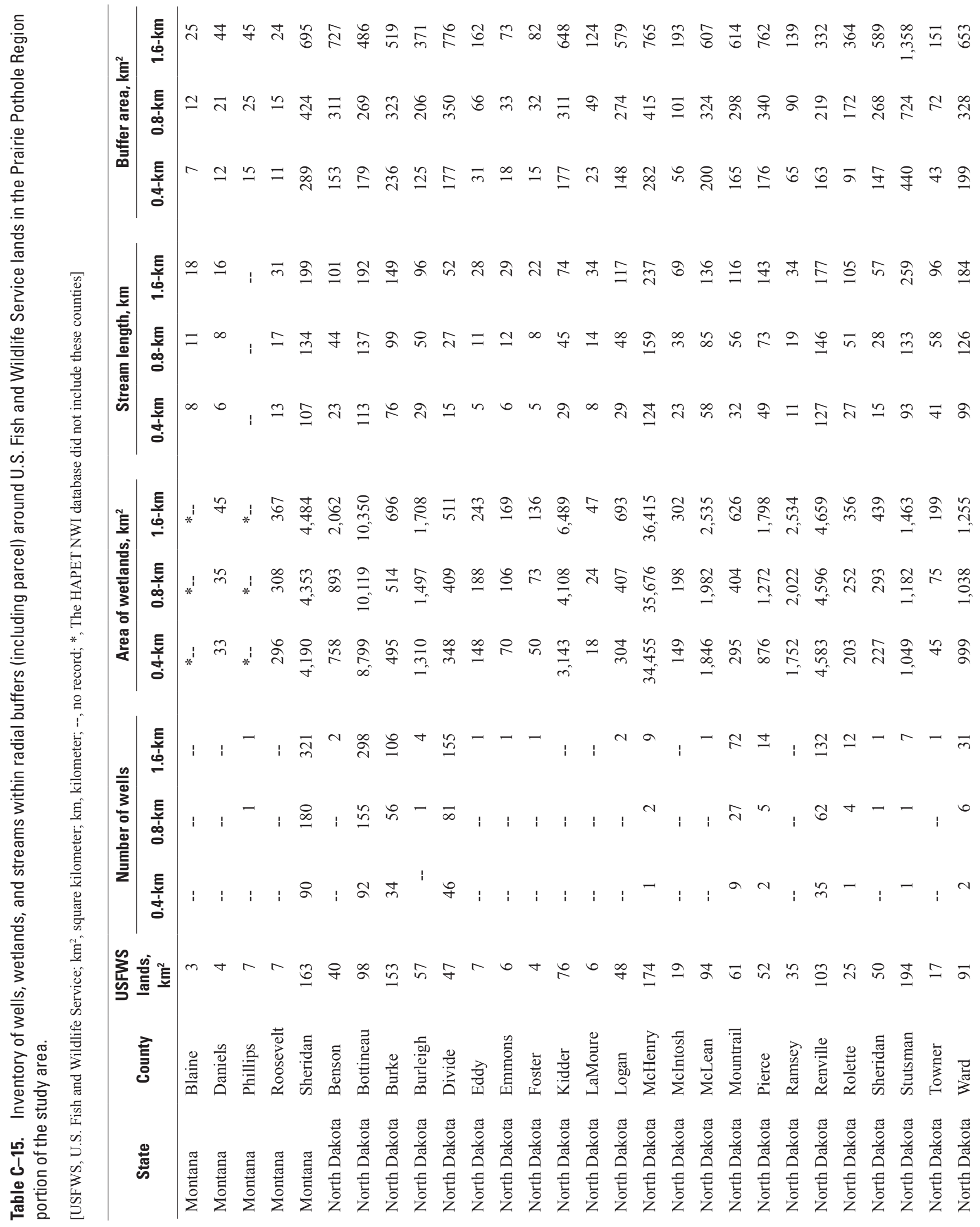




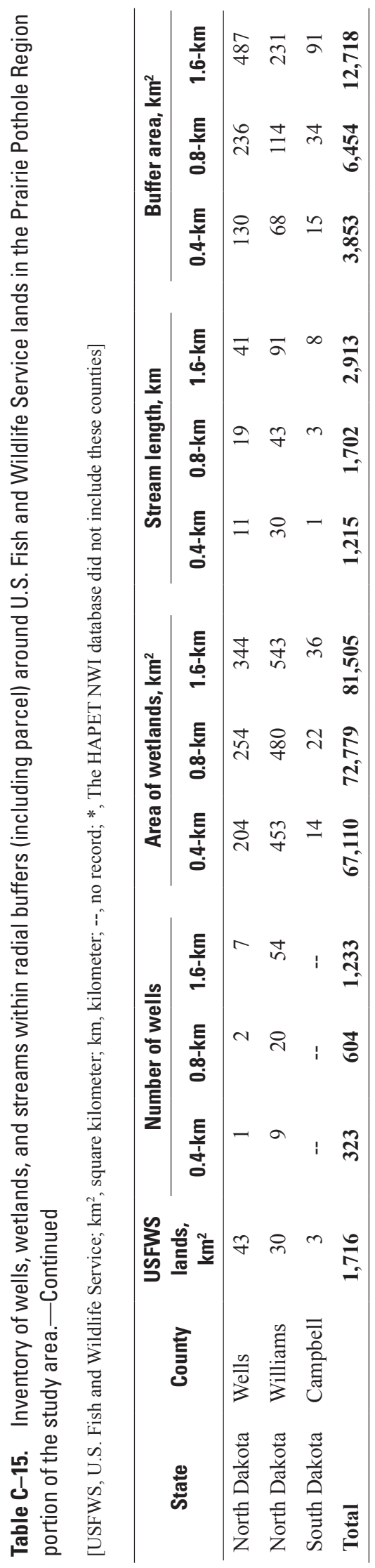



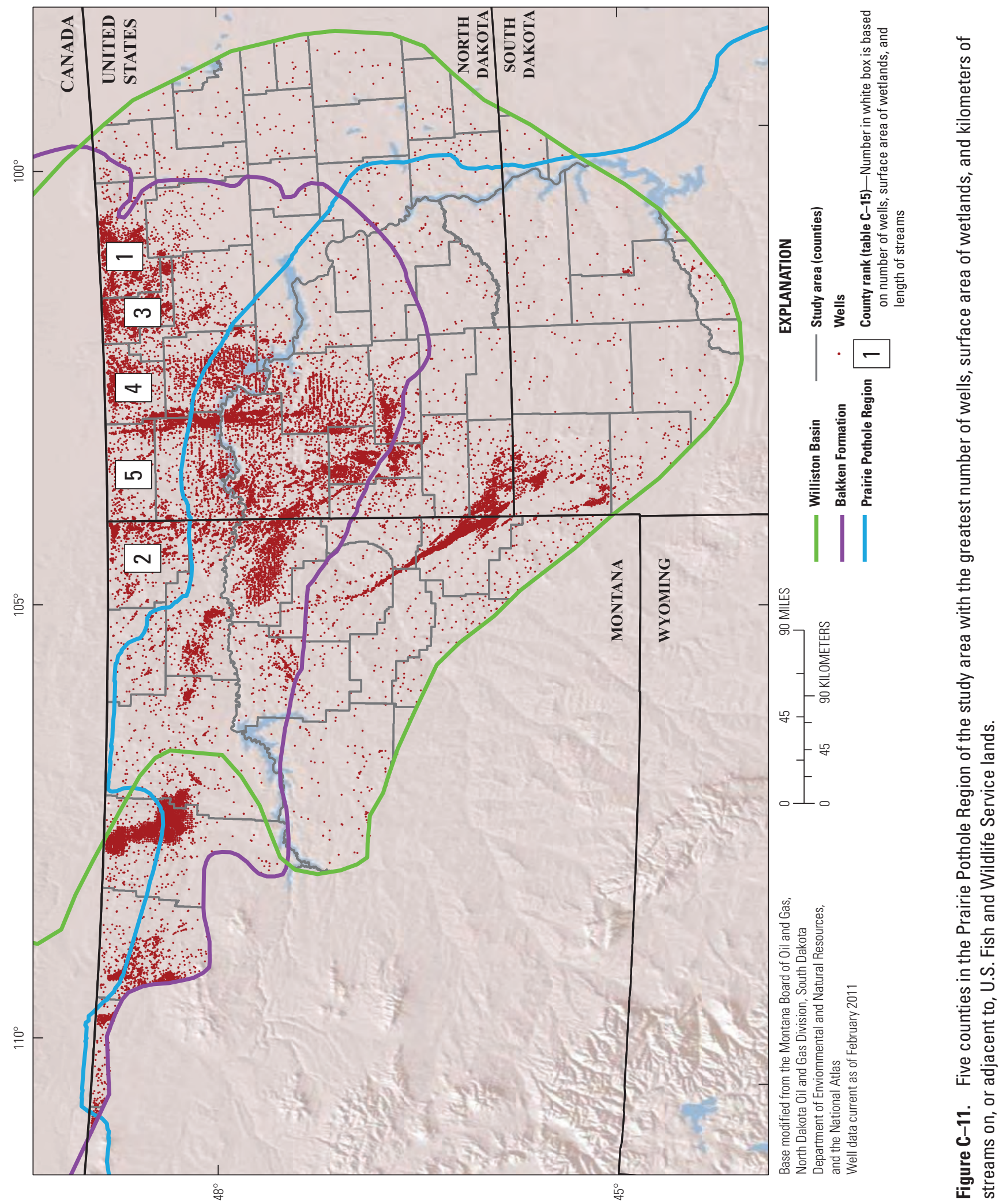
An overall depiction of the Williston Basin identified the parts of western North Dakota and northeastern Montana as having the overall greatest extent of wells (fig. C-2). Drilling began in the region around 1900 , but a majority of the more than 31,000 wells (tables C-2, C-3) were drilled after 1950 (figs. $\mathrm{C}-3, \mathrm{C}-4$ ). Peak production periods are related to factors such as the price of oil and advancement of modern drilling technologies of horizontal drilling and hydraulic fracturing. Most of the recent activity has taken place in western North Dakota and is associated with horizontal drilling that targets oil from the Bakken and Three Forks Formations. Of the nearly 3,000 wells drilled in the study area from 2008 to 2011 , nearly 70 percent were classified as oil producing and more than 90 percent of these oil wells were drilled in North Dakota. The recent upward trend in activity (fig. C-3) is predicted to continue as technology and oil prices have made it economically viable to obtain oil from vast reserves associated with the Bakken and other deep geologic formations (Gaswirth and others, 2013). In fact, State and industry officials from North Dakota predict that up to 2,000 wells per year could be drilled in the State for the foreseeable future.

Various spatial evaluations were performed with the purpose of identifying counties with the greatest likelihood of containing brine-contaminated aquatic resources. Within the overall U.S. part of the Williston Basin, counties located in the core area of oil- and gas-related activities in western North Dakota (fig. C-2) were distinguished on the basis of total number and density of wells, surface area and density of wetlands, and length and density of streams; however, Phillips and Valley Counties, two of the larger counties in the western PPR of Montana, also were singled out when only total number was considered, and the relatively small Bowman County in southwestern North Dakota was singled out based on mean density of wells, wetlands, and streams (table C-8, fig. C-8). Evaluation of counties in this manner provides a general spatial characterization of a large region while simultaneously considering multiple variables (wells, wetlands, streams). This approach, however, does not consider the distribution of wells and aquatic resources and may not always be the most appropriate for assessing the potential for contamination. For example, the five counties identified in figure $\mathrm{C}-8$ all ranked relatively high for wells and had intermediate ranks for wetlands and streams (table $\mathrm{C}-8$ ); thus, counties containing high numbers of wells do not necessarily contain a high density of aquatic resources, and the likelihood of containing brine-contaminated aquatic resources may not be strongly related to mean ranks such as those presented in table $\mathrm{C}-8$.

Therefore, a proximity analysis was performed to identify not only areas containing relatively high amounts of wells and aquatic resources but also areas with the most resources proximate to wells. Results of the PPR proximity analysis indicated that there are considerable aquatic resources proximate to wells that may be affected by brines because of subsurface migration from reserve pits or various types of surface spills. In fact, over $500 \mathrm{~km}^{2}$ of wetlands, $1,300 \mathrm{~km}$ of streams, and 5 $\mathrm{km}^{2}$ of critical habitat were identified within a $0.4-\mathrm{km}$ buffer of the 10,361 wells in the PPR. These numbers rose considerably as the buffer distances expanded to $1.6 \mathrm{~km}$, with the area of wetlands and length of streams increasing approximately 4 to 5 times, and area critical habitat increased by roughly 16 times (tables C-9, C-10). Similar to the regional characterization, counties were described based only on wetlands and streams within $0.4 \mathrm{~km}$ of wells to identify the counties in the PPR with the greatest likelihood of containing brine-affected aquatic systems (table $\mathrm{C}-11$, fig. $\mathrm{C}-9$ ). The counties in northwestern North Dakota and northeastern Montana with the greatest part of their land area within the PPR ranked highest for aquatic resources adjacent to wells.

To identify areas associated with the older, unlined reserve pits, a proximity analysis was performed using only wells drilled prior to 1980. Slightly more than one-half of the wells in the PPR were drilled prior to 1980, but the amount of aquatic resources proximate to wells was still considerable with nearly $300 \mathrm{~km}^{2}$ of wetlands, more than $700 \mathrm{~km}$ of streams, and $2 \mathrm{~km}^{2}$ of critical habitat within the $0.4-\mathrm{km}$ buffer. Upward trends in the amount of aquatic resources from the $0.4-\mathrm{km}$ buffer to the $1.6-\mathrm{km}$ buffer were consistent with the analysis of all wells. The area of wetlands and length of streams increased approximately 5 to 7 times, and the critical habitat increased by 19 times (tables $\mathrm{C}-12, \mathrm{C}-13$ ). County ranks based on aquatic resources within the $0.4-\mathrm{km}$ buffer around the pre-1980 wells (table C-14) were also similar to those for all wells, although distribution of the high-ranking counties shifted slightly (figs. C-9, C-10).

The USFWS administers more than $1,700 \mathrm{~km}^{2}$ of land in the PPR part of the study area. Much of these lands consist of NWRs and WPAs that include a great number and variety of wetland types. Pothole wetlands have the greatest ecological value when they exist as complexes consisting of a variety of habitat types such as multiple wetland classes nested within grasslands. Thus, the composition and ecological condition of the lands surrounding these refuges and production areas can play an important role in the relative quality of the habitats. Therefore, areas with the greatest potential for a reduction in the value of ecosystem services provided by these lands were identified by calculating the number of wells and amount of aquatic resources on or near lands managed by the USFWS (table $\mathrm{C}-15$, fig. $\mathrm{C}-11$ ). This assessment indicated that there was a substantial amount of aquatic resources associated with USFWS lands (table C-15), and there was considerable potential for brine contamination from nearby oil and gas production activity. In fact, there were more than 300 wells within the $0.4-\mathrm{km}$ buffer around USFWS lands and more than 1,200 wells within the $1.6-\mathrm{km}$ buffer (table $\mathrm{C}-15$ ). This spatial characterization identified the counties with high well densities in the northernmost parts of the PPR of the study area as having the greatest potential for containing affected aquatic resources on USFWS lands (fig. C-11). Further, a large number of wetland and grassland easements were located in the vicinity of oil and gas wells in these counties. Although these are privately owned lands, the USFWS provided financial compensation in exchange for conservation benefits associated 
with limiting agricultural disturbance (for example, draining, filling, burning) to these habitats. This simple proximity analysis suggests that there is potential for a reduction in the ecological integrity of these sites beyond those expected because of agricultural disturbances.

The regional spatial assessment and PPR proximity analyses identified areas with a greater likelihood of containing brine-contaminated aquatic resources on the basis of their spatial relation to oil and gas wells. These assessments are based on the assumption that there is high likelihood brines will migrate from a point source to wetlands, streams, and groundwater. This belief is supported by studies demonstrating brine contamination and migration (Reiten, 1991; Reiten and Tischmak, 1993; Thamke and Craigg, 1997), and the findings of this study that the majority of the region's wells were associated with soils considered well-drained or excessively drained (table C-6). Although the soil drainage class does not specifically describe permeability, it is a suitable surrogate that allows for determination of a relative rate that water typically moves through a given soil. The soil drainage classes associated with approximately 95 percent of wells indicate that the physical properties of the soils are conducive to the migration of brines if there was a spill or leak and the hydraulic gradient was sufficient (table $\mathrm{C}-6$ ). The rate of movement, however, is highly variable and governed by several factors including soil porosity, precipitation, and hydraulic conductivity.

\section{Data Limitations}

Assessments evaluating potential for brine contamination to aquatic resources in the Williston Basin ideally would include locations of buried reserve pits, likely groundwater flow paths, site-specific geologic data, and information pertaining to the probability and locations of brine leaks or spills. At this time, data pertaining to the location or status of active or abandoned reserve or evaporation pits do not exist because detailed records concerning these features are not maintained by State regulatory agencies. Further, funds were unavailable to purchase regional elevation data with sufficient resolution to relate elevations of wells and aquatic resources and estimate potential groundwater flow paths in the low-relief landscape. Lastly, it was difficult to determine site-level geology (for example, glacial till or outwash) using the existing coarse spatial data. The addition of high-resolution databases would allow for refinement of the analyses, downscaling to the individual site level, and for exploration of a decision-support tool for use in placing wells where they will have the least potential to affect aquatic resources.

\section{Ecological Significance of Brine Contamination}

The focus, thus far, has been on identifying areas with a greater likelihood of containing brine-contaminated aquatic resources, but the underlying question is "What are the effects of brine contamination to the biotic communities associated with these systems?" The primary goals of this overall project were to spatially describe the relations between oil and gas production activities and aquatic resources and to characterize brine migration and contamination at specific sites; therefore, direct effects of brines to aquatic ecosystems and biotic communities were not specifically assessed. Nonetheless, there is a significant amount of scientific literature describing relations between biotic communities and salinity (Stewart and Kantrud, 1972; Swanson and others, 1984; Hammer and others, 1990; Wollheim and Lovvorn, 1995; Baskin and Baskin, 1998; Gleason and others, 2009). Additions of highly saline brines can raise salinity levels as well as alter the composition of salts, and both of these factors have been shown to affect biota (Swanson and others, 1984; Mitcham and Wobeser, 1988; Zalizniak and others, 2006). Baskin and Baskin (1998) showed that concentrations of sodium chloride ranging from about 3,000 to $100,000 \mathrm{mg} / \mathrm{L}$ reduced germination success of many salt tolerant plants to about 10 percent. Further, salinity has been related to plant and invertebrate community composition (Stewart and Kantrud, 1972; Hammer and Heseltine, 1988; Hammer and others, 1990; Gleason and others, 2009), and saline waters have been shown to cause mortality and affect growth and development of ducklings (Swanson and others, 1984; Mitcham and Wobeser, 1988; Moorman and others, 1991; DeVink and others, 2005). In addition, high concentrations of sodium, which is characteristic of Williston Basin brines, can affect soil structure. However, the effects of brine contamination to individual biotic communities would be highly variable depending on factors such as the relative amount of brine introduced to the system, background salt concentration in the system, the composition of the biota, and the relation between the wetland and groundwater.

\section{Future Research}

Numerous scientific investigations, including chapter $\mathrm{B}$ of this report, have established that produced brines have contaminated soils, surface waters, and groundwater in the Williston Basin (Lang and Doll, 1983; Beal and others, 1987; Murphy and others, 1988; Payne and Reiten, 1991; Reiten and Tischmak, 1993, Thamke and Craigg, 1997). This chapter identifies areas with a greater likelihood of containing brine-contaminated aquatic systems by describing the spatial relations among wells, wetlands, and streams. Nonetheless, significant information gaps remain. These gaps include: characterization of the chemistry of surface waters to define natural levels or current baselines, evaluations of the regional extent and magnitude of contamination, effect of brines to biotic communities, and assessments of mitigation techniques. Requirements for spatial data include regional high-resolution elevation and geologic layers and reserve or evaporation pit locations. Information pertaining to the characteristics and the extent of spills also would be valuable. 


\section{References}

Baskin, C.C., and Baskin, J.M., 1998, Seeds-Ecology, biogeography, and evolution of dormancy and germination: San Diego, Calif., Academic Press, 666 p.

Beal, W.A., Murphy, E.C., and Kehew, A.E., 1987, Migration of contaminants from buried oil-and-gas drilling fluids within the glacial sediments of north-central North Dakota: North Dakota Geological Survey, Report of Investigation No. 86,43 p.

DeVink, J-M.A., Gilchrist, H.G., and Diamond, A.W., 2005, Effects of water salinity on growth and survival of common eider (Somateria mollissima) duckings: The Auk, v. 122, p. 523-529.

Gaswirth, S.B., Marra, K.R., Cook, T.A, Charpentier, R.R., Gautier, D.L., Higley, D.K., Klett, T.R., Lewan, M.D., Lillis, P.G., Schenk, C.J., Tennyson, M.E., and Whidden, K.J., 2013, Assessment of undiscovered oil resources in the Bakken and Three Forks Formations, Williston Basin Province, Montana, North Dakota, and South Dakota, 2013: U.S. Geological Survey Fact Sheet 2013-3013, 4 p. (Also available at http://pubs.usgs.gov/fs/2013/3013/.)

Gleason, R.A., Tangen, B.A., Laubhan, M.K., Finocchiaro, R.G., and Stamm, J.F., 2009, Literature review and database of relations between salinity and aquatic biota-Applications to Bowdoin National Wildlife Refuge, Montana: U.S. Geological Survey Scientific Investigations Report 2009$5098,76 \mathrm{p}$.

Hammer, U.T., and Heseltine, J.M., 1988, Aquatic macrophytes in saline lakes of the Canadian prairies: Hydrobiologia, v. 158, p. 101-116.

Hammer, U.T., Sheard, J.S., and Kranabetter, J., 1990, Distribution and abundance of littoral benthic fauna in Canadian prairie saline lakes: Hydrobiologia, v. 197, p. 173-192.

Lang, K.J., and Doll, E.C., 1983, Salt distribution around a buried brine disposal pit: North Dakota State University, Land Reclamation Research Center, Technical Report No. $1,10 \mathrm{p}$.

Mitcham, S.A., and Wobeser, G., 1988, Effects of sodium and magnesium sulfate in drinking water on mallard ducklings: Journal of Wildlife Diseases, v. 24, p. 30-44.

Moorman, A.M., Moorman, T.E., Baldassarre, G.A., and Richard, D.M., 1991, Effects of saline water on growth and survival of mottled duck ducklings in Louisiana: Journal of Wildlife Management, v. 55, p. 471-476.

Murphy, E.C., Kehew, A.E., Groenewold, G.H., and Beal, W.A., 1988, Leachate generated by an oil-and-gas brine pond site in North Dakota: Ground Water, v. 26, p. 31-38.
North Dakota Industrial Commission, 2011, North Dakota drilling and production statistics: Department of Mineral Resources, Oil and Gas Division, accessed March 1, 2011, at https://www.dmr.nd.gov/oilgas/stats/statisticsvw.asp.

Openshaw, S., 1984, The modifiable areal unit problem, concepts and techniques in modern geography 38 : Norwich, England, Geo Books, 41 p.

Payne, S.M., and Reiten, J.C., 1991, Impacts of oil field wastes on soil and ground water in Richland County, Montana, Part III-Hydrogeologic conditions and ground water quality at an oil well reserve pit, Richland County, Montana: Montana Bureau of Mines and Geology Open-File Report 237-C, $120 \mathrm{p}$.

Reiten, J.C., 1991, Impacts of oil field wastes on soil and ground water in Richland County, Montana, Part II-Contaminant movement below oil field drilling mud disposal pits, Fairview, Montana: Montana Bureau of Mines and Geology, Open-File Report 237-B, 115 p.

Reiten, J.C., and Tischmak, T., 1993, Appraisal of oil field brine contamination in shallow ground water and surface water, eastern Sheridan County, Montana: Billings, Mont., Montana Bureau of Mines and Geology Open-File 260, 296 p., 2 sheets.

Soller, D.R., and Packard, P.H., 1998, Digital representation of a map showing the thickness and character of Quarternary sediments in the glaciated Untied States east of the Rocky Mountains: U.S. Geological Survey Data Series 38.

Stewart, R.E., and Kantrud, H.A., 1972, Vegetation of prairie potholes, North Dakota, in relation to quality of water and other environmental factors: U.S. Geological Survey Professional Paper 585-D, 36 p.

Stoeser, D.B., Green, G.N., Morath, L.C., Heran, W.D., Wilson, A.B., Moore, D.W., and Van Gosen, B.S., 2007, Preliminary integrated geologic map databases for the United States: Central States: Montana, Wyoming, Colorado, New Mexico, North Dakota, South Dakota, Nebraska, Kansas, Oklahoma, Texas, Iowa, Missouri, Arkansas, and Louisiana: U.S. Geological Survey Open-File Report 2005-1351.

Swanson, G.A., Adomaitis, V.A., Lee, F.B., Serie, J.R., and Shoesmith, J.A., 1984, Limnological conditions influencing duckling use of saline lakes in south-central North Dakota: Journal of Wildlife Management, v. 48, p. 340-349.

Thamke, J.N., and Craigg, S.D., 1997, Saline-water contamination in Quaternary deposits and the Poplar River, East Poplar oil field, northeastern Montana: U.S. Geological Survey Water-Resources Investigations Report 97-4000, 37 p. 
U.S. Department of Agriculture, 2010, Description of Soil Survey Geographis (SSURGO) database: Natural Resources Conservation Service, assessed October 1, 2010, at http:// www.soils.usda.gov/survey/geography/ssurgo/description. html.

U.S. Fish and Wildlife Service, 2010, National Wetlands Inventory: U.S. Fish and Wildlife Service, assessed May 1, 2010, at http://www.fws.gov/wetlands/.

U.S. Geological Survey, 2009, National hydrography dataset: U.S. Geological Survey, assessed November 1, 2009, at http://nhd.usgs.gov/.

Veil, J.A., Puder, M.G., Elcock, D., Redweik, R.J., Jr., 2004, A white paper describing produced water from production of crude oil, natural gas, and coal bed methane: Prepared for the U.S. Department of Energy, National Energy Technology Laboratory by Argonne National Laboratory, Argonne, Ill., $79 \mathrm{p}$.
Wanty, R.B., 1997, USGS research on saline waters co-produced with energy resources: U.S. Geological Survey Fact Sheet 003-97, 3 p.

Wollheim, W.M., and Lovvorn, J.R., 1995, Salinity effects on macroinvertebrate assemblages and waterbird food webs in shallow lakes of the Wyoming High Plains: Hydrobiologia, v. 310, p. 207-223.

Zalizniak, L., Kefford, B.J., and Nugegoda, D., 2006, Is all salinity the same? I. The effect of ionic compositions on the salinity tolerance of five species of freshwater invertebrates: Marine and Freshwater Research, v. 57, p. 75-82. 

Appendix 
Appendix C-1. Well classifications for Montana, North Dakota, and South Dakota and the overall well type used for this study.

[ $\geq$, greater than or equal to; $\leq$, less than or equal to; >, greater than]

\begin{tabular}{|c|c|c|}
\hline State & State well classification & Well type \\
\hline Montana & Dry hole-abandoned & Dry hole \\
\hline Montana & Dry hole-abandoned-unapproved & Dry hole \\
\hline Montana & Dry hole-completed & Dry hole \\
\hline Montana & Dry hole-plugged and abandoned-approved & Dry hole \\
\hline Montana & Dry hole-temporarily abandoned & Dry hole \\
\hline Montana & Dry hole-unknown & Dry hole \\
\hline Montana & Dry hole-water well, released & Dry hole \\
\hline Montana & Coalbed methane-plugged and abandoned-approved & Gas \\
\hline Montana & Coalbed methane-producing & Gas \\
\hline Montana & Coalbed methane-shut-in & Gas \\
\hline Montana & Coalbed methane-spudded & Gas \\
\hline Montana & Gas-abandoned & Gas \\
\hline Montana & Gas-abandoned-unapproved & Gas \\
\hline Montana & Gas-completed & Gas \\
\hline Montana & Gas-domestic & Gas \\
\hline Montana & Gas-plugged and abandoned-approved & Gas \\
\hline Montana & Gas-producing & Gas \\
\hline Montana & Gas-shut-in & Gas \\
\hline Montana & Gas-spudded & Gas \\
\hline Montana & Gas-temporarily abandoned & Gas \\
\hline Montana & Gas-unknown & Gas \\
\hline Montana & Gas-water well, released & Gas \\
\hline Montana & Gas storage-completed & Gas \\
\hline Montana & Gas storage-expired permit & Gas \\
\hline Montana & Gas storage-plugged and abandoned-approved & Gas \\
\hline Montana & Dry hole-permitted injection well & Injection \\
\hline Montana & Gas-permitted injection well & Injection \\
\hline Montana & Injection-disposal-abandoned-unapproved & Injection \\
\hline Montana & Injection-disposal-active injection & Injection \\
\hline Montana & Injection-disposal-plugged and abandoned-approved & Injection \\
\hline Montana & Injection-disposal-permitted injection well & Injection \\
\hline Montana & Injection-disposal-producing & Injection \\
\hline Montana & Injection-disposal-spudded & Injection \\
\hline Montana & Injection, enhanced oil recovery-abandoned-unapproved & Injection \\
\hline Montana & Injection, enhanced oil recovery-active injection & Injection \\
\hline Montana & Injection, enhanced oil recovery-plugged and abandoned-approved & Injection \\
\hline Montana & Injection, enhanced oil recovery-permitted injection well & Injection \\
\hline Montana & Injection, enhanced oil recovery-producing & Injection \\
\hline Montana & Injection, enhanced oil recovery-shut-in & Injection \\
\hline Montana & Injection, enhanced oil recovery-temporarily abandoned & Injection \\
\hline
\end{tabular}


Appendix C-1. Well classifications for Montana, North Dakota, and South Dakota and the overall well type used for this study.-Continued

$[\geq$, greater than or equal to; $\leq$, less than or equal to; $>$, greater than]

\begin{tabular}{|c|c|c|}
\hline State & State well classification & Well type \\
\hline Montana & Injection, enhanced oil recovery-water well, released & Injection \\
\hline Montana & Injection, Indian lands-abandoned-unapproved & Injection \\
\hline Montana & Injection, Indian lands-active injection & Injection \\
\hline Montana & Injection, Indian lands-completed & Injection \\
\hline Montana & Injection, Indian lands-plugged and abandoned-approved & Injection \\
\hline Montana & Injection, Indian lands-shut-in & Injection \\
\hline Montana & Injection, Indian lands-unknown & Injection \\
\hline Montana & Oil-permitted injection well & Injection \\
\hline Montana & Monitor/observation-abandoned-unapproved & Monitor/observation \\
\hline Montana & Monitor/observation-completed & Monitor/observation \\
\hline Montana & Monitor/observation-plugged and abandoned-approved & Monitor/observation \\
\hline Montana & Monitor/observation-shut-in & Monitor/observation \\
\hline Montana & Monitor/observation-temporarily abandoned & Monitor/observation \\
\hline Montana & Coalbed methane-expired permit & Never drilled \\
\hline Montana & Coalbed methane-permit to drill & Never drilled \\
\hline Montana & Expired location-expired permit & Never drilled \\
\hline Montana & Gas-expired permit & Never drilled \\
\hline Montana & Gas-expired, not released & Never drilled \\
\hline Montana & Gas-permit to drill & Never drilled \\
\hline Montana & Injection-disposal-expired permit & Never drilled \\
\hline Montana & Injection-disposal-permit to drill & Never drilled \\
\hline Montana & Injection, enhanced oil recovery-expired permit & Never drilled \\
\hline Montana & Oil-expired permit & Never drilled \\
\hline Montana & Oil-expired, not released & Never drilled \\
\hline Montana & Oil-permit to drill & Never drilled \\
\hline Montana & Water source-expired permit & Never drilled \\
\hline Montana & Oil-abandoned & Oil \\
\hline Montana & Oil-abandoned-unapproved & Oil \\
\hline Montana & Oil-completed & Oil \\
\hline Montana & Oil-plugged and abandoned-approved & Oil \\
\hline Montana & Oil-producing & Oil \\
\hline Montana & Oil-shut-in & Oil \\
\hline Montana & Oil-spudded & Oil \\
\hline Montana & Oil-temporarily abandoned & Oil \\
\hline Montana & Oil-unknown & Oil \\
\hline Montana & Oil-water well, released & Oil \\
\hline Montana & Stratigraphic test-completed & Stratigraphic test \\
\hline Montana & Stratigraphic test-plugged and abandoned-approved & Stratigraphic test \\
\hline Montana & Stratigraphic test-water well, released & Stratigraphic test \\
\hline Montana & Unknown-plugged and abandoned-approved & Unknown/confidential \\
\hline
\end{tabular}


Appendix C-1. Well classifications for Montana, North Dakota, and South Dakota and the overall well type used for this study.-Continued

$[\geq$, greater than or equal to; $\leq$, less than or equal to; >, greater than]

\begin{tabular}{|c|c|c|}
\hline State & State well classification & Well type \\
\hline Montana & Unknown & Unknown/confidential \\
\hline Montana & Domestic water-completed & Water \\
\hline Montana & Domestic water-plugged and abandoned-approved & Water \\
\hline Montana & Water source-abandoned-unapproved & Water \\
\hline Montana & Water source-completed & Water \\
\hline Montana & Water source-plugged and abandoned-approved & Water \\
\hline Montana & Water source-producing & Water \\
\hline Montana & Water source-shut-in & Water \\
\hline Montana & Water source-temporarily abandoned & Water \\
\hline Montana & Water source-unknown & Water \\
\hline Montana & Water source-water well, released & Water \\
\hline North Dakota & Confidential & Confidential \\
\hline North Dakota & Coalbed methane, dry hole & Dry hole \\
\hline North Dakota & Gas condensate, dry hole & Dry hole \\
\hline North Dakota & Dry gas, dry hole & Dry hole \\
\hline North Dakota & Oil and gas, dry hole & Dry hole \\
\hline North Dakota & Stratigraphic test, dry hole & Dry hole \\
\hline North Dakota & Coalbed methane, active & Gas \\
\hline North Dakota & Coalbed methane, inactive (shut-in $\geq 3$ and $\leq 12$ months) & Gas \\
\hline North Dakota & Gas condensate, active & Gas \\
\hline North Dakota & Gas condensate, abandoned (shut-in >12 months) & Gas \\
\hline North Dakota & Gas condensate, inactive (shut-in $\geq 3$ and $\leq 12$ months) & Gas \\
\hline North Dakota & Gas condensate, plugged and abandoned (shut-in $>12$ months) & Gas \\
\hline North Dakota & Gas condensate, temporarily abandoned (shut-in $>12$ months) & Gas \\
\hline North Dakota & Dry gas, active & Gas \\
\hline North Dakota & Dry gas, drilling & Gas \\
\hline North Dakota & Dry gas, expired permit & Gas \\
\hline North Dakota & Dry gas, inactive (shut-in $\geq 3$ and $\leq 12$ months) & Gas \\
\hline North Dakota & Dry gas, plugged and abandoned (shut-in $>12$ months) & Gas \\
\hline North Dakota & Oil and gas well, active & Gas \\
\hline North Dakota & Oil and gas well, abandoned (shut-in >12 months) & Gas \\
\hline North Dakota & Oil and gas well, plugged and abandoned (shut-in $>12$ months) & Gas \\
\hline North Dakota & Gas injection, inactive (shut-in $\geq 3$ and $\leq 12$ months) & Gas \\
\hline North Dakota & Gas stratigraphic test storage, plugged and abandoned (shut-in $>12$ months) & Gas \\
\hline North Dakota & Acid gas disposal, active & Injection \\
\hline North Dakota & Acid gas disposal, inactive (shut-in $\geq 3$ and $\leq 12$ months) & Injection \\
\hline North Dakota & Air injection, abandoned (shut-in >12 months) & Injection \\
\hline North Dakota & Air injection, inactive (shut-in $\geq 3$ and $\leq 12$ months) & Injection \\
\hline North Dakota & Air injection, plugged and abandoned (shut-in >12 months) & Injection \\
\hline North Dakota & Air injection, temporarily abandoned (shut-in $>12$ months) & Injection \\
\hline
\end{tabular}


Appendix C-1. Well classifications for Montana, North Dakota, and South Dakota and the overall well type used for this study.-Continued

$[\geq$, greater than or equal to; $\leq$, less than or equal to; >, greater than]

\begin{tabular}{|c|c|c|}
\hline State & State well classification & Well type \\
\hline North Dakota & Dump flood injector, active & Injection \\
\hline North Dakota & Dump flood injector, abandoned (shut-in >12 months) & Injection \\
\hline North Dakota & Dump flood injector, inactive (shut-in $\geq 3$ and $\leq 12$ months) & Injection \\
\hline North Dakota & Dump flood injector, plugged and abandoned (shut-in $>12$ months) & Injection \\
\hline North Dakota & Dump flood injector/producer, active & Injection \\
\hline North Dakota & Injector, producer, active & Injection \\
\hline North Dakota & Salt water disposal, active & Injection \\
\hline North Dakota & Salt water disposal, abandoned (shut-in $>12$ months) & Injection \\
\hline North Dakota & Salt water disposal, drilling & Injection \\
\hline North Dakota & Salt water disposal, dry hole & Injection \\
\hline North Dakota & Salt water disposal, inactive (shut-in $\geq 3$ and $\leq 12$ months) & Injection \\
\hline North Dakota & Salt water disposal, plugged and abandoned (shut-in $>12$ months) & Injection \\
\hline North Dakota & Salt water disposal, temporarily abandoned (shut-in $>12$ months) & Injection \\
\hline North Dakota & Water injection, active & Injection \\
\hline North Dakota & Water injection, abandoned (shut-in $>12$ months) & Injection \\
\hline North Dakota & Water injection, dry hole & Injection \\
\hline North Dakota & Water injection, inactive (shut-in $\geq 3$ and $\leq 12$ months) & Injection \\
\hline North Dakota & Water injection, plugged and abandoned (shut-in $>12$ months) & Injection \\
\hline North Dakota & Water injection, temporarily abandoned (shut-in $>12$ months) & Injection \\
\hline North Dakota & Water injection, temporarily abandoned (shut-in $>12$ months)-observation & Injection \\
\hline North Dakota & Dry gas, permitted location to drill & Never drilled \\
\hline North Dakota & Dry gas, permit now cancelled & Never drilled \\
\hline North Dakota & Oil and gas, expired permit & Never drilled \\
\hline North Dakota & Oil and gas permitted location to drill & Never drilled \\
\hline North Dakota & Oil and gas, permit now cancelled & Never drilled \\
\hline North Dakota & Salt water disposal permitted location to drill & Never drilled \\
\hline North Dakota & Salt water disposal, permit now cancelled & Never drilled \\
\hline North Dakota & Oil and gas, active & Oil \\
\hline North Dakota & Oil and gas, abandoned (shut-in $>12$ months) & Oil \\
\hline North Dakota & Oil and gas, drilling & Oil \\
\hline North Dakota & Oil and gas, inactive (shut-in $\geq 3$ and $\leq 12$ months) & Oil \\
\hline North Dakota & Oil and gas, plugged and abandoned (shut-in $>12$ months) & Oil \\
\hline North Dakota & Oil and gas, temporarily abandoned (shut-in $>12$ months) & Oil \\
\hline North Dakota & Oil and gas, temporarily abandoned (shut-in $>12$ months)-observation & Oil \\
\hline North Dakota & Stratigraphic test, active & Stratigraphic test \\
\hline North Dakota & Stratigraphic test, drilling & Stratigraphic test \\
\hline North Dakota & Water source, active & Water \\
\hline North Dakota & Water source, abandoned (shut-in $>12$ months) & Water \\
\hline North Dakota & Water source, drilling & Water \\
\hline North Dakota & Water source, inactive (shut-in $\geq 3$ and $\leq 12$ months) & Water \\
\hline
\end{tabular}


Appendix C-1. Well classifications for Montana, North Dakota, and South Dakota and the overall well type used for this study.-Continued

$[\geq$, greater than or equal to; $\leq$, less than or equal to; >, greater than]

\begin{tabular}{|c|c|c|}
\hline State & State well classification & Well type \\
\hline North Dakota & Water source, plugged and abandoned (shut-in $>12$ months) & Water \\
\hline North Dakota & Water source, temporarily abandoned (shut-in $>12$ months) & Water \\
\hline South Dakota & Dry hole-dry hole fee land-plugged and abandoned & Dry hole \\
\hline South Dakota & Dry hole-dry hole tribal land-plugged and abandoned & Dry hole \\
\hline South Dakota & Dry hole-dry hole tribal land-temporarily abandoned & Dry hole \\
\hline South Dakota & Dry hole-dry hole-converted & Dry hole \\
\hline South Dakota & Dry hole-dry hole-plugged and abandoned & Dry hole \\
\hline South Dakota & Dry hole-dry hole fee land-converted & Dry hole \\
\hline South Dakota & Dry hole-dry hole gas show-plugged and abandoned & Dry hole \\
\hline South Dakota & Dry hole-gas-plugged and abandoned & Dry hole \\
\hline South Dakota & Dry hole-gas show-plugged and abandoned & Dry hole \\
\hline South Dakota & Dry hole-horizontal permit-plugged and abandoned & Dry hole \\
\hline South Dakota & Dry hole-horizontal-plugged and abandoned & Dry hole \\
\hline South Dakota & Dry hole-oil-plugged and abandoned & Dry hole \\
\hline South Dakota & Dry hole-oil show-plugged and abandoned & Dry hole \\
\hline South Dakota & Dry hole-water well-converted & Dry hole \\
\hline South Dakota & Dry hole-water well-plugged and abandoned & Dry hole \\
\hline South Dakota & Gas-dry hole-plugged and abandoned & Dry hole \\
\hline South Dakota & Oil-dry hole fee land-plugged and abandoned & Dry hole \\
\hline South Dakota & Oil-dry hole-plugged and abandoned & Dry hole \\
\hline South Dakota & Gas-gas-converted & Gas \\
\hline South Dakota & Gas-gas-new drill & Gas \\
\hline South Dakota & Gas-gas-new well & Gas \\
\hline South Dakota & Gas-gas-plugged and abandoned & Gas \\
\hline South Dakota & Gas-gas-private & Gas \\
\hline South Dakota & Gas-gas-private gas & Gas \\
\hline South Dakota & Gas-gas-producing & Gas \\
\hline South Dakota & Gas-gas-temporarily abandoned & Gas \\
\hline South Dakota & Gas-gas show-plugged and abandoned & Gas \\
\hline South Dakota & Gas-gas stripper-plugged and abandoned & Gas \\
\hline South Dakota & Gas-gas stripper-producing & Gas \\
\hline South Dakota & Gas-gas stripper-temporarily abandoned & Gas \\
\hline South Dakota & Gas-vertical reentry-temporarily abandoned & Gas \\
\hline South Dakota & Oil-water injection permit-producing & Injection \\
\hline South Dakota & Underground injection control-air-injecting & Injection \\
\hline South Dakota & Underground injection control-air-plugged and abandoned & Injection \\
\hline South Dakota & Underground injection control-air-reservoir monitoring well & Injection \\
\hline South Dakota & Underground injection control-air-temporarily abandoned & Injection \\
\hline South Dakota & Underground injection control-air horizontal-injecting & Injection \\
\hline South Dakota & Underground injection control-gas injection permit-plugged and abandoned & Injection \\
\hline
\end{tabular}


Appendix C-1. Well classifications for Montana, North Dakota, and South Dakota and the overall well type used for this study.-Continued

$[\geq$, greater than or equal to; $\leq$, less than or equal to; >, greater than]

\begin{tabular}{|c|c|c|}
\hline State & State well classification & Well type \\
\hline South Dakota & Underground injection control-horizontal water-injecting & Injection \\
\hline South Dakota & Underground injection control-horizontal water-injecting & Injection \\
\hline South Dakota & Underground injection control-horizontal water reentry-new well & Injection \\
\hline South Dakota & Underground injection control-salt water disposal well-injecting & Injection \\
\hline South Dakota & Underground injection control-salt water disposal well-plugged and abandoned & Injection \\
\hline South Dakota & Underground injection control-tribal land-plugged and abandoned & Injection \\
\hline South Dakota & Underground injection control-water horizontal-injecting & Injection \\
\hline South Dakota & Underground injection control-water horizontal-reentered & Injection \\
\hline South Dakota & Underground injection control-water injection-injecting & Injection \\
\hline South Dakota & Underground injection control-water injection-plugged and abandoned & Injection \\
\hline South Dakota & Underground injection control-water injection-reentered & Injection \\
\hline South Dakota & Underground injection control-water injection-temporarily abandoned & Injection \\
\hline South Dakota & Underground injection control--water well-converted & Injection \\
\hline South Dakota & Underground injection control-water well-producing & Injection \\
\hline South Dakota & Gas-never drilled & Never drilled \\
\hline South Dakota & Gas-new permit & Never drilled \\
\hline South Dakota & Never drilled-gas & Never drilled \\
\hline South Dakota & Never drilled-horizontaL & Never drilled \\
\hline South Dakota & Never drilled-horizontal reentry & Never drilled \\
\hline South Dakota & Never drilled-tribal land & Never drilled \\
\hline South Dakota & Never drilled & Never drilled \\
\hline South Dakota & Oil-horizontal-never drilled & Never drilled \\
\hline South Dakota & Oil-horizontal-new permit & Never drilled \\
\hline South Dakota & Oil-new permit & Never drilled \\
\hline South Dakota & Oil-air injection permit-producing & Oil \\
\hline South Dakota & Oil-air injection permit-reentered & Oil \\
\hline South Dakota & Oil-gas injection permit-producing & Oil \\
\hline South Dakota & Oil-horizontal-plugged and abandoned & Oil \\
\hline South Dakota & Oil-horizontal-producing & Oil \\
\hline South Dakota & Oil-horizontal-reentered & Oil \\
\hline South Dakota & Oil-horizontal-temporarily abandoned & Oil \\
\hline South Dakota & Oil-horizontal reentry-converted & Oil \\
\hline South Dakota & Oil-horizontal reentry-plugged and abandoned & Oil \\
\hline South Dakota & Oil-horizontal reentry-producing & Oil \\
\hline South Dakota & Oil-horizontal reentry-reentered & Oil \\
\hline South Dakota & Oil-horizontal reentry-temporarily abandoned & Oil \\
\hline South Dakota & Oil-converted & Oil \\
\hline South Dakota & Oil-plugged and abandoned & Oil \\
\hline South Dakota & Oil-producing & Oil \\
\hline South Dakota & Oil-reentered & Oil \\
\hline
\end{tabular}


Appendix C-1. Well classifications for Montana, North Dakota, and South Dakota and the overall well type used for this study.-Continued

$[\geq$, greater than or equal to; $\leq$, less than or equal to; >, greater than]

\begin{tabular}{cll}
\hline \multicolumn{1}{c}{ State } & \multicolumn{1}{c}{ State well classification } & Well type \\
\hline South Dakota & Oil-reservoir monitoring well & Oil \\
South Dakota & Oil-temporarily abandoned & Oil \\
South Dakota & Oil-fee land-plugged and abandoned & Oil \\
South Dakota & Oil-stripper-converted & Oil \\
South Dakota & Oil-stripper-plugged and abandoned & Oil \\
South Dakota & Oil-stripper-producing & Oil \\
South Dakota & Oil-stripper-reentered & Oil \\
South Dakota & Oil-tribal land-plugged and abandoned & Oil \\
South Dakota & Oil-water well-converted & Oil \\
\hline
\end{tabular}




\section{Charting a Course Forward—Identifying Research and Decisionmaking Priorities in the Williston Basin, United States}

By Max Post van der Burg, Karen E. Jenni, Timothy L. Nieman, and James L. Coleman

Chapter D of

Brine Contamination to Aquatic Resources from Oil and Gas Development in the Williston Basin, United States

Edited by Robert A. Gleason and Brian A. Tangen

Scientific Investigations Report 2014-5017 
Suggested citation:

Gleason, R.A., and Tangen, B.A., eds., 2014, Brine contamination to aquatic resources from oil and gas development in the Williston Basin, United States: U.S. Geological Survey Scientific Investigations Report 2014-5017, 127 p.,

http://dx.doi.org/10.3133/sir20145017.

Suggested citation for this chapter:

Post van der Burg, M., Jenni, K.E., Nieman, T.L., Coleman, J.L., 2014, Charting a course forward—identifying research and decisionmaking priorities in the Williston Basin, United States, chap. D of Gleason, R.A., and Tangen, B.A., eds., Brine contamination to aquatic resources from oil and gas development in the Williston Basin, United States: U.S. Geological Survey Scientific Investigations Report 2014-5017, p. 115-127. 


\section{Contents}

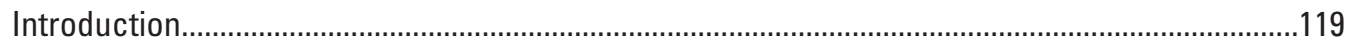

Decision Analysis Workshop ........................................................................................119

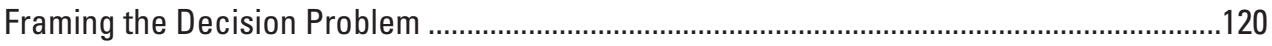

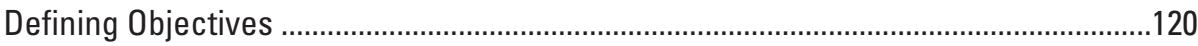

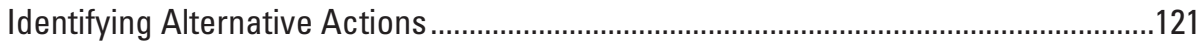

Identifying Key Risks and Uncertainties .....................................................................122

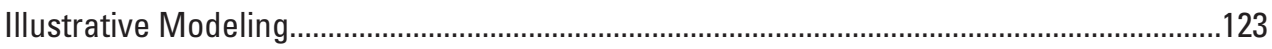

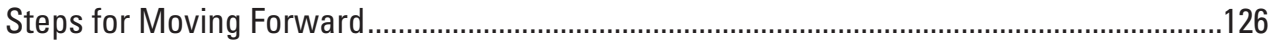

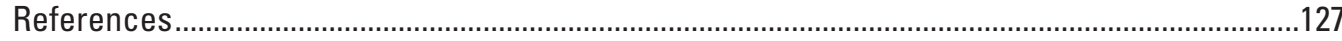

\section{Figures}

D-1. Diagram showing prototype decision model illustrating the relation between decisions, uncertainties, and objectives

D-2. Graph showing simulated landscape containing a small, fresh, seasonal wetland and a large, saline, year-round wetland ....................................................................124

D-3. Graphs showing mean estimates of the effects of well development on wetland water chemistry for two simulated wetlands and three well sites, assuming outwash geology.

D-4. Graph showing effect of site geology on the mean migration rate of a brine plume originating from well pad " $A$ " and affecting the "West" wetland.

D-5. Graph showing uncertainty in the concentration of chlorides in the "West" wetland over time, assuming a well located at pad " $A$ " and outwash geology

D-6. Gaph showing effect of uncertainty in each input variable on uncertainty in the resulting water chemistry in the "West" wetland at three different times, assuming outwash geology

\section{Tables}

D-1. Synthesized table of relevant decisionmakers and the types of decisions made regarding oil and gas development and land management in the Williston Basin .......120

D-2. Strategy table for decision exercise focused on developing best management practices for siting oil wells and monitoring and reclamation requirements................122

D-3. Model parameters and assumptions for Monte Carlo decision model.........................125

D-4. Results of modeling exercise showing the mean impact of well development after 20 years 



\title{
Charting a Course Forward-Identifying Research and Decisionmaking Priorities in the Williston Basin, United States
}

\author{
By Max Post van der Burg, ${ }^{1}$ Karen E. Jenni, ${ }^{2}$ Timothy L. Nieman, ${ }^{3}$ and James L. Coleman ${ }^{1}$
}

\section{Introduction}

The goal of any applied science endeavor should be to provide information that leads to better decisionmaking. This means that applied science performed in the context of land and water-resource management should lead to information that is useful to resource managers as they consider and choose management actions. However, it is often not clear what the best actions are in complex situations. There are many factors that a manager would like to consider when choosing a particular management action:

- What outcomes do I want to achieve?

- Who are the stakeholders in these decisions, and what outcomes do they want to achieve?

- What management actions do I have to choose from?

- What are the likely outcomes of each of those management actions?

- What actions might other stakeholders take that affect management outcomes?

- How do I balance competing objectives when choosing a management action?

- What further information could I collect to better understand the outcomes of different actions, and is that information worth collecting?

For example, in the Williston Basin and Prairie Pothole Region (PPR), wildlife managers are uncertain about the risks posed by oil and gas development activities, such as the likelihood and effect of brine spills on wetlands. Resolving these uncertainties could improve the ability of managers to choose effective management strategies, such as best practices for well siting, to reduce such risks. There are also potential conflicts between the objectives and goals of different

\footnotetext{
${ }^{1}$ U.S. Geological Survey

${ }^{2}$ Insight Decisions, LLC

${ }^{3}$ Decision Applications, Inc.
}

decisionmakers and stakeholders, which might require making tradeoffs.

Decision analysis (DA) is a formal approach for structuring, modeling, and evaluating decisions that contain these types of complexities (Keeney, 1992; Clemen and Reilly, 2001). DA has roots in statistics, economics, operations research, and organizational behavior (Smith and von Winterfeldt, 2004) and provides a foundation for the logical and transparent evaluation of alternatives to help decisionmakers choose actions that are most likely to achieve their goals. Decision analysts use a combination of qualitative structuring approaches and quantitative modeling tools to assess the various components of a decision problem. They use these tools to evaluate the outcomes of different options and make recommendations about which options should be pursued. These recommendations can be sensitive to stakeholder values (that is, the "best" decision may be different from the perspective of different stakeholders) and uncertainties (that is, the best decision may change as new information is gathered [Keeney, 1992; Keeney and Gregory, 2002]). Current scientific studies can provide the information needed to perform such an analysis. One can also use DA to help guide the identification, development, and prioritization of future scientific studies in order to ensure that the collection of information is relevant to a decision problem (Runge and others, 2011).

The previous chapters in this report outline work pertaining to the effects of oil and gas development on aquatic resources. This chapter outlines the first steps toward developing a decision analytic framework for assessing the effects of oil and gas development in the Williston Basin and PPR and for identifying areas where additional applied science work will be most useful to energy- and conservation-related decisionmaking.

\section{Decision Analysis Workshop}

A formal DA workshop was held in Bismarck, North Dakota, from April 18, 2011, to April 21, 2011. Although presented within the context of the work described in previous 
chapters of this report, the overarching context for this workshop was larger: It was to frame the issues surrounding natural resource management and conservation decisionmaking with regard to oil and gas development within the Williston Basin (fig. A-1). The goal of the workshop was to facilitate the development of a concrete example decision problem involving siting oil and gas wells relative to wetlands. The purpose of this analysis was to illustrate how the DA process and modeling can lead to concrete decision recommendations. The workshop was attended by over 30 participants from Federal and State agencies and was facilitated by professional decision analysts.

The participants worked through all the steps of a traditional DA in an abbreviated form. This included first broadly "framing" a set of decisions related to oil and gas development and resource conservation to explore the full scope of relevant issues. The scope of the workshop was narrowed to a smaller set of decisions that were relevant to the U.S. Geological Survey (USGS) project described in chapters B and C of this report. These decisions could be sufficiently modeled during the course of a 4-day workshop to allow participants to understand how the DA modeling process could be used in the future.

\section{Framing the Decision Problem}

The workshop began by discussing and developing an extensive list of relevant decisionmakers in the Williston Basin area and the types of decisions they make. "Relevant" decisionmakers were defined as those who have the ability to affect oil and gas development as well as aquatic resources and the quality of life for people living in the Williston Basin. These decisionmakers were grouped into broad categories (table D-1), and discussions were held as to whether any stakeholder groups or other perspectives were missing. Participants noted that no oil and gas industry representatives were present at the meeting, which limited their ability to thoroughly understand oil and gas development decisions. Additionally, the participants also pointed out that no community development representatives were present, which would have improved their ability to understand community decisions and concerns about oil and gas development.

The workshop then focused on a relatively narrow decision problem or decision context, for which the primary decisionmakers were well-represented among the workshop participants: What best management practices should the U.S. Fish and Wildlife Service (USFWS) recommend for well or well pad development in the vicinity of publicly-managed resources (that is, wetlands)?

\section{Defining Objectives}

Workshop participants developed a prototypical objectives network focused on the more limited scope of the defined decision context. In DA, objectives are objects of value (for example, wildlife populations) and preferences for the direction of value (for example, maximize or minimize). Different stakeholders and decisionmakers may have different objectives, and the consideration of multiple perspectives is a key part of decisionframing. These multiple perspectives ensure that a more robust and comprehensive decision-support model can be developed (Keeney and Raiffa, 1976; Keeney, 1992). This broader perspective is especially useful for agencies or individuals who are primarily interested in identifying what applied science work will be useful to a range of stakeholders.

Participants were divided into one of two hypothetical decisionmaker groups: oil and gas companies and wildlife managers, specifically USFWS managers. Each group

Table D-1. Synthesized table of relevant decisionmakers and the types of decisions made regarding oil and gas development and land management in the Williston Basin.

\begin{tabular}{|c|c|}
\hline Decisionmakers & Decision types \\
\hline Oil Industry & $\begin{array}{l}\text { Lease acquisition (where to develop) } \\
\text { Well development (where, when, and how) } \\
\text { Operations (hydraulic fracturing, water disposal) }\end{array}$ \\
\hline $\begin{array}{l}\text { Land and mineral owners } \\
\text { (including agricultural entities) }\end{array}$ & $\begin{array}{l}\text { Whether to lease and under what conditions } \\
\text { What activities to allow on their lands } \\
\text { What activities to conduct given development (for example, cropping choices) }\end{array}$ \\
\hline $\begin{array}{l}\text { Land and resource management agencies } \\
\text { (for example, U.S. Fish and Wildlife Service, } \\
\text { National Park Service, private landowners) }\end{array}$ & $\begin{array}{l}\text { Recommendations/consultation on well development on or near managed resources } \\
\text { Management of any adverse impacts from development on those resources }\end{array}$ \\
\hline
\end{tabular}


developed a separate list of objectives. After discussion of the similarities and differences between the two perspectives, an integrated set of five main objectives was created. These main objectives contribute to an overall goal of maximizing the net benefits of oil and gas development. Each of these objectives could be further defined by more detailed subobjectives, but the workshop did not attempt to fully define all of the possible subobjectives. There were five main objectives identified:

1. Maximize sustainability of habitats for species of interest. Here the decisionmakers and stakeholders are interested in ensuring that habitat is capable of supporting specific populations and remains resilient to frequent disturbances and fragmentation (all of which were identified as potential subobjectives). This objective was identified as being of interest to both the oil and gas industry and the USFWS.

2. Minimize adverse effects of well development. Well development affects more than just wildlife habitat. The oil and gas industry and wildlife managers would like to minimize the potential negative environmental effects of development to air quality, water quality, and aquatic and terrestrial habitats. Likewise, both groups would like to maximize the safety of oil workers and minimize the time it takes to complete a project.

3. Maximize the economic benefits from well development. The oil and gas industry generates economic benefits for local communities and the State by creating jobs, generating revenue, and paying taxes. Workshop participants taking the oil and gas industry perspective identified several potential subobjectives for increasing economic benefits, including reducing operating costs and taking advantage of new well development opportunities.

4. Minimize conflict between stakeholders. Workshop participants identified a number of areas of conflict because of the current level of development associated with the Bakken Formation and additional conflicts that have occurred during previous oil "booms" in the region. All stakeholders are likely to benefit from minimizing conflict. Some contributors to minimizing conflict could include minimizing the regulatory burden on oil and gas companies, maximizing the simplicity of the process needed to site a new well, and minimizing the number of changes in the regulatory policies for companies. Likewise, maximizing communication between managers, regulatory agencies, and industry representatives, as well as maximizing the sensitivity of the industry to local community issues could help minimize conflict.

5. Maximize accountability of industry for adverse effects. Workshop participants taking the perspective of wildlife managers identified holding oil and gas companies accountable as a key objective. Specifically, if adverse effects do occur, they would want to maximize how much responsibility companies should take for mitigating and remediating wetlands negatively affected by well development (for example, brine spills). Participants noted that this objective is likely to be in conflict with the potential subobjective of minimizing the regulatory burden as a means for minimizing conflict discussed above.

The workshop did not explicitly define comprehensive subobjectives or specific measureable attributes for any of these objectives, as this was only a preliminary exercise. Measurable attributes refer to quantitative measures of the consequences of actions in terms of the effects on objectives (Keeney, 1992; Clemen and Reilly, 2001). Any extensions of this workshop or detailed evaluation and comparison of alternatives would require the development of such measureable attributes.

\section{Identifying Alternative Actions}

The workshop participants initially identified a broad range of decisionmakers and types of decisions regarding oil and gas development and resource management. The decision context was narrowed for the remainder of the workshop in order to illustrate all the steps of a DA process. It is important to recognize that decision "types" often include multiple individual decisions, and multiple alternative actions are possible for each of those individual decisions. This DA exercise was focused on the individual decision types that participants felt were likely to be part of any best management practice for locating well pads and the handling and disposal of produced waters. Specifically, best management practices would likely include:

- Well pad location;

- Size, type, and number of wells;

- Pit design, including pit length;

- Produced waters disposal;

- Development timing;

- Infrastructure design (locations, structure);

- Road network design;

- Reclamation requirements;

- Baseline and monitoring requirements; and

- Documentation requirements.

There may be many different options or alternatives for any of these decisions. Thus, rather than look at every possible combination of decision and alternative, a "strategy table" was developed (table D-2) to illustrate how multiple options could be organized into a set of coherent alternatives for a best management practice.

Decision types and the specific options for each of those decision types are listed in table D-2. An option for a best management practice can be defined by selecting one item 
Table D-2. Strategy table for decision exercise focused on developing best management practices for siting oil wells and monitoring and reclamation requirements.

[Alternatives were not specified for all decision types (for example, timing), but all types were retained in the table because they were considered important considerations in well siting. --, no alternative specified]

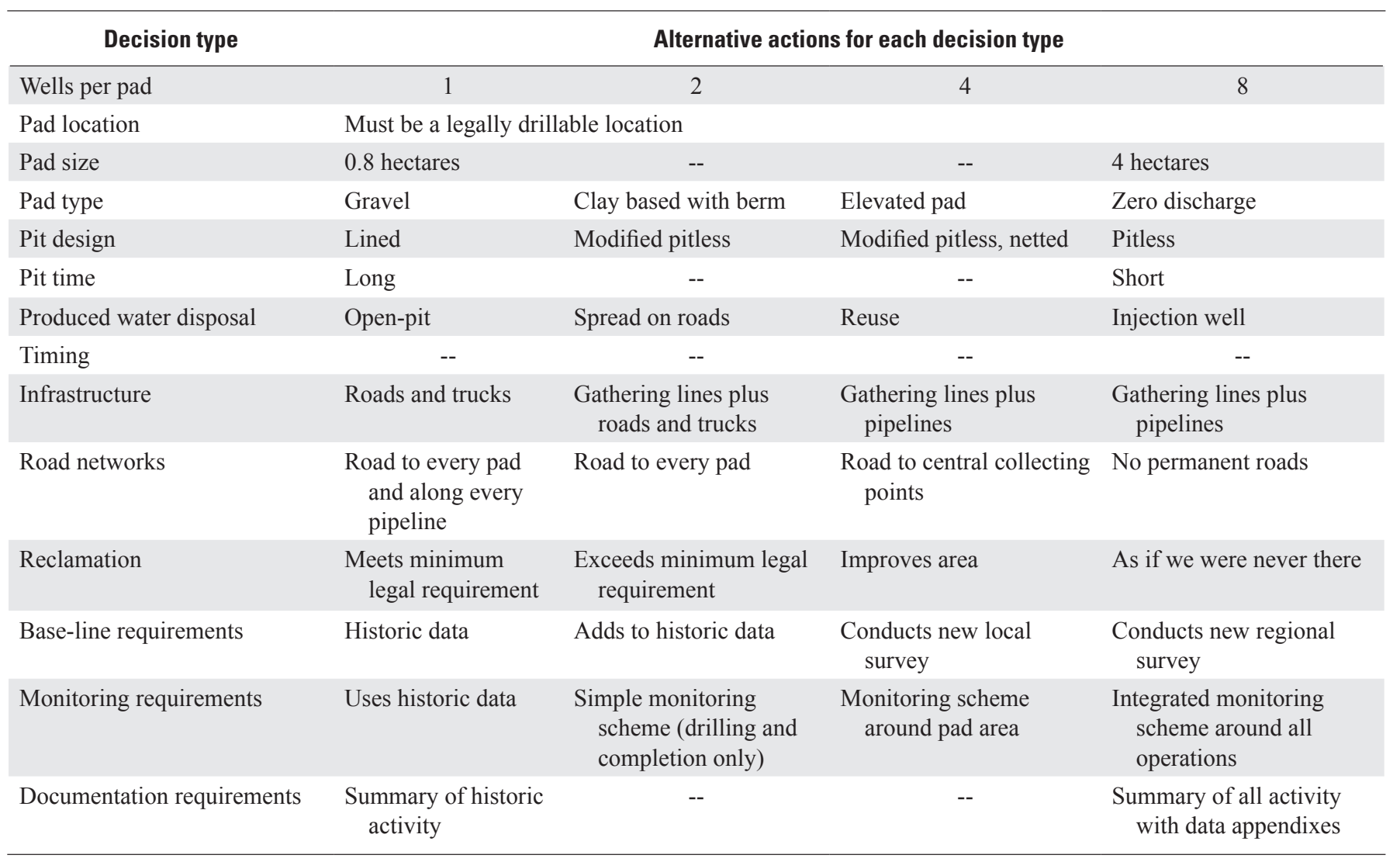

from each row. For example, one option for a best management practice strategy would be four wells per pad on 4-hectare gravel pads in a legally drillable location, pitless design with injection wells for disposal of produced waters, exclusive use of roads and trucks to service the well pad, legally required baseline and monitoring requirements only, reclamation requirements to leave the area better than it was before the well, and extensive documentation required. Many other potential best management practice strategies could be developed by selecting different options for each individual decision represented in the table. Participants recognized that oil and gas company participation in future modeling efforts would greatly facilitate the definition of realistic alternatives for best management practices.

\section{Identifying Key Risks and Uncertainties}

Decision alternatives within a DA framework are evaluated based on how well they meet the various stakeholder objectives, but the ability of those decisions to meet the stated objectives may be affected to some degree by potential negative events that occur with some frequency (expressed as risk).
The ability to estimate the effects of the decision alternatives is affected by the degree of knowledge about a variety of factors (uncertainties) that influence the stated objective. In relation to oil and gas production, one of the key risks is the likelihood of a brine spill during well operation, and some of the key uncertainties have to do with the potential effects of the spill on nearby wetlands. The probability of a brine spill varies based on some of the decision options, such as pit design, pit type, and various well-site operations. Other factors that also can influence how a brine spill will affect nearby wetlands include groundwater flow, the chemistry of the spill, and water chemistry of the wetland. Needless to say, the understanding of these factors is incomplete.

Figure D-1 illustrates the prototype conceptual model outlining the relations between the decision options developed during the workshop, uncertainties, and objectives. As with all parts of this analysis, the model is a simplification. Continuing to identify and quantify other risks and uncertanties will be an integral part of further developing the conceptual decision model. By careful identification of these risks and uncertainties, the decision model will provide a tool for assessing which information will provide the most value in making better management decisions. 


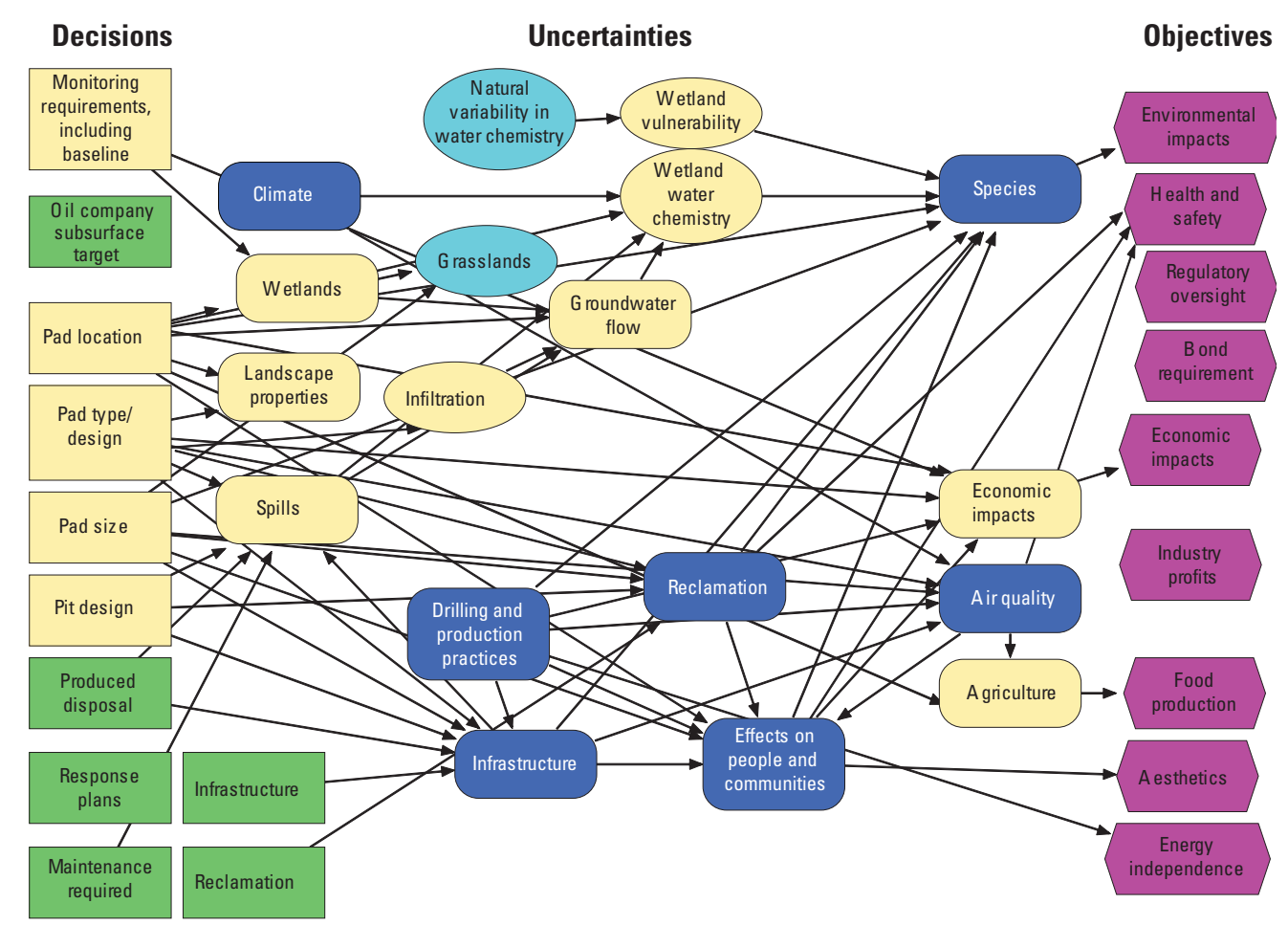

Figure D-1. Prototype decision model illustrating the relation between decisions, uncertainties, and objectives.

\section{Illustrative Modeling}

A simple exercise was used to illustrate how to analyze and compare the effects of alternative decisions regarding best management practices. This hypothetical decision problem focused on choosing one of three possible locations for the placement of a well (fig. D-2). Well placement was to occur in a simulated landscape containing two wetlands of different sizes and initial chloride $\left(\mathrm{Cl}^{-}\right)$concentrations. A Monte Carlo simulation model was used to estimate the outcomes of each well placement strategy. These types of simulations work by making repeated random draws of model parameters from statistical distributions, and then using each randomly generated parameter combination to model phenomena of interest. These distributions were parameterized using expert information. The simulation only considered risks posed to wetlands by wells in terms of contamination from brine spills. Comparing the three locations required estimates of numerous uncertain factors, including the:

- Initial conditions (in terms of water chemistry) for each of the two wetlands;

- Probability of a brine spill, at each location and for each type of well pad considered;

- Size and chemistry of a brine spill, assuming such a spill occurs;
- Probability of the spill being detected, intercepted, and mitigated prior to affecting groundwater, and;

- Dispersion and flow rates of a brine spill over the surface, in the subsurface, and in groundwater.

These estimates, along with other assumptions, allow for the estimation of the $\mathrm{Cl}^{-}$concentration in each wetland over time, assuming there is a well at each of the three locations. This illustrative modeling exercise also included consideration of effects on agriculture (for pad location "B" only) and some of the economic effects of a well at each location. Because this was an illustration, all the necessary model inputs and estimates were developed by using the expert judgment of the workshop participants. The components of the conceptual model that were quantified are represented by the yellow nodes in figure D-1. Very little is known about most of these factors, and these uncertainties are a primary concern throughout the region.

Based on previous experience, participants with knowledge of wetland chemistry provided initial estimates of $\mathrm{Cl}^{-}$ concentrations within each of the two wetlands. The small, fresh wetland ("West") was estimated to have an initial $\mathrm{Cl}^{-}$ concentration between 10 and 60 milligrams per liter $(\mathrm{mg} / \mathrm{L})$. The large, saline wetland ("East") was assumed to have an initial $\mathrm{Cl}^{-}$concentration between 300 and 1,200 mg/L (fig. D-3). 


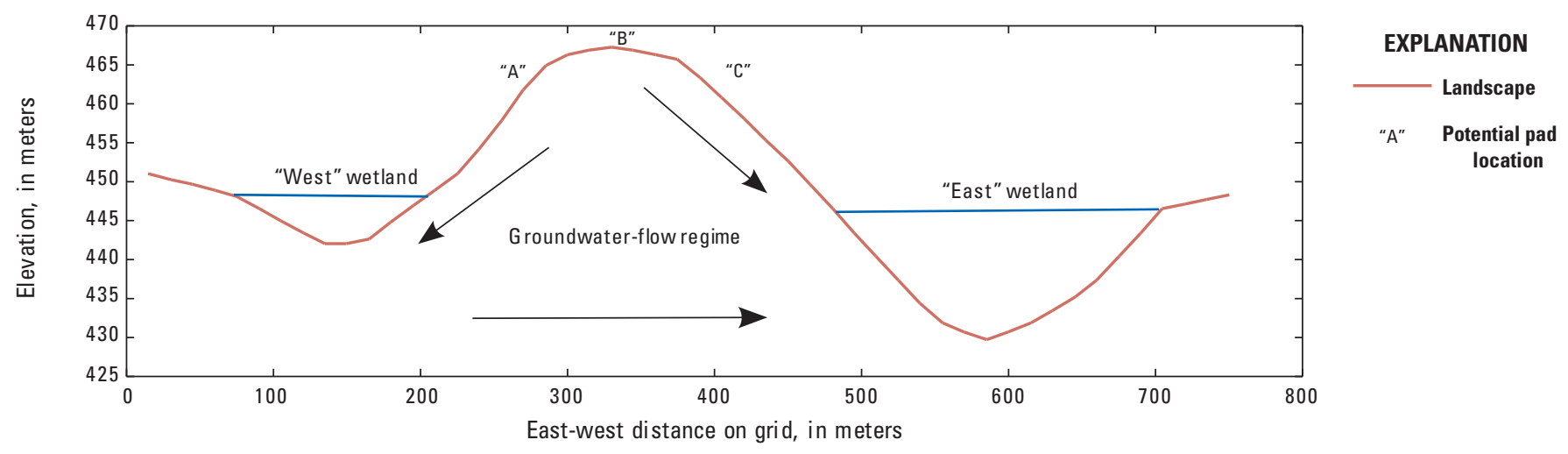

Figure D-2. Simulated landscape containing a small, fresh, seasonal wetland ("West") and a large, saline, year-round wetland (“East)".

Workshop participants first defined a brine spill as being over 4 liters (L), and then estimated that there was a 95-percent chance of a spill or leak of more than $4 \mathrm{~L}$ for each year a well was in operation. There was uncertainty about the total magnitude and the chemistry of spills, which were represented with subjective probability distributions (table D-3). The estimated total annual volume of brine spilled from a single well was between about 400 and 7,500 L, with a median estimate of 2,250 L. The $\mathrm{Cl}^{-}$concentration of the spill was estimated to

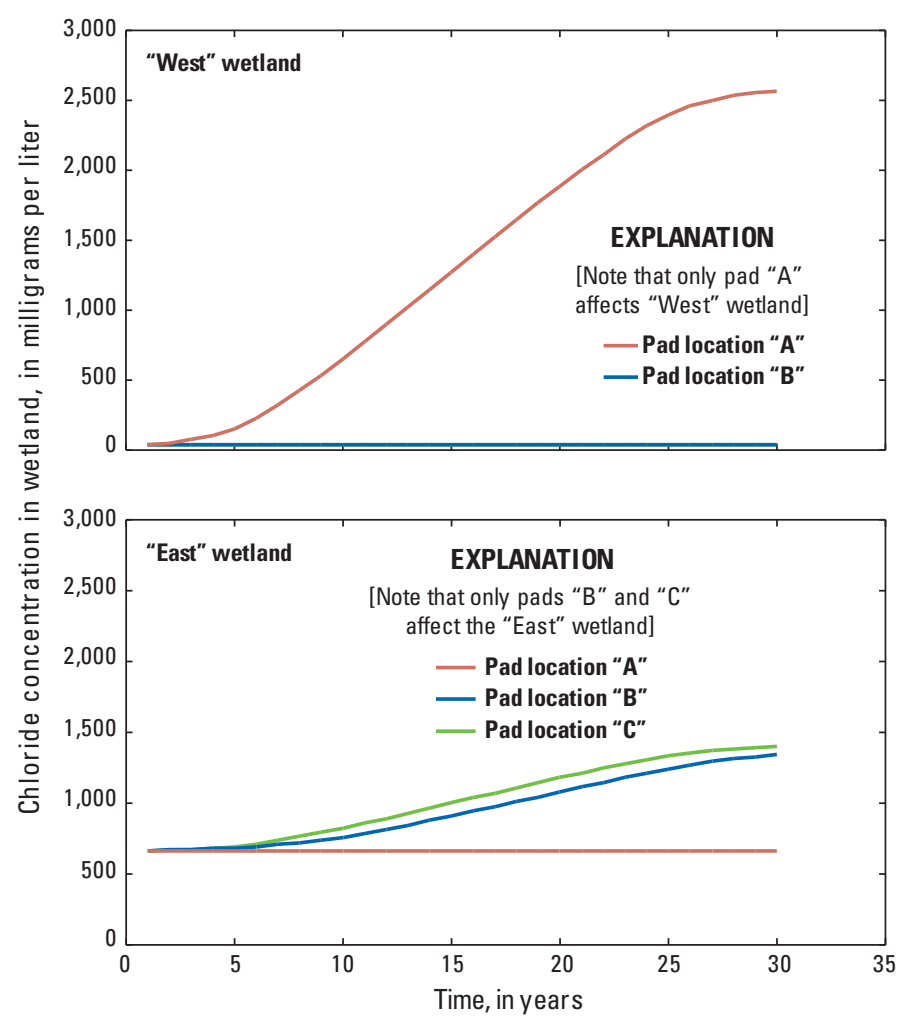

Figure D-3. Mean estimates of the effects of well development on wetland water chemistry (chloride concentration) for two simulated wetlands ("West" and "East") and three well sites, assuming outwash geology. be between a minimum of 60,000 and a maximum of 255,000 $\mathrm{mg} / \mathrm{L}$, with a median estimate of $175,000 \mathrm{mg} / \mathrm{L}$. This latter estimate was informed by the work described in chapter B of this report on the $\mathrm{Cl}^{-}$concentrations in produced waters from the Bakken Formation.

Not all spills or leaks will necessarily lead to brine contamination of wetlands; some will be detected and intercepted when they occur. Participants assumed that between 5 percent and 95 percent of spills could actually be intercepted, which reflects a high degree of uncertainty. For brine spills that reach the shallow groundwater, both the groundwater-flow rate and the rate at which the brine contamination disperses within the groundwater affect the timing and degree of effect on the wetlands. Groundwater-flow rates in the region differ considerably based on the near-surface geologic deposits, with much lower flow rates in glacial till than in outwash. This illustration included till and outwash as potential scenarios and included uncertainty in the groundwater-flow rates for each (table D-3). Lastly, a simple approximation for dispersion of the $\mathrm{Cl}^{-}$plume at the wetland was used along with an assumption that $\mathrm{Cl}^{-}$ concentrations would increase over the first 5 years after the initial arrival at the wetland and then would decline over the following 10 years.

Using these estimates and assumptions, the effects of contamination to the two wetlands were calculated for each of the three well locations. A well at pad "A" affected only the "West" wetland, while wells at pads "B" or "C" affected the "East" wetland (fig. D-2). The calculations show that the effect of a well at pad "A" on the "West" wetland was much greater than the effect of a well at pads "B" or "C" on the "East" wetland (fig. D-3). This was because of the smaller size and lower initial $\mathrm{Cl}^{-}$concentration of the "West" wetland, which means a spill of similar size and chemistry from well pad " $A$ " would have a greater effect on wetland water chemistry than from well pads "B" or "C". Figure D-4 shows the influence of site geology on the resulting wetland water chemistry, with till soils greatly slowing the rate at which the $\mathrm{Cl}^{-}$plume contaminates the wetland.

Figures D-3 and D- 4 show only mean values; the degree of uncertainty regarding the effects of these hypothetical wells on wetland water chemistry is of equal interest. Figure D-5 
Table D-3. Model parameters and assumptions for Monte Carlo decision model.

\begin{tabular}{ll}
\hline \multicolumn{1}{c}{ Parameters } & Assumptions \\
\hline Size of spill, in liters per year & Log-normal distribution with median $=2,250$ and standard deviation $=2$ \\
Chemistry of spill, in milligrams per liter & Log-normal distribution with median $=175,000$ and standard deviation $=2$ \\
Groundwater-flow rate in outwash sites, in meters per year & Triangular distribution with minimum $=3$, mode $=30$, maximum $=150$ \\
Groundwater-flow rate in till sites, in meters per year & Triangular distribution with minimum $=0.03$, mode $=0.6$, maximum $=5.7$ \\
Local communities & Decisions about how to manage the "boom" \\
\hline
\end{tabular}

demonstrates the uncertainty in the water chemistry of the "West" wetland given a well at pad location " $\mathrm{A}$ " when it is located in a glacial outwash deposit. Each line in figure D-5 represents a probability band; the top line represents the $95^{\text {th }}$ percentile estimate and the bottom line represents the $5^{\text {th }}$ percentile estimate. This graph suggests that given all of the uncertainties in the input parameters, there is a 90-percent con-

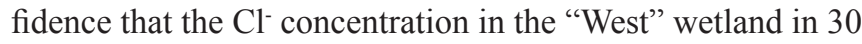
years will be between 500 and $5,700 \mathrm{mg} / \mathrm{L}$, given a well at pad "A" with near-surface outwash deposits.

One of the benefits of this modeling approach is that it provides the ability to show the relative importance of each of the uncertainties in the model inputs on the uncertainty in output. The relation between uncertain inputs and outputs for the workshop simulations is represented with an "importance diagram" (fig. D-6). Each of the inputs is shown on the vertical axis, and the length of the bar shows the correlation between the uncertainty in that value and the resulting uncertainty in the $\mathrm{Cl}^{-}$concentration in the "West" wetland. The highest correlation is for the proportion of the spill volume that is intercepted, which was also the most uncertain value. While that factor is an important contributor to the uncertainty in the $\mathrm{Cl}^{-}$concentration in the "West" wetland, the importance of the other factors varies over time. Uncertainty about the

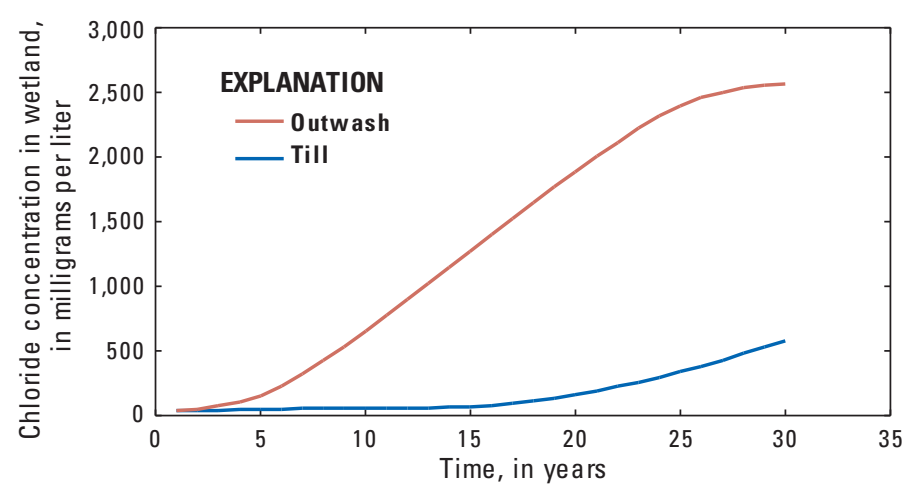

Figure D-4. Effect of site geology on the mean migration rate of a brine plume originating from well pad " $A$ " and affecting the "West" wetland. groundwater-flow rate and about the baseline chemistry of the wetland, for example, are important determinants of wetland water chemistry in year 5 (the fifth year after well installation); however, by year 30, both are much less important.

This type of analysis can be used to help prioritize research areas, if the goal is to have a better understanding of particular outputs of interest. With regard to the workshop exercise, improved understanding of (or better control over) the ability to detect and intercept spills before they reach groundwater would greatly decrease the expected magnitude and the uncertainty about wetland contamination from a well at a particular location. Additionally, improved understanding of brine chemistry and the size of the wetlands potentially affected would improve understanding of the magnitude of wetland contamination more than reducing uncertainty about the size of the spills or the baseline water chemistry of the potentially affected wetlands.

Participants considered additional effects of well development on some of the other objectives identified during the workshop as a final step in this illustrative modeling exercise. Specifically, estimates were made of expected State tax revenues based on simple assumptions about well production and tax rates over time. The potential higher costs for installing a well pad on a slope (locations " $\mathrm{A}$ " or " $\mathrm{C}$ ") compared to a flat location (location "B") and estimated possible effects on farm profits also were considered. All of these simple estimates were made without consideration of uncertainty in order to illustrate the tradeoffs that could be considered in the recommendation of well pad locations.

Table D-4 contains the results of the modeling exercise and illustrates these tradeoffs. Pad "A" clearly has the largest negative effect on the "West" wetland, while pad "B" had a comparatively lower effect in terms of brine spills and similar tax revenues when compared with "A"; pad "B" had a negative effect on farm income because the well was sited on agricultural land. Pad " $\mathrm{C}$ " was similar to pad " $\mathrm{B}$ " in terms of effects on water chemistry, was a more expensive location, but had no effect on farm income. While the workshop did not explicitly illustrate methods for assessing tradeoffs in a multiobjective DA, this last comparison shows how adding more components to the problem can make the analysis more complex and informative. 


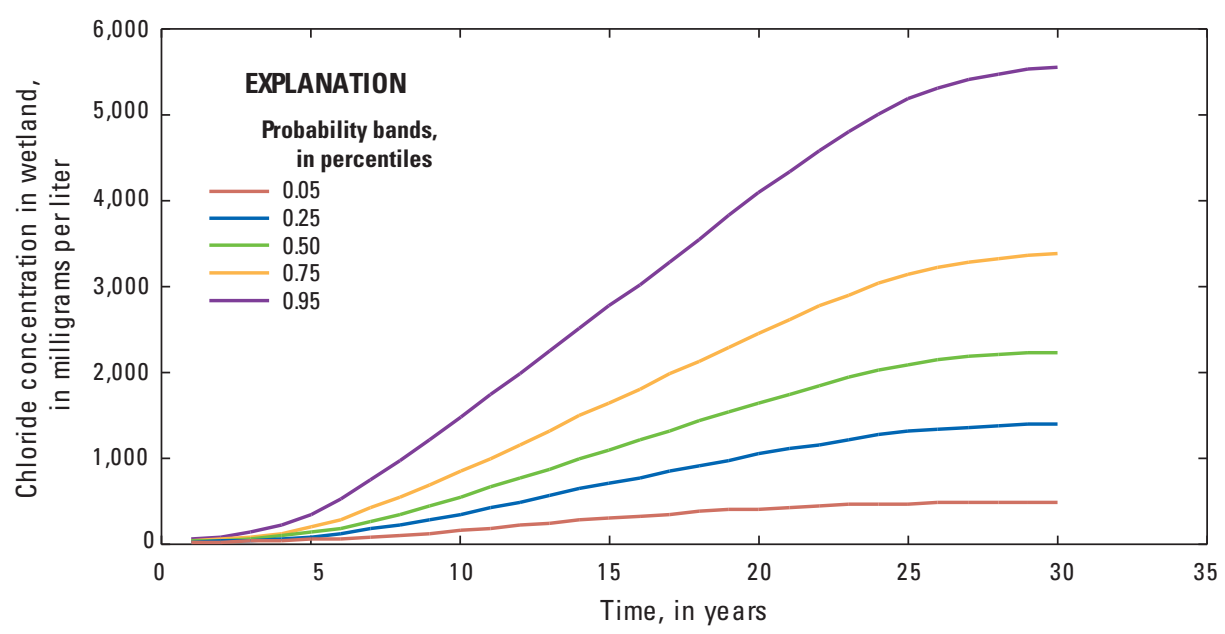

Figure D-5. Uncertainty in the concentration of chlorides in the "West" wetland over time, assuming a well located at pad "A" and outwash geology.

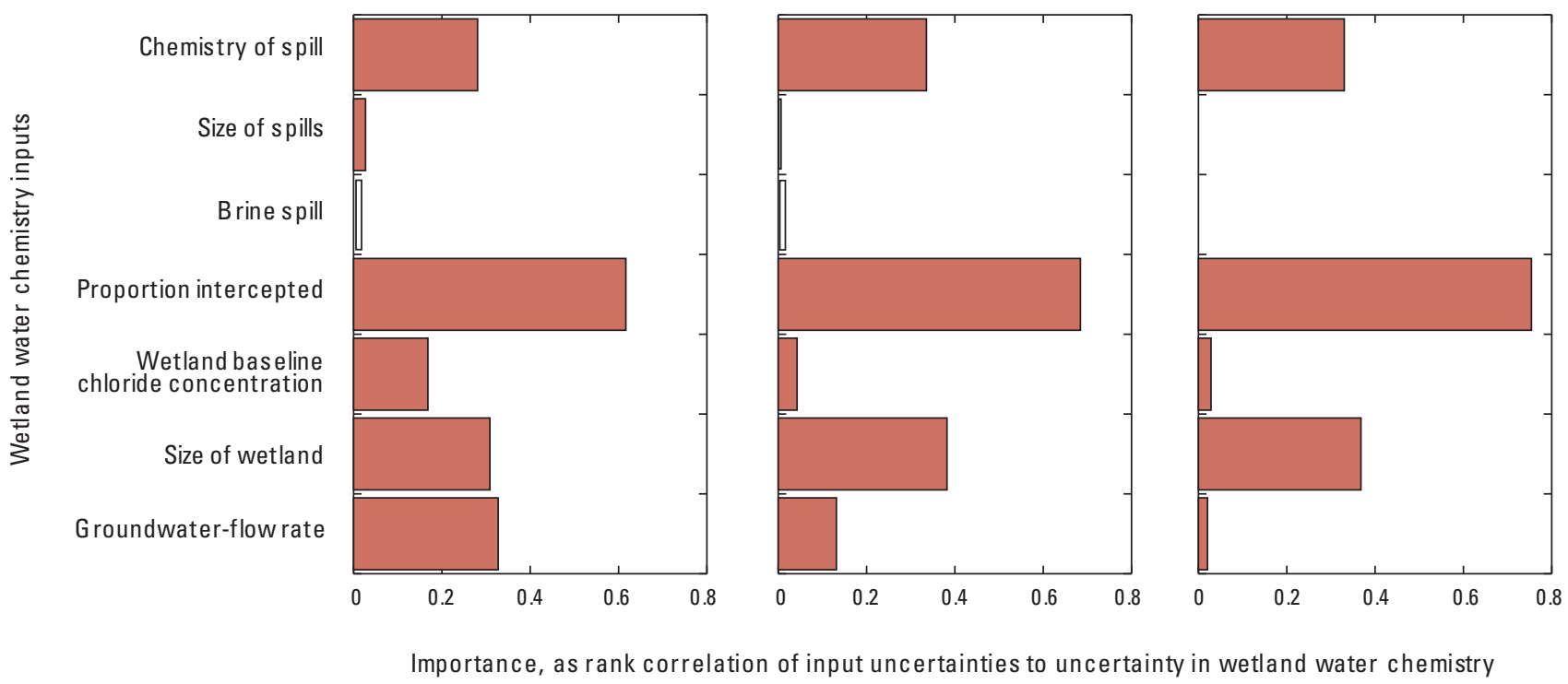

Figure D-6. Effect of uncertainty in each input variable on uncertainty in the resulting water chemistry in the "West" wetland at three different times, assuming outwash geology.

\section{Steps for Moving Forward}

The main focus of the analysis presented in this chapter was simplified to only include two of the stakeholders (USFWS managers and the oil and gas industry) and wellby-well effects on two individual wetlands. It may be useful to expand this framework so that it can be used by multiple stakeholders to evaluate a broader array of decisions and identify key areas of research that would be most valuable across a range of decisions. The end goal is to build a model that can be used by stakeholders to assess alternative development decisions within a broader geographic area. Additionally, this model would account for the cumulative effects of oil and gas well development in the area and provide a basis for identifying and prioritizing applied science activities. A list of possible next steps was developed to accomplish this goal, and challenges were identified that could arise as the framework and model are extended.
1. Include perspectives from other relevant stakeholders. While the workshop participants and facilitators made an effort to include the perspective of the oil and gas industry, more needs to be done to work more directly with industry to accurately represent that perspective. Likewise, the perspectives of local communities and private landowners need to be added to the framework. The current model structure will need to be reviewed with these additional stakeholders to identify missing elements as well as future patterns of oil and gas development. However, drawing these stakeholders together may prove difficult and require discussions with individual groups instead of larger workshops.

2. Define the geographic scope. A challenge for extending this modeling effort is to define a useful geographic scope as the example focused only on a single well pad and its effects on a single wetland. A scale needs to be chosen 
Table D-4. Results of modeling exercise showing the mean impact of well development after 20 years (assuming outwash geology).

[mg/L, milligrams per liter; \$, United States dollars]

\begin{tabular}{|c|c|c|c|}
\hline Output & $\begin{array}{c}\text { Pad "A" } \\
\text { "West" wetland }\end{array}$ & $\begin{array}{c}\text { Pad "B" } \\
\text { "East" wetland }\end{array}$ & $\begin{array}{c}\text { Pad "C" } \\
\text { "East" wetland }\end{array}$ \\
\hline Chloride concentration, $\mathrm{mg} / \mathrm{L}$ & 1,910 & 1,079 & 1,179 \\
\hline Change in chloride concentration, $\mathrm{mg} / \mathrm{L}$ & $+1,876$ & +412 & +512 \\
\hline Industry added cost, $\$$ & 3,300 & 0 & 3,300 \\
\hline Lost farm income, \$ & 0 & 20,000 & 0 \\
\hline Added tax revenue, $\$$ & 1.6 million & 1.6 million & 1.6 million \\
\hline Jobs created, in man-years & 23 & 23 & 23 \\
\hline
\end{tabular}

that is large enough to allow for comparisons between alternative development scenarios but small enough to model potential effects with relevant detail to maximize the utility of the modeling framework.

3. Define the scale of oil and gas development. The relevant scale of oil and gas development needs to be considered in addition to defining a geographic scope for the model. For example, it may be more useful to focus effort on the cumulative effects of multiple wells rather than well-bywell effects throughout the region. However, it is possible that the most important factors to stakeholders regarding cumulative effects of different development patterns may be less than the environmental factors considered and more than socioeconomic responses to development.

4. Consider alternative strategies. The main scope of this workshop was analyzing decisions about best management practices and their effects on nearby wetlands. This focus was targeting the oil and gas well development process. But another set of strategies to consider are decisions about remediation postdevelopment. This would not be as focused on the immediate effects of development, but rather on what the best strategies are for addressing postdevelopment problems. Considering immediate effects, potential spill effects, and remediation options would allow one to look at tradeoffs between lessening immediate effects to a site during well installation relative to future remediation of the site after the well is shut in, or some combination of the two.

5. Assess the value of information. The ultimate goal of this exercise is to provide decisionmakers with a framework that can be used to prioritize management actions and identify science and information needed to improve management. Therefore, there is a need to identify the current state of information related to this problem and be efficient in acquiring new information. A more robust value-of-information analysis (Clemen and Reilly, 2001) than illustrated above could be useful in identifying the most significant uncertainties and where decisionmakers stand to gain the most from new studies associated with this problem.

\section{References}

Clemen, R.T., and Reilly, T., 2001, Making hard decisions: Pacific Grove, Calif., Duxbury, 733 p.

Keeney, R.L., 1992, Value-focused thinking - A path to creative decisionmaking: Cambridge, Mass., Harvard University Press, 416 p.

Keeney, R.L., and Gregory, R.S., 2002, Making smarter environmental management decisions: Journal of the American Water Resources Association, v. 38, p. 1601-1612.

Keeney, R.L., and Raiffa, H., 1976, Decisions with multiple objectives-Preferences and value tradeoffs: New York, N.Y., John Wiley and Sons, 569 p.

Runge, M.C., Converse, S.J., and Lyons, J.E., 2011, Which uncertainty?-Using expert elicitation and expected value of information to design an adaptive program: Biological Conservation, v. 144, p. 1214-1223.

Smith, J.E., and von Winterfeldt, D., 2004, Decision analysis in management science: Management Science, v. 50, p. 561-574. 
Publishing support provided by:

Lafayette and Rolla Publishing Service Centers

For more information concerning this publication, contact: Director, USGS Northern Prairie Wildlife Research Center 8711 37th Street Southeast

Jamestown, North Dakota 58401

(701) 253-5553

Or visit the Northern Prairie Wildlife Research Center Web site at: http://npwrc.usgs.gov/ 





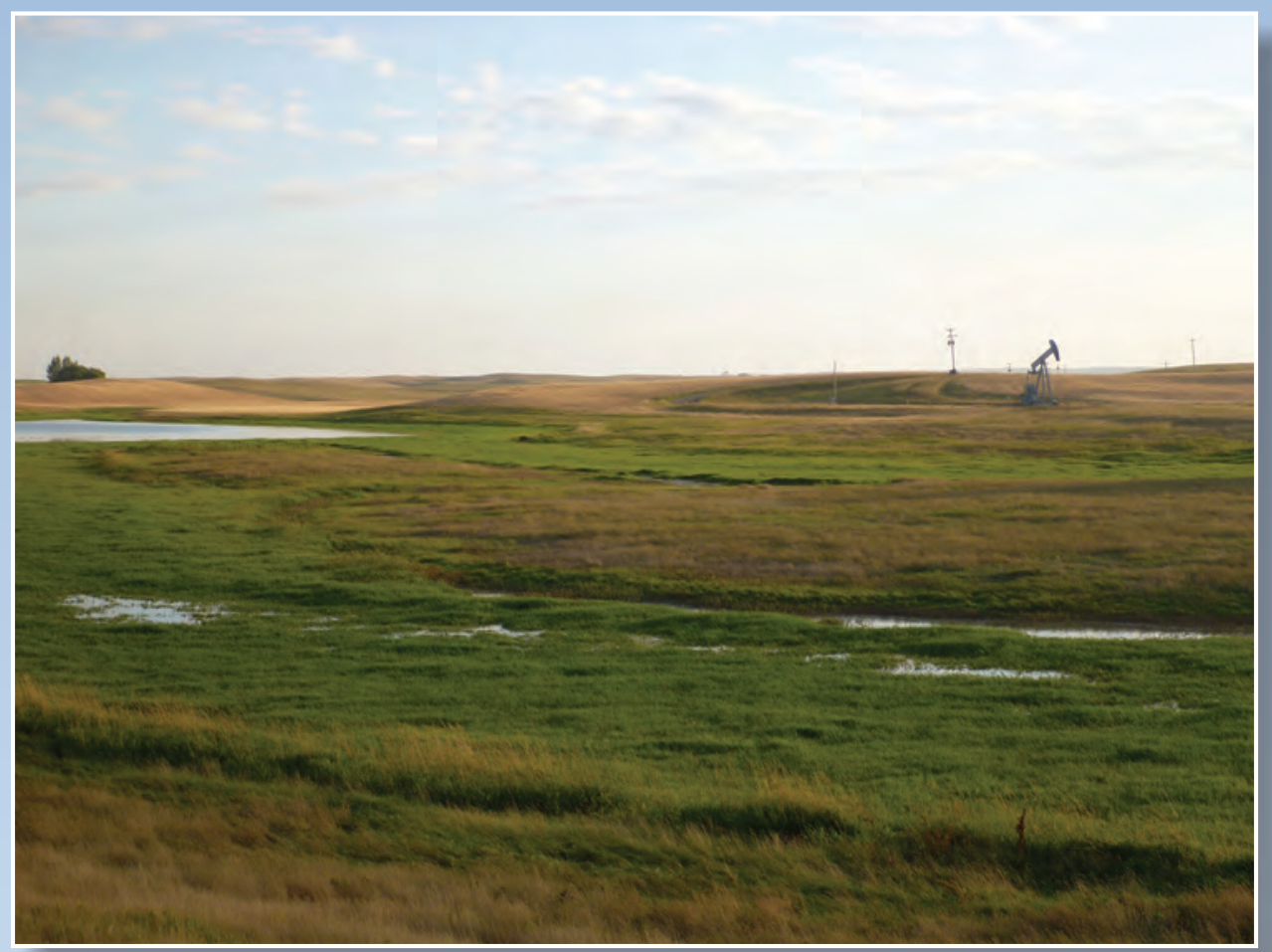

ISBN 778-1-4l]3-3782-4 